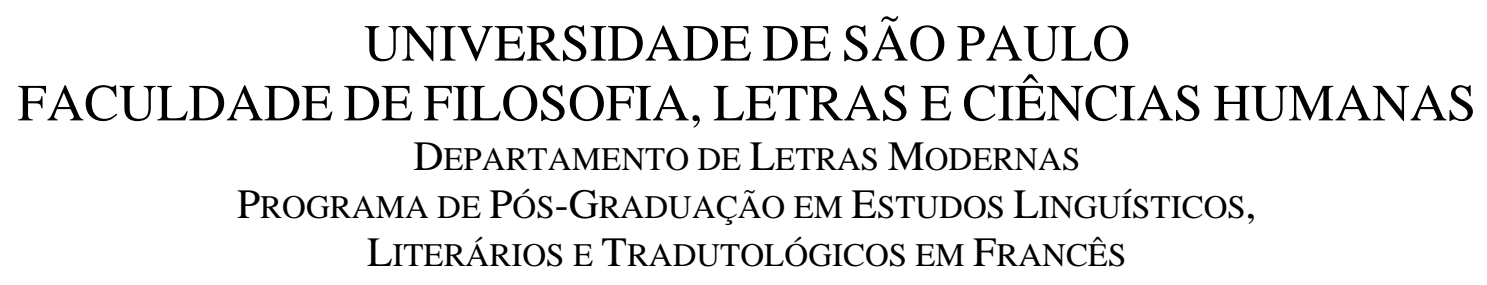

CAROLINA AUGUSTO MESSIAS

\title{
A biblioteca caleidoscópica: um modo de ler La Vie mode d'emploi e Bouvard et Pécuchet
}

(VERSÃO CORRIGIDA)

São Paulo

2012 


\section{A biblioteca caleidoscópica: um modo de ler La Vie mode d'emploi e Bouvard et Pécuchet}

Dissertação apresentada à

Faculdade de Filosofia, Letras e Ciências Humanas da

Universidade de São Paulo para obtenção do título de Mestre em Letras

Área de Concentração: Estudos Linguísticos, Literários e Tradutológicos em Francês

Orientadora: Prof ${ }^{\mathrm{a}}$. Dr ${ }^{\mathrm{a}}$. Claudia Consuelo Amigo Pino

De acordo:

\section{(VERSÃO CORRIGIDA)}


Autorizo a reprodução e divulgação total ou parcial deste trabalho, por qualquer meio convencional ou eletrônico, para fins de estudo e pesquisa, desde que citada a fonte.

Catalogação na Publicação

Serviço de Biblioteca e Documentação

Faculdade de Filosofia, Letras e Ciências Humanas da Universidade de São Paulo

MESSIAS, Carolina Augusto

A biblioteca caleidoscópica: um modo de ler La Vie mode d'emploi e Bouvard et Pécuchet / Carolina

Augusto MESSIAS ; orientadora Claudia Consuelo Amigo

PINO. - São Paulo, 2012.

$136 \mathrm{f}$.

Dissertação (Mestrado) - Faculdade de Filosofia, Letras e Ciências Humanas da Universidade de São Paulo. Departamento de Letras Modernas. Área de concentração: Estudos Linguísticos, Literários e Tradutológicos em Francês.

1. Biblioteca. 2. Georges Perec (1936-1982). 3. La Vie mode d'emploi. 4. Gustave Flaubert (18211880). 5. Bouvard et Pécuchet. I. PINO, Claudia Consuelo Amigo, orient. II. Título. 
MESSIAS, Carolina Augusto

\section{A biblioteca caleidoscópica: um modo de ler La Vie mode d'emploi e} Bouvard et Pécuchet

Dissertação apresentada à Faculdade de Filosofia, Letras e Ciências Humanas da Universidade de São Paulo para obtenção do título de Mestre em Letras.

Aprovada em:

Banca Examinadora

Prof. Dr.

Instituição:

Julgamento:

Assinatura:

Prof. Dr.

Instituição:

Julgamento:

Assinatura:

Prof. Dr.

Instituição:

Julgamento: Assinatura: 


\section{AGRADECIMENTOS}

À Claudia Amigo Pino, pela amizade, orientação, incentivo a todas as minhas viagens teóricas e porque esta pesquisa também é sua.

A todos do Grupo Criação e Crítica, pela companhia, discussões e projetos que, desde 2006, contribuíram muito para o desenvolvimento desta pesquisa. Agradeço especialmente à Samira Murad, pelas longas conversas no trânsito de volta para casa e por suas leituras e releituras pacientes e incisivas, a Monica Gama, Ana Amelia Coelho e Manlio de Medeiros Speranzini, pelas indicações de livros e caminhos interessantes a percorrer, e a Priscila Pesce, pela ajuda com as imagens que ilustram algumas páginas deste trabalho.

À Ana Maria Alfonso-Goldfarb, por me dar a oportunidade de compartilhar um pouco de sua vida acadêmica antes mesmo de iniciar o trabalho de pesquisa e por me permitir viver entre os livros de sua biblioteca.

À Carla Cavalcanti e Silva, pela generosidade da leitura da primeira fase desta dissertação e pelo incentivo constante. À Verónica Galíndez-Jorge, por suas aulas instigantes e pelas leituras e discussões calorosas de todas as fases deste trabalho. À Marcia Arbex, pela alegria da discussão desta dissertação e por suas preciosas sugestões.

À Luciana A. Schoeps, pelo esmero de sua leitura e pelo diálogo constante de nossas pesquisas, apesar da nossa distância. À Isabela Trazzi, pela amizade desde a Graduação, pelas ideias, alegrias e tensões compartilhadas e pela revisão deste trabalho.

À Capes, pelo apoio financeiro para realização desta pesquisa.

A todos os amigos e familiares que contribuíram com sua paciência e compreensão ao longo de todo esse percurso. Em especial, à Ivy Narde, pela cumplicidade, à Ana Carneiro, pelas “almofadinhas”, à Vilma Guilherme, pelos livros e filmes inspiradores, a Juliana Messias e Marcelo Fontes, por todo apoio, conselho e gestos de amor fraterno, e à Gabriela, que me fez sorrir todos os dias.

Ao André, pela espera paciente e pelo carinho de sempre, por estar presente quando eu não estava, por sonhar junto e por muito mais que ainda vamos viver.

A meus pais, pelo amor incondicional, pelo conforto nas horas difíceis e pela presença constante. A Deus, por me dar a oportunidade de viver essa história junto com vocês. 


\section{RESUMO}

MESSIAS, C. A. A biblioteca caleidoscópica: um modo de ler La Vie mode d'emploi e Bouvard et Pécuchet. 2012. 136 f. Dissertação (Mestrado) - Faculdade de Filosofia, Letras e Ciências Humanas, Universidade de São Paulo, São Paulo, 2012.

Os romances Bouvard et Pécuchet (1881), de Gustave Flaubert, e La Vie mode d'emploi (1978), de Georges Perec, são lidos, nesta dissertação, a partir do tema da biblioteca, que se desdobra (assim como essas obras) em três vias que se entrecruzam: virtual, imaginária e real. As bibliotecas virtuais são construídas a partir de diversos registros e referências intertextuais deixadas por escritores em anotações, cadernos, correspondência, etc., que são tomadas como documentos da gênese de sua escrita. Já as bibliotecas imaginárias são aquelas tematizadas nos livros, ou seja, são encontradas em obras que ficcionalizam o espaço e a dinâmica das bibliotecas. As bibliotecas reais dos escritores, por sua vez, são formadas por volumes que fizeram parte de seu acervo pessoal. Esta pesquisa propõe refletir sobre as práticas de leitura e escrita de Georges Perec e Gustave Flaubert paralelamente à análise das obras La Vie mode d'emploi e Bouvard et Pécuchet. Essa reflexão resulta da observação de alguns vestígios de suas bibliotecas virtuais e "reais” e das relações entre aquelas três faces da biblioteca. Nesse sentido, esta dissertação pretende apresentar diversos arranjos que as múltiplas peças dessa biblioteca caleidoscópica podem formar.

Palavras-chave: Biblioteca, Georges Perec (1936-1982), La Vie mode d'emploi, Gustave Flaubert (1821-1880), Bouvard et Pécuchet, Crítica temática. 


\begin{abstract}
MESSIAS, C. A. The kaleidoscopic library: a way of reading Life: a user's manual and Bouvard and Pécuchet. 2012. 136 f. Dissertação (Mestrado) - Faculdade de Filosofia, Letras e Ciências Humanas, Universidade de São Paulo, São Paulo, 2012.

In this dissertation, Gustave Flaubert's Bouvard and Pécuchet (1881) and Georges Perec’s Life a user's manual (1978) are analyzed through the theme of the library, a theme that has (such as in the novels) three dimensions which interconnect: a virtual, a real and an imaginary one. The virtual dimension of the library is formed by the intertextual references and notes left by the writers in their writing process documents such as their notebooks and letters. The imaginary dimension of the library takes the form of the figuration of the library in the books that fictionalize the space and the dynamics of the library. Finally, the real dimension of the library takes the form of the books that were part of the writers' personal libraries. Because of these three dimensions, this dissertation not only analyses the text of novels but also reflects about Perec's and Flaubert's writing and reading practices. This is possible through the observation of the traces of the virtual and the real dimensions of the library and through the interconnection of three dimensions mentioned. In this sense, this dissertation aims at presenting some of the various arrangements that can be formed by the multiple pieces of this kaleidoscopic theme.
\end{abstract}

Keywords: Library, Georges Perec (1936-1982), Life: a user's manual, Gustave Flaubert (1821-1880), Bouvard and Pécuchet, Thematic criticism. 


\section{RÉSUMÉ}

MESSIAS, C. A. La bibliothèque kaléidoscopique: un mode de lire La Vie mode d'emploi et Bouvard et Pécuchet. 2012. 136 f. Dissertação (Mestrado) - Faculdade de Filosofia, Letras e Ciências Humanas, Universidade de São Paulo, São Paulo, 2012.

Les romans Bouvard et Pécuchet (1881), de Gustave Flaubert, et La Vie mode d'emploi (1978), de Georges Perec, sont lus, dans cette dissertation, à partir du thème de la bibliothèque, qui se dédouble (comme les oeuvres) en trois voies entrecroisées: virtuelle, imaginaire et réelle. Les bibliothèques virtuelles sont composées par plusieurs registres et références intertextuelles laissés par des écrivains dans ses notes, cahiers, correspondance, etc., lesquels sont réunis pour composer les documents de genèse de leurs écritures. Les bibliothèques imaginaires sont thématisées dans les livres, c’est-à-dire, elles sont trouvées dans les oeuvres qui fictionalisent l'espace et la dynamique des bibliothèques. En plus, les bibliothèques réelles des écrivains sont formées par des volumes qui ont fait partie de leurs fonds personnel. Cette recherche propose de réfléchir sur les pratiques de lecture et écriture de Georges Perec et de Gustave Flaubert parallèlement à l'analyse des oeuvres La Vie mode d'emploi et Bouvard et Pécuchet. Cette réflexion provient de l'observation de certains vestiges de leurs bibliothèques virtuelles et “réelles” et des rapports entre ces trois faces de la bibliothèque. Dans ce sens-là, cette dissertation vise à présenter des aspects différents que les multiples pièces de cette bibliothèque kalédoscopique peuvent montrer.

Mots-clés: Bibliothèque, Georges Perec (1936-1982), La Vie mode d'emploi, Gustave Flaubert (1821-1880), Bouvard et Pécuchet, Critique thématique. 


\section{Lista de ilustrações}

Figura 1 (página 34). Exemplo da lista feita por Perec para compor o capítulo 69. Altamont, 4 presente no Cahier de Charges de La Vie mode d'emploi, Paris: CNRS, 1993.

Figura 2 (página 35). Poligrafia do cavalo presente no Cahier de Charges de La Vie mode d'emploi, Paris: CNRS, 1993, p. 40.

Figura 3 (página 75). LVME, p. 319. Chapitre LVI - Escaliers, 8.

Figuras 4a e 4b (página 75). LVME, p. 26. Chapitre II - Beaumont, 1.

Figura 5 (página 86). O bibliotecário, de Arcimboldo. Óleo sobre tela, 97x71 cm. Skoklosters Slott, Bålsta (Stockholm). Imagem disponível em: <http://www.wga.hu/framese.html?/html/a/arcimbol/> Acesso em 19 dez. 2011.

Figura 6 (página 89). A Primavera de 1573, de Arcimboldo, com o diferencial da borda formada por folhas, foi exposta no Louvre/Paris. Há outra versão autógrafa de 1563 exposta no Museo de la Real Academia de San Fernando/Madrid e outra sem data e sem assinatura que pertence a uma coleção de Bayerischen Staatsgemäldesammlungen/Munique. Imagem disponível em: <http://www.wga.hu/frames-e.html?/html/a/arcimbol/> Acesso em 19 dez. 2011. 


\section{Lista de abreviaturas}

Foram mantidas em francês no corpo do texto todas as citações dos romances Bouvard et Pécuchet, de Gustave Flaubert, da edição de Claudine Gothot-Mersch publicada em 2009 pela Gallimard, e La Vie mode d'emploi, de Georges Perec, da edição de 1994 publicada pela Hachette. A fim de facilitar a identificação e a leitura, essas citações vêm acompanhadas das abreviaturas dos títulos de cada romance, conforme a lista abaixo, seguidas do(s) número(s) da(s) página(s) e estão traduzidas para o português em nota de rodapé.

\section{Títulos}

Bouvard et Pécuchet, de Gustave Flaubert

La Vie mode d'emploi, de Georges Perec

\section{Siglas}

$B P$

LVME

As traduções foram feitas a partir do cotejamento com as edições brasileiras: Bouvard $e$ Pécuchet, traduzida por Marina Appenzeller e publicada pela Estação Liberdade em 2007, e A Vida modo de usar, traduzida por Ivo Barroso e publicada pela Companhia das Letras em 2009. Essas edições são indicadas apenas quando há citação literal da tradução. As demais traduções, tanto dos textos de Perec e Flaubert como de outros textos utilizados, caso não façam menção expressa a uma edição em português, são de responsabilidade da autora e visam oferecer ao leitor uma maior fluidez na leitura, sem a pretensão de atingir uma literalidade ou excelência na tradução. 


\section{SUMÁRIO}

Angústia da desordem.

Capítulo 1 - Assombros da biblioteca: modos de ler em relação e moldes de produção

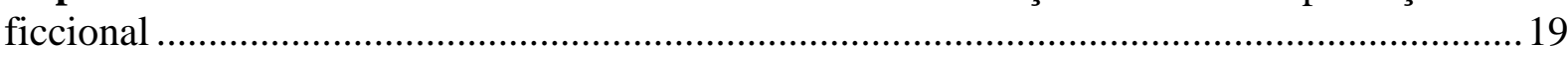

Biblioteca como modo de ler em relação ............................................................................... 19

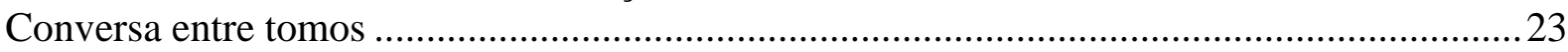

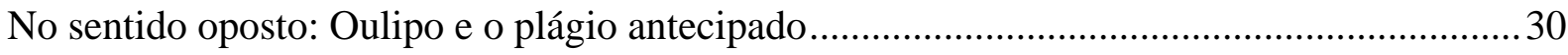

O prédio assombrado de La Vie mode d'emploi: "planta e memorial descritivo” ....................33

Um mundo cheio de livros: o romance envenenado de Flaubert ..............................................42

Leia apenas se quiser se perder (numa biblioteca fantástica) ...................................................45

Capítulo 2 - Os livros-bibliotecas de Flaubert e Perec: bibliotecas, livros e leitores ficcionalizados em Bouvard et Pécuchet e La Vie mode d'emploi............................................53

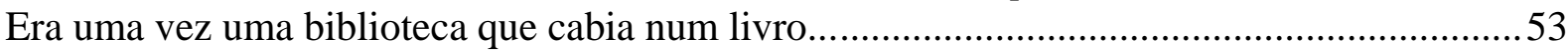

Bouvard e Pécuchet no jardim de saberes que se bifurcam..................................................56

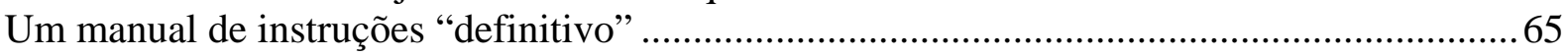

Retalhos de livros e outros detalhes de biblioteca que compõem a Vida ...............................69

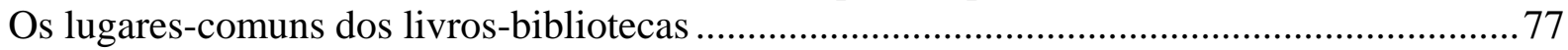

Capítulo 3 - Da relação com os livros à coleção de quinquilharias: listas, descrições e

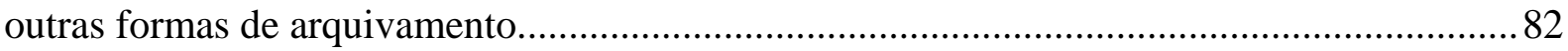

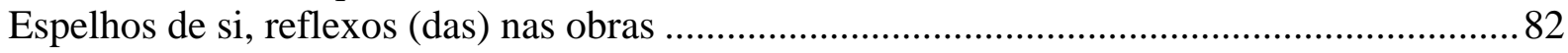

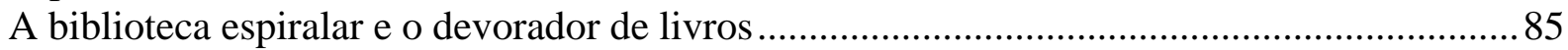

Da biblioteca perecquiana e outros inventários de fantasmas ...............................................93

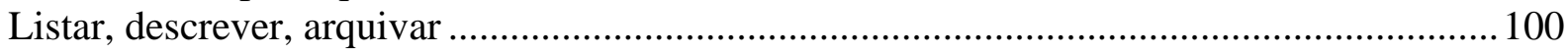

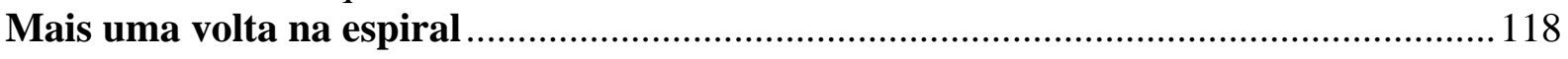

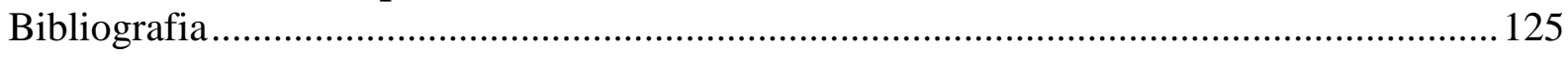




\section{Angústia da desordem}

Estou desempacotando minha biblioteca. Sim, estou. Os livros, portanto, ainda não estão na estante; o suave tédio da ordem ainda não os envolve.

Walter Benjamin

A página em branco é uma estante à espera de livros. Assim como os livros espalhados e encaixotados aguardam um lugar na estante da biblioteca, a página busca incessantemente a tediosa ordem linear das frases. Dispor um livro ao lado de outro é uma escolha tão pessoal quanto escrever uma frase evidenciando o sujeito ou o objeto e demonstra que o ato de classificar os elementos pode ser eternamente provisório.

Universo, vida, labirinto, espaço povoado por fantasmas, quebra-cabeça, etc., muitas são as metáforas criadas para falar sobre esse lugar destinado especialmente aos livros. Um espaço que detém o poder de acolher e rejeitar memórias, que pode ser grande como um edifício repleto de estantes abarrotadas ou breve como uma coleção na prateleira de um cômodo da casa. Difícil de definir e classificar, a biblioteca só poderia instigar uma série de perguntas em seus "frequentadores".

Mas o que dizer das bibliotecas que não ocupam um lugar físico, e sim linhas e entrelinhas de livros? Como ler livros formados por outros livros? Claro que, em princípio, todos os livros são formados por outros (é o que as referências finais costumam denunciar), mas há aqueles livros que ficcionalizam a dinâmica das bibliotecas, que foram escritos com base na reflexão sobre o imaginário desse espaço de relação entre tempos e saberes. É o caso dos romances La Vie mode d'emploi (1978), de Georges Perec (1936-1982), e Bouvard et Pécuchet (1881), livro póstumo de Gustave Flaubert (1832-1880) ${ }^{1}$.

Nesse sentido, esta dissertação busca justificar a escolha de aproximar Perecs de Flauberts, que costumam ser separados espacialmente pela ordem alfabética dos sobrenomes (se a organização fosse feita por nomes próprios, eles não ficariam tão distantes assim...) adotada pelas bibliotecas públicas e institucionais. Como é importante explicitar, logo na desordem do início, as possibilidades de leitura e os limites ${ }^{2}$ desta dissertação, esclareço que a

\footnotetext{
${ }^{1}$ Em algumas ocasiões, utilizarei as siglas $L V M E$ e BP para me referir aos romances La Vie mode d'emploi e Bouvard et Pécuchet, respectivamente.

${ }^{2}$ De acordo com Jean Starobinski (2001b, p. 33-4), “um método especificado define, de alguma forma, uma parte da obra, ou um pedaço pequeno do conjunto que a obra poderia formar com uma certa categoria de elementos circunvizinhos (artísticos, sociais, econômicos, etc.) [...] Seu mérito não é apenas abrir as possibilidades de leitura mas também impor limites". No original: "Une méthode spécifiée définit, en quelque sorte, une section de l'oeuvre, ou une tranche fine de l'ensemble que l'oeuvre pourrait former avec une certain
} 
metodologia aqui utilizada para colocar as obras desses escritores lado a lado na estante da página é temática, ou seja, proponho a leitura de temas suscitados pela relação entre $B P$ e LVME. Logo, adoto aqui a mesma advertência que Starobinski (2001a, p.9) apresenta em julho de 1988 em seu As máscaras da civilização: "Não se espere uma pesquisa sistemática, nem uma história completa. Quis escutar as palavras, analisar estilos. Era preciso proceder por sondagens.”

Um tema é "uma rede de significações, um elemento semântico recorrente de um escritor em uma obra e/ou de uma obra a outra”3 (GENGEMBRE, 1996, p. 23), como figuras, objetos, sentimentos, etc. Em La Conscience Critique (1971), Georges Poulet define a leitura como momento de coincidência da consciência do leitor com a do autor e mostra que não se trata de uma tendência nova, pois pode ser notada já no romantismo europeu, por exemplo, na crítica de Mme. de Staël, “cujo movimento generoso do pensamento admirativo [provocativo] estende logo a se colocar em uníssono ao pensamento admirado” ${ }^{4}$ Emoção e reflexão são os componentes da crítica de Mme. de Staël, segundo Poulet (1971, p. 25), já que ela procura expressar, em seus textos críticos, a admiração que sentiu no ato da leitura. Porém, não se trata de um sentimento isolado ligado a um conhecimento despropositado da obra lida. Poulet (1971, p. 21) adverte que essa admiração “consiste na redescoberta, pela lembrança, da

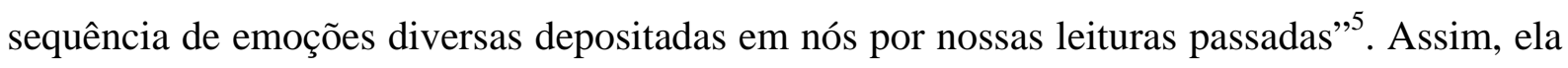
é característica importante da crítica que se debruça sobre temas, estabelecendo relações entre o sujeito-leitor e o que o rodeia ao mesmo tempo em que observa a dinâmica da escrita do texto examinado ${ }^{6}$. Neste ponto, um breve relato de meu percurso de leitura, ligado à

catégorie d'éléments environnants (artistiques, sociaux, économiques, etc.). [...] Son mérite n’est pas seulement d'ouvrir des possibilités de lecture, mais aussi d'imposer des points d'arrêt."

3 "Il faut distinguer la conception élaborée par l’histoire littéraire ou la littérature comparée, autrement dit un motif commun à plusieurs oeuvres, et celle propre à la critique thématique, pour qui un thème est un réseau de significations, un élément sémantique récurrent chez un écrivain dans une oeurve et/ou d'une oeuvre à l'autre. Tout peut donc servir de thème: figure, objet, sentiment, mythe, etc., puisque tout peut être indice de l'être-aumonde de l'écrivain."

4 “Chacun s'y efforce de revivre et de repenser par soi-même les expériences vécues et les idées pensées par d'autres esprits. Cette tendance n'est pas absolument nouvelle. Il est facile d'en apercevoir les origines dans le romantisme européen. [...] Le premier critique français à adopter cette méthode est Mme. de Staël. Critique chez qui le mouvement généreux de la pensée admirative tend aussitôt à se mettre à l'unisson de la pensée admirée." (POULET, 1971, p. 10) Na tradução, optei por não traduzir esprit por espírito ou gênio, pois essas palavras poderiam conduzir a uma interpretação dúbia do trecho devido à sua carga semântica.

5 "La conscience d'un écrivain ne se borne pas à un acte isolé d’admiration. Il consiste en la redécouverte, par le souvenir, de la suite d'émotions diverses deposés en nous par nos lectures passés."

6 “[...] la critique thématique accorde une grande importance à la relation du moi et de ce qui l'entoure.[...] Elle privilégie les catégories de la perception et de la relation (espace, temps, sensations), auxquelles elle confère un usage souvent métaphorique. Enfin, elle examine attentivement la dynamique de l'écriture.” (GENGEMBRE, 1996, p. 24) 
admiração pela obra de Flaubert e Perec, pode ser pertinente para redescobrir a justificativa da pesquisa:

Minha relação com esses escritores surgiu logo na graduação, no curso de Literatura Francesa 1, quando conheci o projeto estético de Perec ligado ao Oulipo e ao diálogo com diversos escritores por meio de citações e jogos de escrita, especificamente no livro Un homme qui dort (1967). O modo como Perec incluía citações de Kafka, Melville e Sartre nesse romance pareceu-me tão incômoda quanto provocativa, pois era a primeira vez, em meu percurso como leitora, que a citação não era colocada como algo acessório, uma referência, ou um dos elementos da composição do texto, mas sim como um procedimento de escrita crucial da poética de um escritor. Além disso, esse mesmo curso propôs aos alunos o desafio de reescrever um texto ficcional após a leitura dos contos de Pascal Quignard (Le nom sur le bout de la langue) e de Jean-Paul Sartre (L'Enfance d'un chef) e do romance já mencionado de Perec. Nesse sentido, a citação revelou-se uma ponte entre a leitura e a escritura e entre o discurso crítico e o ficcional, assim como para Butor, para quem "[...] uma obra é sempre obra coletiva. Aliás, é por essa razão que eu me interesso pelo problema da citação. A citação é o ponto nevrálgico da ligação leitura-escritura, crítica-invenção.” (apud PERRONEMOISÉS, 1978, p. 108)

A partir de então comecei a me interessar pela obra perecquiana e por questões ligadas à reapropriação textual e, sob orientação da Profa. Dra. Claudia Amigo Pino, iniciei a pesquisa de Iniciação Científica ${ }^{7}$ sobre o primeiro romance de Perec, Les choses (1965), que era apresentado como um "romance declaradamente flaubertiano" na contracapa. Nesse trabalho, propus a análise da presença sistemática de outros escritores no romance perecquiano. Em outras palavras, investiguei essa forma de se relacionar com o "fazerescrever” como uma poética da reescritura.

Para isso, refleti mais detidamente sobre a escolha de Flaubert e de L'Éducation sentimentale (1869) como um dos vértices do quadrado construído por Perec em torno de Les choses na conferência "Pouvoirs et limites du romancier français contemporain” (1967), proferida em Warwrick. Nessa ocasião, Perec discorre sobre o papel dos escritores, vale dizer, numa época em que se discutia o Nouveau Roman e a literatura engajada. Além disso, ele apresenta, na mesma conferência, os chamados "modelos” que enquadram seu primeiro

\footnotetext{
${ }^{7}$ Pesquisa intitulada "Georges Perec: uma poética da reescritura”, financiada pela FAPESP de 2007 a 2008.0 artigo "O pesadelo de um Milhão de Coisas", que apresenta o resultado dessa pesquisa, foi publicado pela Revista Criação \& Crítica, Número 3, cujo dossiê é dedicado à narrativa francesa do século XX. Disponível em: http://www.fflch.usp.br/dlm/criacaoecritica/dmdocuments/12CC_N3_CAMessias.pdf. Acesso em 19 jan. 2011.

${ }^{8}$ Cf. a entrevista completa transcrita por Leslie Hill em PEREC, 2003a, p. 76-88.
} 
romance: Antelme, Barthes, Nizan e Flaubert. Por meio da análise de Les choses, observei como Perec trabalhava o foco narrativo e as descrições de forma semelhante ao estilo adotado por Flaubert em sua obra, sobretudo por meio da escolha dos tempos verbais e da acumulação de objetos que parecem ter mais vida que os personagens. Naquele momento, pude entender que a reescritura perecquiana não se limitava a um só livro de Flaubert, mas a todo o repertório flaubertiano. Compreendi então que a reescritura perecquiana não poderia ser analisada apenas pela identificação de citações pontuais, mas sim pela retomada e pela crítica da escritura flaubertiana, ou seja, percebia que, em sua obra ficcional, Perec conseguia, sem ser óbvio ou caricato, fazer o leitor sentir o déjà-lu, abrindo espaço para que, assim como o escritor, o leitor também recriasse a tradição literária, passando do prazer da leitura ao desejo de escritura.

No Mestrado, a percepção de que em Flaubert existia também um trabalho de escrita no sentido de refletir sobre a literatura e sobre o uso de discursos científicos que circulavam em sua época, no interior de sua obra, sobretudo em $B P$, permitiu-me relacionar as práticas de escrita e de leitura desse escritor com as de Perec, sobretudo em LVME. Nesse sentido, pude ler também em Flaubert algo que só enfocava em Perec até então: a presença de um discurso crítico-ficcional, mesmo que mais concentrada em sua obra inacabada. Segundo Leyla Perrone-Moisés (1978, p. 11-12):

Desde o fim do séc. XIX, os escritores revelaram uma acentuada tendência à autocrítica. Desde então, a obra literária tem se tornado, cada vez mais, uma reflexão sobre a literatura, uma linguagem que contém sua própria metalinguagem (Lautréamont, Mallarmé, Joyce). Esta "crítica interna”, realizada no interior das próprias obras, entrou em concorrência com a “crítica externa”, exercida pelos leitores-críticos. [...] Assistimos então ao aparecimento de um novo tipo de discurso literário, aflorando no lugar anteriormente ocupado pelo discurso crítico: um discurso crítico-inventivo no qual se fundem as características do discurso crítico e do discurso poético, até este momento considerados como inconciliáveis, a não ser num nível puramente estilístico.

Essa reflexão sobre as questões relacionadas à crítica da literatura, à linguagem ficcional aliada à presença do trabalho com discursos científicos e com a linguagem do cotidiano e à caracterização de personagens leitores e pesquisadores nos romances $L V M E$ e BP suscitou o tema da biblioteca em minha leitura. Assim como Starobinski (2001a, p. 162230), em “O remédio no mal: o pensamento de Rousseau”, parte do relato da doença de Rousseau para percorrer temas correlatos na obra rousseauniana, como curável, incurável, veneno, remédio, paliativo, entre outros, neste trabalho também parto de um tema, o da 
biblioteca, que se desdobrará ${ }^{9}$ (assim como as obras). Como se formasse três voltas de uma espiral, ou esboçasse três movimentos para observar as imagens formadas em um caleidoscópio, o tema da biblioteca pretende percorrer por três vias: virtual, imaginária e real, programadas de acordo com a sequência dos capítulos. No entanto, é preciso prevenir o leitor:

A obra crítica pode, decerto, muito honrosamente se sujeitar à aplicação de um programa preestabelecido. Mas é melhor que ela pareça uma viagem daqueles que "partem por partir”, sem saber onde a peregrinação os levará. ${ }^{10}$

Muitas vezes essas vias se entrecruzarão ao longo dos capítulos, pois ao mesmo tempo em que o tema da biblioteca se desdobra, ele apresenta pontos de convergência que não podem ser ignorados. Dessa forma, também me aproximo de uma crítica do imaginário, a outra frente da crítica temática apresentada por Tadié (1987), que privilegia a imaginação no lugar do sujeito, como propõe Gaston Bachelard, para quem a imagem “[...] não é nem uma figura retórica, nem um detalhe do texto, ela é um 'tema de totalidade. Ela chama à convergência as impressões mais diversas, as impressões que vêm de vários sentidos’.”11, e conclui que "o tema se combina com outros nos conjuntos, constituindo então um equilíbrio, por casais antitéticos ('o fechado e o aberto, o nítido e o fugidio’), sistemas múltiplos”"12. No entanto, apesar de me aproximar dessa crítica que trabalha com temas "que se combinam com outros nos conjuntos”, como proponho trabalhar com o tema da biblioteca nesta dissertação ao combiná-la com temas diversos, como o do caleidoscópio, da espiral, do veneno, da monstruosidade, do fantasma, entre outros, nas obras e nas práticas de leitura e escrita de Flaubert e Perec, não procurei compor um equilíbrio por temas duplos, como é comum entre os críticos temáticos, mas multiplicar aqueles temas a partir da leitura da biblioteca nas duas obras de Flaubert e Perec, que são tratadas paralelamente nos três capítulos.

No primeiro capítulo, “Assombros da biblioteca”, a biblioteca ressalta aos olhos como tema relacionado ao modo de ler livros. Isso porque, ao longo da pesquisa de Mestrado, a

\footnotetext{
${ }^{9}$ O desdobramento é uma condição das obras e, por isso, das bibliotecas. Segundo Butor (1974, p.193), “a obra se desdobra. Todo leitor não só constitui a partir dos sinais propostos uma representação, mas empreende a reescritura daquilo que lê."

${ }^{10}$ No original: "L'oeuvre critique, certes, peu très honorablement s'astreindre à l'application d'un programme préétabli. Mais il vaut qu'elle ressemble au voyage de ceux 'qui partent pour partir', sans savoir où la peregrination les mènera.” (STAROBINSKI, 2001b, p.35)

11 “[...] l'image, pour Bachelard, n'est ni une figure de rhétorique, ni un détail du texte, elle est 'un thème de totalité. Elle appelle à la convergence les impressions les plus diverses, les impressions qui viennent de plusieurs sens'." (TADIÉ, 1987, p. 110)

12 "Enfin, le thème se combine avec d'autres dans des ensembles, constituent alors un équilibre, par couples antithétiques ('le clos et l'ouvert, le net et le fuyant'), systèmes multiples”. (Ibid., p. 116)
} 
reescritura, que desde a Iniciação parecia-me um conceito mais próximo da análise que pretendia efetuar, começou a apresentar alguns entraves, sobretudo pelo fato de não me dedicar à análise de citações ou alusões pontuais de Flaubert programadas por Perec para entrar em seu livro, mas a uma leitura de imagens e temas que chamam minha atenção nos livros e a questões próprias da composição e forma dos romances, relatadas na biblioteca virtual dos escritores. Apesar de não me aprofundar nos manuscritos dos escritores, procurei abordar algumas questões suscitadas na correspondência de Flaubert e em entrevistas e no Cahier de Charges de La Vie mode d'emploi (1993), o qual apresenta manuscritos facsimilados de Perec. Essa reflexão é precedida, nesse capítulo, pela justificativa da escolha da biblioteca como metáfora da leitura de Flaubert e Perec e pelo debate desse conceito mais fluido e ficcional com os conceitos de intertextualidade e reescritura.

O segundo capítulo, “Os livros-bibliotecas de Flaubert e Perec”, é dedicado à biblioteca imaginária presente em BP e LVME, ou seja, à ficcionalização da biblioteca nesses romances por meio da caracterização dos personagens pesquisadores, da incorporação de saberes na ficção e da inclusão crítica de outros gêneros textuais mais descritivos, explicativos e didáticos que apontam para uma reflexão sobre o estatuto romanesco no final do século XIX até o século XX. Nesse capítulo, é enfatizado o papel da imaginação nessa leitura que não se quer diádica, mas relacional, mimetizando o próprio espaço da biblioteca.

No terceiro capítulo, “Da relação com os livros à coleção de quinquilharias”, destaco as bibliotecas reais de Gustave Flaubert e de Georges Perec como um espaço de relação e criação literária e reflito sobre como as formas de arquivamento refletem em procedimentos de escrita encontrados nos romances. Como exemplo, lembro o trabalho com listas e descrições e vice-versa. Isso porque entendo que as bibliotecas, privadas ou públicas, podem ser vistas como espelho de diversas identidades. Alberto Manguel (2006, p. 250), em seu A biblioteca à noite, define essa característica especular da biblioteca como caleidoscópica:

Pode ser que, dada sua qualidade caleidoscópica, toda biblioteca, por mais pessoal que seja, ofereça a quem a explore um reflexo do que ele ou ela procura, um torturante momento de intuição de quem somos como leitores, um vislumbre dos aspectos mais secretos do eu.

É esse aspecto caleidoscópico que me interessa, pois, mesmo que esta dissertação não seja sobre a biblioteca dos escritores, nem se proponha a uma análise de fragmentos deixados nas bibliotecas pessoais deles, é essa característica que me permite propor uma leitura de livros a partir das bibliotecas, concebendo-as como espaço de relação que reflete a imagem 
de seus próprios leitores. Nesse sentido, trago referências de outros livros que ficcionalizam a biblioteca seja como objeto principal, seja como pano de fundo a fim de apresentar os diferentes arranjos que as múltiplas peças desse caleidoscópio podem formar. Ao longo dos capítulos, percorro o tema da biblioteca em Flaubert e em Perec, com ênfase em seus respectivos romances de 1881 e de 1978, tratando paralelamente as práticas de leitura e escrita desses escritores e procurando refletir, em alguns momentos, sobre minhas próprias práticas de pesquisa e de escrita da dissertação. Esse exercício se deve à permanência daquela sedução pela citação mencionada anteriormente, isto é, trata da reflexão sobre um modo de usar o discurso dos outros para compor o meu próprio. Essa reflexão também é suscitada pela própria característica do tema da biblioteca dentro de livros que mimetizam espaço, personagens e fenômenos de bibliotecas ficcionalizadas por escritores ${ }^{13}$ que, por sua vez, tinham uma relação especial com livros e com o espaço de suas bibliotecas. Assim como esses escritores e personagens, encontro-me também no interior dessa imensa biblioteca, que pode oferecer, ao mesmo tempo, a liberdade da imaginação e o aprisionamento na ilusão:

\begin{abstract}
A biblioteca nos dá o mundo, mas ela nos dá um mundo falso; de quando em quando, produzem-se rachaduras, a realidade se revolta contra os livros, por intermédio de nossos olhos, por intermédio das palavras ou de certos livros, um exterior nos acena e nos dá uma sensação de enclausuramento; a biblioteca se transforma em torreão. (BUTOR, 1974, p. 193)
\end{abstract}

Os personagens Bouvard e Pécuchet não encontram uma saída do ciclo vicioso de sua busca pela completude, pela Verdade, pelo saber total, bem como LVME termina com uma abertura, uma brecha, já que o quebra-cabeças do personagem Bartlebooth não se completa. Também Flaubert e Perec são movidos por uma curiosidade extrema: o primeiro possui uma espécie de compulsão por leitura que o faz somar os livros que leu em suas anotações pessoais, o segundo procura experimentar com a linguagem em seus mais diferentes matizes (seja com o uso de restrições (contraintes) para a escrita, no Oulipo, seja com a mistura de gêneros em um livro e em sua obra como um todo) $)^{14}$.

\footnotetext{
13 Sobre essa tendência dos escritores, Butor (1974, p. 201) afirma: "Primeiro leitor, o escritor começa a propósito de seu próprio trabalho o que ele sabe fazer com o de outrem. Sua atividade vai refletir-se como num espelho. Em romances, ouviremos falar de pessoas que escrevem ou lêem romances.”

${ }^{14}$ Como frequentadora dessas bibliotecas, torno-me também um fantasma envenenado por esse tema ligado aos personagens e escritores, pois de acordo com Gaston Bachelard (1992, p. 9-10): “Todos sabem que lendo revivemos nossas tentações de ser poeta. Todo leitor, um pouco apaixonado pela leitura, alimenta e recalca, pela leitura, um desejo de ser escritor. [...] Nessa admiração que ultrapassa a passividade das atitudes contemplativas, parece que a alegria de ler é o reflexo da alegria de escrever, como se o leitor fosse o fantasma do escritor”. No original da introdução de La poétique de l'espace: "Personne ne sait qu'en lisant nous revivons nos tentations d’être poète. Tout lecteur, un peu passionné de lecture, nourrit et refoule, par la lecture, un désir d’être écrivain.
} 
O que fazer então com um mundo falso, com uma biblioteca que envenena e não apresenta saída? A sogra de Emma Bovary quis avisar a polícia sobre a função de envenenador do bibliotecário ${ }^{15}$, mas não é preciso ser tão radical, pois podemos lembrar que “o remédio poderia encontrar-se na vizinhança (ao lado) da planta venenosa, ou no próprio interior (na substância) do animal perigoso" ${ }^{16}$ (STAROBINSKI, 2001a, p. 164). Ora, aquela não passa de uma pergunta retórica para a qual já sabemos a resposta, por isso, aceitei correr os riscos ${ }^{17}$ da biblioteca e das obras:

É a inquietude e o sentimento da falta que são as fontes de inspiração crítica. Para responder à sua vocação plena, para ser discurso compreensivo sobre as obras, a crítica não pode permanecer nos limites do saber verificável; ela deve se fazer obra por sua vez, e correr os riscos da obra.

[...] En cette admiration qui dépasse la passivité des attitudes contemplatives, il semble que la joie de lire soit le reflet de la joie d'écrire comme si le lecteur était le fantôme de l'écrivain.”

${ }^{15}$ A Mme. Bovary (sogra) não se conforma com o fato de a nora ocupar seu dia apenas lendo romances "ruins”, “que debocham dos padres com discursos de Voltaire”. No original: “- Ah! Elle s'en occupe! À quoi donc? À lire des romans, de mauvais livres, des ouvrages qui sont contre la religion et dans lesquels on se moque des prêtres par des discours tirés de Voltaire. Mais tout cela va loin, mon pauvre enfant, et quelqu'un qui n’a pas de religion finit toujours par tourner mal.

Donc, il fut résolu que l'on empêcherait Emma de lire des romans. L'entreprise ne semblait point facile. La bonne dame s'en chargea: elle devait, quand elle passerait par Rouen, aller en personne chez le loueur de livres et lui représenter qu'Emma cessait ses abonnements. N'aurait-on pas le droit d'avertir la police, si le livraire persistait quand même dans son métier d'empoisonneur?” (FLAUBERT, 1998, p. 164, grifo meu)

${ }^{16}$ É dessa forma que Starobinski sintetiza o tema do veneno e do antídoto no Discurso sobre as ciências e as artes de Rousseau.

${ }^{17}$ No original, “car c’est l'inquiétude et le sentiment du manque qui sont les sources d'inspiration critique. Pour répondre à sa vocation plénière, pour être discours compréhensive sur les oeuvres, la critique ne peut pas demeurer dans les limites du savoir verifiable; elle doit se faire oeuvre à son tour, et courir les risques de l’oeuvre.” (STAROBINSKI, 2001b, p. 55, grifo meu) 


\section{Capítulo 1 - Assombros da biblioteca: modos de ler em relação e moldes de produção ficcional}

\section{Biblioteca como modo de ler em relação}

Os corredores da imensa biblioteca são povoados de fantasmas heteróclitos. Michel Butor

O que Butor condensa nesta frase final sobre a questão da imitação na prática de escrita crítica vai além da constatação de que retomamos antepassados para (re)descobrir nossos próprios assuntos e nossas próprias formas de escrever, ou seja, ultrapassa a ideia de que livros são feitos de outros livros. Esses diferentes fantasmas habitam não só os livros, cujas capas estampam o nome dos autores como lápides e cujos paratextos e referências finais revelam a rede genealógica do pensamento do escritor, mas povoam também os "frequentadores" da biblioteca, os leitores que carregam suas próprias sombras para esse espaço, as quais conversam inevitavelmente com os fantasmas que lá habitam. Além disso, na frase de Butor, também seria possível substituir o termo "biblioteca” pela palavra "livro", e ela se desdobraria em mais um sentido fantasmagórico: alguns livros ficcionalizam a dinâmica das bibliotecas, ou seja, foram escritos com base na reflexão sobre o imaginário desse espaço de relação entre tempos e saberes. Este é o caso dos romances La Vie mode d'emploi (1978), de Georges Perec, e Bouvard et Pécuchet (1881), livro póstumo de Gustave Flaubert, com os quais pretendo fazer meus fantasmas dialogarem neste capítulo, discutindo especificamente questões relacionadas às práticas de leitura e escrita desses escritores em alguns relatos que podem ser considerados amostras de suas "bibliotecas virtuais”.

Ligadas às bibliotecas reais de escritores, que representam um acervo concreto pertencente a um escritor, as bibliotecas virtuais são formadas por registros de leituras feitos em margens de livros, cadernos, correspondência, entrevistas, citações, enfim, marcas que revelam a quais “fantasmas” o escritor recorreu em determinado projeto de escrita ou em sua obra como um todo. Daniel Ferrer (2001) define a diferença entre esses dois espaços (real e virtual) de interação entre livros e a escrita a partir do papel do pesquisador que elege um ou outro como objeto de estudo. A biblioteca real, segundo ele, coloca o pesquisador diante de uma “coleção de volumes” de um escritor, que geralmente apresenta marcas de suas práticas de leitura e escrita; já a biblioteca virtual seria aquela construída pelo pesquisador, o qual reúne as diversas referências intertextuais mencionadas anteriormente como levantamento dos documentos da gênese da escrita. No entanto, Ferrer também aponta fronteiras fluidas 
existentes entre as bibliotecas reais e virtuais, pois muitas vezes o pesquisador precisa “virtualizar as bibliotecas tangíveis” e encontra, "graças às bibliotecas virtuais, o detalhe de

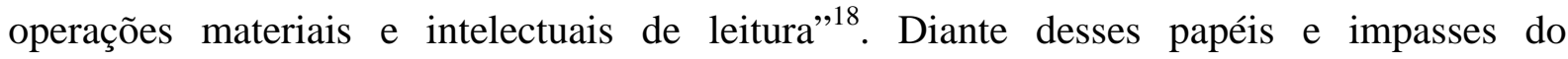
pesquisador que estuda a biblioteca dos escritores, é importante destacar que não me debrucei sobre os livros das bibliotecas reais de Flaubert e Perec. Também não proponho uma reconstrução do percurso de criação dos romances anteriormente citados a partir de traços deixados em suas bibliotecas virtuais, tampouco pretendo fazer uma leitura das referências/citações programadas pelos autores das obras. Mais me interessa refletir de que forma as práticas de leitura e escrita desses escritores podem tensionar o modo como lemos suas obras.

Por isso, recorro a relatos das práticas de escrita de Perec, presentes em algumas entrevistas e em seu Cahier des charges de La Vie mode d'emploi (1993), e de Flaubert, em relatos de sua correspondência e no excerto de um manuscrito. Tomados como vestígios de suas bibliotecas virtuais, tais relatos permitem pensar sobre como eles liam e como nós, pesquisadores e/ou críticos, costumamos relacionar livros. Isso porque estes últimos estão habituados a definir conceitos, por vezes, bastante técnicos para analisar obras literárias, uma prática que não se assemelha à daqueles escritores que, muitas vezes, compõem críticas a outros livros em suas próprias obras literárias.

Este capítulo sugere um tipo de leitura que coloca os livros lado a lado na estante da página e privilegia o sujeito-leitor que percebe que ler Perec pode modificar e abrir um novo leque de formas de ler Flaubert e vice-versa.

É importante destacar que apesar de dialogar com dois romances e me referir a questões instigadas por relatos de suas bibliotecas virtuais, não pretendo eleger um livro como texto-base (“fonte”) ou defender uma hierarquia entre escritores, gêneros literários, épocas, etc. É por isso que Perec será tratado antes de Flaubert neste capítulo: primeiro porque o conheci antes em meu próprio percurso como leitora, segundo, porque foi a partir de Perec que comecei a formular questões para ele e para Flaubert.

Recorrerei a esses relatos de procedimentos de escrita que compõem as chamadas bibliotecas virtuais dos escritores tendo em mente a metáfora da biblioteca como um fenômeno de leitura, sobretudo de uma leitura que coloca os livros numa rede relacional. Isso

\footnotetext{
18 "Mais cette fiddérence se trouve relativisée par la nécessité paradoxale de virtualiser les bibliothèques tangibles et de retrouver, grâce aux bibliothèques virtuelles, le détail des opérations matérielles et intellectuelles de lecture.” (FERRER, 2001, p. 15) Cf. a introdução de Daniel Ferrer ao livro Bibliothèques d'écrivains, intitulada “Un imperceptible trait de gomme de tragacanthe...” In: FERRER; D’IORIO, 2001, p. 7-27
} 
porque os textos que mais estimularam minha própria escrita sobre Flaubert e Perec são de escritores que fazem justamente isso, como Ítalo Calvino ${ }^{19}$, Jorge Luis Borges ${ }^{20}$, Umberto $\mathrm{Eco}^{21}$, Michel Foucault ${ }^{22}$, entre tantos outros ${ }^{23}$ que prolongaram a sedução de suas leituras ou de suas bibliotecas em seus textos, seja com propósito ensaístico, crítico e/ou ficcional.

A metáfora da biblioteca é geralmente entendida como uma forma menos técnica de tratar da conversa entre tomos, por ser muito abrangente ou por trazer apenas a ideia de repetição, no caso, na literatura ${ }^{24}$. No entanto, ao mesmo tempo em que ela se expande, esta metáfora da biblioteca aponta para uma leitura muito particular, como propõe João Alexandre Barbosa (1996), na orelha de sua Biblioteca Imaginária:

A metáfora utilizada como título deste livro é, ao mesmo tempo, muito abrangente e muito particular. Por um lado, indica o modo pelo qual cada um, com a experiência da leitura e dos textos, vai estabelecendo uma seleção de autores e livros dentro de uma ampla biblioteca já sancionada pelo tempo; por outro lado, todavia, procura resgatar a individualidade da escolha que é assinalada pelo imaginário do leitor.

É por essa razão que escolho a biblioteca como modo e tema de leitura. Diferentemente de outros conceitos mais técnicos que discutirei adiante, a ambiguidade e a fluidez conferem à metáfora da biblioteca uma grande riqueza ${ }^{25}$, pois ela pode apresentar muitas questões para seus leitores, mas escapa entre as palavras do texto caso ele tente utilizála como simples instrumento de análise. Por isso, também devo esclarecer que falar da

\footnotetext{
${ }^{19}$ Refiro-me especificamente às lições americanas reunidas no livro Seis propostas para o próximo milênio. (CALVINO, 1990)

${ }^{20}$ São lembrados aqui alguns contos de Ficções (BORGES, 2001), como "Pierre Menard, o autor do Quixote", "O Jardim de veredas que se bifurcam" e "A Biblioteca de Babel".

${ }^{21}$ Aqui, lembro da conferência "Borges e a minha angústia da influência”, publicada no livro Sobre a literatura. (ECO, 2003, p. 113-127)

${ }^{22}$ Trato especificamente de seu texto "A biblioteca fantástica” ou "Posfácio a Flaubert (A tentação de Santo Antão)”. (FOUCAULT, 2006, p.75-101).

${ }^{23}$ Poderia citar, por exemplo, o belo ensaio com teor biográfico A Biblioteca à noite (2006), de Alberto Manguel, A orgia perpétua (1979), de Mario Vargas Llosa, o projeto “O Bairro" e o livro Biblioteca (2009), de Gonçalo Tavares, os quais, embora não sejam tratados aqui, pertencem a meus bastidores da escrita.

${ }^{24}$ É o ponto de vista de Samoyault, por exemplo, nos seguintes trechos de A intertextualidade: "O termo intertextualidade foi tão utilizado, definido, carregado de sentidos diferentes que se tornou uma noção ambígua do discurso literário; com frequência, atualmente, dá-se preferência a esses termos metafóricos, que assinalam de uma maneira menos técnica a presença de um texto em outro texto: tessitura, biblioteca, entrelaçamento, incorporação ou simplesmente diálogo.” (SAMOYAULT, 2008, p. 9). “Com a biblioteca, a literatura mantém uma relação de repetição; em compensação, a biblioteca exerce sobre o texto um poder de modelização. Ela
} constitui então um filtro entre o texto e o mundo.” (SAMOYAULT, 2008, p.123)

${ }^{25}$ Para o narrador de "Pierre Menard, autor do Quixote”, “a ambiguidade é uma riqueza”. (BORGES, 2001, p. 61) 
biblioteca apenas como sedução e espaço da imaginação seria dizer que o veneno da biblioteca é apenas remédio para cura, para transcendência e expiação de meus próprios fantasmas. Assim, poderia começar este capítulo mais tranquila, e talvez sem grandes problemas, mas a biblioteca também possui outro tipo de veneno, pois além de ser o lugar que reúne saberes, um espaço de memória, também é um lugar de esquecimento e exclusão, por ser, muitas vezes, regido por escolhas (políticas, históricas, pessoais), ligadas à eleição de um cânone em detrimento de outros livros.

Esta é uma questão inerente às bibliotecas desde seus primórdios, tanto pela definição de quem tinha/tem o poder de conservar e consultar o acervo quanto pelo modo como é sistematizada. Nascidas em "berços de ouro", para trazer um breve relato, as primeiras bibliotecas estavam ligadas àqueles que detinham poder social (reis, faraós e sacerdotes) e demoraram séculos para se tornar acessíveis a todos. Essa característica também é imposta na montagem dos acervos, nos critérios que determinam se um documento (para incluir também os papiros, tabuletas e pergaminhos além do irmão mais novo, o livro) merece ou não ser protegido. Tudo isso tem muitos desdobramentos na forma como nos relacionamos com o conhecimento, já que, ao longo da história, muitos acervos se perderam. Podemos nos lembrar da mais famosa biblioteca fantasma da história, a Antiga Biblioteca Alexandria, fundada em III a. C., cuja destruição ainda permanece um mistério. Incendiada ou não, essa biblioteca representa uma das maiores perdas do mundo antigo. Além dos fatos históricos que nos deixaram órfãos de inúmeros acervos, poderíamos discutir também as formas de acesso que temos a diversos arquivos que “sobreviveram” às intempéries do tempo, das guerras, das fornalhas, do domínio de tiranos e que hoje permanecem longe dos nossos olhos e guardados a sete chaves seja por questões geográficas (bibliotecas internacionais), institucionais (acesso restrito) ou financeiras (colecionadores que detém arquivos, livros, manuscritos como objetos de valor). Algumas dessas questões podem até ser resolvidas com uma viagem ou consulta na Internet, mas ainda não tornam a Biblioteca um espaço aberto para todos. Mesmo assim, a biblioteca não deixa de ser um espaço de memória e de relação, entretanto, é preciso ter em mente que se trata de uma memória construída pela História (aliás, como é natural à memória), a qual permite que alguns livros permaneçam e ocupem as prateleiras das bibliotecas.

Essas escolhas presentes nas bibliotecas reais também se relacionam com as bibliotecas virtuais dos escritores e com meu próprio objeto de pesquisa. Isso porque, é evidente, os escritores que trago para essa leitura em relação são clássicos, cânones da literatura francesa, que escolho como objeto de estudo em detrimento de muitos outros, o que 
traz uma série de riscos. Assim como João Alexandre Barbosa (1996) que começa seu artigo “Os Intervalos de Eça de Queiroz” mostrando que sua leitura pode parecer repetitiva, dada a importância da fortuna crítica desse escritor português, também entendo que esta leitura de Perec e Flaubert é, na verdade, uma releitura. Uma releitura de escritores que também foram releitores de clássicos, como comprovam suas bibliotecas (virtuais e reais - o próprio epílogo de LVME cita diversos escritores canônicos). De acordo com Calvino (2007, p. 11):

Os clássicos são aqueles livros que chegam até nós trazendo consigo as marcas das leituras que precederam a nossa e atrás de si os traços que deixaram na cultura ou nas culturas que atravessaram (ou mais simplesmente na linguagem ou nos costumes). (CALVINO, 2007, p. 11)

Logo, entender a biblioteca como modo de leitura não prevê apenas um exercício livre de imaginação, mas a consciência de que procuro me inserir num sistema literário, por meio da atualização de aspectos das obras escolhidas para o momento presente. Assim, a proposta deste capítulo é justificar a adoção dessa metáfora da biblioteca como modo de ler em relação a partir da abordagem de algumas noções, já estabelecidas no discurso crítico, utilizadas para relacionar dois ou mais textos e da apresentação de elementos do projeto estético do Oulipo e de características das práticas de escrita de Perec e de Flaubert. Dessa forma, procuro discutir alguns conceitos críticos relacionados a um fenômeno de leitura que reconhece a presença de livros dentro de um livro para, em seguida, refletir sobre como esse fenômeno aparece nos “moldes” da produção ficcional de Perec e Flaubert, especificamente em LVME e BP.

\section{Conversa entre tomos}

O narrador da "Biblioteca de Babel” lembra que “ninguém pode articular uma sílaba que não esteja cheia de ternuras e de temores” (BORGES, 2001, p. 99), mas continuamos a articulá-las, as mesmas palavras, compostas pela combinação de 26 letras. Copiamos incessantemente, seguindo o método tradicional “recorta e cola” e, atualmente, CTRL + C, CTRL + V, e repetimos mesmo quando achamos que tudo já foi dito.

Muitos nomes e acepções surgiram ao longo da história da teoria literária no sentido de explicar, por vezes de forma bastante técnica, de que modo um livro é feito de outros livros, como intertextualidade, reescritura, hipertextualidade... Não poderia me furtar à discussão desses conceitos tão importantes para a compreensão da poética desses escritores, cujas obras operam com outros discursos, incorporando-os, mimetizando-os ou criticando-os 
em sua própria escrita, de tal forma que esse trabalho ganha, às vezes, mais destaque do que o próprio enredo dos livros.

O conceito mais estabelecido para relacionar livros é a intertextualidade, que foi introduzida por Julia Kristeva a partir da teoria bakhtiniana de dialogismo e polifonia. A ideia inicial desse conceito sugeria o diálogo entre textos de forma ampla, ou seja, como instrumento estilístico e também como noção poética, no caso de uma alusão de um texto a outro ou no do uso de uma citação direta. Ao longo da história da teoria literária, esse conceito foi se tornando cada vez mais instável devido à ambiguidade presente já em seu sentido inaugural, como mostra o estudo histórico e crítico feito pela professora Tiphaine Samoyault em $A$ intertextualidade. Ela analisa as diversas nuances que essa noção foi adquirindo no discurso literário e defende a intertextualidade como memória da literatura ${ }^{26}$.

A pesquisa de Samoyault mostra que apesar de instáveis, as definições de intertextualidade que coexistiram de 1969, quando Kristeva cunhou o termo, até 1981 parecem se complementar no sentido de compreender de forma ampla as características do movimento dos textos.

A partir da década de 1960, com o período estruturalista, os críticos procuram se libertar da noção de influência e da busca de fontes, que serviam à crítica biográfica, para dar lugar a noções em torno das imagens da rede e da correspondência entre os textos. Essa mudança foi importante para implicar o leitor nessa grande rede de relações entre os textos. É sob essa perspectiva que Barthes, em 1973, fala sobre sua leitura de Flaubert a partir de Proust, tomando este último como peça-chave de tudo que lê, como uma referência importante sem posicioná-lo num lugar hierarquicamente superior, mas tomando-o como uma “lembrança circular”. É essa circularidade que Barthes vai propor para definir o intertexto: "É bem isso o intertexto. A impossibilidade de viver fora do texto infinito.” (BARTHES, 1993, p.49) ${ }^{27}$

Essa responsabilidade do leitor na compreensão da intertextualidade será reforçada por Michel Riffaterre em 1981. Para ele, a intertextualidade é mais próxima da noção proposta por Barthes em O prazer do texto, isto é, como um "fenômeno que orienta a leitura do texto,

\footnotetext{
26 “O que ela é, com efeito, senão a memória que a literatura tem de si mesma?” (SAMOYAULT, 2008, p. 10)

27 “Alhures, mas da mesma maneira, em Flaubert, são as macieiras normandas em flor que leio a partir de Proust. Saboreio o reino das fórmulas, a inversão das origens, a desenvoltura que faz com que o texto anterior provenha do texto ulterior. Compreendo que a obra de Proust é, ao menos para mim, a obra de referência, a mathesis geral, a mandala de toda a cosmogonia literária - como o eram as Cartas de Mme de Sévigné para a avó do narrador, os romances de cavalaria para D. Quixote, etc.; isto não quer de modo algum dizer que sou um 'especialista' de Proust: Proust, é o que me ocorre, não é o que eu chamo; não é uma 'autoridade'; é simplesmente uma lembrança circular."
} 
que governa eventualmente a interpretação desta, e que é o contrário da leitura linear” (RIFATERRE, 1981, p.5-6) (28 $^{2}$ Já o intertexto seria um “corpus indefinido”, pois depende da cultura de um leitor mais iniciado, que reconheceria marcas de outros textos. Rifatterre critica justamente as análises que confundem o estudo da intertextualidade com a caça aos intertextos, o que reduziria a abrangência desse fenômeno como memória da literatura. Isso porque tanto Rifatterre quanto Barthes, mesmo utilizando termos um pouco diferentes, defendem esse fenômeno a partir do reconhecimento de que os textos não são estéreis, ou seja, de que as palavras que os compõem "significam por referência a complexos de representação já completamente integrados ao universo da linguagem.” (RIFATERRE, 1981, p.6) ${ }^{29}$. Além disso, ambos caracterizam essa noção a partir de um deslocamento da noção retórica de representação e emulação.

É nesse sentido que Barthes analisa a descrição flaubertiana, no ensaio "Effet de réel”, de 1968. Neste ensaio, Barthes destaca um trecho descritivo da sala de Mme Aubain, do conto “Un Coeur Simple”, e mostra como um detalhe, no caso um barômetro, não é simplesmente citado por Flaubert, mas "situado na cena, em um sintagma ao mesmo tempo referencial e sintático”30 (BARTHES, 2002, p. 26). Por meio do trabalho com a precisão da linguagem em suas descrições, Flaubert dialoga com a retórica clássica ${ }^{31}$, cuja figura da hipotipose prezava

28 “Je redéfinirai donc ainsi l'intertextualité: il s'agit d'un phénomène qui oriente la lecture du texte, qui en
gouverne éventuellement l'interprétation, et qui est le contraire de la lecture linéraire.”
${ }^{29}$ Para estender um pouco mais a citação de Riffaterre, a intertextualidade “é o modo de percepção graças ao
qual o leitor toma consciência do fato de que, na obra literária, as palavras não significam por referência às
coisas ou a conceitos, ou mais geralmente por referência a um universo não-verbal. Elas significam por
referência a complexos de representação já completamente integrados ao universo da linguagem. Esses
complexos podem ser textos conhecidos, os quais reconhecemos, em um novo contexto, e que lhes preexistiam
[...].” No original: “C’est le mode de perception grâce auquel le lecteur prend conscience du fait que, dans
l’oeuvre littéraire, les mots ne signifient pas par référence à des choses ou à des concepts, ou plus généralement
par référence à un univers non-verbal. Ils signifient par référence à des complexes de représentations déjà
entièrement intégrés à l'univers langagier. Ces complexes peuvent être des textes connus, ou des fragments de
textes qui survivent à la séparation de leur contexte, et dont on reconnaît, dans un nouveau contexte, qu’ils lui
préexistaient.”. Para Barthes, “o texto tem necessidade de sua sombra: essa sombra é um pouco de ideologia, um
pouco de representação, um pouco de sujeito: fantasmas, bolsos, rastros, nuvens necessárias; a subversão deve produzir seu próprio claro-escuro”. (BARTHES, 1993, p. 44)

30 “(en réalité, le mot pur n’existe pas: le baromètre de Flaubert n’est pas cité en soi; il est situé, pris dans un syntagme à la fois referentiel et syntaxique)”.

31 “Todavia, o fim estético da descrição flaubertiana é toda misturada a imperativos 'realistas, [...] as restrições estéticas se impregnam aqui - ao menos a título de álibi - de restrições referenciais. [...] a retórica clássica tinha em alguma medida institucionalizado o fantasma sob o nome de uma figura particular, a hipotipose, encarregada de 'colocar as coisas sob os olhos do ouvinte' nunca de uma forma neutra, constativa, mas deixando à representação toda chama do desejo (isso fazia parte do discurso vivamente claro, com contornos expressivos: o illustris oratio); renunciando declaradamente às restrições do código retórico, o realismo deve procurar um novo motivo para descrever." No original: "Toutefois, la fin esthétique de la description flaubertienne est toute mêlée d'impératifs 'réalistes', [...] les contraintes esthétiques se pénètrent ici - du moins à titre d'alibi - de contraintes référentielles. [...] la rhétorique classique avait en quelque sorte institutionnalisé le fantasme sous le nom d'une figure particulière, l'hypotypose, chargée de 'mettre les choses sous les yeux de l'auditeur' non point d'une 
pela produção de uma sensação de realidade nas descrições. No entanto, ao mesmo tempo, ele renuncia a esse efeito, já que produz outro, uma ilusão referencial, a partir de um signo (barômetro) que não possui referencial na cena. Mas o que a descrição tem a ver com a intertextualidade? Philippe Hamon (1993, p. 48) vai definir a descrição como operador de intertextualidade:

[...] um saber (de palavras, de coisas) é não apenas um texto já aprendido, mas também um texto já escrito em outro lugar, e a descrição pode então ser considerada sempre, mais ou menos, como o lugar de uma reescritura, como um operador de intertextualidade; de-scribere, lembremo-nos, etimologicamente, é escrever a partir de um modelo. ${ }^{32}$

Indo além dessa forma de compreender a descrição como operador de intertextualidade, penso que a descrição também pode abrir espaço para a relação entre os textos, o que desenvolverei com mais cuidado na análise dos trechos descritivos do Capítulo 3 desta dissertação. Por ora, adianto que foi a observação desse procedimento de escrita que me permitiu relacionar pela primeira vez os romances de Flaubert e Perec ${ }^{33}$. Isso porque Flaubert apresenta um trabalho característico da descrição, que Barthes (1993, p. 37) definiu como "um excesso de precisão, uma espécie de exatidão maníaca da linguagem, uma loucura de descrição (que se encontra nos textos de Robbe-Grillet)” e que Perec retomou logo em seu primeiro romance Les choses, de 1965. Além disso, Perec trabalha diversas potencialidades da descrição ao longo de sua obra, seja como contrainte (restrição) da ficção (é o caso dos capítulos de $L V M E$ que se iniciam sempre com um trecho descritivo), seja como procedimento de escrita de sua produção crítica (por exemplo, nos ensaios de Penser/Classer), como apresentarei no Capítulo 3 deste trabalho.

Voltemos à síntese da mobilidade dos conceitos de relação entre os textos, que não foram tão problematizados até agora. Em 1981, Genette marca o início da confusão em torno da intertextualidade, segundo Samoyault. Isso porque Gérard Genette (1982, p. 7-18) restringe o sentido desse conceito colocando-o entre os cinco tipos de relação “transtextuais”. Nesta

façon neutre, constative, mais en laissant à la représentation tout l'éclat du désir (cela faisait partie du discours vivement éclairé, aux cernes colorés: l'illustris oratio); en renonçant déclarativement aux contraintes du code rhétorique, le réalisme doit chercher une nouvelle raison de décrire.” (BARTHES, 2002, p. 29-30)

32 "[...] un savoir (de mots, de choses) est non seulement un texte déjà apris, mais aussi un texte déjà écrit ailleurs, et la description peut donc être considérée toujours, peu ou prou, comme le lieu d'une réécriture, comme un opérateur d'intertextualité; de-scribere, rappelons-le, étymologiquement, c'est écrire d'après un modèle.”

${ }^{33}$ Minha primeira aproximação do trabalho descritivo de Flaubert e de Perec pode ser conferida no artigo "O Pesadelo de um Milhão de Coisas - A escrita da alucinação em Flaubert e Perec" publicado na Revista Criação e Crítica (online), n. 3. 2009, p.129-143. 
classificação, temos a intertextualidade que, retomando Kristeva, refere-se à percepção do leitor da relação entre um texto literário anterior e outro posterior, no qual a alusão está inserida. A seu lado, encontram-se as relações de paratextualidade, sendo o paratexto o “redor” do texto (título, notas, ilustrações, epígrafes, etc.); a de metatextualidade, que corresponde à relação crítica, por excelência, por englobar o “comentário”, a comparação alusiva que une os textos; a de arquitextualidade, referente ao gênero a que pertence determinado texto (poesia, ensaio, romance...); e a de hipertextualidade, cuja definição será desenvolvida ao longo de todo o livro, que trata de uma relação através da qual dois textos, no mínimo, operam certas transformações sem necessariamente haver citação:

Há em todo hipertexto uma ambiguidade que Riffaterre recusa na leitura intertextual, que ele define mais como um efeito de 'silepse'. Essa ambiguidade está precisamente no fato de que um hipertexto pode ao mesmo tempo ser lido por si mesmo, e em sua relação ao seu hipotexto. [...] O hipertexto nos convida a uma leitura relacional cujo sabor, perverso o quanto quiser, condensa-se bem naquele adjetivo inédito que inventou antes Philippe Lejeune: leitura palimpsestuosa. Ou, para deslizar de uma perversidade a outra: se amamos verdadeiramente os textos, devemos desejar, de tempos em tempos, amar (ao menos) dois de uma vez só. ${ }^{34}$

Genette restringe, por um lado, a noção de intertextualidade definindo-a como uma relação identificável e explícita entre dois ou mais textos, seja pela citação, pelo plágio, pela alusão ou por qualquer outro detalhe, como o estudo da silepse proposta por Riffaterre, ou pelos tipos de influência propostos por Bloom. Por outro, Genette propõe uma nova tipologia para abarcar a amplitude do sentido que a intertextualidade também carregava até então: a de ser um fenômeno próprio da literariedade, ou seja, como característica própria dos textos, que são sempre formados por outros (literários ou não) e que o leitor pode ou não identificar dependendo de sua cultura. Assim, ele reúne todos os tipos de relação entre os textos como transtextualidade e dedica seu Palimpsestes a definir e analisar este conceito que diz respeito a "toda relação unindo um texto B (que chamarei de hipertexto) a um texto anterior A (que

\footnotetext{
34 "Il y a dans tout hypertexte une ambiguïté que Riffaterre refuse à la lecture intertextuelle, qu'il définit plus volontiers par un effet de 'sylepse'. Cette ambiguïté tient précisément au fait qu'un hypertexte peut à la fois se lire pour lui-même, et dans sa relation à son hypotexte. [...] L'hypertexte nous invite à une lecture relationnelle dont la saveur, perverse autant qu'il voudra, se condense assez bien dans cet adjective inédit qu'inventa naguère Philippe Lejeune: lecture palimpsestueuse. Ou, pour glisser d'une perversité à une autre: si l'on aime vraiment les textes, on doit bien souhaiter, de temps en temps, en aimer (au moins) deux à la fois.” (GENETTE, 1982, p. 555-557)
} 
chamarei, certamente, hipotexto) sobre o qual ele se insere de uma maneira que não é aquela do comentário”. (GENETTE, 1982, p. 13) ${ }^{35}$

Por meio de sua defesa à "literatura em segundo grau”, Genette mostra como a humanidade sempre procurou investir novos sentidos a formas antigas, descartando, contudo, a possibilidade de uma perda de liberdade criativa ou de uma submissão aos antecessores, como propôs Harold Bloom ${ }^{36}$ em 1973. Nesse sentido, ele conclui seu Palimpsestes apontando a importância do caráter lúdico da hipertextualidade (“[...] o prazer do hipertexto é também um jogo»37), que ele afirma ter ligação com a arte da bricolagem, cuja definição ele empresta de Lévi-Strauss ${ }^{38}$. Essa arte passa a ser entendida por Genette como uma forma de compreender o trabalho lúdico presente no modo de construção do novo a partir de fragmentos do passado. Assim, a noção de hipertextualidade de Genette desloca o foco mais para o lado da produção desses textos que se relacionam com outros textos, ou seja, para a forma como o escritor vai trabalhar com esses outros em seus escritos, de forma programada ou não.

É nesse contexto que surge a noção de reescritura, que é definida em contraste com a noção de intertextualidade. Enquanto a intertextualidade seria uma qualidade do texto, ou seja, algo inerente a ele, já que reconhecemos que todo texto dialoga com outros, a reescritura estaria ligada à prática do escritor frente à própria escritura, quando opera uma transformação do texto base. Nesse sentido, a noção de reescritura é semelhante à de hipertextualidade de

\footnotetext{
35 “C'est donc lui que je rebaptise désormais hypertextualité. J'entends par là toute relation unissant un texte B (que j’appellerai hypertexte) à un texte antérieur A (que j’appellerai, bien sûr, hypotexte) sur lequel il se greffe d'une manière qui n'est pas celle du commentaire."

${ }^{36}$ A teoria de Bloom em A angústia da influência remete à afirmação de La Bruyère, em 1688, de que "tudo está dito, e chegamos demasiado tarde, há mais de sete mil anos que há homens, e que pensam.” (LA BRUYÈRE apud SAMOYAULT, 2008, p. 68), como se confere nesta afirmação sobre William Blake: "Estar escravizado ao sistema de qualquer precursor, diz Blake, é se ver inibido em sua criatividade por um mecanismo obsessivo de racionalização e comparação. A Influência Poética é, portanto, uma doença da autoconsciência e Blake mesmo não estava livre de sua parcela de angústia.” (BLOOM, 1991. p. 61). Sua proposta se baseia na teoria psicanalítica freudiana e na ideia de desapropriação (misprision) entre poemas: "De um ponto de vista conceitual, o problema maior para o poeta tardio é inevitavelmente a repetição, porque a repetição elevada dialeticamente à re-criação é a 'rota do excesso' do efebo, que o conduz para longe do horror de se descobrir a si mesmo como uma réplica, ou mera cópia do precursor.” (BLOOM, 1991, p. 116)

37 “[...] le plaisir de l'hypertexte est aussi un jeu.” (GENETTE, 1982, p. 557)

${ }^{38}$ É importante ressaltar que Lévi-Strauss está utilizando o termo bricolagem, em seu O pensamento selvagem, de 1962, como imagem para refletir sobre o pensamento mítico (criação/funcionamento de mitos e ritos): "Mythical thought is therefore a kind of intellectual 'bricolage' - which explains the relation which can be perceived between the two.” (LÉVI-STRAUSS, 1966. p. 17)
} 
Genette, como define Anne-Claire Gignoux (2003) ${ }^{39}$, em seu La récriture: formes, enjeux, valeurs.

A proposta de Gignoux é um pouco mais radical que a de Genette, pois afirma que a intertextualidade é um fenômeno ligado exclusivamente à recepção, enquanto a reescritura concerne apenas à produção. Para ela, o "problema"40 da intertextualidade, aliada à recepção, está no fato de que o intertexto pode variar segundo o leitor de diferentes países, culturas e repertório de leitura. Assim, como a intertextualidade estaria ligada a um domínio muito subjetivo da linguagem, ela propõe o estudo da reescritura ${ }^{41}$, que é dividida em duas formas: a réécriture como o ato do escritor durante a preparação do texto, incluindo rasuras e acréscimos ao longo da redação do texto; e a récriture como o ato programado de transformação de outro texto já publicado (do próprio escritor ou de outro).

Mesmo questionável, o enfoque que as noções de hipertextualidade e reescritura deram à produção dos textos permitem uma valorização do aspecto crítico da escritura “programada” para incluir outros textos. Um exemplo desse exercício de escrita críticoficcional são os Pastiches et Mélanges, de Proust, em que o escritor seleciona estilos de outros escritores e os exercita em seu próprio texto. O pastiche, neste caso, não é uma mera ferramenta para realização desse exercício de escrita, pois o autor a torna perceptível logo no título de cada texto, por exemplo: “O caso de Lemoine visto pelos Goncourt”, “O caso de Lemoine visto por Saint-Simon”. Proust define sua crítica baseada na imitação como "crítica em ação” e Genette (1982, p. 160) complementa afirmando que o pastiche em Proust “não é uma prática acessória, pura catarse estilística ou simples exercício pré-romanesco: trata-se, através da reminiscência e da metáfora, de uma das vias privilegiadas [...] de sua relação com o mundo e com a arte." ${ }^{42}$

\footnotetext{
${ }^{39}$ Refiro-me mais especificamente ao artigo "Da intertextualidade à reescritura", que a autora publicou tanto no livro La récriture: formes, enjeux, valeurs, em 2003, como nos Cahiers de Narratologie, n.13, em 2006.

40 “Partant, se soulève le problème majeur de l’intertextualité: parce que le récepteur établit l'intertexte, cet intertexte peut varier d'un lecteur à l'autre, selon la culture et les lectures antérieurs des lecteurs. [...] On ne peut nier que l’intertextualité soit un phénomène de réception.” (GIGNOUX, 2006. Não Paginado.)

${ }^{41}$ Utilizo apenas o termo reescritura (com dois es) por não estar preocupada com as diferenças entre a reescritura genética ou intertextual, já que ambas trazem a ideia de transformação programada pelo escritor, que é a mais importante aqui. Cf. um estudo mais detido sobre esse conceito de reescritura em meu artigo "Um modo de ler um livro-biblioteca: a reescritura perecquiana na composição de La Vie mode d'emploi”, publicado pela Revista de Letras da Unesp, São Paulo, v. 50, p. 129-145, jan/jul. 2010. Disponível em: <http://seer.fclar.unesp.br/letras/article/view/3169> Acesso em 21. fev. 2012.

42 “Le pastiche n’est donc pas chez Proust une pratique accessoire, pure catharsis stylistique ou simple exercice pré-romanesque : il est, avec la réminiscence et la métaphore, l'une des voies privilégiées - et à vrai dire obligées - de son rapport au monde et à l’art. ”
} 
Entre essas noções que reforçam a ideia de uma memória da literatura ora a partir da leitura, ora a partir de procedimentos formais, é possível observar um traço comum: a cronologia dessa memória. Isto porque essas noções perpetuam a ideia de um texto anterior que é retomado por um escritor seguinte, ou seja, apresentam uma relação linear entre os textos, do mais antigo ao mais novo. Será que essas noções dariam conta de explicar o acaso produzido, por exemplo, pelas re-criações propostas pelos membros do grupo Oulipo?

\section{No sentido oposto: Oulipo e o plágio antecipado}

O Ateliê de Literatura Potencial (Ouvroir de Littérature Potentielle - OuLiPo), fundado por François Le Lionnais em novembro de 1960 e divulgado por Raymond Queneau, propõe a criação de textos literários a partir de procedimentos e contraintes (restrições). Segundo Le Lionnais, no primeiro manifesto "La Lipo”, há duas tendências distintas que permeiam os trabalhos do grupo: Análise, que trabalha sobre as obras do passado; e Síntese, vocação do OuLiPo, que pretende descobrir novas vozes, até então desconhecidas, das obras de seus precursores.

Os trabalhos do OuLiPo são exaustivos, no que diz respeito à busca de novos efeitos a partir do trabalho com a forma, através da criação de inúmeras contraintes: os lipogramas, poesias-matemáticas, romances que parecem criar uma armadilha para o leitor, etc. A essa experimentação formal, Genette (1982, p. 67) dá o nome de oulipismo, que desloca o sentido original da paródia:

A paródia é um jogo de endereçamento; o oulipismo é um jogo de azar, como a roleta. Mas (como o subtítulo do Oulipo confessa) essa recreação arriscada não pode demorar muito tempo para se tornar recriação, pois a transformação de um texto produz sempre um outro texto, e portanto um outro sentido. ${ }^{43}$

Nessa recriação lúdica a partir de contraintes formais, os oulipianos esbarram em estruturas que já haviam sido criadas anteriormente. No segundo manifesto oulipiano, Le Lionnais propõe um olhar diferente para a questão entre poetas antigos e modernos, recusando a eleição de um modelo original e de uma cópia por meio da definição do trabalho do Oulipo como “plágio por antecipação”. Dessa forma, “justiça é feita e cada um recebe de acordo com

\footnotetext{
43 “La parodie est un jeu d'adresse; l'oulipisme est un jeu de hasard, comme la roulette. Mais (comme l'avoue le sous-titre d'Oulipo) cette récréation hasardeuse ne peut manqué longtemps de devenir recréation, car la transformation d'un texte produit toujours un autre texte, et donc un autre sens.”
} 
seus méritos” ${ }^{\star 4}$. Essa noção coloca em xeque a primazia da memória cronológica, apontando para uma direção diferente no que diz respeito à relação entre os textos, seja pelas práticas de escrita ou pelas práticas de leitura.

Os procedimentos de escrita experimentais que visam à pesquisa das potencialidades da literatura não são considerados pelos oulipianos como simples cópias ou imitações (ou qualquer outra palavra que remeta à ideia de precursor). Para eles, a literatura potencial é a literatura a ser feita a partir do jogo com a escrita, algo que sempre existiu na história literária, como destaca Perec em seu estudo sobre a história do lipograma, mas que ficou registrado à margem da alta literatura, ocupando o capítulo de curiosidades e frivolidades literárias. Colocando o jogo de escrita em foco, segundo Perec, "a lista que o Oulipo começa a estabelecer de seus ‘plagiários por antecipação' tem todas as chances de acabar por constituir um novo Dicionário Universal de Letras”45.

Essa noção de "plágio por antecipação” surge em tom de manifesto, para que os oulipianos defendessem sua proposta em torno de uma escrita técnica e lúdica. No entanto, apesar de ter surgido num grupo restrito e com a função específica de nomear (e valorizar, por que não?) a prática de escrita a partir da recriação, essa noção será interessante para refletir sobre (e problematizar) o que está em jogo nas práticas de leitura.

Caracterizando-se como uma noção muito mais subjetiva do que a de intertextualidade e a de reescritura, o plágio por antecipação coloca algumas questões essenciais sobre a relação entre os textos e o leitor, sobre a formação do cânone e da história literária:

E se é legítimo preconizar uma história literária a contrapelo, é bem aquela da recepção das obras. Quem lê o quê primeiro? Quais textos se encontram propostos como prioridade aos jovens leitores nos manuais escolares? Como se constitui a história da literatura no espírito do leitor francês? ${ }^{46}$

\footnotetext{
44 "Il nous arrive parfois de découvrir qu’une structure que nous avions crue parfaitement inedite, avait déjà été découverte ou inventée dans le passé, parfois même dans un passé lointain. Nous nous faisons un devoir de reconnaître un tel état de choses en qualifiant les textes en cause de 'plagiats par anticipation'. Ainsi justice est rendue et chacun reçoit-il selon ses mérites.” Cf. o segundo manifesto, de 1973, de François Le Lionnais em OULIPO, 2003, p. 23, grifos meus.

45 “La liste que l'Oulipo entreprend de dresser de ses 'plagiares par anticipation' a toutes les chances de finir par constituer un nouveau Dictionnaire Universel des Lettres." Cf. "Histoire du lipogramme", de Perec, em OULIPO, 2003, p. 76

46 “Et s'il est légitime de prôner une histoire littéraire à rebours, c'est bien celle de la réception des œuvres. Qui lit quoi en premier? Quels textes se trouvent proposés en priorité aux jeunes lecteurs dans les manuels scolaires? Comment se constitue l'histoire de la littérature dans l'esprit du lecteur français?” (MAUREL-INDART, 2009, Não paginado)
} 
O reconhecimento do "plágio” de um escritor anterior está ligado ao sentimento de déjà-lu, ou seja, de já ter visto aquela ideia, aquele verso ou aquela frase em algum outro $\operatorname{lugar}^{47}$. É o caso, por exemplo, de reconhecermos essa noção de “plágio por antecipação” em Borges que, em 1951, já propõe uma inversão da ideia de precursor, defendendo que cada escritor cria seus próprios precursores a partir da análise de Kafka:

O fato é que cada escritor cria seus precursores. Seu trabalho modifica nossa concepção de passado, assim como há de modificar o futuro. Nessa correlação nada importa a identidade ou a pluralidade dos homens. (BORGES, 2007, p. 130)

Na ficção, podemos lembrar como Perec ficcionaliza a noção de plágio por antecipação no personagem Hugo Vernier, do conto de Le Voyage d'Hiver (1979), que narra a história de um livro (homônimo ao conto) de autoria desse escritor, o qual teria citado trechos de escritores posteriores, ou seja, seria um “plagiador por antecipação”:

Lera corretamente: isso queria dizer que Vernier havia "citado" um verso de Mallarmé com dois anos de antecipação, plagiado Verlaine dez anos antes de suas "Pequenas árias esquecidas", escrito versos de Gustave Kahn cerca de um quarto de século antes dele! (PEREC, 2005, p. 79, grifos meus)

Mas as coisas não podem ser tão simples assim, sobretudo nos textos de Georges Perec, que desafiam constantemente os leitores iniciados ou não. Nesse sentido, acredito que textos como o dele requisitam um esforço de ampliar o olhar para além dessas noções que buscam explicações, por vezes científicas, redutoras da relação entre os textos. Um exemplo profícuo desse esforço é a dissertação de Samira Murad, que procurou estabelecer uma nova metodologia de análise do conto Le Voyage d'Hiver com base na teoria do efeito estético de Wolfgang Iser. Com um enfoque diferente do que apresento aqui, a pesquisa de Murad $(2007)^{48}$ dialoga com minha proposta de leitura entre Perec e Flaubert uma vez que a

\footnotetext{
${ }^{47}$ Cf. o artigo “Un cas précis de 'plagiat par anticipation’”, de Benoît Delaune (2009, Não paginado) sobre o caso de Artaud, que reconhece um poema seu enquanto traduz Lewis Carroll.

${ }^{48}$ Para defender seu argumento, a pesquisadora percorre a crítica perecquiana ligada à questão do papel do leitor, entre ela: Claudette Oriol Boyer, que analisou os desdobramentos do uso da citação por Perec no conto de 1979; Claude Burgelin, que destacou o papel da impli-citação na obra do escritor, mostrando como Perec manipula e inscreve elementos de sua própria vida nas obras; e Hugues Corriveau, que defende o efeito de decepção dos textos perecquianos pela perspectiva de seus personagens. Para Murad, "Os problemas na análise de Boyer não estão na afirmação de que Le Voyage d'hiver estimula a criatividade do leitor, mas começam quando a autora assume que a restrição formal (a citação) é o elemento principal de interação com o leitor na construção do jogo que se dá entre esse e o texto. [...] Somente um leitor especializado poderia fazer ressoar o sentido nos mais variados níveis do texto, já que muitas dessas camadas estariam fora do alcance do leitor comum ou, pelo menos, pediriam uma 'longa colaboração'. É preciso, portanto, alargar a maneira como a crítica vê o jogo que se
} 
pesquisadora mostra como o jogo entre texto e leitor vai além do foco sobre os procedimentos formais e depende também da sedução do leitor. O próprio escritor, Georges Perec, menciona a questão da sedução do leitor no seguinte trecho de uma entrevista sobre o projeto oulipiano:

[...] através do Oulipo, graças à existência do Oulipo, ocorreu um tipo de tomada de consciência do que se podia fazer. Escrever, de uma certa forma, é sempre pegar o dicionário - quer dizer, o reservatório da língua e da sintaxe, e todas as tradições romanescas e poéticas - e tentar fazer alguma coisa diferente... alguma coisa que difere um pouco do que existia antes. É sempre, com certeza, o mesmo tipo de história, o mesmo tipo de descrição, e o mesmo tipo de ação e de narrativa. Apenas tentamos reforçar o que se passa entre o escritor e o leitor, a saber, o texto. Quero dizer que o texto funciona somente se o leitor o lê e que é preciso, portanto, seduzi-lo... ${ }^{49}$

Antes de entrarmos no texto, convido o leitor a ser seduzido também pelas regras e artimanhas que movimentam um mundo de livros em LVME. Para isso, vamos conhecer o Cahier des Charges de La Vie mode d'emploi, um conjunto de manuscritos fac-similados da fase preparatória do romance.

\section{O prédio assombrado de La Vie mode d'emploi: "planta e memorial descritivo”}

Vestígios do processo de composição de LVME podem ser conferidos no Cahier des Charges de La Vie mode d'emploi. Essa obra, publicada em 1993, não contempla os manuscritos da fase redacional (de 1975 a 1978) e os documentos da fase pré-editorial (texto passado a limpo, versão datiloscrita e provas corrigidas pelo escritor) - os quais também não serão tratados aqui -, mas podem ser encontrados na Biblioteca do Arsenal, em Paris.

No Cahier, encontramos o caderno Citations (Citações), no qual Perec coloca o nome de cada escritor que ele pretende citar em seu livro, seguido por uma lista numerada de 1 a 10 com o título da obra, a página a ser citada e ainda o capítulo do LVME que receberá a citação. Além disso, há o caderno Allusions \& Détails (Alusões e Detalhes) e o próprio Cahier des

estabelece entre texto e leitor, o que significa não restringi-lo à citação, impli-citação ou decepção como pontos privilegiados de comunicação.”(MURAD, 2007, p. 37)

49 “[...] à travers l’Oulipo, grâce à l'existence de l'Oulipo, il y a eu comme une prise de conscience de ce qu'on pouvait faire. Écrire, dans un certain sens, c'est prendre le dictionnaire - c'est-à-dire ce reservoir de la langue et de la syntaxe, et toutes les traditions romanesques et poétiques - et essayer d'en faire quelque chose d'autre... quelque chose qui diffère un peu de ce qui existait avant. C'est toujours, bien sûr, le même type d'histoire, le même type de description et le même type d'action et de récit. Nous avons seulement essayé de renforcer ce qui se passe entre écrivain et lecteur, à savoir le texte. Je veux dire que le texte fonctionne seulement si le lecteur le lit et qu'il faut donc séduire celui-ci...”. (PEREC, 2003b, p. 256) Cf. a entrevista “The doing of fiction”, propos recueillis par Kaye Mortley le 24 août 1981, à Paris. Transcription et traduction de Mireille Ribière. 
Charges do qual cada página (Figura 1) apresenta uma lista de elementos que compõe cada capítulo:

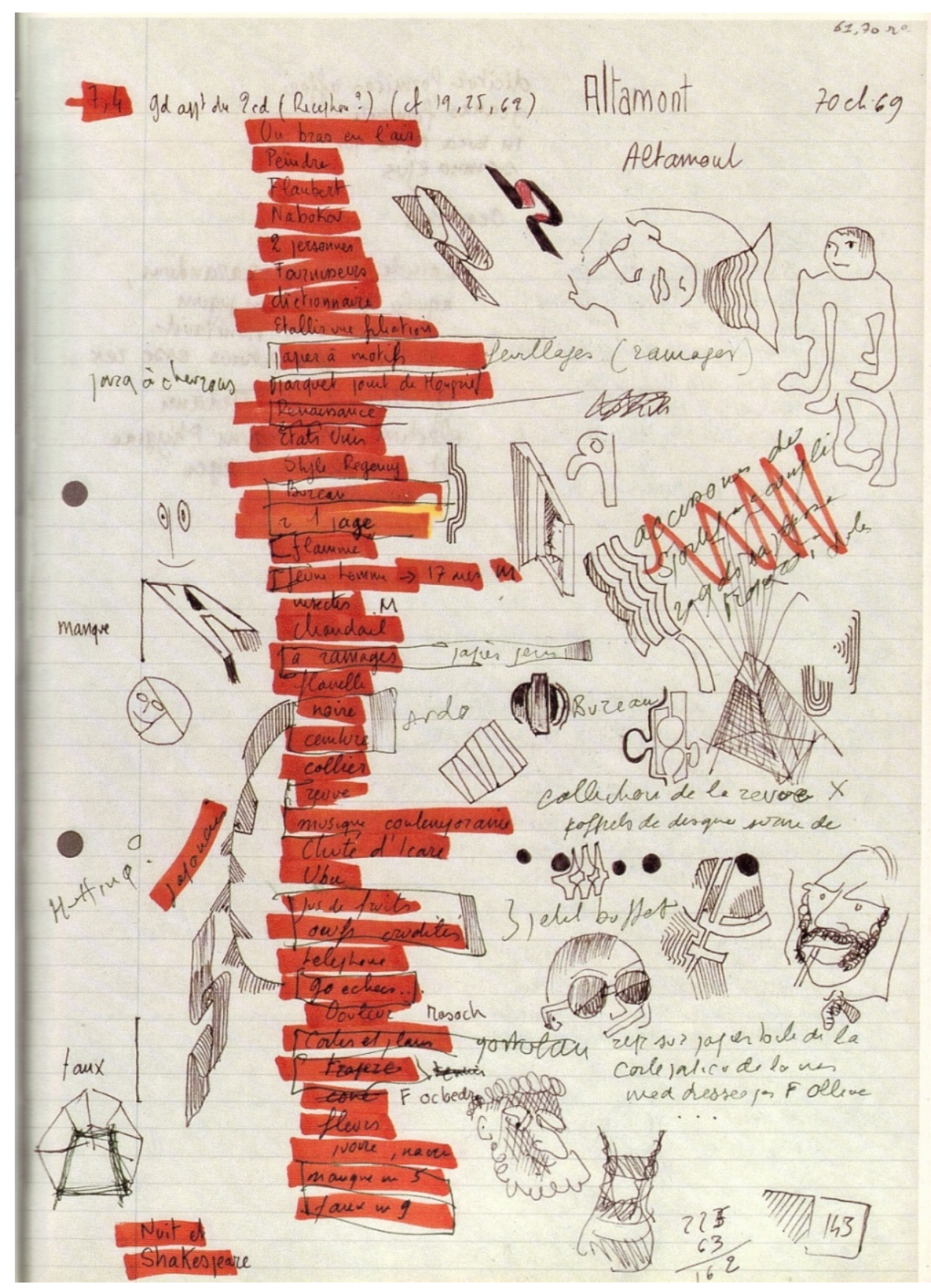

Figura 1. Exemplo da lista feita por Perec para compor o capítulo 69. Altamont, 4 presente no Cahier de Charges de La Vie mode d'emploi, Paris: CNRS, 1993.

Por meio do Cahier, é possível conhecer diversos procedimentos da composição desse romance plural. A poligrafia do cavalo do xadrez (Figura 2), a pseudoquenina de ordem 10 e o bi-quadrado latino são os mais conhecidos. O emprego desses procedimentos matemáticos visa à obtenção do percurso do imóvel por meio de um modelo formal e ao princípio de exaustividade e de não repetição dos elementos que compõem cada lista de cada capítulo. A 
movimentação do cavalo no tabuleiro determina a ordem dos capítulos de $L V M E$ a partir de um modelo formal, não de uma movimentação “real”. Esse modelo formal consistia em movimentar a peça do cavalo no tabuleiro com 63 saltos consecutivos, em L, de acordo com as regras de xadrez, sem repetição ou omissão de casas. O percurso determinaria também a ordem na qual seriam descritos os cem apartamentos do prédio e fixaria também a ordem dos capítulos do romance, já que cada capítulo corresponde à descrição de um cômodo.

Além disso, essa trajetória define a divisão do romance em seis partes, já que cada vez que o cavalo passa pelas quatro bordas do tabuleiro começa uma nova parte do romance. Porém, o escritor infringe a própria regra a que submeteu sua escritura e pula o movimento de número 66, em que o cavalo pararia num porão (casa inferior esquerda do tabuleiro), descrevendo a peça referente ao $67^{\circ}$ movimento, a saber, a butique da Mme Marcia. Assim, o romance não terá 100 capítulos, como era previsto pela regra, mas 99.

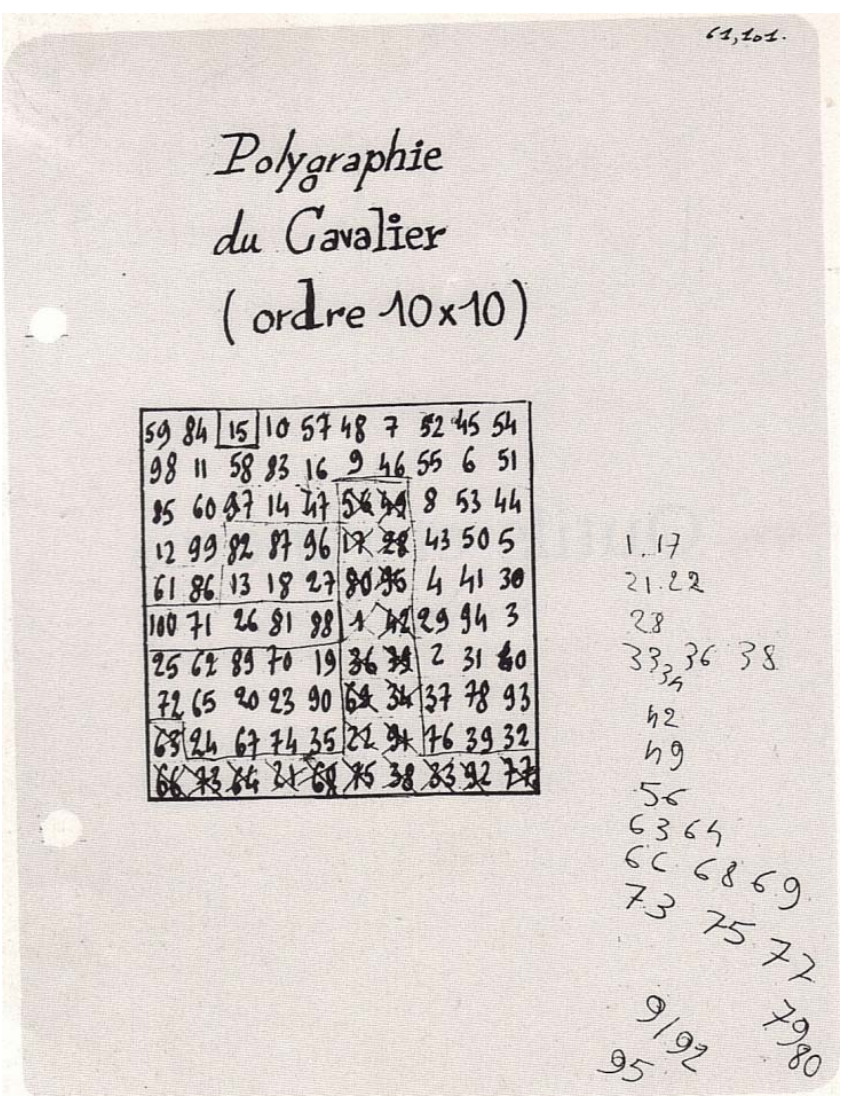

Figura 2. Poligrafia do cavalo presente no Cahier de Charges de La Vie mode d'emploi, Paris: CNRS, 1993. p. 40.

A aplicação de saberes matemáticos não é exclusiva de Georges Perec. Ela é utilizada por muitos membros do Oulipo: Calvino, que entrou no grupo em 1970, também utilizou propostas combinatórias em Se um viajante numa noite de inverno e Castelo dos 
Destinos Cruzados. Os membros do grupo dedicavam-se à pesquisa de recursos lógicomatemáticos, matrizes, jogos de xadrez, I Ching, tarô, formas poéticas de trovadores provençais, entre outros. A música também era utilizada como recurso composicional: Raymond Queneau, um dos fundadores do grupo na década de 1930, criou seus Exercícios de estilo a partir das Fugas de Bach.

O quebra-cabeça também se revela uma imagem importante da composição de $L V M E$ e aparece no romance publicado, por exemplo, no Preâmbulo, em que há uma teoria do jogo, e na construção do personagem Bartlebooth, criador de quebra-cabeças. Por meio da imagem desse jogo, Perec já denuncia seu trabalho com elementos (peças) prontos(as) ${ }^{50}$.

Diante de tantas regras e fórmulas para compor o romance, é possível questionar se as 99 listas de elementos presentes no Cahier des Charges seriam a imposição de um limite à criação literária. Ao longo do livro, a resposta encontrada é que a invenção narrativa escapa aos elementos indicados:

A partir disso [dos programas], inseria no livro tudo o que queria contar: tanto histórias verdadeiras como histórias falsas, passagens de erudição completamente inventadas, outras escrupulosamente exatas. O livro se tornou uma verdadeira máquina de contar histórias, assim como algumas histórias possuem três linhas, outras se expandem em vários capítulos. ${ }^{51}$

A lógica da estrutura é premeditada nas listas, porém, ela não se impõe à lógica da ficção. Segundo Calvino (1990, p. 136), “o milagre é que essa poética que se poderia dizer artificiosa e mecânica dá como resultado uma liberdade e uma riqueza inventiva inesgotáveis”, pois Perec subverte várias das regras de seu manual, por meio de transformações semânticas, linguísticas, tipográficas ou mesmo escondendo algumas dessas restrições. Bernard Magné (1990) define as listas presentes nesse caderno como um léxico, um dicionário, signos que serão trabalhados de diversas maneiras no texto, ou que sequer poderão ser encontrados no texto final ${ }^{52}$. Alguns dos elementos que compõem as listas do Cahier des Charges já apontam para o desvirtuamento do jogo perecquiano. Exemplo disso

\footnotetext{
${ }^{50}$ Claudia A. Pino indica como essa figura do quebra-cabeça aponta para a dessacralização da imagem do autor como ser inspirado que parte da página em branco: “Ao armar um quebra-cabeça, partimos de peças já prontas: não é possível dizer que compomos um mundo a partir do nada.” (PINO, 2007, p. 86)

51 "À partir de là, je faisais entrer dans le livre tout ce que je voulais raconter: des histoires vraies comme des histoires fausses, des passages d'érudition complètement inventés, d'autres qui sont scrupuleusement exacts. Le livre était devenu une véritable machine à raconter des histoires aussi bien des histoires qui tiennent en trois lignes que d'autres qui s'étalent sur plusieurs chapitres. " (PEREC, 2003a, p. 243-4) Cf. a entrevista "La maison des romans", propos recueillis par Jean-Jacques Brochier, Le Magazine Littéraire, n 141, "Nietzche”, octobre 1978.

${ }^{52}$ MAGNÉ, B. Du register au chapitre: le 'cahier des charges' de La Vie mode d'emploi de Georges Perec. In: NEEFS, J.; DIDIER, B. 1990, p. 187-192
} 
são as restrições: MANQUE (falta), que indica a eliminação de algum elemento (já apontado na mesma lista) da redação final do capítulo, e FAUX (falso), que aponta, na redação final, qual elemento da lista será trocado ou alterado por um outro.

De acordo com Claudia A. Pino, além de as listas perecquianas aniquilarem a função mítica da página em branco, elas servem como um manual de "descriação", ou melhor, de subversão ${ }^{53}$, permutação, transformação, como mostram diversas análises genéticas de LVME. A própria pesquisadora (PINO, 2007, p. 85-7) exercita essa leitura de um capítulo do romance ao lado da página correspondente no Cahier de Charges, mostrando como Perec retira alguns elementos narrativos do Capítulo 31 de LVME do romance policial O caso dos dez negrinhos, de Agatha Christie. Ela aponta também uma transformação lexical no Capítulo 89: a atividade “entrar” proposta na lista do manuscrito transforma-se, na redação final, no sobrenome do personagem Louis Commine, pela transformação da expressão verbal “come in”, do inglês, em um nome próprio. Já Bernard Magné propõe inclusive uma tipologia das transformações propostas por Perec a partir do cotejamento do capítulo 36 com a página correspondente do Cahier des Charges: transformações semânticas, diegéticas, metadiegéticas, linguísticas e tipográficas. Um estudo mais amplo e cuidadoso sobre a composição de $L V M E$ foi feito por Danielle Constantin (2008, p. 81-122), que analisa diversos documentos pré-textuais para mostrar como Perec deu conta do conflito discursivo e enunciativo que esse romance apresentava no momento de sua composição por meio da escolha de uma voz narrativa ambígua e coletiva (“nous”), colocando, assim, o leitor em seu jogo de escrita.

O leitor possui um papel já previsto pelo escritor em seu romance, porém, o desejo de Perec é de que o leitor vá além do previsível e faça o romance a seu modo, como deixa transparecer na seguinte entrevista concedida no ano de publicação de LVME:

\footnotetext{
${ }^{53}$ A subversão à regra é chamada pelos oulipianos de clinamen. Trata-se de erro que é incluído no sistema para que este funcione com mais liberdade. O conceito, segundo Perec, é emprestado de Alfred Jarry, poeta e patafísico, que retomou o termo da teoria do movimento dos átomos proposta por Epicuro: "Chaque fois qu'on veut appliquer rigidement un système, il y a quelque chose qui coince. Pour qu'on puisse fonctionner dedans avec liberté, il faut introduire volontairement une petite erreur. On connaît la phrase de Klee: 'Le génie, c'est l'erreur dans le système'. C'est cette intervention que les Oulipiens, et avant eux Jarry, appellent le clinamen. La petite erreur, qui nous vient de Lucrèce, et sans laquelle aucun atome n'accrocherait les autres, sans laquelle donc le monde n'existerait pas." (PEREC, 2003a, 240-1) Cf. a entrevista "La maison des romans", propos recueillis par Jean-Jacques Brochier, Le Magazine Littéraire, n. 141. Em outra entrevista, Perec retoma esse conceito para explicar como trapaceia no próprio jogo de sua escrita: "Pour qu'il y ait jeu, il faut qu'il y ait règle. C'est une banalité, mais qui en dit long... Pour parler du tricheur, je peux vous parler de ce que je fais continuellement dans mon jeu d'écriture. Je m'impose des règles pour la construction de mon livre, qui sont souvent extrêmement difficiles, et quand je ne réussis pas à les suivre, je 'triche' et j'appelle ça un clinamen. [...] Au début, il faut un petit quelque chose pour que les atomes se touchent, pour que le système devienne dynamique. Il appelait ça le clinamen. Ensuite, il a donné ce nom à la petite distorsion dans la règle qui fait que la règle fonctionne." (PEREC, 2003a, p. 281) Cf. a entrevista "La vie: règle du jeu”, propos recueillis par Alain Hervé, Le Sauvage (Le Nouvel Observateur-Écologie), n. 60, “Le jeu”, décembre 1978.
} 
Uma forma de balanço romanesco de vinte anos de trabalho... É o livro potencial. Gostaria que depois de tê-lo terminado, o leitor retome-o, brinque com ele, invente a seu modo. É assim que muitas histórias são "reservadas", não explicitadas, e que subsistem enigmas, parecidos com as peças que faltam em um quebra-cabeça. ${ }^{54}$

Nessa declaração, Perec já aponta para um modo de ler LVME que não se caracteriza como um mero “jogo de salão”. O trabalho com as contraintes pode ser considerado antes um exercício de escrita particular, uma investigação das potencialidades de escrita, do que um jogo com o leitor. Isso porque a grande maioria dos leitores de Perec não lerá $L V M E$ com o Cahier des Charges ao lado para consultar e tentar desvendar enigmas do processo de redação das narrativas presentes no romance (como se o Cahier fosse um manual do jogo). O efeito desse jogo de potencialidades no trabalho de escrita reflete-se nas potencialidades de leitura, no desejo do leitor de prolongar aquele romance, de, como em uma receita, colocar seu tempero, mudar os ingredientes para deixar o prato à sua moda. Alguns anos após a publicação de $L V M E$, Perec vai comentar os relatos de leitores de seu romance mostrando esse efeito de leitura potencial:

... não tenho a impressão de que meus livros possuam um sentimento de gratuidade, ou apenas de gratuidade, que eles sejam apenas máquinas. Tive a impressão de que há alguma coisa por trás [...] que são, posso dizer, muito profundas. Eu sei por conta de, por conta de algumas... numerosas reações que pude pessoalmente registrar com La Vie mode d'emploi, ou com $\mathrm{La}$ Disparition... Bem, La Disparition é um exercício, o que chamamos de façanha. Mas La Vie mode d'emploi, as pessoas... tiveram vontade de me contar histórias depois de terem lido esse livro. Enviaram-me histórias depois de terem lido esse livro. Enviaram-me histórias... de uma dama que tinha feito a volta ao mundo pintando aquarelas, uma história de um famoso senhor que colecionava pedras em Grenoble. Enviaram-me pastiches. Tiveram vontade de me escrever e de contar coisas. Então, manifestamente, é que... acharam, a princípio, que não haviam lido o livro como um simples jogo de salão e, em seguida, encontraram alguma coisa que, posso dizer, matava um pouco sua sede de romanesco, sua necessidade de ficção e necessidade que a gente tem... de contar histórias para os outros..."

\footnotetext{
54 “Une sorte de bilan romanesque de vingt ans de travail... C’est le livre potentiel. Je voudrais qu'après l'avoir terminé, le lecteur le reprenne, joue avec lui, invente à son tour. C'est ainsi que beaucoup d'histoires sont 'reservées', non explicitées, et que subsistent des énigmes, pareilles aux pièces manquants d'un puzzle.” (PEREC, 2003a, p. 255-6) Cf. a entrevista “Georges Perec: le grand jeu”. Propos recueillis par Francine Ghyse, Femmes d'aujourd'hui, Bruxelles, 14-20 novembre 1978.

55 “... je n’ai pas l'impression que mes livres donnent un sentiment de gratuité, ou seulement de gratuité, qu’ils soient seulement des machines. J'ai l'impression qu'il y a quelque chose derrière [...] qui sont, je peux dire très profondes. Je sais d'après, d'après les quelques... les nombreuses réactions que j'ai pu personnellement enregistrer avec La Vie mode d'emploi, ou avec La Disparition... Bon, La Disparition est un exercice, ce qu'on appelle un tour de force. Mais La Vie mode d'emploi, des gens... ont eu envie de me raconter des histoires après avoir lu ce livre. Ils m’ont envoyé des histoires après avoir lu ce livre. Ils m’ont envoyé des histoires... d’une dame qui avait fait le tour du monde en peignant des aquerelles; une histoire d'un fameux monsieur qui collectionnait des cailloux à Grenoble. Ils m’ont envoyé des pastiches. Ils ont eu envie de m’écrire et de me
} 
As potencialidades de escrita aliadas à multiplicidade de narrativas presentes em LVME permitiram uma via de análise da obra de Georges Perec pela noção de hipertexto do campo da informática. Diferente da noção de hipertextualidade defendida por Genette, em Palimpsestes, definida como transformação e imitação de um texto base, a noção de hipertexto elaborada por estudiosos das tecnologias digitais foi tomada por Pablo Martín Sánchez (2011, p. 1-12) para ler o projeto estético oulipiano e especificamente algumas obras perecquianas. Trata-se de um conceito formulado inicialmente pelo filósofo norte-americano Theodor Nelson ${ }^{56}$, em 1965, e desenvolvido pelo professor George Landow ${ }^{57}$, em 1992, que mescla questões de tecnologia com crítica literária, privilegiando a rede como imagem da leitura de alguns textos característicos por apresentar "uma escritura não sequencial, um texto que bifurca, um leitor que escolhe o modo de conectar os diferentes fragmentos de texto e, consequentemente, a existência de diferentes percursos de leitura possíveis. „58

Em seu artigo, Sánchez caracteriza LVME como um texto pseudo-hipertextual, cuja leitura oferece ao leitor o efeito de leitura hipertextual, ou seja, a possibilidade de ler o romance (ou os romances, como indica o subtítulo) em diferentes direções, mas que apresenta uma sequência linear também e não impõe diversos percursos de leitura. Essa imposição de uma leitura rizomática, condição essencial do hipertexto, está presente, por exemplo, em “Un conte à votre façon”59, de Raymond Queneau, um texto inspirado em instruções próprias da linguagem computacional, que faz o leitor decidir seu percurso de leitura a partir das respostas a determinadas perguntas propostas pelo narrador. Outro exemplo seria o inacabado projeto

raconter des choses. Donc, manifestement, c’est ce... ils avaient trouvé d’abord qu'ils n’avaient pas lu le livre comme un simple jeu de salon, et ensuite ils y avaient trouvés quelque chose qui, je peux dire, assouvissait un peu leur soif de romanesque, leur besoin de fiction et le besoin qu'on a... qu'on vous raconte des histoires..." (PEREC, 2003b, p. 289-290) Cf. a entrevista "Discussion sur la poésie”. Lecture de poèmes et discussion sur la poésie à l’Alliance Française de Melbourne, le 6 octobre 1981. (Transcription de Heather Mawhinney).

56 Ted Nelson, como é conhecido, cunhou o termo hipertexto e concebeu o inacabado projeto Xanadu, uma ferramenta que daria acesso a textos (inclusive literários) em rede. Para mais informações, acesse: <http://www.ibiblio.org/pioneers/nelson.html> Acesso em 17 jan. 2012.

${ }^{57}$ Georges Landow é um dos grandes teóricos dedicados aos conceitos de hipertexto e hipermídia.

58 “une écriture non séquentielle, un texte qui bifurque, un lecteur qui choisit la façon de connecter les différentes fragments de texte et, par conséquent, l'existence de différents parcours de lecture possibles.” (SÁNCHEZ, 2011, p.2)

59 "Un conte à votre façon" foi apresentado por Queneau na 83 ${ }^{\mathrm{a}}$ reunião do Oulipo. Cf. o texto em OULIPO, 2003, p. 273-277. Trata-se, inclusive, de uma proposta muito semelhante à de Julio Cortázar em Jogo da Amarelinha (1963) e à da coleção de textos infantojuvenis "Enrola e desenrola”, que fez muito sucesso no Brasil, nos anos 1980. Sobre o livro de Cortázar, é preciso dizer que Perec, leitor da versão francesa Marelle, não o considerava propriamente hipertextual, pois não considerava a história descontínua uma proposta que dependesse exclusivamente do leitor: “[...] Julio Cortázar, dans La Marelle [sic], suggère deux lectures d’un même récit, l'une linéaire, l'autre discontinue, mais c'est un discontinu orienté une fois pour toutes, et non un véritable choix." (PEREC, 2003a, p. 102) Cf. a entrevista "Écriture et mass-media”. Preuves, n. 202, décembre 1967. 
L’Arbre, de Georges Perec, que contaria a história da família do escritor a partir da estrutura de sua árvore genealógica.

As noções de hipertextualidade e pseudo-hipertextualidade analisadas por Sánchez se restringem à leitura de um só livro, ou seja, refletem apenas sobre os percursos de leitura possíveis em um tomo, sem lançar as redes para as demais obras de um escritor ou entre esse escritor e outros. Por isso, não são utilizadas aqui para justificar a leitura da obra de Perec em relação a outros escritores. Mesmo assim, as imagens do rizoma e, propriamente, a da rede (de computadores ou a própria Web) abrem a possibilidade de se pensar os modos (novos? ${ }^{60}$ ) de se relacionar livros.

Essa imagem da rede também é evocada por Calvino (1990, p.115-138), na conferência "Multiplicidade" 61 , para defender sua ideia de hiper-romance, que reúne as seguintes características: voz e tempo multíplices e ramificados, "escrita breve” (mesmo em romances extensos) e que, em diferentes níveis, se debruça sobre a questão do conhecimento como multiplicidade:

[...] os livros modernos que mais admiramos nascem da confluência e do entrechoque de uma multiplicidade de métodos interpretativos, maneiras de pensar, estilos de expressão. Mesmo que o projeto geral tenha sido minuciosamente estudado, o que conta não é o seu encerrar-se numa figura harmoniosa, mas a força centrífuga que dele se liberta, a pluralidade das linguagens como garantia de uma verdade que não seja parcial. (CALVINO, 1990, p. 131)

É justamente isso que encontro na leitura de Perec e, sobretudo, em LVME: deparome, por um lado, com um projeto milimetricamente calculado (e burlado) que procura refletir sobre as potencialidades da linguagem e a multiplicidade de elementos que compõem a própria vida (livros, coisas e “causos”). Por outro lado, tenho um livro que oferece várias histórias do presente, do passado e do futuro dos personagens que habitam os apartamentos do edifício, além de me permitir escolher outros percursos de leitura (escolhendo títulos no index

\footnotetext{
${ }^{60}$ Esta é uma questão, pois as práticas de escrita que privilegiam o fragmentário parecem remontar ao século XVIII, como afirma Perec em uma conferência sobre escritura e mídia de massa (como pode ser considerada a Internet hoje): "Les modèles du discontinu multiplient les pouvoirs de l'écriture; on aurait tort d'oublier qu'ils en multiplient également les contraintes: la stéréographie, les inventions typographiques, les variations de mise en pages, les choix rendus possibles par la présence concurrente et simultanée de plusieurs niveaux de lecture n’ont de chance d'être efficaces que s'ils se constituent en système. [...] Car - ce n'est pas un dernier paradoxe - le vrai modèle de ces oeuvres n'appartient ni au montage cinématographique, ni à la mise en pages des magazines, ni même aux bandes dessinés, mais bel et bien aux romans du XVIIIe siècle, à Melmoth, aux Liaisons Dangereuses, à Jacques le fataliste, à Tristram Shandy enfin et surtout; nous n'avons pas à nous en étonner: de ces oeuvres sont sortis les feuilletons, et des feuilletons les bandes dessinées.” (PEREC, 2003a, p. 103)

${ }^{61}$ Esta conferência foi a última de seis previstas por Ítalo Calvino para as Norton Lectures. O escritor faleceu antes de escrever a conferência intitulada "Consistência”, e tinha ideia para mais duas além das programadas.
} 
presente no final do livro) e reconhecer algumas referências externas a outros escritores, seja por um sentimento de déjà lu, seja por indicações explícitas, como esta no pós-escrito:

(Ce livre comprend des citations, parfois légèrement modifées de: René Belletto, Hans Bellmer, Jorge Luis Borges, Michel Butor, Italo Calvino, Agatha Christie, Gustave Flaubert, Sigmund Freud, Alfred Jarry, James Joyce, Franz Kafka, Michel Leiris, Malcolm Lorry, Thomas Mann, Gabriel García Marquez, Harry Mathews, Herman Melville, Vladimir Nabokov, Georges Perec, Roger Price, Marcel Proust, Raymond Queneau, François Rabelais, Jacques Roubaud, Raymond Toussel, Stendhal, Laurence Sterne, Théodore Sturgeon, Julio Verne, Única Zürn.). ${ }^{62}$ (LVME, p. 636)

Esse livro forma, portanto, uma grande rede de relações com os escritores citados acima, rede essa que se emaranha com os elementos que Perec listou para cada capítulo, com seus procedimentos de escrita, com a cultura de sua época e também com cada leitor: que possui outras tantas referências pessoais, culturais e de leitura. É por tudo isso que Calvino considera $L V M E$ “o último verdadeiro acontecimento na história do romance”63, mas antes disso, ele cita uma série de escritores que também trabalham com essas redes entre histórias, pessoas e coisas, cujo paradigma, no gênero romanesco, parece ter sido estabelecido por Flaubert em seu BP:

Bouvard et Pécuchet é o arquétipo dos romances que hoje passo em revista, mesmo se a patética e hilariante travessia do saber efetuada por esses dois quixotes do cientificismo do séc. XIX se apresenta como uma sucessão de naufrágios, mas são mundos que se excluem mutuamente, ou que com suas contradições destroem toda possibilidade de certeza. (CALVINO, 1990, p. 128-9)

Dando um passo atrás na cronologia e um passo à frente no capítulo, saímos do prédio perecquiano repleto de fantasmas para entrar no universo de livros movimentados por Flaubert em seu derradeiro romance. Nesse movimento, tentarei explicitar o fenômeno de biblioteca proposto por Foucault e mostrar como essa noção me permite ler Perec e Flaubert em relação.

\footnotetext{
62 "(Este livro contém citações, às vezes ligeiramente modificadas de [...])". Conforme indicado na Lista de abreviaturas, na página 9 desta dissertação, apenas as citações de $L V M E$ e de $B P$ serão mantidas em francês no corpo do texto e serão traduzidas nas notas de rodapé.

63 “E isto por vários motivos: o incomensurável do projeto nada obstante realizado; a novidade do estilo literário; o compêndio de uma tradição narrativa e a suma enciclopédica de saberes que dão forma a uma imagem do mundo; o sentido do hoje que é igualmente feito com acumulações do passado e com a vertigem do vácuo; a contínua simultaneidade de ironia e angústia; em suma, a maneira pela qual a busca de um projeto estrutural e o imponderável da poesia se tornam uma coisa só.” (CALVINO, 1990, p. 135)
} 


\section{Um mundo cheio de livros: o romance envenenado de Flaubert}

Ao longo de seis anos e mais de 2400 folios, Flaubert dá forma (vida) a BP, seu último projeto, o qual tinha a pretensão de ser cômico e, na verdade, acabou se tornando irônico, já que o escritor morreu em pleno trabalho em maio de 1880, deixando os personagens copiando eternamente. O “romance” cujo tema é a "revisão de todas as ideias modernas” acabou devorando ${ }^{64}$ o escritor incansável.

A ideia de escrever uma enciclopédia da estupidez humana começa a adquirir contorno após a publicação de Salammbô, entre 1862 e 1863, mas é após a finalização da terceira versão de A Tentação de Santo Antão que o escritor coloca o projeto no papel já indicando o trabalho de pesquisa intenso que deverá empreender:

Estou tão avesso a tudo que não quero mais publicar. Para quê? Por quê? Vou começar um livro que vai me ocupar durante muitos anos. Quando ele terminar, se os tempos forem mais prósperos, eu o lançarei ao mesmo tempo que [A tentação de] Santo Antão. É a história desses dois homenzinhos que copiam uma espécie de enciclopédia crítica em farsa. Você talvez saiba do que se trata. Para isso, será necessário estudar muitas coisas que eu ignoro: química, medicina, agricultura. Agora estou na medicina. Mas é preciso ser louco e triplamente frenético para desenvolver um livro desses! ${ }^{65}$

A lista de obras lidas, anotadas e compiladas parece não ter fim ${ }^{66}$ e demonstram o trabalho hercúleo de pesquisa que parece tornar o criador semelhante às criaturas (e viceversa) ${ }^{67}$, já que os dois tipos também entrarão na freneticidade da lógica enciclopédica,

\footnotetext{
${ }^{64}$ No Le Gaulois, de 6 de abril de 1881, Maupassant declara que Flaubert tinha receio de não terminar o livro: "Un livre pareil mange un homme, car nos forces sont limitées et notre effort ne peut être infini. Flaubert écrivit deux ou trois fois à ses amis: ' J'ai peur que la teminaison de l'homme n'arrive avant celle du livre - ce serait une belle fin de chapitre'.” (FLAUBERT, 1999, p. 473)

65 “Je suis si dégoûté de tout que je ne veux pas maintenant publier. À quoi bon? Pourquoi? Je vais commencer un livre qui va m’occuper pendant plusieurs années. Quand il sera fini, si les temps sont plus prospères, je le ferai paraître en même temps que Saint Antoine. C'est l'histoire de ces deux bonshommes qui copient une espèce d'encyclopédie critique en farce. Vous devez en avoir une idée. Pour cela, il va me falloir étudier beaucoup de choses que j'ignore: la chimie, la médecine, l'agriculture. Je suis maintenant dans la médecine. Mais il faut être fou et triplement frénétique pour entreprendre un pareil bouquin!”. Flaubert à Madame Roger des Genettes. Croisset, lundi 18 août 1872. Tradução e grifos meus. Todos os trechos da correspondência flaubertiana citados neste trabalho são da edição eletrônica organizada por Danielle Girard e Yvan Leclerc, disponível em : <http://flaubert.univ-rouen.fr/index.php>, conforme indicado na bibliografia.

${ }^{66}$ A lista de obras lidas entre 1872 e 1874 faz parte do Carnet 15, In: FLAUBERT, 1988, p. 460-530.

${ }^{67}$ Sobre isso, Borges (1989, p. 259 -60), em “Vindicación de Bouvard et Pécuchet” afirma que "El hecho es que cinco años de convivencia fueron transformando a Flaubert en Pécuchet y Bouvard o (más precisamente) a Pécuchet y Bouvard en Flaubert. Aquéllo, al principio, son dos idiotas, menospreciados y vejados por el autor, pero en el octavo capítulo ocurren las famosas palabras: 'entonces una facultad lamentable surgió en su espíritu,
} 
passando de um livro a outro, estudando temas desconhecidos, tornando-se, todavia, ainda mais curiosos e ansiosos em relação ao que ainda não sabem. Em pensar que o projeto original de Flaubert era compor Bouvard e Pécuchet em dois volumes ${ }^{68}$ !

O motor da escritura dessa "torre de Babel da ciência"69 é justamente a tolice (bêtise) humana diante dos saberes, isto é, as contradições e limitações presentes nos sistemas científicos, dos fatos, da crítica literária, da política e de tudo o que é "senso comum”. A estupidez incomoda tanto o escritor - como é possível comprovar ao longo de sua correspondência - que seu projeto pode ser considerado vingativo:

A tolice humana atualmente me oprime tanto que me dá a impressão de uma mosca carregando o Himalaia nas costas. Não importa! Vou me esforçar para vomitar meu veneno em meu livro. Esta esperança me conforta. ${ }^{70}$

Se a pesquisa é vingança, as palavras são veneno. Um veneno que causa dependência e consome aos poucos o escritor, os personagens e os próprios leitores diante de tamanho atestado da impotência humana em relação ao conhecimento. Maupassant (1881) descreve bem os efeitos desse veneno em Flaubert, de forma um pouco romanceada, é verdade, mas por que não transformá-lo também em personagem que sobe à prateleira da ficção?

Lá, em Croisset, em seu grande gabinete com cinco janelas, ele lamentava dia e noite sobre sua obra. Sem trégua, sem descansos, sem prazeres e sem distrações, com o espírito formidavelmente tenso, ele avançava com uma lentidão desesperante, descobrindo a cada dia novas leituras a fazer, novas pesquisas a começar. $\mathrm{E}$ a frase também o atormentava, a frase concisa, precisa, com cor ao mesmo tempo, que devia resumir em duas linhas um volume, em um parágrafo todos os pensamentos de um sábio. ${ }^{71}$

la de ver la estupidez y no poder, ya, tolerarla.' Flaubert, en este punto, se reconcilia con Bouvard y con Pécuchet, Dios con sus criaturas."

${ }^{68} \mathrm{O}$ segundo volume seria destinado à cópia de Bouvard e Pécuchet, denominado sottisier pela crítica. Desse volume só resta a fase preparatória e as opiniões dos críticos que publicaram as diferentes edições de Bouvard e Pécuchet se dividem no que diz respeito às partes que compõem esse volume (questão, por exemplo, do Album de La Marquise). Na edição de Claudine Gothot-Mersch (2009), o segundo volume é formado por citações sobre diversos livros e assuntos abordados no primeiro volume, l'Album de la Marquise, Le Dictionnaire des Idées Reçues e Le Catalogue des Idées Chic.

${ }^{69}$ Expressão usada por Maupassant no artigo de 1881.

70 "La bêtise humaine actuellement m'écrase si fort que je me fais l'effet d'une mouche ayant sur le dos l'Himalaya. N'importe! Je tâcherai de vomir mon venin dans mon livre. Cet espoir me soulage.” Flaubert à Edmond de Goncourt. Croisset, mardi, 9 octobre 1877. Grifos meus.

71 “Là-bas, à Croisset, dans son grand cabinet à cinq fenêtres, il geignait jour et nuit sur son oeuvre. Sans aucune trêve, sans délassements, sans plaisirs et sans distractions, l'esprit formidablement tendu, il avançait avec une lenteur désespérante, découvrant chaque jour de nouvelles lectures à faire, de nouvelles recherches à entreprendre. Et la phrase aussi le tourmentait, la phrase concise, si précise, colorée en même temps, qui devait 
Muitos críticos reforçaram a estupidez e o ceticismo estéril de Bouvard e Pécuchet, porém, Queneau (1985), no prefácio que escreveu para a edição Gallimard de 1950, defendeu os dois copistas, afirmando que suas experiências resultam da confiança abusiva e ingênua que ambos têm na escritura, de sua falta de espírito crítico e, acima de tudo, trata-se da “estupidez dos outros”. Nesse sentido, o foco da leitura deve estar na forma pela qual os saberes se organizam no livro, como denuncia o subtítulo Da falta de método nas ciências, empregado por Flaubert em 1879.

Seguindo essa leitura, a organização do romance não será feita a partir de eventos históricos ou de elementos da narrativa (estes últimos inseridos num segundo momento), mas através de listas e esquemas. Tornar romance o que, desde o início, se apresenta como uma enciclopédia parece ser o maior desafio desse projeto flaubertiano. A configuração dessa enciclopédia romanesca não é de ordem cronológica, mas de ordem espacial, como é possível observar na disposição dos saberes em forma de interrogação no seguinte trecho do roteiro gg 10, $\mathrm{f}^{\mathrm{o}} 69$ :

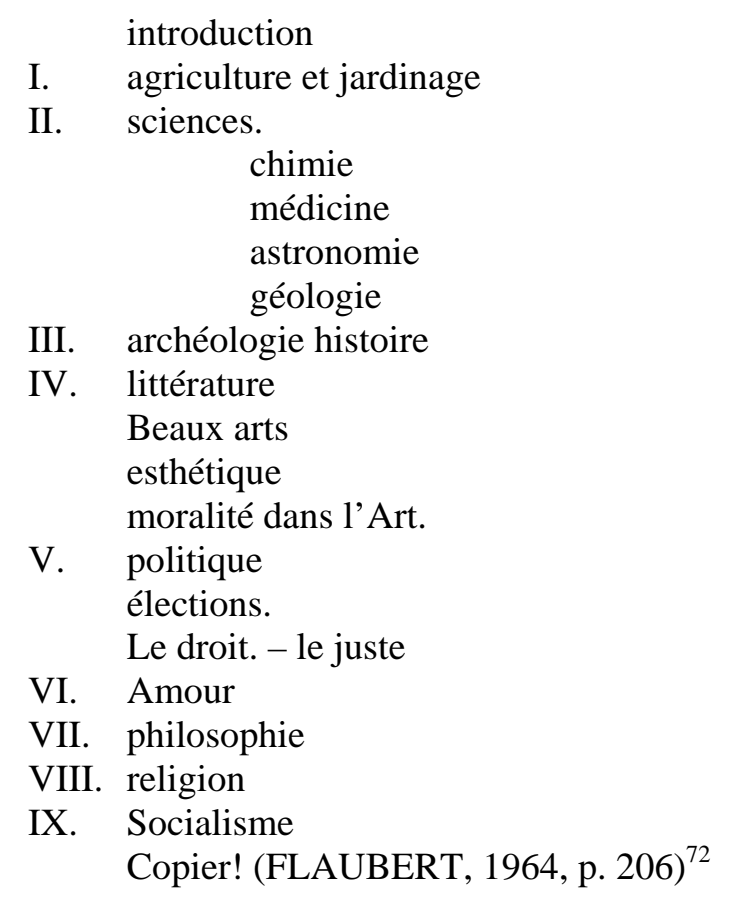

renfermer en deux lignes un volume, en un paragraphe toutes les pensées d'un savant.” Cf. Maupassant. In: FLAUBERT, 1999, p. 473.

${ }^{72}$ Este mesmo fragmento presente na edição de Bouvard et Pécuchet de Alberto Cento aparece na primeira página da introdução do livro de Norioki Sugaya (2010), colocando em evidência a forma interrogativa dessa lista. 
Nesse sentido, o romance flaubertiano também terá algumas contraintes: a forma de ponto de interrogação esboçada por essa lista de temas representa tanto o trabalho de pesquisa e de escritura de Flaubert no romance como a busca incessante dos personagens Bouvard e Pécuchet. É o “veneno” da dúvida que rege a pesquisa em diferentes níveis do livro.

Realizando uma leitura genética dos saberes médicos, Norioki Sugaya (2010) introduz seu livro Flaubert épistemologue com essa interrogação e expõe suas considerações sobre a estrutura tabelar do romance definida desde a origem, até a questão da ordem dos saberes nos manuscritos e das inconsistências próprias de um romance atemporal. A ordem dos temas que os personagens estudam é considerada mais ou menos arbitrária, conforme as modificações realizadas pelo escritor na fase pré-redacional ${ }^{73}$. No entanto, é destacada a permutabilidade essencial das disciplinas como fio condutor de Bouvard e Pécuchet. Entender esse fio é a questão para adentrar essa biblioteca de saberes e leituras.

Esse romance filosófico demanda, portanto, um novo tipo de leitura. Uma leitura mais interrogativa do que tranquila (entretenimento), movida por uma curiosidade extrema, que diverte, irrita e consome. Uma leitura difícil de desempacotar e que não quer a aventura, mas o veneno.

\section{Leia apenas se quiser se perder (numa biblioteca fantástica)}

O veneno da busca do conhecimento nos livros se espalha em $B P$ e vicia seus personagens na ânsia de pôr determinada teoria à prova, incorporando e repetindo discursos científicos que circulavam na época, movimentando uma extensa biblioteca:

Bouvard e Pécuchet são tentados diretamente pelos livros, por sua multiplicidade infinita, pela sucessão das obras no espaço cinzento da biblioteca; esta, em Bouvard, é visível, inventariada, nomeada e analisada. [...] Seus poderes, ela os possui apenas por sua existência - pela proliferação infinita do papel impresso. (FOUCAULT, 2006, p. 95) ${ }^{74}$

Nessa conhecida leitura de Foucault sobre o projeto literário de Flaubert a partir de $A$ Tentação de Santo Antão, ele mostra como a biblioteca é ficcionalizada na obra flaubertiana

\footnotetext{
73 “L'ordre selon lequel les deux bonshommes étudient tour à tour ces disciplines s'avère ainsi plus ou moins arbitraire. [...] Ce que nous suggèrent ces modifications et ces hésitations au cours de la phase avant-textuelle, c'est la permutabilité essentielle des disciplines entre elles et l'impossibilité intrisèque de fixer la disposition du tableau, malgré tous les efforts que le romancier a faits afin de trouver une configuration naturelle de l'encyclopédie romanesque.” (SUGAYA, 2010, p. 8)

${ }^{74}$ Utilizo aqui a versão traduzida por Inês Barbosa como "Posfácio a Flaubert (A tentação de Santo Antão)" a partir do cotejamento das versões do texto de 1964 e de 1970. Em francês, tive contato com a versão do texto intitulada "La bibliothèque fantastique", publicada em DEBRAY-GENETTE, R. et al., 1983 [1967], p. 103-122.
} 
sempre ligada aos diversos tipos de repetição. Primeiramente, a repetição como retorno à mesma escrita, pois Flaubert escreve e reescreve $A$ tentação três vezes, além de trabalhar várias versões de seus rascunhos. Essa atitude obsessiva em busca do estilo perfeito é o sacrifício que Flaubert está condenado a viver, uma maneira especial de viver, como afirma ao longo de suas correspondências ${ }^{75}$.

Corrigir, retocar, retomar o que já foi escrito caracteriza o que Barthes (1972, p. 142) define como "a odisseia da escritura flaubertiana"76. O crítico mostra que esse trabalho de Flaubert é estruturado em dois eixos que mimetizam os da linguagem: no paradigmático são inseridas as rasuras, no sintagmático, as reformulações.

São muitos os adjetivos e as metáforas que o próprio Flaubert utiliza para caracterizar sua escritura, mas as que me chamam a atenção são a da viagem que lhe causa mal-estar ${ }^{77}$, retomando a imagem da odisseia, e a do mecanismo estranho e da atrocidade da frase, ligada ao incômodo de encontrar um lugar na “estante” da página:

Escrevi três páginas ao longo de toda semana, e ainda não estou contente com elas. O que é atroz é a dificuldade de encadear as ideias e fazer com que elas derivem naturalmente uma das outras ${ }^{78}$.

A frase flaubertiana pode ser entendida como corpo, uma vez que é o elemento principal de sua obra e alcança um status novo na Literatura não só pelo que o escritor afirma em relação à angústia do trabalho com a frase, como pelo fato de ser identificada também como objeto:

A odisseia da frase é o romance dos romances de Flaubert. A frase se torna, assim, em nossa literatura, um objeto novo: não apenas por direito, devido às inúmeras declarações de Flaubert sobre este assunto, mas também de fato: uma frase de Flaubert é imediatamente identificável, não apenas por seu

\footnotetext{
75 “Vous me demandez si mon roman sera bientôt fini? Hélas! non; j’en suis au tiers. Un livre a toujours été pour moi une manière spéciale de vivre, un moyen de me mettre dans un certain milieu. J'écris comme on joue du violon, sans autre but que de me divertir, et il m'arrive de faire des morceaux qui ne doivent servir à rien dans l'ensemble de l'oeuvre, et que je supprime ensuite.” Flaubert à Madame Jules Sandeau. Croisset, dimanche 7 août 1859.

76 “Pour Flaubert, la phrase est à la fois une unité de style, une unité de travail et une unité de vie, elle attire l'essentiel de ses confidences sur son travail d'écrivain.”

77 “Je suis plein de doutes, de rêves et de peurs. Une oeuvre, quelle qu'elle soit, est pour moi un long voyage; j’hésite à m’embarquer, et j'en ai d'avance mal au coeur.” Flaubert à Mademoiselle Amélie Bosquet. Croisset, juin 1862.

78 “J’ai écrit de toute ma semaine trois pages, et encore dont je ne suis pas enchanté. Ce qui est atroce de difficulté c'est l'enchaînement des idées et qu'elles dérivent bien naturellement les unes des autres.”. Flaubert à Louise Colet. En partie inédite en 1927. Croisset, 26 juin 1852. Neste momento, Flaubert está escrevendo Madame Bovary.
} 
"ar”, sua “cor” ou alguma construção habitual do escritor - o que poderia se dizer de qualquer autor - mas porque ela se apresenta sempre como um objeto separado, acabado, pode-se dizer quase transportável, por mais que ela não chegue ao modelo aforístico, pois sua unidade não está ligada à clausura de seu conteúdo, mas ao projeto evidente que a fundou como objeto: a frase de Flaubert é uma coisa. ${ }^{79}$

Essa frase que não termina e que se repete, como as voltas de uma espiral, já foi lida de diversas formas pela crítica: artesanal, por Barthes, explosiva, por Richard, e trágica, por Blanchot. Em Fogos de Artifício, livro-tese de Verónica Galíndez-Jorge (2009), lê-se que a frase flaubertiana direciona o olhar para o projeto de uma escritura inacabável e, nessa perspectiva, tem-se uma concepção semelhante à ideia de objeto, unidade sem clausura, apresentada na citação anterior de Barthes.

Nesse sentido, o segundo tipo de repetição flaubertiana discutido por Foucault é a repetição como recitação, que ecoa em todo projeto literário flaubertiano, já que, para ele “ $L a$ Tentation percorre toda a obra de Flaubert”, é “o sonho de sua escrita [de Flaubert]” e “existiu antes de todas as obras de Flaubert” (FOUCAULT, 2006, p. 76). Sobre esse tipo de repetição, que é próprio da citação, Compagnon aponta a união do ato de leitura (formado pela solicitação e excitação) ao ato de escrita (que é sempre reescrita) e utiliza a noção de escriptível (do Barthes de $S / Z$ ) para entender a escolha da rescritura, o que há no texto que nos leva (ou leva um escritor) a prolongar esse texto, recitando-o em nossos próprios textos:

Há sempre um livro com o qual desejo que minha escrita mantenha uma relação privilegiada, "relação" em seu duplo sentido, o da narrativa (da recitação) e o da ligação (da afinidade eletiva). Isso não quer dizer que eu teria gostado de escrever esse livro, que o invejo, que o recopiaria de bom grado ou o retomaria por minha conta, como modelo, que o imitaria, que o atualizaria ou citaria por extenso se pudesse; isso também não demonstraria o meu amor por esse livro. Não, o texto que é para mim 'escriptível' é aquele cuja postura de enunciação me convém (o que cita como eu). É por isso que esse texto não é nunca o mesmo livro, é por isso que o Quijote, de Menard, é também um outro Quixote ${ }^{80}$. (COMPAGNON, 2007, p. 43)

\footnotetext{
79 “[...] l’odyssée de la phrase est le roman des romans de Flaubert. La phrase devient ainsi, dans notre littérature, un objet nouveau: non seulement en droit, par les nombreuses déclarations de Flaubert à ce sujet, mais aussi en fait: une phrase de Flaubert est immédiatement identifiable, non point par son 'air', sa 'couleur' ou tel tour habituel à l'écrivain - ce que l'on pourrait dire de n'importe quel auteur - mais parce qu'elle se donne toujours comme un objet séparé, fini, l’on pourrait presque dire transportable, bien qu'elle ne rejoigne jamais le modèle aphoristique, car son unité ne tient pas à la clôture de son contenu, mais au projet évident qui l'a fondée comme un objet: la phrase de Flaubert est une chose”. (BARTHES, 1972, p. 142)

${ }^{80}$ Sobre isso, confira também a reflexão de Umberto Eco, no ensaio "Borges e a minha angústia da influência”, sobre a presença de Jorge Luis Borges em seus escritos: "Nestes dias, fui levado antes a refletir sobre o quanto me influenciou o 'modelo Menard'. É uma história que nunca deixei de citar, desde quando a li pela primeira vez. Em que sentido determinou o meu modo de escrever?” (ECO, 2003, p. 120)
} 
Como entender a escolha de uma postura de enunciação que está, não em um livro, mas em todo o projeto literário de Flaubert? Flaubert seria o Menard de uma biblioteca inteira? A resposta de Foucault talvez fosse afirmativa, pois a postura enunciativa de Flaubert ao trabalhar o caráter fantástico de $A$ Tentação não é buscar esse elemento em seus sentimentos ou em fenômenos naturais, mas na "exatidão do saber: sua riqueza está à espera no documento. Para sonhar, não é preciso fechar os olhos, é preciso ler” (FOUCAULT, 2006, p. 80). Assim, Foucault propõe o fenômeno de biblioteca como mais um tipo de repetição, desta vez, a repetição de uma rede de discursos, detalhes, elementos e repetições de repetições que formam um imaginário flaubertiano:

Nada mais há, além do rumor assíduo da repetição, que possa nos transmitir o que só ocorre uma vez. O imaginário não se constitui contra o real para negá-lo ou compensá-lo; ele se estende entre os signos, de livro a livro, no interstício das repetições e dos comentários: ele nasce e se firma no entremeio dos textos. É um fenômeno de biblioteca. (FOUCAULT, 2006, p. 80)

Essa postura enunciativa do escritor constituída por essa relação fundamental com os livros demanda também um tipo de leitura nesse sentido, deixando de lado a relação dual para tentar uma leitura imbricada nessa rede de livros, recobrindo-os, escondendo-os, manifestando-os, fazendo-os cintilar e desaparecer ${ }^{81}$ ao longo do percurso. É desta forma que Verónica Galíndez-Jorge (2009, p. 49) também percebe essa dimensão da repetição flaubertiana:

\begin{abstract}
A repetição começa, então, a adquirir outros contornos. Além de exigir uma leitura que não se basta na própria obra, obrigando o leitor a estabelecer uma rede de conexões, antecipando as correspondências baudelairianas, cria uma dimensão circular, se não espiral.
\end{abstract}

Além disso, afirma a pesquisadora, o trabalho de Flaubert nessa rede de relações com outros livros “convida o leitor à escuta atenta do murmúrio da literatura evocada” (GALÍNDEZ-JORGE, 2009, p. 49), sem com isso, é claro, defender uma leitura da obra pautada exclusivamente nas leituras e referências de Flaubert. Dizer que a leitura não se basta na própria obra significa admitir que ela mobiliza também a biblioteca do escritor e sua rede de relações literárias (por exemplo, ideias, projetos e livros citados e sugeridos na

\footnotetext{
81 "La tentation está seriamente concernida ao imenso domínio do impresso: ela tem lugar na instituição reconhecida da escrita; é menos um livro novo, a ser colocado ao lado dos outros, do que uma obra que se desenvolve no espaço dos livros existentes. Ela os recobre, os esconde, os manifesta, com um só movimento os faz cintilar e desaparecer." (FOUCAULT, 2006, p. 80-1. grifos meus).
} 
correspondência com outros escritores), para compreender o que Flaubert está ficcionalizando e criticando nessa repetição. Essa rede de conexões presente na obra flaubertiana requisita também a biblioteca do leitor, o qual pôde ter acesso a outros tantos livros que ficcionalizam esse espaço de relação entre os livros que é a biblioteca. Com base nisso, entendo que, apesar de esse fenômeno de biblioteca não estar presente apenas nos procedimentos de leitura e escrita de Flaubert, ele permite entrever um modo de ler livros em rede, uma metáfora interessante para ler esses livros que ficcionalizam esse espaço e essa multiplicidade de saberes e de discursos por meio da estrutura narrativa, de imagens, de citações e de transformações que perpetuam o prazer, o jogo, o vício, o perigo e outras tantas metáfora da leitura.

Talvez o procedimento de escrita mais colado a essas metáforas da leitura seja a cópia. Ela é o último tipo de repetição mencionado por Foucault (2006, p. 96), a partir do exemplo dos copistas Bouvard e Pécuchet:

Copiar o quê? Livros, seus livros, todos os livros, e este livro, sem dúvida, que é Bouvard et Pécuchet: pois copiar é nada fazer: é ser os livros que são copiados, ser esta ínfima distensão da linguagem que se reduplica, ser a dobra do discurso sobre si mesmo, ser esta existência invisível que transforma a palavra passageira no infinito rumor.

Adotar a cópia na escrita não reflete, necessariamente, uma paixão pelos livros copiados, mas antes um questionamento do estatuto da ficção e um modo de colocar em evidência as complicações enunciativas produzidas por essa prática. Diferentemente de Perec, que produzirá certas experimentações literárias a partir da cópia, como procurei mostrar anteriormente, Flaubert legará o experimento a seus personagens, os quais fracassarão por tentar reproduzir literalmente as técnicas e teorias presentes nos livros de botânica, química, história, entre outros, mostrando, ao mesmo tempo e em contrapartida, o sucesso com que os discursos se perpetuam, com que o conhecimento é “construído”.

A prática da cópia em Flaubert é sempre ambígua, pois procura colocar em evidência o que é contraditório ou o que é da ordem da tautologia, como comprovam os trechos do Sottisier $^{82}$ e diversos verbetes do Dictionnaire des idées reçues ${ }^{83}$. A cópia evidencia a relação

\footnotetext{
${ }^{82}$ Por exemplo: (a) "O tráfico de escravos não é contrário nem à humanidade, nem à religião, nem à justiça natural.” Mgr Bouvier, bispo do Mans, Institutions théologique, t. VI, ch. II, art. I, § 3. (b) "Um dos mais magníficos resultados do cristianismo é de ter abolido a escravidão.” Baguenault de Puchesse, Le Catholicisme présenté dans l'ensemble de ses preuves, p. 210. Ambos os trechos são do Sottisier, in. FLAUBERT, 2009, p. 468-9.
} 
interdiscursiva presente na biblioteca fantástica que Foucault lê em Flaubert, relação caracterizada pela falta de hierarquia entre os discursos, pela mobilidade desses discursos, pelo questionamento da Verdade única, da Inspiração para preencher a mítica página em branco. Ela é, portanto, uma moeda que traz, numa face, a escrita, na outra, a leitura. É isso que Borges ficcionaliza em seu personagem Pierre Menard, que queria escrever o Quixote e, para isso, cria um livro verbalmente igual ao de Cervantes, mas cujo sentido torna-se completamente diferente ${ }^{84}$.

Outro aspecto da cópia no projeto de Bouvard e Pécuchet e também no de Flaubert é seu inacabamento de princípio. Não há como parar de copiar porque não há como dar conta de todos os livros que existem: “A Biblioteca existe ab aeterno.”. É essa característica de BP que também abre espaço para a metáfora da biblioteca como modo de ler em relação, pois a obra inacabada provoca o leitor a prolongá-la de forma a prolongar em si o ritmo do pensamento do outro ${ }^{85}$, ou seja, não apenas por meio de uma leitura descritiva, expositiva e munida de determinado aparato teórico, mas procurando exercitar sua própria imaginação:

A obra inacabada é para nós a necessidade de uma invenção, e vemos bem a seu propósito que o crítico mais exato, mais respeitoso, é aquele cuja invenção consegue prolongar a do autor, a fazer com que esta entre a tal ponto nele mesmo que ele saberá fazer de sua imaginação uma parte da sua própria. (BUTOR, 1974, p. 199)

Leyla Perrone-Moisés tratou dos limites entre a crítica e a escritura ficcional e, a partir das obras dos escritores Barthes, Butor e Blanchot, analisou em que medida esses limites se entrecruzam. Ela afirma que a diferença entre o crítico e o escritor é que o primeiro "usufrui da propriedade alheia” e deve respeitar a propriedade do outro, já o escritor desfruta dos bens dos outros como se fossem seus, sem prestar contas ao outro. E conclui, “a relação entre “criadores” é uma relação de igualdade, a relação entre “criador” e crítico é uma relação de submissão” (PERRONE-MOISÉS, 1978, p. 65). Talvez a insistência nessa submissão do crítico leve-o a se armar de um aparato teórico para ler um livro, quando, na verdade, o que

\footnotetext{
${ }^{83}$ Por exemplo: ESTÔMAGO. Todos os males vêm de -. DICIONÁRIO: Rir disso - é feito apenas para ignorantes. CABELO: Cabeleira. Todos esses verbetes são do Dictionnaire des idées reçues. (FLAUBERT, 2009, p. 513, 506 e 499, respectivamente)

84 "Menard (talvez sem querê-lo) enriqueceu, mediante uma técnica nova, a arte fixa e rudimentar da leitura: a técnica do anacronismo deliberado e das atribuições errôneas. Essa técnica de aplicação infinita nos leva a percorrer a Odisséia como se fosse posterior à Eneida e o livro Le jardin de Centaure, de Madame Henri Bachelier, como se fosse de Madame Henri Bachelier. Essa técnica povoa de aventura os livros mais pacíficos.” (BORGES, 2001, p. 63)

${ }^{85}$ Como Georges Poulet (1971) define o pensamento crítico.
} 
fazemos é prolongar a sedução de leitura, assim como os próprios escritores aqui tratados propõem em suas obras.

As práticas de escrita de Perec (em $L V M E$ ) demonstram, inclusive, que ele também se dedicou a ler e escrever livros que "nunca terminaram de dizer aquilo que tinham para dizer”, ${ }^{\nexists 6}$ e que procurou criar contraintes como "molde” de produção ficcional para produzir esse mesmo efeito de inacabamento. Ao lado dele, Flaubert, um dos clássicos relidos por Perec, também praticou leituras de diversos clássicos, não só da literatura no sentido restrito dessa disciplina a que dedico meus estudos ou a escritores do mundo das Letras, mas da literatura no sentido geral de bibliografia, uma vez que percorreu ciências naturais, matemática, química, física, história, política, educação, amor, etc., para compor sua enciclopédia crítica em farsa. Nesse sentido, ambos se relacionaram com diversos discursos (literários ou não) para ficcionalizá-los em seus livros-bibliotecas, os quais, por sua vez, produzem um conhecimento próprio da literatura e da metáfora da biblioteca, o conhecimento promovido pelos “movimentos de leitura e releitura de suas obras”" ${ }^{\text {" }}$. É o que propõe João Alexandre Barbosa (1996), em seu ensaio “A Literatura como conhecimento”, quando sugere um modo de ler os intervalos das obras. Tomando como exemplo Dom Casmurro, de Machado de Assis, demonstra como esse romance requer atenção a detalhes que só significam no momento da releitura, da retomada de indícios no início do romance. No entanto, considero que essa leitura do intervalo é possível dentro e fora das obras, como no caso desses livros-bibliotecas de Flaubert e Georges Perec, que serão relidos no próximo capítulo.

Um exemplo de alguém que lê esses intervalos entre diversas obras é justamente Ítalo Calvino, em suas Seis propostas para o próximo milênio. Na conferência “Multiplicidade”, que foi citada anteriormente, Calvino começa a conferência com uma citação de Carlo Emilio Gadda (autor de Quer pasticciaccio brutto de via Merulana) para iniciar sua reflexão sobre o romance contemporâneo como enciclopédia, pois, para ele, esse autor "vê o mundo como um 'sistema de sistemas', em que cada sistema particular condiciona os demais e é condicionado por eles.” (CALVINO, 1990, p. 121). Em seguida, o escritor-crítico percorre trechos de Robert Musil, Proust, Goethe (cujas citações encontrou num livro de Hans Blumemberg, de 1984), Raymond Queneau, Flaubert, Thomas Mann, Perec, ou seja, coloca sua biblioteca em movimento, sem, no entanto, ser anacrônico ou artificial. Para falar da multiplicidade na

\footnotetext{
86 “Um clássico é um livro que nunca terminou de dizer aquilo que tinha para dizer.” (CALVINO, 2007, p. 11)

87 "O que significa afirmar que a validade do conhecimento veiculado pelo poético está antes no modo pelo qual se pôde articular os possíveis elementos de representação que na pura e simples presença ou ausência desses mesmos elementos." (BARBOSA, 1996, p. 80-1)
} 
literatura contemporânea, ele mesmo multiplica seu texto em diversas referências que traçam um panorama crítico sobre o tema. Dessa forma, ele alia o tema da multiplicidade à sua própria erudição literária e à ficcionalização da erudição e do modo de construção do conhecimento em rede que os escritores colocarão em questão, sobretudo no século XX. É com esta reflexão em mente que iniciarei a releitura de LVME e BP no Capítulo 2:

O ceticismo de Flaubert, justamente com sua curiosidade infinita pelo saber humano acumulado ao longo dos séculos, são os valores que tomarão como seus os maiores escritores do século XX; mas em relação a eles falarei de um ceticismo ativo, do senso do jogo e da aposta na obstinação de esclarecer relações entre discursos, métodos e níveis. O conhecimento como multiplicidade é um fio que ata as obras maiores, tanto do que se vem chamando de modernismo quanto do que se vem chamando de pósmodernismo, um fio que - para além de todos os rótulos - gostaria de ver desenrolando-se ao longo do próximo milênio. (CALVINO, 1990, p. 130) 


\section{Capítulo 2 - Os livros-bibliotecas de Flaubert e Perec: bibliotecas, livros e leitores ficcionalizados em Bouvard et Pécuchet e La Vie mode d'emploi}

\section{Era uma vez uma biblioteca que cabia num livro...}

Eu provei esse sentimento, novamente muito borgesiano, de me encontrar em uma biblioteca onde todas as estantes teriam sido derrubadas pelo chão, e dessa imensa desordem nasciam aproximações, acoplamentos surpreendentes mas, como dizem, "fecundos", e em todo caso bastante divertidos ${ }^{88}$.

Gérard Genette

Em A biblioteca à noite, Alberto Manguel dedica um capítulo à imaginação ${ }^{89}$, em que narra como essa faculdade própria à criação artística é, ao mesmo tempo, ponto de partida e de chegada de nossa relação com a biblioteca real (física). Ponto de partida, pois ele mesmo inicia o capítulo com um relato sobre a luz dentro de sua biblioteca pessoal, que conduz ao silêncio diante dos livros, à leitura das invenções dos outros, e à escuridão do lado de fora, que permite a conversa desinteressada e a criação das próprias invenções. Ponto de chegada, pois a imaginação permite criar diversas tramas e bibliotecas que não existem no mundo real.

A biblioteca é ficcionalizada por muitos escritores, que refletem sobre o imaginário desse espaço de relação entre tempos e saberes. Para Manguel (2006, p. 228), a primeira "biblioteca imaginária” da história da literatura talvez tenha sido inventada por Rabelais ${ }^{90}$, entre os séculos XV e XVI, com as histórias de Pantagruel e Gargantua, narrativas que zombam do mundo escolástico e monástico e apresentam uma série de livros imaginários, como exemplo, poderia citar um dos capítulos de Pantagruel, o episódio em que o personagem visita a abadia de Saint Victor. É preciso lembrar que é no mesmo Pantagruel que aparece pela primeira vez o termo encyclopédie ${ }^{91}$ em língua francesa, forma que será, mais tarde no século XIX, satirizada no inacabado romance flaubertiano Bouvard et Pécuchet.

\footnotetext{
88 “J'ai éprouvé ce sentiment, de nouveau très borgesien, de me trouver dans une bibliothèque où tous les rayons auraient été renversés par terre, et de cet immense désordre naissaient des raprochements, des accouplements surprenants mais, comme on dit, 'féconds', et en tout cas assez amusants.”

${ }^{89}$ Cf. MANGUEL, 2006, p. 221-239.

90 “Sua biblioteca imaginária é fruto de uma mente ativa demais para se deter e registrar seus pensamentos, e sua epopéia é uma miscelânea de episódios que permitem ao leitor escolher entre quase todas as seqüências, sentidos, tons e mesmo argumentos possíveis. [...] Rabelais, como seus colegas humanistas, questionava a noção de que autoridade equivalia à inteligência. 'Conhecimento sem consciência', diz Gargântua ao filho, 'é a ruína da alma’.” (Ibidem, p. 228)

91 “En quoy je vous puisse asseurer qu’il m’a ouvert le vrays pays et abisme de encyclopédie”, declara Panurge sobre a competência de Pantagruel.” (RABELAIS, 1964, p. 283 e 285)
} 
Além dessa mistura de gêneros, romance e enciclopédia, que retomaremos adiante, devemos ter em mente que Flaubert se insere numa tradição de escritores que ficcionalizam tanto o livro como objeto quanto o ato de leitura. De acordo com Franc Schuerewegen (1994), resenhando o livro Double Miroir - le livre dans le livre, de Joëlle Gleize (1992), Flaubert é frequentemente inserido em um percurso que aponta em direção à modernidade na história literária francesa, a saber: “a inocência de Stendhal, ainda muito próxima do otimismo das Luzes, a transição balzaquiana, a ruptura em Flaubert e o coroamento proustiano"92. Isso porque, de acordo com Gleize, Stendhal apresenta o livro como imagem da conquista da liberdade de leitura; Balzac oferece uma gama de diferentes tipos e qualidades de livros em sua ficção, incluindo também questões relativas ao mercado livreiro no contexto do século XIX; Flaubert inicia a "era da suspeita: 'suspeita sobre a leitura e seus efeitos, e também sobre sua representação romanesca”,"93; finalmente, Proust coroaria o tema da leitura em sua Recherche..., deslocando a questão da ficcionalização dos livros para o ato de leitura sob o ponto de vista do escritor e narrador ${ }^{94}$.

O tema do livro e da leitura também povoará o imaginário de diversos escritores fora do contexto francês. É o caso do conhecido “criador de bibliotecas” Jorge Luis Borges que, no século XX, começou a criar diversos volumes imaginários a partir do momento em que soube da doença que afetaria sua visão anos mais tarde. Apesar da doença, nunca abandonou a biblioteca física (trabalhou na Biblioteca Nacional da República Argentina por dezoito anos) e suas bibliotecas imaginárias, que são citadas em diversos contos e ensaios (talvez o mais conhecido seja “A biblioteca de Babel”). Talvez por isso, Borges ${ }^{95}$ seja também uma leitura constante para Georges Perec, como o Cahier des Charges deixa entrever, e para mim, como apontam algumas citações e alusões a contos do escritor neste capítulo.

Neste capítulo, percorrerei alguns temas ligados à biblioteca imaginária presente em $B P$ e $L V M E$ : a estrutura episódica dos romances e a inclusão dos saberes e dos livros na

\footnotetext{
92 “[...] on est également frappé de constater que le parcours proposé ne dévie en rien de la manière dont on présente habituellement en histoire littéraire l'émergence de la modernité disons: innocence de Stendhal, encore très proche de l'optimisme des Lumières, transition balzacienne, coupure chez Flaubert et couronnement proustien.” (SCHUEREWEGEN, 1994, p.125)

93 “C'est le commencement de l'ère du soupçon: 'soupçon sur la lecture et ses effets, mais aussi sur sa représentation romanesque’.” (GLEIZE, J. apud SCHUEREWEGEN, 1994, p.125)

${ }^{94}$ Sobre isso, convido o leitor a visitar a tese de doutorado de Samira Murad (2012), que é especificamente "Sobre a leitura de À la recherche du temps perdu" e discute a questão da leitura além da figuração desse tema no texto por meio da análise do papel do leitor.

${ }^{95}$ Sobre essa relação entre Perec e Borges, convido o leitor a conhecer a tese de Jacques Fux (2010), que propõe um estudo comparativo da utilização da matemática em procedimentos de escrita de Perec e Borges, defendendo que este último é um plagiário por antecipação do Oulipo.
} 
ficção, que implicam em uma hibridização de gêneros textuais na composição do discurso ficcional, na presença de personagens leitores, autodidatas e pesquisadores e na reflexão sobre o estatuto romanesco e ficcional.

Diante de tais questões impostas por esses livros feitos de livros, seria possível dizer que há neles um encontro da erudição com a ficção ${ }^{96}$ ? Segundo Bénabou, no caso de Georges Perec, “o texto não é produtor de saber, mas produtor de ficção. É dizer que a tentação do didatismo, tão presente e pesada em tantos outros (tanto antigos e como modernos) é aqui claramente e deliberadamente descartada",97.

O próprio Flaubert, em 1853, afasta a possibilidade de explicar didaticamente os aspectos da ciência nos textos literários ${ }^{98}$. No entanto, pensando para além da representatividade dos diversos campos da ciência na literatura para afirmar ou não o aspecto didático da obra, acredito que é possível observar um certo “didatismo” próprio do texto literário de Flaubert e de Perec no sentido de apontarem para um modo de ler seus romances que não visa, por exemplo no caso flaubertiano, a busca pela erudição de um homem do oitocentos. Nessa perspectiva, João Alexandre Barbosa (1996, p. 84) defende a existência de um conhecimento próprio da literatura como característica inerente aos textos clássicos, os quais demandam sempre uma releitura não só do texto em si como do significado da literatura no contexto do leitor ${ }^{99}$. Por esse motivo, estes são textos que apontam em direção ao

\footnotetext{
${ }^{96}$ Sobre esse encontro, Bénabou afirma que a principal referência a se pensar é Rabelais, pois é "o modelo ao qual se ligam todos os que têm uma preocupação semelhante [a essa], e é nesse conjunto que figuram, não por acaso, alguns dos autores que mais influenciaram Perec: Flaubert, Verne, Roussel, Queneau.” BÉNABOU. Vrai et Fausse Érudition chez Perec. In: RIBIÈRE, 1990, p. 42 / No original: "Rabelais est en effet le modèle auquel se rattachent tous ceux qui ont eu une préoccupation analogue, et au nombre desquels figurent, pas par hasard, quelques-uns des auteurs qui ont le plus influencé Perec: Flaubert, Verne, Roussel, Queneau.”

97 “Eu diria antes que essa relação se inscreve no contexto do que seria necessário chamar de 'o sonho enciclopédico’ de Perec, o que conviria examinar mais a fundo a origem. Esse sonho que era a princípio o seu, ele não deixou de transmitir a seus heróis! Daí a abundância, em La Vie mode d'emploi, desses personagens eruditos, de pesquisadores, cuja vida é inteiramente ocupada pela perseguição de um saber, pela elucidação de um mistério. Smautf ou o doutor Dinteville são bons exemplos disso, mas é mesmo em um Léon Marcia que aparece em estado puro esse frenesi, essa bulimia de saber.” No original: “Je dirais plutôt que ce rapport s'inscrit dans le cadre de ce qu'il faudrait appeler 'le rêve encyclopédique' de Perec, et dont il conviendra d'examiner plus loin l'origine. Ce rêve qui était d'abord le sien, il n’a eu de cesse que de le transmettre à ses héros! D’où l'abondance, dans La vie mode d'emploi, de ces personnages d'érudits, de chercheurs, dont la vie est entièrement occupée par la poursuite d'un savoir, par l'élucidation d'un mystère. Smautf or le docteur Dinteville en sont de bons exemples, mais c'est bien entendu chez un Léon Marcia qu’apparaît à l'état pur cette frénésie, cette boulimie de savoir.” (BÉNABOU, 1990, p. 42)

98 “A literatura terá cada vez mais as características da ciência; ela será, sobretudo, expositiva, o que não quer dizer didática.” No original: "La littérature prendra de plus en plus les allures de la science; elle sera surtout exposante, ce qui ne veut pas dire didactique”. Flaubert à Louise Colet, 6 avril 1853, II, 298.

99 “Não é um conhecimento progressivo ou por acumulação: a sua possibilidade está na leitura (que sempre exige a releitura) de uma região de intervalo situada entre os conteúdos de representação e sua efetivação poética, vale dizer, sua instauração como 'linguagem dentro da linguagem'.” (BARBOSA, 1996, p. 84)
} 
didatismo, mas não do conteúdo, já que $B P$ não é de fato uma enciclopédia a ser consultada como fonte de pesquisa para conhecer técnicas de agronomia, por exemplo, nem LVME é um livro de autoajuda com instruções para a vida como poderia sugerir o título. Talvez justamente por serem clássicos, esses textos apresentam um certo percurso didático da leitura, que é percebido pela própria organização discursiva em episódios temáticos, no caso do romance de Flaubert, e pelos elementos paratextuais que compõem o romance de Perec, como os índices e bibliografias que serão apresentados adiante. Com isso, pretendo justificar o tema da biblioteca imaginária escolhido para relacionar os romances de Flaubert e Perec neste capítulo: além de ser um tema de destaque nas duas obras, seja por meio de imagens, citações e discursos dos narradores e dos personagens, a biblioteca imaginária retoma bastante o fenômeno de biblioteca tratado no Capítulo 1 desta dissertação, isto é, um fenômeno de leitura que exige uma releitura a fim de ressignificar o conhecimento que as duas obras agregam ao meu contexto atual como leitora:

Por isso, um crítico nosso contemporâneo, o inglês Frank Kermode, pôde chegar à conclusão de que "a sobrevivência do clássico deve depender de ele possuir um acréscimo (surplus) de significante”. E ele acrescenta: "as in King Lear or Wuthering Heights this may expose them to the charge of confusion, for they must always signify more than is needed by any one interpreter or any one generation of interpreters". Ora, é precisamente a possibilidade dessa 'charge of confusion' que responde pela perenidade da obra clássica, impondo-lhe releituras sucessivas, sempre incompletas. Releituras que, buscando absorver aquele surplus de significante referido por Kermode, terminam por ampliar o leque de significados que traduzem o conhecimento veiculado pela obra. (BARBOSA, 1996, p. 85)

\section{Bouvard e Pécuchet no jardim de saberes que se bifurcam}

As obras Pantagruel e Gargântua de François Rabelais chamam a atenção pelo modo como abrem caminho para uma infinidade de imitações, paródias e diálogos que ressoam até os dias atuais. Isso porque Rabelais “foi ressuscitado por sua liberdade de expressão, mas também de modo suspeito por sua potência, seu populismo e sua obscenidade, no século XIX”100. A frase "Conhecimento sem consciência é a ruína da alma”, que Gargântua diz ao seu filho é a mesma que o narrador flaubertiano, por exemplo, poderia dizer aos leitores de Bouvard et Pécuchet, e a frase adquiriria um novo significado. Esse romance inacabado de Gustave Flaubert trata da história de dois senhores que, sentados no mesmo banco, encontram-se por acaso, descobrem afinidades e decidem iniciar a empreitada de reunir todo o

\footnotetext{
100 "Il [Rabelais] est ressuscité pour sa liberté de parole, mais aussi de façon suspecte pour sa puissance, son populisme et son ‘obscenité' par le XIXe siècle.” FRAGONARD. Préface. In: RABELAIS, 1998, p. 23.
} 
conhecimento possível: da agricultura à política. Para isso, eles se mudam para o campo (em Chavignolles) quando Bouvard herda uma quantia inesperada de seu pai (que havia se passado por tio em vida), e a dupla começa a ler diversos manuais e fazer experimentos embasados em várias teorias e lugares-comuns que circulavam na época.

Enquanto os gigantes de Rabelais ilustram a dimensão exagerada do valor dado ao homem renascentista, os "velhos" de Flaubert podem tanto ilustrar como o homem daquele tempo está ultrapassado em relação à efervescência dos novos discursos científicos quanto revelar a tolice humana frente a um compêndio de teorias científicas que eram aceitas sem uma leitura crítica, transformadas quase em religião. O resultado de ambas as leituras, naturalmente, é o riso diante dos hábitos desses grandes personagens, por exemplo:

- A escatologia em Gargantua, no capítulo XII - Como Grandgousier reconheceu a maravilhosa inteligência de Gargantua na invenção do limpa-traseiro (torchecul):

[...] Mas, para concluir, afirmo e sustento que não existe melhor limpatraseiro que um gansinho bem cheio de penas, visto que podemos segurar a cabeça entre as pernas."

- A fé de Bouvard e Pécuchet diante das palavras do manual de educação física de Francisco Amorós y Ondeano, no capítulo VIII:

Pour suivre les prescriptions du manuel, ils tâchèrent de devenir ambidextres, jusqu'à se priver de la main droite, temporairement. Ils firent plus: Amoros indique les pièces de vers qu'il faut chanter dans les manoeuvres - et Bouvard et Pécuchet, en marchant, répétaient l'hymne $\mathrm{n}^{\circ} .9$, "Un roi, un roi juste est un bien sur la terre." Quand ils se battaient les pectoraux : "Amis, la couronne et la gloire”, etc. Au pas de course :

A nous l'animal timide!

Atteignons le cerf rapide!

Oui! nous vaincrons!

Courons! courons! courons!

Et plus haletant que des chiens, ils s'animaient au bruit de leurs voix. $(B P, \text { p. 275) })^{102}$

\footnotetext{
101 “Comment Grandgousier reconnut la merveilleuse intelligence de Gargantua à l'invention d’un torchecul. [...] Mais, pour conclure, j'affirme et soutiens qu'il existe pas de meilleur torchecul qu'un oison bien duveteux, pourvu qu’on lui tienne la tête entre les jambes.” (RABELAIS, 1998, p.129)

102 "Para seguir as prescrições do manual, eles decidiram se tornar ambidestros e até mesmo se privar do uso da mão direita, temporariamente. Eles fizeram mais: Amoros indica os trechos de versos que devem ser cantados durante os exercícios - e Bouvard e Pécuchet, caminhando, repetiam o hino no. 9, "Um rei, um rei justo é um rei sobre a terra.” Quando batiam no peitoral: ‘Amigos, a coroa e a glória.’, etc. Em passo de corrida: A nós o animal tímido!

Alcancemos o ágil cervo!

Sim! Nós venceremos!

Corramos! corramos! corramos!

E mais arquejantes que cachorros, eles se animavam com o barulho de suas vozes.”
} 
A estrutura utilizada por Flaubert para narrar essa história, que permaneceu inacabada por conta da morte do escritor em 1880, é episódica, com efeito enciclopédico, pois cada capítulo é dedicado a um ou mais domínios do conhecimento. Resumidamente: agricultura (capítulo II), química, anatomia, medicina, geologia e astronomia (capítulo III), arqueologia, história e filosofia da história (capítulo IV), literatura e gramática (capítulo V), política, filosofia e economia política (capítulo VI), amor (capítulo VII), ginástica, ocultismo e psicologia (capítulo VIII), religião (IX) e educação (capítulo X). Apesar de explorar essas ciências, o objetivo de Flaubert não é fazer um compêndio das ciências modernas,

mas explorar o imaginário das ciências: as representações, os lugarescomuns, inquietudes que provêm das ciências e constituem novas crenças para um público indiretamente informado e entretanto apaixonado pela ciência (a nova autoridade do século XIX) [.....$^{103}$

Para isso, Flaubert mescla o gênero romanesco com o enciclopédico, sem deixar de lado a ironia e o aspecto grotesco da sátira menipeia, gênero do qual faz parte a obra de Rabelais e que é caracterizado por narrativas centradas em algum tipo de aventura em busca de conhecimento ${ }^{104}$. Segundo Thorel-Cailleteau (2011), a estrutura episódica de Bouvard et Pécuchet é próxima de narrativas de busca como a Odisseia ou Candide, que também apresentam a digressão como elemento constante na história, sobretudo, nos diálogos. O trabalho com a digressão, presente nessas narrativas, compõe seu caráter enciclopédico e estabelece, na visão da mesma autora, um pacto de leitura hermenêutico, diferente do pacto ficcional característico dos romances comuns:

A desenvoltura narrativa de Flaubert, a sutil inverossimilhança que ele coloca e que se impõe como uma fonte de cômico, já na coreografia do encontro entre os dois homenzinhos, instauram então com o leitor, implicitamente, um pacto hermenêutico no lugar de um pacto ficcional comum aos romances ${ }^{105}$.

\footnotetext{
103 “L'objectif de Flaubert n'est pas de faire un tableau de sciences modernes et de s'en prendre à la science de son temps mais d'explorer l'imaginaire des savoirs: les répresentations, idées reçues, inquiétudes qui dérivent des sciences et constituent de nouvelles croyances pour un public indirectement informé et pourtant féru de science (la nouvelle autorité du XIXe) dont Homais était déjà, dans Madame Bovary, le représentant.” Cf. o artigo de Gisèle Séginger. "Forme Romanesque et savoir. Bouvard et Pécuchet et les sciences naturelles". In: Revue Flaubert, n. 4, 2004, Não paginado.

${ }^{104}$ Sobre essa definição de sátira menipeia e a relação com o gênero híbrido do romance-enciclopédia crítica em farsa Bouvard et Pécuchet, confira o artigo de Sylvie Thorel-Cailleteau. "Bouvard et Pécuchet: La question du genre”. In: Revue Flaubert, n. 11, 2011, Não paginado.

105 "La désinvolture narrative de Flaubert, la subtile invraisemblance qu'il met en place et qui s'impose comme une source de comique, dès la chorégraphie de la rencontre entre les deux bonshommes, instaurent ainsi avec le lecteur, implicitement, un pacte herméneutique au lieu du pacte fictionnel ordinaire aux romans”. (Ibidem. Não paginado.)
} 
No entanto, o pacto ficcional também foi previsto por Flaubert em $B P$, já que ele declara que incluirá personagens secundários na história, pois “é necessário algo que pareça ação, uma espécie de história contínua para que a coisa não tenha a cara de uma dissertação filosófica”" ${ }^{106}$. Mesmo não sendo uma dissertação filosófica, alguns críticos leram $B P$ nessa chave de uma “arqueologia das ideias modernas”107, já que não são os personagens que regem a narrativa, mas sim os saberes que Bouvard e Pécuchet buscam para alcançar seu maior desejo: a Ciência completa, total e verdadeira. É por isso também que esse romance não poderia ter outro fim senão permanecer inacabado, já que esse desejo nunca poderia ser satisfeito. Não se trata de uma estrutura própria do gênero romanesco com uma narrativa, uma intriga, um clímax e um final - uma estrutura em forma de pirâmide ${ }^{108}$, como aparece, por exemplo, em L'Éducation sentimentale ou em Madame Bovary. Há aqui uma forma mais próxima da espiral, pautada pelo reconhecimento da falta de um saber para alcançar a Ciência, a busca desse saber por meio de leituras e experiências e a falha dessa busca pelo reconhecimento da falta de outro saber. Refiro-me, aqui, ao saber e à ciência nos termos utilizados por Flaubert em um de seus rascunhos: “Toda a ciência contém [está contida] em um livro. Se eles conhecessem esse livro, eles saberiam essa ciência”109. Nesse sentido, os livros desempenham um papel fundamental na ficcionalização dos saberes em $B P$, pois "não se trata apenas de um livro feito de livros no sentido intertextual, mais de um livro-biblioteca que nomeia e mostra os livros, materialmente” ${ }^{\text {110 }}$. Não é à toa que Gisèle Séginger $(2004)^{111} \mathrm{e}$

\footnotetext{
106 "Et avec des personnages secondaires, car il faut un semblant d'action, une espèce d'histoire continue pour que la chose n'ait pas l'air d'une dissertation philosophique”. Flaubert à Madame Roger des Genettes. Paris, avril 1875.

107 "BP se veut une archéologie des idées modernes; les savoirs fournissent la matière narrative, mais ce sont les idées qui importent et les idées dépassent leur temps". Cf. o artigo de Yvan Leclerc. "Notes de cours sur Bouvard et Pécuchet, fictions du savoir et savoirs de la fiction”. In: Revue Flaubert, n. 11, 2011, Não paginado.

${ }^{108}$ Gisèle Séginger já observa em L'Éducation sentimentale o início da desconstrução dessa organização do romance em forma de pirâmide, mas concorda que é em $B P$ que Flaubert instaurará uma nova organização romanesca. Essa nova organização, segundo ela, está pautada no que Ricoeur teoriza em Temps et récit, a saber: " le rapport inextricable entre deux activités qu'il voudrait pourtant dissocier: raconter et démontrer [...] Flaubert met en abyme dans le roman une interrogation qui réoriente son propre travail. Comment concevoir une forme nouvelle de roman, une représentation indépendante de tout jugement lorsqu'on a reconnu que tout récit est déjà une forme de jugement?" Cf. o artigo "Forme romanesque et savoir. Bouvard et Pécuchet et les sciences naturelles”. In: Revue Flaubert, n. 4, 2004, Não paginado.

109 "Toute la science contient [est contenue] dans un livre. S'ils savaient ce livre, ils sauraient cette science” (f॰ 3219 apud LECLERC. op.cit. Não paginado.)

110 "Ce n'est pas seulement un livre fait de livres au sens intertextuel, mais un livre-bibliothèque qui nomme et montre les livres, matériellement.” (Ibidem. Não paginado.)

111 “L’imaginaire spatial l'emporte sur l'imaginaire temporel, et structure un nouveau type de roman dont les chapitres correspondent moins à de grands moments du récit qu'à des domaines de connaissance, à des divisions qui pourraient être celles d'une bibliothèque.” Cf. o artigo já citado de Séginger. In: Revue Flaubert, n. 4, 2004, Não paginado.
} 
Joëlle Gleize (1992) $)^{112}$, que estudaram a ficcionalização dos saberes e dos livros na obra de Flaubert, associam as divisões dos capítulos às divisões de categorias presentes em uma biblioteca, já que cada um dos capítulos mobilizará uma coleção de livros que é mencionada, citada e/ou aludida pelos personagens ou pelo próprio narrador em terceira pessoa. Vamos percorrer, a seguir, alguns trechos do capítulo II de $B P$, no qual os personagens exploram técnicas de jardinagem, agronomia e agricultura, e observar de que forma os saberes são ficcionalizados no romance.

Como uma semente, a ânsia de saber de Bouvard e Pécuchet nascerá no jardim:

Bouvard planta une pivoine au milieu du gazon - et des pommes d'amour qui devaient retomber comme des lustres, sous l'arceau de la tonnelle.

Pécuchet fit creuser devant la cuisine, un large trou, et le disposa en trois compartiments, où il fabriquerait des composts qui feraient pousser un tas de choses dont les détritus amèneraient d'autres récoltes, procurant d'autres engrais, tout cela indéfiniment; - et il rêvait au bord de la fosse, apercevant dans l'avenir, des montagnes de fruits, des débordements de fleurs, des avalanches de légumes. Mais le fumier de cheval si utile pour les couches lui manquait. Les cultivateurs n'en vendaient pas; les aubergistes en refusèrent. Enfin, après beaucoup de recherches, malgré les instances de Bouvard, et abjurant toute pudeur, il prit le parti 'd'aller lui-même au crottin'! ${ }^{113}$ (BP, p. 77)

Enquanto um deles planta uma flor, o outro fabrica adubo sonhando com as maravilhas que surgiriam dele: frutas, flores, legumes em abundância. O jardim será como uma promessa de apropriação de um fragmento da natureza assim como a chance de colocar em prática diversas técnicas de jardinagem disponíveis nos manuais por eles consultados. Esse espaço será tomado como uma verdadeira seara de saberes, na qual eles poderão utilizar os instrumentos de horticultura que compraram anteriormente: "balanças, uma fita métrica de

\footnotetext{
112 "[...] [a narrativa das leituras] da busca enciclopédica de Bouvard et de Pécuchet é baseada numa classificação temática de livros e saberes que se aproxima muito de um catálogo de biblioteca.”/ No original: “Alors que dans la 'première' Éducation sentimentale, le récit des lectures de Jules évite l'énumération des livres lus en ne racontant que la lecture et son progrès, celui de la quête encyclopédique de Bouvard et de Pécuchet se fonde sur un classement thématique des livres et des savoirs qui serre au plus près le catalogue de bibliothèque." (GLEIZE, 1992, p. 22)

113 "Bouvard plantou uma begônia, no centro do gramado, e tomates, que deveriam pender como lustres sob a abóboda do caramanchão.

Pécuchet mandou escavarem, diante da cozinha, um grande buraco dividido em três compartimentos, onde prepararia o adubo que faria brotar uma profusão de coisas, cujos detritos trariam outras plantas, fornecendo outros fertilizantes, tudo isso indefinidamente; e sonhava à beira da fossa, vislumbrando no futuro montanhas de frutos, inundações de flores, avalanches de legumes. Mas faltava-lhe estrumes de cavalo, tão útil para as semeaduras. Os cultivadores não o vendiam; os estalajadeiros recusavam-se a cedê-lo. Finalmente, depois de muito procurar, apesar das instâncias de Bouvard e abjurando qualquer pudor, decidiu 'ir ele próprio até os excrementos!”’
} 
agrimensor [...] inclusive um barômetro sistema Gay-Lussac” e um monte de “coisas que talvez pudessem ser úteis”:

Ils s'achetèrent des instruments horticoles, puis un tas de choses "qui pourraient peut-être servir” telles qu'une boîte à outils (il en faut toujours dans une maison), ensuite des balances, une chaîne d'arpenteur, une baignoire en cas qu'ils ne fussent malades, un thermomètre, et même un baromètre "système Gay-Lussac" pour des expériences de physique, si la fantaisie leur en prenait. ${ }^{114}$ (BP, p. 66, grifos meus).

Mesmo que sejam, na maioria, estranhos para dois senhores que viveram toda a vida na cidade, os instrumentos e técnicas agrícolas parecem ser familiares aos dois copistas. É cômica, por exemplo, a parte em que Pécuchet "sabe" que o estrume de cavalo é um bom adubo para semeaduras e decide ir em busca dos excrementos. Além disso, é interessante notar o uso das aspas, que apontam para o trabalho com o discurso indireto livre, como no exemplo da compra de “coisas que poderiam ser úteis”.

Os personagens são verdadeiros colecionadores de objetos enciclopédicos ${ }^{115}$, isto é, objetos destinados à obtenção de determinado saber, e a forma como buscam determinado saber - o da agricultura, por exemplo - parece transformar esse saber em mito. Neste ponto, não há como não subir à escrivaninha o Mythologies, de Barthes, em que Bouvard et Pécuchet aparece como um exemplo de mito artificial ${ }^{116}$. Segundo o crítico, o discurso dos copistas compõe uma palavra mítica, em que o sentido da língua só é suficiente para dar forma a um significado vazio representado pela insaciedade tecnológica dos personagens.

\footnotetext{
114 “Compraram instrumentos de horticultura, depois um monte de coisas 'que talvez pudessem ser úteis' tais como uma caixa de ferramentas (uma casa deve ter sempre uma), em seguida, balanças, uma fita métrica de agrimensor, uma banheira para prevenir que não ficassem doentes, um termômetro, e até mesmo um barômetro 'sistema Gay-Lussac' para experiências de física, se lhes desse na telha.”

${ }^{115}$ Em 1964, no artigo "Les planches de l’Encyclopédie”, Roland Barthes define objeto enciclopédico de uma forma mais ampla, como todo produto criado pelo homem: roupas, ferramentas, armas, móveis, isto é, tudo aquilo que é moldado pelo homem a partir de matérias-primas como madeira, metal e vidro. Enfim, tudo aquilo que pode ser catalogado: “Les objets présents sont à la lettre encyclopédiques, c'est-à-dire qu'ils couvrent toute la sphère des matières mises en forme par l'homme: vêtements, voitures, ustensiles, armes, instruments, meubles, tout ce que l'homme découpe dans le bois, le metal, le verre ou la fibre est ici catalogue, du ciseau à la statue, de la fleur artificielle au navire.” (BARTHES, 1972, p. 90)

116 "É o que se poderia chamar de mito experimental, um mito em segundo grau. Bouvard et Pécuchet representam uma certa burguesa (aliás em conflito com outras camadas burguesas) : seu discurso constitui já uma palavra mítica: a língua tem mesmo um sentido, mas esse sentido é a forma vazia de um significado conceitual, que é aqui uma espécie de insaciedade tecnológica: o encontro do sentido e do conceito forma, nesse primeiro sistema mítico, uma significação que é a retórica de Bouvard et Pécuchet."/ No original: "C’est ce que l'on pourrait appeler un mythe expérimental, un mythe au second degré. Bouvard et Pécuchet représentent une certaine bourgeoisie (en conflit d'ailleurs avec d'autres couches bourgeoises): leurs discours constituent déjà une parole mythique: la langue y a bien un sens, mais ce sens est la forme vide d'un signifié conceptuel, qui est ici une sorte d'insatiété technologique: la rencontre du sens et du concept forme, dans ce premier système mythique, une signification qui est la rhétorique de Bouvard et Pécuchet.” (BARTHES, 1957. p. 244)
} 
A partir das técnicas adquiridas na jardinagem, eles ambicionam ter sucesso no ramo da agricultura e fazem uma pesquisa de campo na fazenda de M. le Comte. Após ficarem deslumbrados com tudo que haviam visto, eles decidem ter uma fazenda semelhante. É neste ponto que surge a necessidade da biblioteca:

Tout ce qu'ils avaient vu les enchantait. Leur décision fut prise. Dès le soir, ils tirèrent de leur bibliothèque les quatre volumes de la Maison rustique, se firent expédier le cours de Gasparin, et s'abonnèrent à un journal d'agriculture. $^{117}$ (BP, p. 82)

Com a "bibliografia” em mãos, eles se metamorfoseiam em verdadeiros fazendeiros : compram uma carroça, um grande chapéu, botas até os joelhos, um bastão... E saem à procura de informações dos trabalhadores das outras fazendas e de mestre Gouy.

Os dois copistas movimentam a própria biblioteca e as bibliotecas alheias. Outros personagens são consultados, Bouvard e Pécuchet discutem e colocam em prática teorias contrárias, enfim, os copistas repetirão os seguintes procedimentos ao longo dos capítulos: a coleção e a desconstrução de saberes. A organização desses mitos flaubertianos visa à própria desconstrução, isto é, à destituição de autoridade dos saberes, já que os personagens fracassam e empreendem uma nova busca para alcançar alguma sensação de totalidade. Tratase, portanto, de uma crítica aos métodos científicos. Não é à toa que o emprego de alguns métodos produz verdadeiros monstros, como as couves plantadas no jardim, que ficam enormes e intragáveis ("Que importância isso tinha? Pécuchet ficou satisfeito por possuir um monstro”); ou os melões, cujo cultivo Pécuchet considerava o “apogeu da arte”, que se tornam frutas híbridas com gosto de abóbora:

En effet, comme il avait cultivé les unes près des autres des espèces différentes, les sucrins s'étaient confondus avec les maraîches, le gros Portugal avec le grand Mogol - et le voisinage des pommes d'amour complétant l'anarchie, il en était résulté d'abominables mulets qui avaient le goût de citrouilles. ${ }^{118}(B P$, p. 87$)$

Conhecer e semear diferentes espécies de melão não basta para produzir de fato este fruto. Ao tentar domesticá-la, a natureza transgride o conhecimento dos personagens e cria

\footnotetext{
117 "Tudo o que haviam visto os encantava. Tomaram uma decisão. Logo à noite, eles tiraram de sua biblioteca os quatro volumes da Maison rustique, fizeram mandar o curso de Gasparin e assinaram uma revista de agricultura."

118 "De fato, como ele havia cultivado espécies diferentes umas perto de outras, os melões adocicados confundiram-se com os hortenses, o Grão Portugal com o grande Mogol - e a proximidade dos tomates, completando a anarquia, resultaram em híbridos abomináveis que tinham gosto de abóboras.”
} 
monstros inclassificáveis. Para Barthes (1972), a monstruosidade é poética ${ }^{119}$, pois trata-se de uma categoria que escapa à ordem e à homogeneidade dada aos objetos na enciclopédia. $\mathrm{O}$ que escapa à classificação angustia, mas permite uma mudança de percepção, isto é, o que é estranho impulsiona novas pesquisas e experiências. A anarquia do cultivo e a falta de análise do local do plantio também levarão ao fracasso do cultivo das flores e, mais uma vez, a biblioteca não trará solução:

Bouvard, comme lui, rencontrait des obstacles. Ils se consultaient mutuellement, ouvraient un livre, passaient à un autre, puis ne savaient que résoudre devant la divergence des opinions.

Ainsi, pour la marne, Puvis la recommande; le manuel Roret la combat. Quant au plâtre, malgré l'exemple de Franklin, Rieffel et M. Rigaud n'en paraissent pas enthousiasmés.

Les jachères, selon Bouvard, étaient un préjugé gothique. Cependant, Leclerc note les cas où elles sont presque indispensables. Gasparin cite un Lyonnais qui pendant un demi-siècle a cultivé des céréales sur le même champ; cela renverse la théorie des assolements. Tull exalte les labours au préjudice des engrais; et voilà le major Beatson qui supprime les engrais, avec les labours! ${ }^{120}(B P$, p. 87)

Para intensificar a produção, a marga é recomendada por um teórico, enquanto outro o condena. Os manuais se contradizem ao sugerir o uso do gesso, dos alqueives, das lavras e dos adubos. Esse trecho exemplifica uma característica constante na construção discursiva de $B P$ : os personagens consultam diversos livros e não conseguem encontrar uma síntese, produzindo uma soma das opiniões dos teóricos. Nesses momentos de discussão dos saberes, há uma mudança no discurso promovida pela mudança do tempo verbal do passado (simples ou imperfeito - tempo da narrativa) para o presente, que talvez pudesse ser chamado de tempo da “exposição”, já que é o momento em que a materialidade do livro assim como seu conteúdo se apresentam como perenes. A narrativa é colocada em segundo plano para dar lugar à exposição dos saberes estudados, os quais não colaborarão para o sucesso da empreitada do encontro da Ciência total. Além disso, é interessante notar a falta do recurso de

\footnotetext{
119 “[...] toutes ces transgressions de la nature font comprendre que le poétique (car le monstrueux ne saurait être que le poétique) n'est jamais fondé que par un déplacement du niveau de perception: c'est l'une des grandes richesses de encyclo-pédie que de varier (au sens musical du terme) le niveau auquel un même objet peut être perçu, libérant ainsi les secrets mêmes de la forme [...]”. (BARTHES, 1972, p. 102)

120 "Bouvard, assim como ele [Pécuchet], encontrava obstáculos. Eles se consultavam mutuamente, abriam um livro, passavam a um outro, depois não sabiam o que resolver diante da divergência de opiniões.

Assim, a marna (mistura natual de argila e calcário), Puvis recomenda; já o manual Roret a combate. Quanto ao gesso, apesar do exemplo de Franklin, Rieffel e M. Rigaud não pareciam entusiasmados com isso.

Os alqueives, segundo Bouvard, eram um preconceito gótico. Entretanto, Leclerc nota o caso em que eles são quase indispensáveis. Gasparin cita o caso de um lionês que durante meio século cultivou cereais no mesmo campo; isso derruba a teoria da rotação de culturas. Tull exalta as lavras em detrimento dos adubos; e eis o major Beatson, que suprime os adubos e as lavras!”
} 
aspas e itálicos que poderiam indicar o discurso alheio, a citação dos livros. O "fichamento" de ideias é feito pelo discurso indireto livre de quem exatamente: personagens ou narrador? Quanto tempo eles demoram para ler todos esses teóricos? A falta desses indícios, comuns no romance tradicional do século XIX, revelam a lógica paradigmática desse romance paradoxal que, segundo Gisèle Séginger (2000 e 2004) ${ }^{121}$, privilegia a enumeração de experiências e pesquisas semelhantes. No entanto, trata-se de enumerações de discursos que, na verdade, não possuem caráter informativo, mas um efeito estético de caráter ficcional - é uma das formas pelas quais os saberes compõem a ficção de $B P$.

Diante de tantas teorias de fertilização, Bouvard é tomado pelo “delírio do adubo" e investe trinta mil francos em estrume: acumula galhos, penas, sangue, tripas, urina, cadáveres e instala uma ferramenta na carroça para bombear seu "adubo" sobre as colheitas. O fracasso não tarda a aparecer, não só com a queda na venda dos produtos, como no verdadeiro prejuízo causado pelo grande incêndio que acontece na fazenda.

Da agricultura passam à destilação. E como essa biblioteca de saberes é um lugar de transformação e revelação, os personagens se dedicam intensamente a essa nova atividade e sonham com um novo produto, o melhor de todos os cremes, a Bouvarine ${ }^{122}$. Num dos primeiros momentos do capítulo II, Pécuchet sonha à beira da fossa "montanhas de frutos, inundações de flores, avalanches de legumes”. No episódio da Bouvarine, os dois autodidatas

\footnotetext{
${ }^{121}$ Conforme as passagens de Gisèle Séginger: "No discurso, Flaubert prefere uma elaboração do sentido fundada na circulação de signos recorrentes que se organizam em redes e obrigam o leitor a fazer ele mesmo o trabalho de estabelecer as relações.” No original: “Au discours, Flaubert préfère une élaboration du sens fondée sur la circulation de signes récurrents qui s'organisent en réseaux et obligent le lecteur à faire lui-même le travail de mise en rapport." (2000, p. 179)/ "Narrativa paradoxal, esse romancee opera não transformações mas deslocamentos de um setor a outro do saber. E em cada capítulo prevalece uma lógica paradigmática: enumeração de experiências, enumeração de pesquisas de um mesmo tipo. No original: "Récit paradoxal, ce roman opère non des transformations mais des déplacements d'un secteur à l'autre du savoir. Et dans chaque chapitre prévaut une logique paradigmatique: énumération d'expériences, énumération de recherches d'un même type." Cf. o artigo de Séginger. "Forme romanesque et savoir. Bouvard et Pécuchet et les sciences naturelles". In: Revue Flaubert, n. 4, 2004, Não paginado.

122 "Enfin ils rêvèrent une crème, qui devait enfoncer toutes les autres. Ils y mettraient de la coriandre comme dans le kummel, du kirsch comme dans le marasquin, de l'hysope comme dans la chartreuse, de l'ambrette comme dans le vespetro, du calamus aromaticus comme dans le krambambuli; - et elle serait colorée en rouge avec du bois de santal. Mais sous quel nom l'offrir au commerce? Car il fallait un nom facile à retenir, et pourtant bizarre. Ayant longtemps cherché, ils décidèrent qu'elle se nommerait 'la Bouvarine'!” ( $B P$, p.113) /"Enfim eles sonharam com um creme, que devia acabar com todos os outros. Colocariam nele coentro como no kummel, kirsch como no marrasquim, hissop como no chartreuse, ambreta como no vespetro, cálamo aromático como no krambambuli; e o creme seria colorido de vermelho com madeira de sândalo. Mas qual nome utilizar no comércio? Pois era necessário um nome fácil de lembrar e, no entanto, singular. Depois de muito tempo de pesquisa, decidiram que se chamaria 'Bouvarine'!"
} 
imaginam os ingredientes, a cor e o nome de seu creme. Os momentos de sonho, bem como o de experiências com resultados grotescos estimulam as potencialidades ficcionais ${ }^{123}$.

O jardim de Bouvard e Pécuchet se bifurca em horticultura, agricultura e destilação e explode, junto com o alambique, em outros saberes:

Quand ils purent recouvrer la parole, ils se démandèrent quelle était la cause de tant d'infortunes, de la dernière surtout? - et ils n’y comprenaient rien, sinon qu'ils avaient manqué périr. Pécuchet termina par ces mots:

-“C’est que, peut-être, nous ne savons pas la chimie”. ${ }^{124}$ (BP, p. 115.)

Em apenas um capítulo, é construído um longo caminho de saberes. A interrogação do roteiro mostrado no Capítulo 1 desta dissertação se repete e se multiplica, e os personagens, diante de vários caminhos parecem escolher todos ao mesmo tempo, para continuarem sua busca pelo conhecimento. Flaubert teria dito uma vez: "Retiro-me para escrever um livro”. E outra: "Retiro-me para construir um labirinto". Flaubert morreu; ninguém encontrou o labirinto; a confusão do romance sugeriu-me que esse era o labirinto. ${ }^{125}$

\section{Um manual de instruções “definitivo”}

Procurei mostrar, no capítulo anterior, como Perec concebe sua obra e, sobretudo, LVME como uma “máquina de contar histórias” tanto no sentido da produção, com o trabalho intenso para incluir o discurso alheio em seu próprio, buscando também o jogo lúdico para estabelecer todos os elementos que fariam parte de LVME, quanto no da recepção de seu texto, pois o leitor pode trabalhar com as peças do escritor (contraintes, enigmas, quebracabeças) e prolongar o romance à sua maneira. Ainda no primeiro capítulo, essa “engrenagem” ficcional foi apresentada na composição de LVME, por meio dos procedimentos de escrita ligados à biblioteca virtual de Georges Perec. Nesta parte, convido o leitor a entrar na biblioteca imaginária do(s) romance(s) LVME.

\footnotetext{
123 "La fiction absorbe les savoirs en neutralisant leur finalité informative mais en libérant leur imaginaire pour stimuler ses potentialités fictionnelles." Cf. o artigo de Gisèle Séginger "La Tentation et les savoirs". In: Flaubert, n. 1, 2009.

124 “Quando puderam retomar a voz, perguntaram-se qual era a causa de tantos infortúnios, sobretudo do último? - e eles não entendiam nada, senão que eles não haviam morrido.

Pécuchet teminou com estas palavras:

- Talvez, é porque não sabemos química.”

125 Apropriação do seguinte trecho do conto “O jardim de veredas que se bifurcam”, de Jorge Luis Borges: “Ts'ui Pen teria dito uma vez: 'Retiro-me para escrever um livro.' E outra: 'Retiro-me para construir um labirinto.’ [...] Ts’ui Pen morreu; ninguém, nas dilatadas terras que foram suas, deu com o labirinto; a confusão do romance sugeriu-me que esse era o labirinto.” (BORGES, 2001, p. 109)
} 
Se cada capítulo de $B P$ podia ser associado à categoria de uma biblioteca, cada capítulo de LVME pode ser considerado, em primeiro lugar, um romance potencial que compõe esse volume com o subtítulo Romans (romances), como indica o próprio escritor no ano do lançamento do romance ${ }^{126}$. No entanto, trata-se de um subtítulo que não exerce a função usual de complementar o primeiro, mas que exerce a função de "perturbar” o título, afinal, qual a ligação de um manual de instruções (texto descritivo) com um romance plural (texto narrativo)? Seria este um manual para a vida ou para os romances? Um manual para ler romances ou para criar romances?

O “manual de instruções” ou o “modo de usar” que traduz o mode d'emploi do título está presente nesse livro-biblioteca, sobretudo nos paratextos e em episódios em que o livro aparece como objeto, materialmente. Os paratextos que compõem LVME são sustentados pela estrutura episódica presente no romance. O longo “Índice remissivo” presente no final desse livro, seguido pelo "Índice remissivo de algumas histórias contadas neste livro”, que elenca, em ordem alfabética, os títulos das histórias narradas no livro bem como o capítulo em que estão localizadas, é muito semelhante aos títulos dados por Rabelais em Gargantua e Pantagruel. À moda de Rabelais, os títulos das narrativas do Índice são genéricos e, de certa forma, resumem o enredo de cada uma delas, por exemplo: "História do acrobata que não queria descer mais do trapézio, 13”, ou “História da dançarina que fez aborto, 73”. Entretanto, não se trata de episódios ligados aos mesmos personagens, como no caso de Pantagruel, Gargântua e Bouvard e Pécuchet, que apresentei anteriormente. As histórias referem-se a diversos moradores do prédio localizado no número 11 da rua Simon-Crubellier.

Esses paratextos formados por Índices, Preâmbulo, Mapa do imóvel, Índex e Pósescrito orientam, em certa medida, a leitura de LVME. A primeira chave da leitura é apresentada no preâmbulo, em que o narrador descreve a teoria do quebra-cabeça:

En dépit des apparences, ce n'est pas un jeu solitaire: chaque geste que fait le poseur de puzzle, le faiseur de puzzle l'a fait avant lui; chaque pièce qu'il prend et reprend, qu'il examine, qu'il caresse, chaque combinaison qu'il essaye et essaye encore, chaque tâtonnement, chaque intuition, chaque

\footnotetext{
${ }^{126}$ De acordo com Perec, o subtítulo "romances” aponta para a multiplicidade de histórias criadas a partir de dois princípios de escrita iniciais: escrever um romance grande como Moby Dick e com pequenas peças para dar a ideia de um quebra-cabeças. (PEREC, 2003a, p. 207) Cf. a entrevista "Georges Perec: 'des règles pour être libre’”. Propos recueillis par Claude Bonnefoy, 1977. No ano seguinte, em outra entrevista, o escritor vai reforçar essa ideia da indicação da multiplicidade e potencialidade do romance logo no subtítulo: "É por isso que coloquei, na capa de La Vie mode d'emploi, 'romances' no plural. É um romance que conta romances, romances potenciais, os quais não serão todos necessariamente desenvolvidos.” No original: “C’est pourquoi j’ai mis sur la couverture de La Vie mode d'emploi 'romans', au pluriel. C'est un roman qui raconte des romans, des romans potentiels, qui ne seront pas tous forcément développés." (PEREC, 2003a, p. 240) Cf. a entrevista "La maison des romans”. Propos recueillis par Jean-Jacques Brochier, 1978.
} 
espoir, chaque découragement, ont été décidés, calculés, étudiés par l'autre. ${ }^{127}$ (LVME, p. 20)

Assim como o jogo do quebra-cabeça, a leitura não é um ato solitário. Mesmo quando feita em silêncio, há uma relação no mínimo entre dois: texto e leitor. ${ }^{128}$ É essa comunicação com o leitor que Perec pretende suscitar em seu livro enquanto jogo, já que trabalha com diferentes eventos, personagens, objetos que se movimentam no espaço fixo de um prédio como diferentes peças podem ser manipuladas para compor uma imagem fixa, a do romance. As peças do quebra-cabeça são classificadas de acordo com o corte, ou seja, a forma que apresentam, como os homenzinhos, as cruzes simples e as de Lorena, e são detalhes de uma imagem já pronta anteriormente. No entanto, apesar de trabalhar com “peças prontas”, como vimos no Cahier des Charges apresentado no capítulo anterior, Perec não prevê um quebracabeça perfeito, pois uma peça não se encaixará - algo semelhante ao que ele já fez na composição do romance, quando burla a regra do xadrez e pula um movimento para não completar cem capítulos. Vejamos o trecho da última parte, em que Bartlebooth, o personagem que monta os quebra-cabeças no romance, está morto com a última peça que faltava (?) para completar o jogo:

C’est le vingt-trois juin mille neuf cent soixante-quinze et il va être huit heures du soir. Assis devant son puzzle, Bartlebooth vient de mourir. Sur le drap de la table, quelque part dans le ciel crépusculaire du quatre cent trenteneuvième puzzle, le trou noir de la seule pièce non encore posée dessine la silhouette presque parfait d'un $\mathrm{X}$. Mais la pièce que le mort tient entre ses doigts a la forme, depuis longtemps prévisible dans son ironie même, d'un W. ${ }^{129}$ (LVME, p. 578)

\footnotetext{
127 “Apesar das aparências, não se trata de um jogo solitário: cada gesto feito pelo jogador do quebra-cabeça, o criador do quebra-cabeça o fez antes dele; cada peça que ele toma e retoma, que ele examina, que ele cuida, cada combinação que ele tenta e tenta mais uma vez, cada tateamento, cada intuição, cada esperança, cada desencorajamento foram decididos, calculados, estudados pelo outro."

${ }^{128}$ Em LVME e em diversas entrevistas, Perec aponta um projeto estético que reflete uma espécie de teoria ficcional da leitura. A teoria do quebra-cabeça do Preâmbulo junto da técnica do xadrez na composição do romance demonstram essa reflexão sobre como o leitor se relacionará com o texto. Nesse sentido, o uso desses jogos indicam o posicionamento do escritor sobre a leitura como uma parceria entre texto e leitor, como uma comunicação, não como um ato unidirecional. Não pretendo estender aqui a discussão sobre as teorias de leitura, pois estou me remetendo à questão da leitura no Preâmbulo de $L V M E$ apenas como um dos elementos que compõem a biblioteca imaginária do romance. Para uma exposição e discussão mais prolongada sobre o projeto estético de Perec e as teorias de leitura, remeto o leitor à dissertação de Samira Murad (2007), sobretudo ao capítulo 2 (p.41-66).

129 "É dia vinte e três de junho de mil novecentos e setenta e cinco e vão dar oito horas da noite. Sentado diante de seu quebra-cabeça, Bartlebooth acaba de morrer. Sobre a toalha de mesa, em alguma parte no céu crepuscular do quadringentésimo trigésimo nono quebra-cabeça, o buraco negro da última peça ainda não colocada desenha a silhueta quase perfeita de um X. Mas a peça que o morto tem entre os dedos, desde muito tempo prevista em sua própria ironia, possui a forma de um W.”
} 
O enigma fica para o leitor: nesse quebra-cabeça, há uma peça que falta ou uma peça que sobra? Podemos percorrer essas duas leituras ao mesmo tempo? Talvez sim, pela quantidade de peças que o leitor pode manipular para jogar com esse romance e pelos espaços deixados no texto para o leitor recriá-lo a seu modo. É por isso que o edifício, ou seja, o espaço destaca-se como eixo organizador de toda a obra. É como uma casa de bonecas ${ }^{130}$ na qual podemos criar diversos mundos imaginários.

O espaço do prédio permite a ligação entre as histórias tão distantes do passado, do presente e até do futuro de alguns de seus habitantes. A organização temporal da obra não é cronológica, mas está intimamente ligada ao espaço, já que cada apartamento disparará uma memória diferente, sempre a partir dos objetos (que já estiveram ou que estão) presentes em cada apartamento. Por se tratar de um espaço que reúne diferentes tempos e personagens, poderíamos tratá-lo como uma metáfora da biblioteca ${ }^{131}$, cujos livros são os capítulos, ou, como diria Jean Roudaut (1999, p. 31), as peças do puzzle:

Os livros, em uma biblioteca, são peças de um quebra-cabeça, em que há sempre elementos de sobra. A felicidade que procura a contemplação das bibliotecas consiste na inexistência da ordem, e no fato de que qualquer classificação é provisória. ${ }^{132}$

\footnotetext{
${ }^{130}$ Perec comenta que a estrutura de seu livro-edifício partiu justamente da imagem de uma casa de bonecas e de um desenho de Steinberg: "As fontes propriamente ditas são um catálogo de casas de bonecas vitorianas (se for rico um dia, comprarei uma dessas casas de bonecas, que reconstituem em corte todos os cômodos de um imóvel) e um desenho de [Saul] Steinberg [The art of living, 1952] o qual me inspirou em Espèces d'espaces [...]." No original: "Les sources proprement dites, c'est un catalogue de maisons de poupée victoriennes (si je suis riche un jour, j'achèterai une de ces maisons de poupée, qui reconstituent en coupe tous les appartements d'un immeuble), c'est un dessin de Steinberg [The Art of living, 1952] dont je m'étais inspiré dans Espèces d'espaces [...]”. (PEREC, 2003a, p. 246) Cf. a entrevista “Georges Perec: 'J'ai fait imploser le roman’”. Propos recueillis par Gilles Costaz, 1978. Espèces d'espaces é um livro de Perec publicado em 1974 e que reflete sobre como nos relacionamos com diferentes espaços onde vivemos, como casa, quarto, bairro, etc.

131 O escritor angolano Gonçalo M. Tavares também criou ao longo da primeira década de 2000 livrosbibliotecas, cuja coleção representa o espaço de um bairro de escritores. Uma série de livros de narrativas curtas intitulados com nomes importantes da literatura: Valéry, Brecht, Calvino, Breton, Eliot, entre outros. Sua biblioteca imaginária pessoal também é condensada no livro Biblioteca, que reúne uma espécie de pastiche em micronarrativas da obra de vários escritores "visitados” por Tavares. A forma como Tavares trabalha o espaço do bairro-biblioteca se assemelha muito ao trabalho de Georges Perec em torno do espaço do edifício como biblioteca, mesmo que neste caso o espaço esteja condensado em um só livro como La Vie mode d'emploi. Sobre Gonçalo Tavares, confira o artigo de Telma Maciel da Silva, que analisa essa série de livros $O$ Bairro e Biblioteca. SILVA, T. M. da. Gonçalo M. Tavares: brincando de ser clássico. Revista Criação \& Crítica, n. 6, p. 1-17, 2011. Disponível em: <http://www.fflch.usp.br/dlm/criacaoecritica/dmdocuments/CC_N6_TMSilva.pdf> Acesso em 11 jun. 2012.

132 “Les livres, dans une bibliothèque, sont les pièces d'un puzzle, où il y a toujours quelques éléments en trop. Le Bonheur que procure la contemplation des bibliothèques tient à ce que l'ordre n'y règne pas, et que tout classement est provisoire.” Cf. o artigo de Jean Roudaut, "Les bibliothèques sont partout”. In: Magazine Littéraire, n. 349, Paris, décembre 1999.
} 
Ainda nessa chave de um romance metalinguístico, que apresenta em seu cerne uma discussão sobre o estatuto romanesco, poderia relacionar a imagem desse edifício sem fachada (ou dessa casa de boneca) no(a) qual Perec se baseou para compor o prédio da Rua Simon Crubellier, à estrutura do próprio romance, que apresenta aqueles paratextos já mencionados anteriormente. Dessa forma, os índices, o mapa, o pós-escrito, etc. também revelam um “romance sem fachada”. Um romance que brinca com as próprias regras do romance, apresentando paratextos que desvendariam a criação do livro e encaminhariam a leitura, ou seja, um manual ou modo de usar LVME. É nesse sentido também que Perec fala sobre o uso e a presença de jogos em $L V M E$ em várias entrevistas. O jogo, para ele, é algo mais próximo da cooperação, da criação, do lúdico, ou seja, dá acesso à imaginação a partir de regras (como o próprio romance ou a Literatura ${ }^{133}$ ). Por meio dos paratextos e de "pistas" ao longo do romance, Perec enseja o aspecto didático de seu texto literário, como ele mesmo deixa entender em várias entrevistas, sobretudo, quando é questionado sobre os jogos com o leitor presentes em LVME (jogos de palavras, de citações, etc.), por exemplo: "Sim, são enigmas a resolver e muitas soluções são dadas no índex no fim do romance.”134

\section{Retalhos de livros e outros detalhes de biblioteca que compõem a Vida}

Além das citações e alusões previstas para povoar o romance, como já vimos no Cahier des Charges, ao longo de LVME notamos a presença da biblioteca e da materialidade dos livros na "vida” das personagens. Daniel Riou (2009), em seu artigo "Les bibliothèques de Georges Perec ou le mal de archive”, além de discutir questões referentes à biblioteca real de Perec $^{135}$, também resume bem as formas de ficcionalização da biblioteca em LVME e relaciona esse tema aos da perda, da memória e do arquivo, já presentes em $W$ ou Le souvenir d'enfance (1975) e Je me souviens (1978). Retomarei alguns exemplos desse artigo a seguir, para expandi-los e agregá-los aos trechos que também considero significativos para ilustrar o tema da biblioteca no romance perecquiano aqui focalizado. Riou levanta os seguintes exemplos de presença da biblioteca que optei por classificar desta forma:

\footnotetext{
${ }^{133}$ Nesse sentido, ele afirma que seu verdadeiro jogo é a literatura: "Mon veritable jeu, c'est la littérature et le jeu que je joue avec elle.” (PEREC, 2003a, p. 249). Cf. a entrevista “Georges Perec: 'J'ai fait imploser le roman’”. Propos recueillis par Gilles Costaz, oct. 1978.

134 "Incidemment, vous avez laissé des petits jeux à la disposition du lecteur tout au long du récit principal? Oui, ce sont des énigmes à résoudre et plusieurs solutions sont données dans l'index à la fin du livre.” (PEREC, 2003a, p. 270). Cf. a entrevista "la vie: règle du jeu”. Propos recueillis par Alain Hervé, 1978.

${ }^{135}$ Sobre a biblioteca real de Perec, cf. o Capítulo 3 desta dissertação, sobretudo, o tópico 3.2.1.
} 
a) em personagens cujas profissões ou funções eram ligadas a esse espaço, como: Grégoire Simpson $^{136}$, estudante de História que fazia bicos e que, em um deles, assumiu a função de sub-bibliotecário da biblioteca da Opéra, onde fazia e organizava recortes de jornais e revistas do arquivo de Henri Astrat; o bibliotecário aposentado M. Échard ${ }^{137}$, que tem a obsessão de reunir provas de que Hitler ainda é vivo; e Cinoc $^{138}$, responsável por atualizar os Dicionários Larousse e cujo episódio será analisado no Capítulo 3 desta dissertação. Incluiria também nesta categoria os personagens pesquisadores, autodidatas e colecionadores maníacos ${ }^{139}$ que figuram no prédio de $L V M E$ e que se assemelham muito à dupla de Flaubert, por exemplo: Fernand Beaumont ${ }^{140}$, arqueólogo que buscava encontrar traços da legendária cidade de Lebtit, que teria sido capital da Espanha, e que, para isso, não só estuda diversas fontes como participa de escavações; Morellet $^{141}$, que após exercer diversas atividades tornou-se "prisioneiro do demônio da pesquisa”, realizando diversas experiências de física e química; e Léon Marcia, marido da dona da loja de antiguidades que conheceremos no próximo capítulo, um idoso que só frequentou a escola até os nove anos e, mesmo doente, ainda lia com voracidade e memorizava "tratados de gramática grega, histórias da Polônia, poemas épicos em vinte e cinco cantos, manual de esgrima ou de horticultura, romances populares e dicionários enciclopédicos [...]”"142;

b) como objeto, quando aparece como móvel em L que divide o ateliê do apartamento do pintor Hutting ${ }^{143}$. O aspecto mais curioso dessa estante-biblioteca é que ela não comporta livros, apenas bibelôs, objetos kitsch dos anos 1930, cartões-postais e obras do pintor, que na verdade são cópias de quadros famosos. Em vez de exercer sua função original de “arquivo de

\footnotetext{
${ }^{136}$ Cf. capítulo LII - Plassaert, 2, de LVME. p. 287-295.

${ }^{137}$ Cf. capítulo XXX - Marquiseaux, 2 e XCI - Caves, 5, de LVME. p. 172-175 e 534-536, respectivamente.

${ }^{138}$ Cf. capítulo LX - Cinoc, 1, de LVME, p. 345-352.

139 "Il y a plusieurs collectionneurs dans cet immeuble, et souvent plus maniaques encore que les personnages de ce tableau; Valène lui-même a longtemps conservé les cartes postales que Smautf lui envoyait à chaque fois qu'il faisait escale. Il en avait une de Newcastle-upon-Tyne, justement et une autre de la Newcastle australienne, en Nouvelle-Galles du Sud.” (LVME, p. 37)
}

${ }^{140}$ Cf. capítulo III - Beaumont, 1, de LVME, p. 25-9.

141 "Débarrassé de tout souci financier, mais saisi par le démon de la recherche, Morellet mit à profit son temps libre pour se livrer, chez lui, à des expériences de physique et de chimie dont ses longues années de préparateur semblaient l'avoir particulièrement frustré.”Cf. capítulo VII - Chambres de bonne, 2/Morellet, de LVME, p. 448.

142 "Il lui suffisait de lire quelque chose une fois pour s'en souvenir à jamais, et il avalait avec la même rapidité, la même voracité et la même intelligence des traits de grammaire grecque, des histories de la Pologne, des poèmes épiques en vingt-cinq chants, des manuels d'escrime ou d'horticulture, des romans populaires et des dictionnaires encyclopédiques [...].”(LVME, p. 219)

${ }^{143}$ Cf. capítulo XI - L’atelier de Huting, 1, de LVME, p. 63-66. 
livros”, o móvel transforma-se em um “arquivo de coisas” que também contam histórias e refletem a intimidade de uma biblioteca pessoal. Neste ponto, a biblioteca deixa de ser armazém de livros para se abrir ao espaço da coleção em geral. O outro exemplo é o da biblioteca de James Sherwood $^{144}$, tio-avô de Bartlebooth, biblioteca essa que Priscilla Sherwood mandou vir para a Inglaterra como um objeto "entre outros móveis e alguns objetos da mesma procedência”, os quais depois foram parar no apartamento de Bartlebooth;

c) como espaço, a biblioteca deixa de ter ligação específica com o saber, com o ato da leitura e com a memória íntima dos personagens que a possuem ou nela atuam para se tornar um ambiente meramente decorativo. É caso da biblioteca da viúva Mme. Moreau ${ }^{145}$, que depois de enriquecer, contrata um decorador (Henry Fleury) para reformar a sua casa. Fleury, então, compõe a biblioteca e a sala de fumar como um ambiente digno de revista de decoração, só que de tão exagerado e extravagante que fica, o espaço perde sua funcionalidade para dar lugar apenas à beleza e ao status de ter aquele ambiente na casa.

d) como procedimento discursivo, Riou (2009) destaca o papel da mise en abyme ${ }^{146} \mathrm{e}$ levanta dois exemplos: o primeiro, no hall do prédio, quando uma mulher observa a foto de James Sherwood que o retrata ao lado da estante de uma biblioteca e, a partir dessa foto, é narrado o episódio desse personagem em busca de objetos únicos no mundo; e o segundo, da casa de bonecas que Fleury colocou na biblioteca de Mme. Moreau. Uma casa que possuía um metro de altura por 90 centímetros de largura e que apresentava, em seu interior, uma minibiblioteca de carvalho com alguns badulaques e a Encyclopaedia Britannica e o New Century Dictionary.

\footnotetext{
${ }^{144}$ Cf. capítulo XXII - Le hall d'entrée, de LVME, p. 113-128.

${ }^{145}$ Cf. capítulo XXIII - Moreau, 2, de LVME, p. 129-135.

146 “Outre le procédé de mise en abîme, largement exploité par les nouveaux romanciers - la bibliothèque tournante présente dans un des appartements et apparaissant aussi dans la description d'une photo observé par la concierge - on est face à une logique implacable, qui fait que les éléments constitutifs du récit, personnages et objets, trouvent leur place dans un réseau extrêmement serré et sans failles de relations logiques justifiant leur voisinage ou leur contiguïté occasionnelle, en tout cas contingente, chacun d'eux, personnage ou objet, gardant une manière d'autonomie monadique parfois absurde, qui donne au récit son caractère pittoresque, insolite, et/ou de liste dans un texte." (RIOU, 2009, p. 465). Há diversos exemplos de mise en abyme em LVME, os mais explícitos estão em pinturas e imagens, como um cartaz presente na sala de estar de Mme. Beaumont, que "representa quatro monges de fisionomia glutona sentados à mesa em torno de um camembert, na etiqueta do qual quatro monges de fisionomia glutona - os mesmos - estão de novo sentados à mesa. A cena repete-se, distintamente, até a quarta vez." (PEREC, 2009, p. 21-2) No original: "L'une d'entre elles représente quatre moines 'a la mine gourmande attablés autour d'un camembert sur l'étiquette duquel quatre moines 'a la mine gourmande - les mêmes - sont de nouveau attablés. La scène se répète, distinctement, jusqu'à la quatrième fois.” (LVME, p. 26)
} 
O uso de mise en abyme em LVME é bastante coerente com a ficcionalização da biblioteca, pois mostra uma reflexão do romance dentro do romance, dentro da literatura e dentro de uma época, como afirma Butor (1974, p. 201):

Primeiro leitor, o escritor começa a propósito de seu próprio trabalho o que ele sabe fazer com o de outrem. Sua atividade vai refletir-se como num espelho. Em romances, ouviremos falar pessoas que escrevem ou lêem romances.

Esta reflexão é uma das características fundamentais da arte contemporânea: romance do romance, teatro do teatro, cinema do cinema...; esta característica a aparenta estreitamente com a de certas épocas anteriores, a arte barroca em particular; nos dois casos, essa volta interrogativa sobre si mesma é uma resposta a uma mudança da imagem do mundo,

volta que não implica nenhum fechamento, nenhuma cegueira, quanto aos outros homens, não só porque é sempre entre eles que o escritor nos mostra seus escritores, mas sobretudo porque, todos esses outros sendo em certa medida já escritores, ele nos fala deles ao mesmo tempo, [...]. A composição em abismo simples (romance por assim dizer só do romance) é apenas um primeiro grau.

Se “contar a biblioteca é dar vida às suas lembranças”147, como afirma Cortanze (1999), contar as lembranças é estabelecer uma relação de biblioteca, de rede de leituras, de tempos e espaços. Nesse sentido, Gleize (1992) afirma que trabalhar a mise en abyme com livros é integrar ao texto uma forma de diálogo com a biblioteca. A autora define esse trabalho como uma "forma particular de intertextualidade", pois "pode então se instaurar, entre o romance representante e o livro representado, uma relação de comentário ou de citação"148.

Um recurso muito semelhante à mise en abyme é a digressão, utilizada para inserir "lembranças” na narrativa, ou seja, para enxertar mais histórias dentro da história principal do capítulo, e também para colocar diante dos olhos do leitor, materialmente, o que o personagem está lendo ou possui em seu apartamento. Perec classifica esse procedimento como cinematográfico $^{149}$, já que a "câmera” oferece ao leitor o olho do narrador e/ou do

\footnotetext{
147 "Raconter la bibliothèque, c'est y faire vivre ses souvenirs." Cf. o artigo de Gérard de Cortanze, "De la bibliothèque comme personage de roman”. In: Magazine Littéraire, déc. 1999. p. 54.

148 “Dès lors qu'intervient, dans le roman, le texte d'un livre lu par un personage, celui-ci peut alors s'instaurer, entre le roman représentant et le livre représenté, une relation de commentaire, de transformation ou de citation.” (GLEIZE, 1992, p. 11)

149 "Il y a des côtés cinématographiques de la narration, des sortes de travellings avant: ainsi, un petit garçon, sur une marche de l'escalier, lit le journal de Tintin; la caméra s'avance, et s'insère dans le livre l'histoire qu'il est en train de lire.” (PEREC, 2003a, p. 238) Cf. a entrevista "La maison des roman”. Propos recueillis par JeanJacques Brochier, Le Magazine Littéraire, n. 141, "Nietzsche”, octobre 1978. O trecho mencionado por Perec aparece no cap.LXXVIII - Escaliers, 10, de LVME, p. 440-449.
} 
personagem, focalizando um texto ou fazendo um flash-back a partir de determinado objeto ou texto dentro da narrativa.

Há inúmeros casos desse tipo ao longo de LVME, geralmente marcados graficamente por meio de fontes diferentes, ilustrações, recorta e cola de página de livro, de anúncio de farmácia, de revista científica, de catálogo, de correspondência, etc. Um dos exemplos de narrativa dentro da narrativa que me chamou atenção e que recorto e colo aqui é o da nota de rodapé presente no episódio de Olivia Rorschash, no capítulo LXXXI. Primeiramente, há uma longa e detalhada descrição do quarto de Olivia, com direito à digressão a partir de uma fotografia sobre sua carreira de atriz, em seguida, a descrição do momento e do aspecto físico atual da personagem, que está prestes a viajar e relê uma lista de instruções que deixará aos cuidados de Jane Sutton (au pair). Uma das recomendações é “comprar queijo Edam curtido para Polonius e não se esquecer de levá-lo uma vez por semana ao senhor Lefèvre para sua aula de dominó ${ }^{1 »,}$, com a referência a uma nota de rodapé:

1. Polonius est le $43^{\mathrm{e}}$ descendant d'un couple de hamsters apprivoisés que Rémi Rorschash offrit à Olivia peu de temps après avoir fait sa connaissance: ils avaient vu dans un music-hall de Stuttgart un montreur d'animaux et avaient été à ce point passionnés par les prouesses sportives du hamster Ludovic - aussi à l'aise aux anneaux qu'à la barre fixe, au trapèze ou aux barres parallèles - qu'ils avaient demandé à l'acheter. Le montreur, Lefèvre, avait refusé mais leur avait vendu un couple - Gertrude et Sigismond - auquel il avait appris à jouer aux dominos. La tradition s'était perpétuée de génération en génération, les parents apprenant chaque fois spontanément à jouer à leurs rejetons. Malheureusement, l'hiver précédent, une épidémie avait presque entièrement détruit la petite colonie: l'unique survivant, Polonius, ne pouvait jouer seul et, qui plus est, était condamné à dépérir s’il ne pouvait continuer à pratiquer son passetemps favori. Aussi fallait-il, une fois par semaine, le mener à Meudon chez le montreur qui, aujourd'hui retiré, continuait pour son seul plaisir à élever des petits animaux savants. ${ }^{150}$ (LVME, p. 466-7)

A princípio, a recomendação não parece insólita: comprar queijo para um senhor e levá-lo às aulas de dominó. No entanto, ao ler a nota de rodapé, temos uma explicação - o

\footnotetext{
150 “1 Polonius é o quadragésimo terceiro descendente de um casal de hamsters domesticados que Rémi Rorschash ofereceu a Olivia pouco tempo depois de conhecê-la: haviam visto num teatro de variedades de Stuttgart um domador de animais e ficaram de tal forma siderados pelas proezas esportivas do hamster Ludovic à vontade tanto nas argolas quanto na barra fixa, tanto no trapézio quanto nas paralelas - que quiseram comprálo. O domador, Lefèvre, recusou-se, mas acabou por lhes vender um casal - Gertrude e Sigismond - ao qual ensinara a jogar dominó. A tradição manteve-se de geração a geração, com os pais ensinando em cada uma delas espontaneamente o jogo a seus filhotes. Infelizmente, no último inverno, uma epidemia quase dizimara por completo a pequena colônia: o único sobrevivente, Polonius, não podia jogar sozinho e, mais ainda, estava condenado a perecer se não pudesse continuar a praticar seu passatempo favorito. Por isso, era necessário, uma vez por semana, levá-lo a Meudon a um domador que, embora aposentado, continuava até hoje, para sua satisfação pessoal, a treinar esses animaizinhos inteligentes.” (PEREC, 2009, p. 473)
} 
fato de Polonius ser um hamster -, a narrativa do domador Lefèvre, que treinava animais para atividades fora do comum, como ginástica e jogar dominó, e a breve genealogia de Polonius, último sobrevivente de uma família de hamsters jogadores de dominó. O comentário no pé da página, que seria auxiliar, muda o efeito da instrução presente na lista de tarefas cotidianas, como comprar coca-cola, trocar água das flores e limpar o lustre, em algo extraordinário aos olhos do leitor.

Além da nota de rodapé, LVME ficcionaliza ainda outro recurso que visa remeter o leitor ou incluir uma informação adicional no texto: a bibliografia. No capítulo IX - Quartos de empregada, 3, que descreve o quarto de Joseph e Ethel, empregados do pintor Hutting, o leitor é convidado a buscar mais informações sobre esse artista no final do capítulo:

SI VOUS VOULEZ EN SAVOIR DAVANTAGE:

BOSSEUR, J. - Les Sculptures de Franz Hutting. Paris, Galerie Maillard, 1965.

JACQUET, B. - Hutting ou de l'Angoisse. Forum, 1967, 7.

HUTTING, F. - Manifeste du Mineral art. Bruxelles, Galerie 9 + 3, 1968.

HUTTING, F. - Of Stones and Men. Urbana Museum of Fine Arts, 1970.

NAHUM, E. Towards a Planetary Consciousness: Griller, Hagiwara, Hutting. In: S. Gogolak (es.), An Anthology of Neo-creative Painting. Los Angeles, Markham and Coolidge, 1974.

NAHUM, E. - Les Brumes de l'Étant. Essai sur la Peinture de Franz Hutting. Paris, XYZ, 1974.

XERTIGNY, A. de - Hutting portraitiste. Cahiers de l'Art Nouveau. Montreal, 1975, $3 .^{151}$ (LVME, p. 59)

Assim como em $B P$, a temática da pesquisa e da classificação é muito presente em LVME. Desde a caracterização dos personagens até o trabalho discursivo, observamos que Flaubert, "para desfazer a autoridade das palavras, ensaia um tipo de texto crítico ainda inédito: este encontraria sua força por não possuir comentários, narrativas ou elo discursivo" ${ }^{152}$. Mesmo com a falta de elos discursivos provocado por um trabalho, sobretudo, com a acumulação de frases e afirmações tiradas do discurso alheio que se chocam ou se assemelham, mas não chegam à conclusão alguma, não seria possível atribuir o adjetivo fragmentário a BP. Já em $L V M E$, o aspecto fragmentário é bastante trabalhado, inclusive com uma experimentação discursiva que produz um texto que comporta o que é da ordem do

\footnotetext{
151 "SE VOCÊ QUER SABER MAIS SOBRE ISSO.”

${ }^{152}$ Como diria Jacques Neefs sobre BP, "a ideia forte da obra é precisamente ter feito passar essa aporia da investigação em forma de narrativa e de obra.” NEEFS, J. Noter, classer, briser, montrer, les dossiers de Bouvard et Pécuchet. In: NEEFS; DIDIER, 1990, p. 73.
} 
romance (texto narrativo) e o que é específico de textos descritivos e explicativos (manual, nota de rodapé, bibliografia, etc.).

Também mencionei a presença material de livros dentro de LVME. Esse recurso abre mais um leque de exemplos da biblioteca imaginária do romance, já que o leitor é convidado a compartilhar da leitura do personagem e da visão do narrador em seu estado "puro", sem as nuances impostas pelo recurso da descrição, ou seja, com a sensação de estar diante do texto tal qual ele se apresenta para o personagem ou narrador. Destaco a seguir três das várias ocorrências desse tipo: o primeiro jornal da pilha que Dr. Dinteville separou para os estudantes recolherem para vender; o guia do Egito que a personagem Adèle Plassaert está lendo chamado Libvre mangificque dez Merveyes que pouvent estre vuyes es La Égipte (Lyon, $1560)^{153}$, em francês antigo, e que está aberto em uma página dupla com quatro verbetes seguidos de suas respectivas descrições: Hieroglyphicques, Obélisces, Pyramides e Catadupes du Nil; uma pasta de arquivo no chão da sala de estar da senhora Beaumont que está aberta numa página repleta de equações:

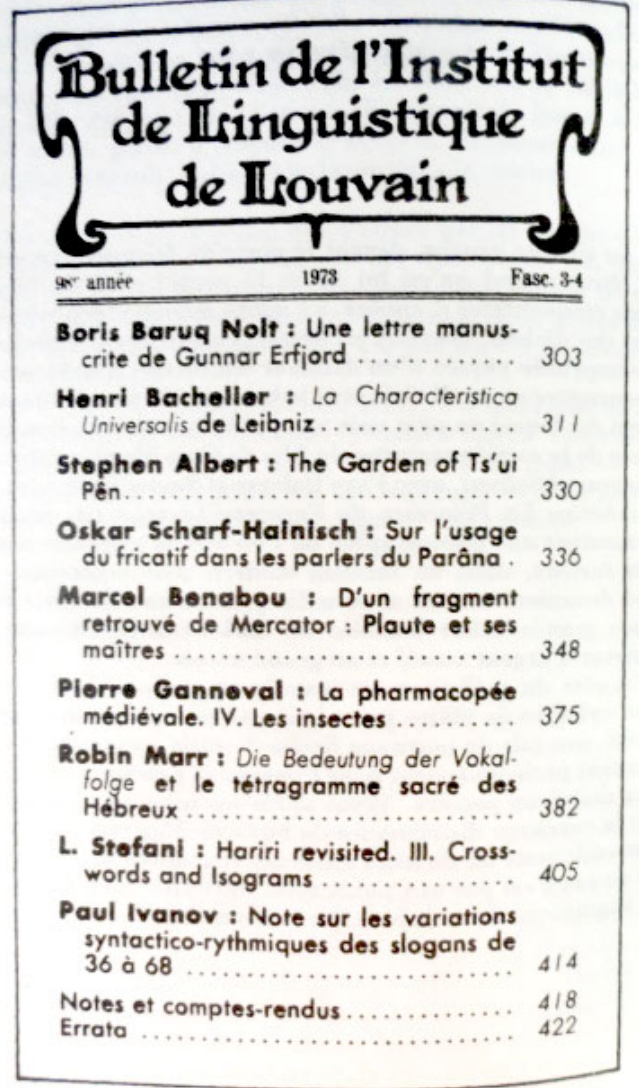

Figura 3. LVME, p. 319. Chapitre LVI - Escaliers, 8
Si $f \in \operatorname{Hom}(v, \mu)($ resp. $g \in \operatorname{Hom}(\xi, v))$ est un morphisme homogène dont le degré est la matrice $\alpha$ (resp. $\beta), f$ og est homogène et son degré est matrice produit $\alpha \beta$.

Soient $\alpha=\left(\alpha_{i j}\right), l \leq i \leq m, l \leq j \leq n ; \beta=\left(\beta_{k l}\right), l \leq k \leq n, l \leq 1 \leq p$ $(|\xi|=p)$, les matrices considérées. Nous supposons que l'on a $f=\left(f_{l}, \ldots, f_{m}\right) g=\left(g_{l}, \ldots, g_{n}\right)$, et soit $h \sqcap \rightarrow \xi$ un morphisme $\left(h=h_{l}, \ldots, h_{p}\right)$.

Soit enfin $(a)=\left(a_{l} \ldots, a_{p}\right)$ un élément de $A^{p}$. Évaluons, pour tout indice $i$ entre $l$ et $m(|\mu|=m)$ le morphisme $x_{i}=f_{i} \circ g$ o $\left(a_{l} h_{l}, \ldots, a_{p} h_{p}\right)$. On a d'abord

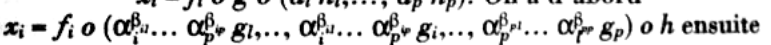

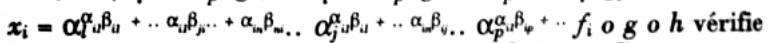
donc l'égalité d'homogénéité de degré $\alpha \beta$ ([1.2.2.])

Figura 4a. $L V M E$, p. 26. Chapitre II - Beaumont, 1

Se $f \in \operatorname{Hom}(v, \mu)$ (resp. $g \in \operatorname{Hom}(\xi, v)$ ) for um morfismo homogêneo cujo grau é a matriz $\alpha$ (resp. $\beta$ ), fo g é homogêneo, e seu grau é matriz produto $\alpha \beta$.

Sejam $\alpha=\left(\alpha_{i j}\right), l \leq i \leq m, l \leq j \leq n ; \beta=\left(\beta_{k j}\right), l \leq k \leq n$, $l \leq 1 \leq p(|\xi|=p)$, as matrizes consideradas. Suponhamos que se tenha $f=(f, \ldots f) g=\left(g_{0} \ldots, g\right)$ e seja $b \pi \rightarrow \xi$ um morfismo $\left(b=b_{p}, \ldots b_{p}\right)$. Por fim, seja $(\alpha)=\left(\alpha_{i} \ldots, \alpha_{p}\right)$ um elemento de A . Calculemos, para qualquer índice $i$ entre $l$ e $m(|\mu|=m)$, o morfismo

$$
x_{i}=f_{i} \circ g \circ\left(\alpha_{i} b_{p}, \ldots \alpha_{p} b_{p}\right) .
$$

Temos primeiro

$$
x_{i}=f_{i}\left(\boldsymbol{\alpha}_{i}^{\beta_{H}} \ldots \boldsymbol{\alpha}_{p}^{\beta_{p}} g_{i}, \ldots, \boldsymbol{\alpha}_{i}^{\beta_{A}} \ldots \alpha_{p}^{\beta_{i p}} g_{i}, \ldots, \boldsymbol{\alpha}_{p}^{\beta_{p} t} \ldots \boldsymbol{\alpha}_{i}^{\beta_{p p}} g_{p}\right) \circ b
$$

e em seguida

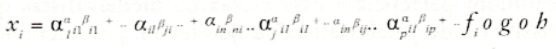

verifica pois a igualdade de homogeneidade de grau $\alpha \beta$ ([1.2.2.])

Figura 4b. Tradução de PEREC, 2009, p. 21

${ }^{153}$ Cf. ch. LIV - Plassaert, 3, de LVME, p. 302-9. 
Essas reproduções de páginas de livros, que vimos nos exemplos anteriores, ou mesmo de anotações dos personagens, de cartazes e anúncios, entre outras, que encontramos ao longo de $L V M E$ promovem uma suspensão da narrativa para abrir espaço para a contemplação desses elementos que parecem ter sido recortados e colados pelo narrador. Segundo Compagnon (2007, p. 11), o recorte e a colagem são “o modelo do jogo infantil” e "experiências fundamentais com o papel, das quais a leitura e a escrita não são senão formas derivadas, transitórias, efêmeras”, pois a partir do papel, da tesoura e da cola, é possível construir "um mundo à minha imagem, um mundo onde me pertenço, e é um mundo de papel”. Essas duas atividades, recortar e colar, estão intimamente ligadas, primeiramente, à teoria do puzzle, já que o narrador afirma que é a sutileza do corte da peça que caracteriza o jogo:

[...] ce n'est pas le sujet du tableau ni la technique du peintre qui fait la difficulté de puzzle, mais la subtilité de la découpe, et une découpe aléatoire produira nécessairement une dificulté aléatoire, oscillant entre une facilité extrême pour les bords, les détails, les taches de lumière, les objets bien cernés, les traits, les transitions, et une lumière, les objets bien cernés, les traits, les transitions, et une difficulté fastidieuse pour le reste: le ciel sans nuages, le sable, les labours les zones d'ombre, etc. ${ }^{154}$ (LVME, p. 18 e 240)

Em segundo lugar, as atividades de recortar e colar estão ligadas à repetição, pois esse mesmo trecho, assim como o restante do preâmbulo, é copiado e colado em outro momento do romance: no capítulo XLIV, episódio que narra a história de Gaspard Winckler, o criador de puzzles, também um dos personagens centrais de $L V M E$, ao lado de Bartlebooth. Como repetição, o recorte e a colagem aproximam-se da atividade da citação, já que um fragmento é retirado de seu lugar original para ser incorporado a um novo local. No entanto, a escolha da citação geralmente é refletida para incorporar-se "harmonicamente” ao novo texto, seja como exemplo, como explicação, como ponto de apoio ou de discórdia da nova costura de palavras e frases. Por esse motivo, podemos falar de citações explícitas (marcadas graficamente por itálico ou entre aspas) e implícitas (aquelas que Perec escolhe dentre suas leituras para passarem despercebidas de nossa leitura, por exemplo). Podemos inclusive transformar as citações em paráfrases, dizendo com nossas palavras a mensagem do trecho escolhido. Será

\footnotetext{
154 “Não é o assunto do quadro nem a técnica do pintor que fazem a dificuldade do puzzle, mas a sutileza do corte, e um corte aleatório produzirá necessariamente uma dificuldade aleatória, oscilando entre uma facilidade extrema para as bordas, os detalhes, as manchas de luz, os objetos bem definidos, os traços, as transições, e uma dificuldade fastidiosa para o resto: o céu sem nuvens, a areia, a pradaria, as lavouras, as zonas de sombras, etc.” Vale ressaltar que as imagens das peças que seguem ilustrando a teoria do puzzle são ligeiramente diferentes no preâmbulo e no episódio de Winckler.
} 
que as páginas inteiras que são recortadas e coladas em $L V M E$, como a página do livro de equações, a capa da revista de linguística, os verbetes do livro sobre o Egito em francês antigo possuem o mesmo estatuto da citação? Na verdade, esse tipo de reprodução no romance implica em uma tensão diferente da citação, pois, de acordo com Butor (1974, p. 229):

\begin{abstract}
A reprodução de uma página, ou mesmo de uma linha no interior de uma outra página, permite um corte óptico cujas propriedades são bem diferentes das do corte habitual das citações. Ele permite introduzir no texto novas tensões, as mesmas que experimentamos tão frequentemente hoje em dia, nas cidades cobertas de slogans, de títulos e de anúncios, barulhentas de canções e discursos transmitidos, aquelas sacudidas que sentimos quando é brutalmente ocultado o que estávamos lendo ou escutando.
\end{abstract}

Nada mais coerente com esse "manual da vida em romances" do que esses fragmentos de objetos e livros com os quais os personagens se relacionam. A Vida é composta por Perec como uma biblioteca falando de coisas e, dentro dela, há uma segunda falando dos livros, e por aí podem cavar-se outros tantos vazios ${ }^{155}$.

\title{
Os lugares-comuns dos livros-bibliotecas
}

Ao longo deste capítulo, visitamos alguns temas em comum nesses romances que ficcionalizam o espaço das bibliotecas. Conhecemos personagens autoditadas, pesquisadores, leitores e colecionadores que buscam acumular saberes e coisas como busca principal de suas vidas entre linhas e livros. Observamos de que maneira BP e LVME mimetizam a biblioteca por meio da inclusão e transformação de discursos alheios trabalhados em procedimentos formais que questionam o estatuto romanesco: o efeito enciclopédico presente na estrutura episódica de $B P$, a multiplicação de um romance em vários em $L V M E$, a presença de livros reais ou imaginários que são citados ou reproduzidos materialmente no romance... Para sintetizar as ideias e imagens apresentadas nessa visita à biblioteca imaginária, sugiro uma breve relação de lugares-comuns dos livros-bibliotecas $L V M E$ e $B P$.

\section{Hibridização}

O veneno flaubertiano que é rejeitado por seus contemporâneos, será inoculado mais tarde em muitos leitores, sobretudo a partir do século XX. Muitos escritores também

${ }^{155}$ Apropriação de trecho do ensaio "Crítica e invenção", de Michel Butor (1974, p. 196): "No interior da primeira biblioteca falando das coisas, há uma segunda falando dos livros, e aí podem cavar-se outros tantos vazios.” 
infringirão a linearidade temporal típica do romance e assumirão o ceticismo flaubertiano de forma ativa ${ }^{156} \mathrm{e}$ - por que não dizer - lúdica, no que diz respeito às relações entre diferentes discursos e métodos adotados na escritura. Além disso, utilizarão o conhecimento como multiplicidade, um espaço de relações e discussões abertas.

Ao contrário da literatura medieval, por exemplo, que pretendia definir a relação entre os saberes de forma ordenada e estável, o que me encanta (e angustia) na literatura do século XX é justamente a multiplicidade dos conhecimentos que se cruzam, se chocam, se relacionam em diferentes estilos de expressão. Os saberes, nos livros modernos, são como sementes envenenadas que geram a multiplicidade de espécies a partir de cross-overs inusitados (como no caso dos melões híbridos e das couves-monstro de Bouvard e Pécuchet).

Além disso, tanto em Flaubert quanto em Perec, a estrutura episódica resultou em mistura de gêneros. Em BP, resultou num romance-enciclopédia cuja composição discursiva é formada por teorias, opiniões, axiomas que são mesclados no discurso dos personagens e do narrador, que apresenta, inclusive, em grande parte das edições, alguns paratextos ligados à cópia, como o Dictionnaire des idées reçues, L’Album de La Marquise, Le Catalogue des Idées Chics, que fariam parte do segundo volume dessa obra inacabada. Em LVME, culmina num romance plural, que inclui diversos tipos de texto não só ligados à narração, mas à descrição e à explicação, como o dicionário, a bibliografia, o índice, o catálogo, o manual. Assim, esses livros-bibliotecas operam com diversos discursos, incorporando-os, mimetizando-os ou criticando-os em sua própria escrita, de tal forma que esta característica torna-se mais importante que o próprio enredo dos livros ${ }^{157}$.

\section{Pesquisa}

$B P$ e $L V M E$ apresentam e subvertem diversos recursos de escrita ligados à prática da pesquisa: menção à consulta a livros imaginários, uso de citações sem aspas ou falsas, presença de referências bibliográficas que não podem ser consultadas e de notas de rodapé que nada explicam. Assim como os personagens de $B P$ e $L V M E$, os leitores também são conduzidos à prática da pesquisa, da consulta a outros livros ou da busca de informações no

\footnotetext{
${ }^{156}$ Expressão de Calvino (1990, p. 130) para tratar dos maiores escritores do século 20: “[...] em relação a eles falarei de um ceticismo ativo, do senso do jogo e da aposta na obstinação de estabelecer relações entre discursos, métodos e níveis.”

${ }^{157}$ Um trabalho que caminha nesta mesma direção, analisando esse fenômeno de biblioteca em Machado de Assis e Flaubert pode ser conferido no artigo "A ficcionalização do literário nas bibliotecas fantásticas de Gustave Flaubert e Machado de Assis”, de Luciana A. Schoeps (2011, p.143-167).
} 
mesmo livro, por exemplo, no Dictionnaire des idées reçues, que compõe o segundo volume, no qual encontramos os seguintes vocábulos:

$\begin{array}{ll}\text { BLONDES } & \text { Plus chaudes que les brunes (voyez brunes) } \\ & \text { Le bleu sied bien aux blondes } \\ \text { BRUNES } & \text { Plus chaudes que les blondes (voyez blondes) } \\ & \text { (BP, p. } 493 \text { e 494, respectivamente) }\end{array}$

Essa forma de pesquisa no mesmo livro também aparece em $L V M E$, como já vimos com a repetição da teoria do puzzle do preâmbulo em outro capítulo do livro. Há mais um exemplo significativo: a árvore genealógica da família Gratiolet, presente no capítulo XXI, que trata do sistema de aquecimento central do prédio e narra brevemente a história dos Gratiolet como digressão, pois eles haviam sido contra a instalação da caldeira do prédio. No capítulo LVIII, sobre Olivier Gratiolet, encontra-se a seguinte indicação:

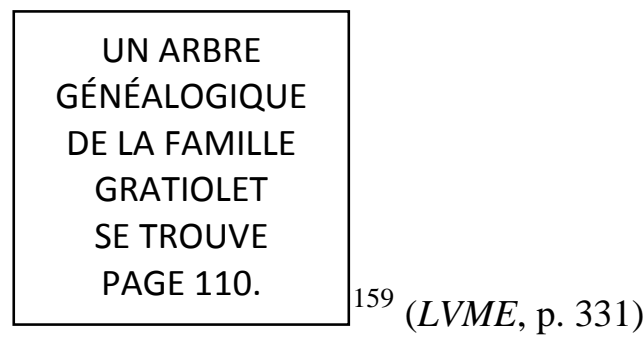

O trabalho com os saberes na ficção abre espaço para a utilização desses procedimentos formais e é uma questão que estimula muitas pesquisas sobre Flaubert e Perec. Sobre isso, Jacques Neefs afirma que "as aproximações a fazer com Perec são com certeza numerosas, profundas. É também um pouco da história do romance moderno que pode se desenhar nessas aproximações.” ${ }^{160}$ Esse tema dos saberes na ficção permanece bastante atual, sobretudo nos trabalhos sobre Flaubert, como comprova o lançamento da Revue Flaubert, em 2011, sob direção de Yvan Leclerc, inteiramente dedicada ao tema Fictions du savoir, savoirs de la fiction dans Bouvard et Pécuchet, assim como o primeiro número da Revue Arts et Savoirs, lançada pelo grupo LISAA (Littératures, Savoirs et Arts) sob coordenação de Gisèle Séginger, em 2012, dedicada ao tema Bouvard et Pécuchet: la fiction des savoirs.

\footnotetext{
158 "LOURAS. Mais quentes do que as morenas (vide morenas).

MORENAS. Mais quentes do que as louras (vide louras).”

159 “Uma árvore genealógica da família Gratiolet se encontra na página 110.”

160 “Les rapprochements à faire avec Perec sont bien sûr nombreux, profonds. C’est aussi un peu de l'histoire du roman moderne qui peut se dessiner dans ces rapprochements.”. Cf. o ensaio "Noter, classer, briser, montrer, les dossiers de Bouvard et Pécuchet". In: NEEFS; DIDIER, 1990, p. 89.
} 
A forma que Flaubert utilizou para ficcionalizar os saberes e, com isso, questionar a própria escritura romanesca instigou diversos outros escritores além de Perec, como Calvino, Joyce, Haroldo de Campos e Borges, por exemplo, a criarem “enciclopédias imaginárias na forma de ‘inventários do mundo’, galáxias, bibliotecas labirínticas, planetas fictícios e livros monstruosos” (MACIEL, 2009, p. 25) refletindo um modo de conhecimento fragmentário, multíplice, bifurcado e, por isso, cada vez mais atual.

\section{Inacabamento}

Condição essencial dos livros-bibliotecas em geral. No caso de $B P$, Flaubert morreu sem finalizar o livro; no de LVME, Perec programou a "inconclusão" do quebra-cabeça final e seu próprio livro não apresenta a saída do prédio da rua Simon-Crubellier. Os escritores desses livros que falam de livros e de personagens que lêem, pesquisam e buscam um conhecimento Total não poderiam acabar um livro e geralmente programam essa “inconclusão” para que outros possam prolongar esse livro. Isso porque a infinitude é uma característica da biblioteca que esses escritores ficcionalizam.

Para alguns, esse inacabamento provoca angústia e é prova do vazio desses livros ${ }^{161}$, para outros, a necessidade de invenção ${ }^{162}$.

\section{Amor}

Barthes afirma, em 1977, que “em todo amante há um quê de Bouvard e Pécuchet”, pois “o discursus amoroso não é dialético; gira como um calendário perpétuo, uma enciclopédia da cultura afetiva”163. Através do trabalho com o detalhe e a repetição de estruturas (no caso de Bouvard em relação aos saberes: o deslumbre, a pesquisa e o fracasso), o discurso romanesco flaubertiano adquire a forma espiral, uma vez que nunca volta ao mesmo ponto de início, mas gira como um calendário perpétuo no qual a indicação de dias e

${ }^{161}$ É o caso de Claude Burgelin quando afirma, no artigo "Perec lecteur de Flaubert”, que "o prazer lúdico que temos no jogo de todo romance corre o risco de ser contrariado por um sentimento de gratuidade. A prova do vazio, a angústia - ou o sentimento de traição - ameaçam, mesmo se aprendemos a apreciar essas histórias em que o narrativo se instala numa espiral contínua de ilusões e frustrações (Borges, Calvino, etc.).” No original: "Le plaisir ludique que nous prenons au jeu de tout roman risque d'être contrarié par ce sentiment de gratuité. L'épreuve du vide, l'angoisse - ou le sentiment de cocuage - menacent, même si nous avons apris à prendre plaisir à ces récits où le narratif s'installe dans une spirale continue de leurres et de frustrations (Borges, Calvino, etc.).” (BURGELIN, 1984, p. 162-3)

${ }^{162}$ Como naquela afirmação de BUTOR (1974, p. 199) presente na página 50 deste trabalho.

163 "Le discursus amoureux n'est pas dialectique; il tourne comme un calendrier perpétuel, une encyclopédie de la culture affective (dans l'amoureux, quelque chose de Bouvard et Pécuchet).” (BARTHES, 2003, p. 32) 
meses (os detalhes) se repetem, ao contrário dos anos, que ilustram as voltas da espiral da vida.

O que permite a Barthes declarar que o discurso amoroso tem algo dos copistas de Flaubert é a relação entre o amor e a busca infinita, elementos que formam o discurso do próprio pesquisador. Tal qual um apaixonado envenenado pelo desejo de atingir algum tipo de saber, seja de Química, Medicina, História, Línguas e Literaturas, etc., o pesquisador assume, pelo menos em algum(ns) momento(s) de seu percurso, seu objeto de pesquisa como algo fascinante e singular, talvez até difícil de classificar. Também como um apaixonado enciclopédico, surpreende-se com algumas descobertas e incontestavelmente falha (seu destino). Isso porque o objeto amado (incluindo aqui também o sujeito amado) planta no pesquisador o que chamei de semente envenenada em Flaubert. Na verdade, cada um cria uma imagem para essa relação, lembro, por exemplo, as imagens do vírus e da bulimia utilizadas por Bénabou (1990) para falar da relação entre Perec ${ }^{164}$ e seus personagens com o enciclopedismo.

Assim como a escritura de Bouvard et Pécuchet e de La Vie mode d'emploi, a escritura de uma pesquisa coloca a biblioteca em movimento, num processo de constante diálogo sobre o que é estranho e o que é amado. O suave tédio da ordem das frases nas páginas (ou dos livros na estante) de $B P$ e de $L V M E$, bem como as esboçadas aqui, é artificial, pois não garante a ordem definitiva, mas permite, na desordem, que digressões, contradições, incertezas e ideias inacabadas coexistam como na biblioteca de Babel:

Atrevo-me a insinuar esta solução do antigo problema: A Biblioteca é ilimitada e periódica. Se um eterno viajante a atravessasse em qualquer direção, comprovaria ao fim dos séculos que os mesmo volumes se repetem na mesma desordem (que, reiterada, seriam uma ordem: a Ordem). Minha solidão alegra-se com essa elegante esperança. (BORGES, 2001, p. 100)

\footnotetext{
164 Como em Flaubert, fazia parte do inventário de saberes de Perec e dos personagens de LVME: "Des références, frequentes jusqu'à l'obsession, à l'histoire de tous les temps e de tous les pays, avec une prédilection sensible pour le domaine des humanités classiques, pour la culture gréco-romaine, représentée par ses disciplines les plus traditionnelles (celles qu'on nomme sciences auxiliaires de l'histoire: archéologie, philologie, épigraphie, etc., et dans lesquelles sont supposés exceller des savants porteurs de noms germaniques). On retiendra seulement deux exemples, pris dans La Vie mode d'emploi : les recherches de Beaumont sur la cité légendaire de Lebtit; la démonstration, faite devant de $3^{\mathrm{e}}$ Congrès des Sciences historiques d'Edimbourg, à propos d'une carte ancienne de l'Amérique, et qui restitue les étapes d'une discussion scientifique particulièrement serrée.” BENABOU. Vrai et Fausse Érudition chez Perec. In: RIBIÈRE, 1990, p. 42-3.
} 


\section{Capítulo 3 - Da relação com os livros à coleção de quinquilharias: listas, descrições e outras formas de arquivamento}

\section{Espelhos de si, reflexos (das) nas obras}

Muitos escritores, críticos e outros intelectuais explicitam sua relação com os livros em entrevistas, ensaios, correspondência, anotações pessoais. Esse tipo de confissão ganha espaço na crítica porque, mesmo tendo descartado a relação causal entre os fatos da vida do escritor e a repercussão deles em suas obras, ela busca por uma construção da figura do escritor, que ainda é motivo de admiração e questionamento para muitos, sobretudo pesquisadores: Como alguém se torna escritor? Quais as características necessárias para sê-lo? O que é preciso ler? De que forma pensar sobre esse sujeito-autor ajuda a ampliar a interpretação de sua obra?

Talvez sejam esses questionamentos que impulsionem a pesquisa dos arquivos dos escritores, ou seja, a busca de tesouros perdidos que teriam a chave para as obras do escritor e que o diferenciariam das "pessoas comuns" ou ainda que ajudariam a dar forma à vida desse ser “especial”. Claro que esta é uma busca ilusória, mas o percurso e as pistas encontradas podem ser de grande valia para o estudo de suas obras.

O autor poderia ser considerado um personagem de sua própria vida? E a construção desse personagem pode ajudar a compreender alguns aspectos de sua obra? José Mindlin (2004, p.16), formador da maior biblioteca pessoal do Brasil, considerava sua relação com os livros "uma loucura mansa”, gerada pela união do "prazer intelectual da leitura” com o “prazer físico do contato com o livro”. A referência a algum tipo de loucura ligada às práticas de leitura de escritores costuma figurar no discurso de críticos e no dos próprios escritores. Algumas imagens se referem, por exemplo, à obsessão pela leitura; assim é o caso de Mindlin, que cultivava seu próprio “terreno de impressos”, ou mesmo o de Jacques Roubaud, que perambulava pelas bibliotecas públicas: BN (Biblioteca Nacional da França), Biblioteca Britânica, a do Arsenal, a da Mazarina...

A obsessão é levada ao caráter de monstruosidade nas práticas de leitura de Flaubert, que inclusive fazia cálculos da quantidade de livros lidos em determinado período. No caso de Perec, a relação com os livros é semelhante à que ele tem com as coisas, o que o faz ser muitas vezes ligado a predicativos do tipo: arquivista, colecionador de detalhes, de coisas mínimas, ou seja, da ordem da obsessão mais íntima.

Mas o que essas diferentes formas de contato com o livro têm a ver com o sujeitoautor e sua obra? A primeira resposta, e a mais banal, é lembrar que o escritor é antes de tudo 
um leitor, e que talvez, se entendêssemos alguns aspectos de suas práticas de leitura e sua relação com a biblioteca (real ou virtual), encontraríamos algumas outras pistas para caminhar por esse labirinto infinito que são as obras.

Segundo Berthomier, comentando o livro Bibliothèques d'écrivains, as anotações das obras que compõem a biblioteca de um escritor revelam "tanto uma poiética do gesto e da atividade literárias ou filosóficas quanto uma hermenêutica da recepção das obras tais como elas são lidas”165. Além disso, ela afirma que estudar a biblioteca do escritor amplia o campo interpretativo de sua obra, uma vez que o pesquisador se dedica a articular os traços recorrentes, as repetições e variações entre as obras lidas e escritas por um escritor, mobilizando o que seriam resquícios do pensamento, com a materialidade dos signos deixados na biblioteca.

Não é à toa que esse espaço real ou virtual tem se tornado objeto de interesse de muitos pesquisadores dedicados ao estudo da escrita literária, poética e crítica de um escritor, não apenas como forma, criação e composição, mas como pano de fundo, isto é, as escolhas e as mudanças ao longo da obra.

Um exemplo importante de trabalho sobre a biblioteca, no campo da crítica genética, é a pesquisa de Telê Ancona Lopez ${ }^{166}$ sobre a marginália de Mário de Andrade. Tomando como manuscrito as notas marginais e a leitura não anotada feita por Mário em seus livros, a pesquisadora analisa momentos da criação de Paulicéia desvairada. A pesquisa que compõe o projeto temático sobre a criação andradiana, coordenada por Lopez, está mais voltada para a biblioteca real do escritor, cujo acervo está disponível no Instituto de Estudos Brasileiros da Universidade de São Paulo.

Há também trabalhos dedicados a fragmentos de biblioteca em manuscritos de escritores, como a dissertação de Monica Gama sobre Guimarães Rosa. Embasada nas teorias de crítica genética e estética da recepção, um de seus objetivos foi o estudo da forma de apropriação/recriação roseana das citações presentes em Tutaméia. A pesquisadora apresenta e analisa diversas listas em que o escritor mineiro acumula falas do cotidiano e citações de livros e insere sua marca $m \%$ (meu cem por cento), indicando que aquela palavra ou frase passa a ser sua:

\footnotetext{
165 “À ce titre, les multiples investigations dont font l'objet les annotations des ouvrages que contiennent les bibliothèques participent autant d'une poiétique du geste et de l'activité littéraires ou philosophiques qu'à une herméneutique de la réception des oeuvres telles qu'elles sont lues.” (BERTHOMIER, s.d. Não paginado, grifo meu)

${ }^{166}$ Cf. um panorama geral desta pesquisa no artigo da pesquisadora "A criação literária na biblioteca do escritor”, publicado na revista Ciência e Cultura, São Paulo, v. 59, n.1. p. 33-37. jan./mar. 2007.
} 
Os vários documentos dedicados à listagem de elementos identificados pelo símbolo $m \%$ indicam que o escritor engajava-se na coleta e na produção incessante de enunciados breves, chamados aqui de "células estéticas", que depois eram transferidos para um texto em redação. Assim, ao momento de acumulação dessas pequenas partes, seguia-se a movimentação das peças. (GAMA, 2008, p. 177)

Apesar de não utilizar o termo biblioteca, Monica Gama mostra como Guimarães Rosa se apresenta como um colecionador e manipula as citações (peças) como quem movimenta os livros de uma biblioteca pessoal, edificando em forma de listas seu acervo de enunciados que aguardavam seu momento de entrar na estante da página de um romance ou de um conto, como no caso de "Desenredo" e "Sobre a escova e a dúvida", conforme a análise da pesquisadora.

A pesquisa de Gama cria uma ponte entre as bibliotecas reais e as bibliotecas virtuais dos escritores, pois não apresenta somente o modo como Guimarães Rosa se relacionava com livros disponíveis na estante de sua biblioteca pessoal ou com livros lidos no lombo de um cavalo ou na poltrona de um navio, nas muitas viagens que fez em vida. Mais que isso, ela destaca a relação do escritor com diversos discursos, impressos e orais, copiados em forma de lista, em suas anotações, suas cartas, seus cadernos e diários. Estes últimos podem ser considerados suportes privilegiados dessa biblioteca virtual, que representa a relação entre o discurso e o autor/leitor.

Segundo Louis Hay (1990, p. 15), é no diário, espaço da escrita pessoal, que se dá o trabalho do escritor de captura de fatos e palavras e que podemos "observar as relações entre lido e o escrito no momento em que se estabelecem”. Trata-se, portanto, de um suporte importante para o abrigo de leituras mise en abyme (leitura - escritura - leitura...), como no caso das infinitas notas de Flaubert nos cadernos de L'Éducation sentimentale, de Bouvard et Pécuchet, que "abrem referências e citações por campos inteiros, nos quais o autor faz grandes colheitas de prosa romanesca” (HAY, 1990, p. 14).

No entanto, a posição de Hay sobre o caráter mais “fiel” desse suporte (o diário) para tratar da relação entre o lido e o escrito parece um pouco radical, sobretudo quando ele compara essa abordagem à pesquisa de fontes (qualificada por ele de ultrapassada) ou à intertextualidade, que trabalha apenas com o que está publicado. Não colocaria o caderno numa posição superior a esses outros estudos, mas numa posição paralela que abre um novo leque de interpretações sobre as obras publicadas. Esse leque se abre, por exemplo, quando o próprio Louis Hay apresenta duas funções do caderno, a saber: o efeito de distribuição e o efeito de antecipação presentes nesse suporte de escrita. O que está escrito de forma 
condensada ou esparsa de forma casual no caderno pode ser distribuído em diferentes obras, em diferentes tempos. A intimidade desse espaço que acolhe diferentes tempos, leituras, e em que o "dono" se encontra e se perde ao mesmo tempo, pode ser associada à da biblioteca pessoal, mas numa escala micro e virtual.

Seria possível considerar as bibliotecas pessoais de escritores espelhos de suas identidades? Problematizando um pouco mais essa questão, levanto mais duas: quem explora as bibliotecas pessoais dos escritores pode ver seu próprio reflexo na leitura da biblioteca alheia? As características das bibliotecas dos escritores e suas práticas de leitura podem refletir questões para suas obras?

Para investigar essas questões, aproximarei alguns aspectos das bibliotecas pessoais de Flaubert e de Perec (incluindo aí alguns relatos de suas práticas de leitura) a alguns procedimentos de escrita ligados ao arquivamento presentes em seus romances, sobretudo em Bouvard et Pécuchet e em La Vie mode d'emploi. Este capítulo percorre, portanto, a descrição das bibliotecas reais desses escritores e de suas práticas de leitura e segue com a discussão de procedimentos descritivos empregados nos romances citados. Dessa forma, pretendo investigar mais um dos arranjos que as múltiplas peças dessa biblioteca caleidoscópica podem formar.

\section{A biblioteca espiralar e o devorador de livros}

Em 1859, Flaubert descreveu numa carta a Ernest Feydeau uma das muitas metáforas de sua relação com a escritura: "Um livro é uma coisa essencialmente orgânica, faz parte de nós mesmos.” A imagem do corpo relacionada ao livro é tão forte para o escritor que na mesma carta ele compara a publicação de um livro à "prostituição no mais alto grau”167. A aparente negatividade da exposição do livro-corpo nas prateleiras das livrarias, no entanto, caminha ao lado da valorização do trabalho da escritura (“As gotas do nosso coração podem ser vistas nos caracteres de nossa escritura”) e do ofício de escritor, que pressupõe um árduo trabalho de leitura.

\footnotetext{
167 "Un livre est une chose essentiellement organique, cela fait partie de nous-mêmes. Nous nous sommes arrachés du ventre un peu de tripes, que nous servons aux bourgeois. Les gouttes de notre coeur peuvent se voir dans les caractères de notre écriture. Mais une fois imprimé, bonsoir. Cela appartient à tout le monde! La foule nous passe sur le corps! C'est de la prostitution au plus haut degré et de la plus vile ! Mais il est reçu que c'est très beau, et que prêter son cul pour dix francs est une infamie. Ainsi soit-il!”. Flaubert à Ernest Feydeau. Croisset, 11 janvier 1859. Grifo meu.
} 


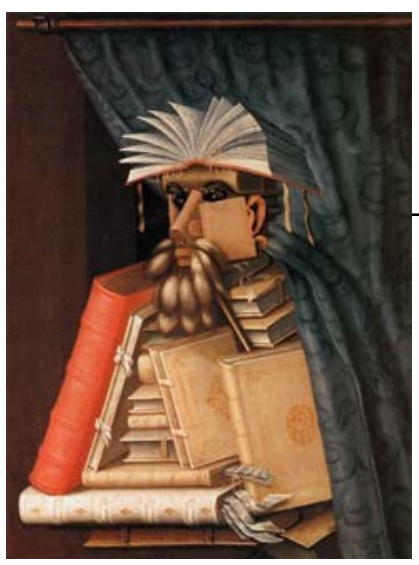

Figura 5. $O$

bibliotecário, de Arcimboldo
O homem-pluma de que fala Barthes em seu O grau zero da escritura se transforma aqui no homem-livro, semelhante à pintura do bibliotecário [Figura 5], feita por Arcimboldo em 1566, no sentido metafórico. Isso porque Flaubert está ligado a uma tradição presa à "realidade", ou seja, que não permite fabular sem se reportar a outros. Além disso, ele faz parte da geração de “escritores-pesquisadores”, dado o contexto histórico de intensa produção científica nos diversos campos do saber, bastando lembrar, por exemplo, a difusão do pensamento de Darwin a partir da metade do século XIX, os estudos sobre a teoria da evolução, a teoria celular, etc. Tudo isso implicava tanto a necessidade de documentação das obras, isto é, a construção do próprio discurso se posicionando em relação a outros, quanto o questionamento do conceito de Verdade. Além disso, esse momento também “coincide” com a popularização das bibliotecas de empréstimo na França, consequência da obrigatoriedade da alfabetização em grande escala.

Quando Flaubert nasce, em 1820, as bibliotecas ainda estão em plena formação por toda a Europa, processo que dependia da já mencionada escolarização da população (até a década de 1830, por exemplo, mais da metade era analfabeta) e de avanços técnicos na produção dos livros, que passam a ser editados em escala industrial. No entanto, o futuro escritor era privilegiado por ter acesso, em sua própria casa, em Rouen, ao acervo médico do pai e, aos poucos, pôde reunir seu acervo pessoal em Croisset, contabilizando 1689 livros em 1880, ano de sua morte. Trata-se de uma biblioteca familiar, passada como herança do Flaubert-pai ao filho Gustave e, posteriormente, à sobrinha Caroline.

Atualmente, há um grupo de pesquisadores da Universidade de Rouen que se dedica à reconstituição da biblioteca real de Flaubert. Trata-se de um projeto complementar ao livro publicado em 2001 por Yvan Leclerc, La Bibliothèque de Flaubert: inventaires et critiques, que apresenta o catálogo dos livros do escritor conservados em Canteleu, bem como inventários feitos pelo tabelião Bidauld, após a morte do escritor, e outros dois referentes a vendas em Antibes e ao Hôtel Drouot. Esse novo projeto pretende ainda abarcar sua biblioteca "virtual", 
empréstimos nas bibliotecas públicas, a Correspondência, os cadernos de anotações, os dossiês documentários, as obras... ${ }^{168}$

Enfim, um empreendimento vasto (e semelhante ao de Bouvard e Pécuchet) que demonstra a intensa "maneira de viver"169 de Flaubert ao lado dos livros. Esse trabalho já começa a ganhar forma na segunda parte do livro organizado por Leclerc que reúne apresentações do congresso internacional, realizado em 1999, de especialistas que se dedicam ao estudo da relação de Flaubert com a biblioteca nos mais diversos matizes: práticas de leitura de Flaubert, a ficcionalização do livro na obra e a presença dos livros no processo de criação do escritor.

Thierry Poyet, cujo artigo analisa os julgamentos literários de Flaubert em sua correspondência, apresenta uma imagem da biblioteca do escritor que também me fez retomar a imagem monstruosa das cabeças compostas de Arcimboldo:

A biblioteca de Flaubert é semelhante a uma caverna: ela não contém os tesouros de um Ali Baba descobridor de talentos escondidos, mas antes corpos devorados, e que ainda lá estão no entanto, de livros que vêm alimentar um ogro insaciável. ${ }^{170}$

Todos os artigos presentes em La Bibliothèque de Flaubert sustentam, cada um à sua maneira, essa imagem de Flaubert como devorador de livros e mostram de que forma essa profusão de leituras emerge em suas obras. Porém, essa imagem da insaciedade da prática de leitura também poderia ser associada a suas práticas de escrita ligadas à repetição e à descrição. Mesmo que anacronicamente, é possível aproximar a pintura do bibliotecário de

\footnotetext{
168 'Ce catalogue doit prendre place dans un projet plus ample de bibliothèque 'virtuelle', regroupant tous les livres lus, cités, annotés par Flaubert et/ou par ses personnages, dans un vaste hyper-Flaubert reliant les registres d'emprunts dans les bibliothèques publiques, la Correspondance, les carnets de notes, les dossiers documentaires des oeuvres...” Cf. esse trecho em "Notice de la bibliothèque réelle de Flaubert”. Disponível em: $<$ http://flaubert.univ-rouen.fr/bibliotheque/>. Acesso em 05 jul 2011.

${ }^{169}$ Flaubert declara, em muitas cartas a amigos que "um livro é uma maneira especial de viver”. Por exemplo, a Jules Sandeau, em agosto de 1859: "Vous me demandez si mon roman sera bientôt fini? Hélas! non; j’en suis au tiers. Un livre a toujours été pour moi une manière spéciale de vivre, un moyen de me mettre dans un certain milieu.”; a Mme. Leroyer de Chantepie, em dezembro do mesmo ano: "Si je vais si lentement, c'est qu'un livre est pour moi une manière spéciale de vivre. À propos d'un mot ou d'une idée, je fais des recherches, je me perds dans des lectures et dans des rêveries sans fin. Ainsi, cet été, j'ai lu de la médecine, et caetera.”; a Maurice Schlésinger, também em dezembro: "J'écris fort lentement, parce qu'un livre est pour moi une manière spéciale de vivre. À propos d'un mot ou d'une idée, je fais des recherches, je me livre à des divagations, j'entre dans des rêveries infinies; et puis, notre âge est si lamentable, que je me plonge avec délices dans l'antiquité." (grifos meus)

170 "La bibliothèque de Flaubert ressemble à une caverne: elle ne renferme pas les trésors d'un Ali Baba découvreur de talents cachés mais plutôt les corps dévorés et pourtant encore là de livres qui viennet de nourrir un ogre insatiable”. Cf. o artigo de Poyet“L'écriture épistolaire et les jugements littéraires chez Flaubert”. In: LECLERC, 2001, p. 339.
} 
Arcimboldo ao homem-livro Flaubert também pelo fato de ambos, cada artista à sua maneira, trabalharem com a descrição privilegiando a acumulação e a função associativa da linguagem:

[...] a mensagem é "escondida” porque o olhar é desviado do sentido do conjunto pelo sentido do detalhe; inicialmente vejo apenas frutos ou animais amontoados diante dos meus olhos; é necessário um recuo, uma mudança do nível de percepção, para que eu possa receber uma outra mensagem, um aparelho hipermetrope que me permita perceber, de repente, o sentido global, o sentido "verdadeiro". (BARTHES, 1990, p. 124)

Nesse trecho, Barthes analisa as cabeças compostas feitas pelo pintor renascentista, as quais, pela acumulação de elementos, me remetem à descrição flaubertiana, por exemplo, num dos episódios do capítulo II de Bouvard et Pécuchet, em que Pécuchet se dedica ao cultivo das flores:

\begin{abstract}
Alors Pécuchet se tourna vers les fleurs. Il écrivit à Dumouchel pour avoir des arbustes avec des graines, acheta une provision de terre de bruyère et se mit à l'oeuvre résolument.

Mais il planta des passiflores à l'ombre, des pensées au soleil, couvrit de fumier les jacinthes, arrosa les lys après leur floraison, détruisit les rhododendrons par des excès d'abattage, stimula les fuchsias avec de la colle-forte, et rôtit un grenadier, en l'exposant au feu dans la cuisine.

Aux approches du froid, il abrita les églantiers sous des dômes de papier fort enduits de chandelle; cela faisait comme des pains de sucre, tenus en l'air par des bâtons. Les tuteurs des dahlias étaient gigantesques; - et on apercevait, entre ces lignes droites les rameaux tortueux d'un sophorajaponica qui demeurait immuable, sans dépérir, ni sans pousser.

Cependant, puisque les arbres les plus rares prospèrent dans les jardins de la capitale, ils devaient réussir à Chavingolles? et Pécuchet se procura le lilas des Indes, la rose de Chine et l'Eucalyptus, alors dans la primeur de sa réputation. Toutes les expériences ratèrent. Il était chaque fois fort étonné ${ }^{171}$. (BP, p. 87, grifos meus)
\end{abstract}

Descrições desse tipo transbordam na ficção flaubertiana, sobretudo em Bouvard et Pécuchet. Nesse exemplo, temos uma acumulação problemática de flores: sabemos seus nomes, mas não nos é informada a quantidade de cada tipo (exceto as que parecem ser únicas:

\footnotetext{
171 "Então Pécuchet voltou-se para as flores. Escreveu a Dumouchel para obter mudas e sementes, comprou uma provisão de terra de urze e lançou-se resolutamente ao trabalho. Mas plantou passifloras à sombra, amoresperfeitos ao sol, cobriu os jacintos de estrume, regou os lírios após florescerem, destruiu os rododendros por excesso de podas, estimulou as fuchsias por meio de cola forte e assou uma romãzeira, expondo-a ao fogo na cozinha.

Com a aproximação do inverno, abriu as roseiras-bravas sob cúpulas de papel impermeável; pareciam pães-deaçúcar suspensos sobre bengalas. As estacas das dálias eram gigantescas, e percebia-se, entre suas linhas retas, a ramagem sinuosa de uma Sophora japonica, que permanecia imutável, sem fenecer, nem brotar.

No entanto, já que as árvores mais raras prosperam nos jardins da capital, por que não cresceriam em Chavignolles? E Pécuchet adquiriu lilases-da-Índia, rosas-da-China e eucaliptos, cuja reputação então se iniciava. Todas as experiências fracassaram. A cada vez, ficava mais estupefato.” (FLAUBERT, 2007. p.67-8)
} 
uma romãzeira e uma Sophora japonica). Também não sabemos a ordem de cultivo das flores, já que tudo é lançado no passado simples, e o fracasso da experiência está dado aos leitores com a presença do “mas” iniciando a descrição. O estranhamento gerado nessa acumulação é criado pelo dispositivo da lista, que elenca elementos do mesmo contexto (flores) fora de seu lugar ideal, como se Pécuchet tivesse cultivado as flores seguindo exatamente o oposto do que era ideal para cada espécie.

Esse pequeno e inusitado "manual de como não cultivar flores” nos faz atentar para a forma da descrição que, mais uma vez, nos remete às cabeças compostas de Arcimboldo (lembremo-nos de Primavera $^{172}$, de 1573 [Figura 6]). Umberto Eco mostra como esse artista do Renascimento transforma, de modo barroco, listas de objetos, frutas e legumes em uma forma inusitada, no caso, a face de uma pessoa célebre. Flaubert parece emprestar essa forma barroca para compor a lista da descrição do jardim (de)formado pela subversão das classificações das flores. Além disso, Joëlle Gleize (1992, p. 8) aponta que é a partir da

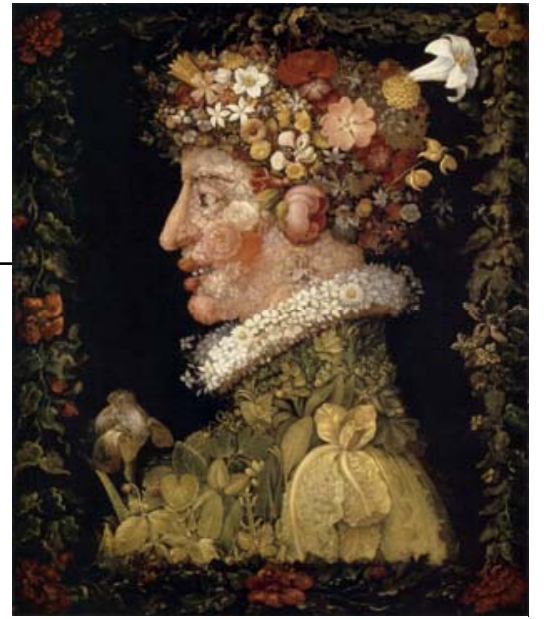

Figura 6. Primavera, de Arcimboldo estética barroca que começa essa prática de ficcionalização dos livros nos romances:

A partir de Dom Quixote, muitos romances transformaram personagens em leitores de romances. Na sequência do célebre leitor louco por romances de cavalaria, que vê e age no real apenas através do quadro de percepção e de interpretação que lhes fornecem, outros romances, no século XVIII, colocarão em cena personagens corrompidos por suas leituras romanescas. ${ }^{173}$

Voltando à relação entre Arcimboldo e Flaubert, encontramos, em ambos, um esforço de forjamento da realidade. É claro que em cada tempo essa arte de forjar adquire um sentido: no caso de Arcimboldo, um exercício de imaginação que visava à diversão de príncipes da corte alemã; no caso de Flaubert, a crítica do lugar-comum e a transgressão de um discurso representativo da realidade. Para produzir esse efeito, porém, é necessário aliar arte e

\footnotetext{
${ }^{172}$ Primavera é composta por 80 diferentes espécies de flor. É o maior número de espécies encontrado em uma só obra do pintor Arcimboldo.

173 “C'est à l'ésthétique baroque que l'on pense d'abord lorsqu'on évoque la mise en fiction de livres. Depuis Don Quichotte, de nombreux romans ont constitué en personnages des lecteurs de romans. À la suite du célèbre lecteur fou des romans de chevalerie, qui ne voit et n'agit dans le réel qu'à travers la grille de perception et d'interprétation qu'ils lui fournissent, d'autres romans, au XVIIIe siècle, ont mis en scène des personnages pervertis par leurs lectures romanesques.”
} 
conhecimento e é nesse sentido que trouxe Arcimboldo para refletir sobre as práticas de leitura e escrita de Flaubert:

Ora, o exercício de uma imaginação desse tipo [de Arcimboldo] não depende
apenas da "arte”, mas também do saber: captar metamorfoses (o que fez,
várias vezes, Leonardo da Vinci) é um ato de conhecimento; todo saber está
ligado a uma ordem classificadora, expandir ou simplesmente mudar o saber,
é experimentar, através de audaciosas operações, aquilo que subverte as
classificações a que estamos habituados: esta é a função nobre da magia,
"soma da sabedoria natural” (Picco Della Mirandola). (BARTHES, 1990, p.
134)

Nos exemplos anteriores, observamos exercícios de imaginação em torno de um trabalho artístico com a taxonomia: a ordem dos elementos e suas características na composição de Arcimboldo e na descrição flaubertiana emprestam à lista um efeito de deformação e metamorfose, pois de perto vemos flores, frutos, livros, mas se nos distanciarmos encontramos uma outra imagem: uma cabeça/um busto, na pintura de Arcimboldo; um jardim fracassado/monstruoso, na descrição de Flaubert. Neste ponto, talvez seja pertinente subverter mais uma vez as classificações a que estamos habituados e refletirmos: esse exercício de imaginação que notamos na prática de escrita flaubertiana pode ser feito com sua biblioteca real e suas práticas de leitura?

Levantei anteriormente alguns exemplos da correspondência de Flaubert, em que o escritor descreve sua relação com os livros lidos e com os livros escritos, e de como alguns críticos que estudam a biblioteca e a obra do escritor reforçam a imagem de um leitor incansável. É importante destacar que além dos volumes consultados em sua biblioteca familiar, Flaubert emprestava muitos dos livros que utilizava nas pesquisas documentais para seus romances. Em entrevista concedida à revista Le français dans tous ses états (n. 44, ano 2000), reproduzida no volume La Bibliothèque de Flaubert, Yvan Leclerc ${ }^{174}$ declara que os 1500 livros (ou mais) que Flaubert registrou ter lido para compor Bouvard et Pécuchet são emprestados. Leclerc ressalta, ainda, a heterogeneidade das leituras do escritor compostas por obras de ciências, ciências humanas e literatura. Trago essa informação sobre o empréstimo de livros para mostrar que os 1616 livros presentes no catálogo da biblioteca conservada no Hôtel de Ville de Canteleu não são suficientes para compreendermos a grande rede de relações que Flaubert promove em torno da biblioteca. Cabe destacar que mesmo esse

\footnotetext{
174 “On sait, par ses déclarations épistolaires et par ses carnets de notes, qu’il a lu environ 1500 ouvrages pour son dernier roman, Bouvard et Pécuchet. Il emprunte tous ces livres, et il ne possède à peu près que des livres de référence. [...] Flaubert lit autant d'ouvrages de sciences et de sciences humaines que de littérature, au sens de fiction.” LECLERC. Entretien sur la bibliothèque de Flaubert. In: LECLERC, 2001, p. 196.
} 
número, aparentemente exato, não pode nos servir de apoio, já que apresenta diferenças em relação ao catálogo elaborado pelo tabelião Bidauld, além de compreender livros que não pertenceram realmente ao escritor e de não contabilizar os livros que acabaram se perdendo ou que foram vendidos ao longo do itinerário da biblioteca da família Flaubert. Além disso, como venho demonstrando, essa rede de relações abarca não só a biblioteca real como seus cadernos de notas (em que anotava suas leituras, listava livros lidos e a serem lidos, e relatos de viagens), seus dossiês, sua correspondência, sua rede de contatos indicada pela quantidade de dedicatórias presentes em livros que ganhou de outros escritores, além de seus próprios livros, que novamente lançam redes de relações internas (na própria obra flaubertiana) e externas (citações, alusões, etc.). É nesse sentido que utilizo a imagem da espiral para ilustrar as bibliotecas de Flaubert, já que, como sua obra, trata-se de uma forma que não prevê a finitude, mas o prolongamento desse espaço de relações. A espiral poderia, portanto, ser utilizada como imagem da Biblioteca como tensão discursiva:

Desde as notas de leitura até o texto passado a limpo, cumpre-se um trabalho de ruminação que não visa à absorção e à assimilação, mas leva ao contrário ao estabelecimento de uma tensão discursiva da biblioteca. Em Bouvard, a biblioteca não fornece apenas o apoio documental, as precisões eruditas, o preenchimento decorativo, mas a substância mesmo da ficção, o desenrolar dos episódios, o esqueleto das frases e a matriz da enunciação. ${ }^{175}$

É por isso que é difícil falar sobre a biblioteca de Flaubert sem se reportar a uma ou outra obra do escritor. Daniel Ferrer (2001) destaca o derradeiro e inacabado romance flaubertiano como grande exemplo dessa tensão, mas ela já estava presente desde seus primeiros escritos, como em Bibliomanies, mais tarde em Salammbô, que marca o início da busca pela documentação, e principalmente em La Tentation de Saint Antoine, em que a leitura enciclopédica torna-se ainda mais ávida. Nesse sentido, Anne Herschberg-Pierrot, Claude Mouchard e Jacques Neefs (2001), no artigo “Les bibliothèques de Flaubert”, defendem a ideia da composição de uma biblioteca do século XIX na obra flaubertiana proveniente da circulação de documentos entre os romances, uma biblioteca "heteróclita,

\footnotetext{
175 “Depuis les notes de lecture jusqu'à la mise au net du texte, s'accomplit un travail de rumination qui ne vise pas à l'absorption et à l'assimilation, mais aboutit au contraire à une mise en tension discursive de la bibliothèque. Dans Bouvard, la bibliothèque ne fournit seulement l'étayage documentaire, les précisions érudites, le remplissage décoratif, mais la substance même de la fiction, le déroulement des épisodes, le squelette des phrases et la matrice de l'énonciation.” FERRER. Un imperceptible trait de gomme de tragacanthe... In: D'IORIO; FERRER, 2001, p. 23, grifo meu.
} 
abundante, parcial e esporadicamente sistemática, mas certamente excepcional em relação a outras ‘bibliotecas de escritores’ do mesmo período”"176.

Analisando os dossiês de Bouvard et Pécuchet, Jacques Neefs (1990) comenta a falta de hierarquia entre as leituras mencionadas nas listas de livros lidos por Flaubert, o que só reforça essa prática de leitura investigativa “infinita, polimorfa” relacionada “aos rumores da biblioteca, às heterogeneidades discursivas”177. No Carnet 15, caderno que inicia em julho de 1869, com o fim de L'Éducation sentimentale, encontramos a lista de livros lidos entre julho de 1872 e junho de 1874. É importante destacar que essas listas não sistematizam todas as leituras de Flaubert nesse período - as notas presentes no caderno denunciam muitas outras leituras além dos 300 lidos somados nas listas -, conforme indica a análise ${ }^{178}$ de Pierre Marc de Biasi: nas listas, são contabilizados apenas os livros integralmente lidos por Flaubert.

Os livros são como fantasmas que assombram Flaubert ao longo de toda sua vida, pois “cada leitura faz correr o risco de se afastar de si e, portanto, de se perder. Cada leitura é um perigo quando ela não enriquece [a escritura] diretamente.”179. Os personagens são geralmente porta-vozes do que Flaubert julga ser boa e má literatura ${ }^{180}$ e geralmente demonstram ser “leitores-limites” como seu criador: é o caso de Emma Bovary, assídua leitora de romances românticos, e o da dupla Bouvard e Pécuchet, copistas que se unem na empreitada de ler e absorver todos os livros (im)possíveis. Norioki Sugaya (2001) ${ }^{181}$ faz uma leitura interessante sobre a relação crítica entre as bibliotecas desses personagens. Relacionando as práticas de leitura de Emma, num tempo em que a maioria das mulheres era analfabeta, com os discursos médicos sobre histeria encontrados em manuscritos de Flaubert, os quais apresentam os 176 “On obtient ainsi une étrange bibliothèque du XIXe siècle, hétéroclite, foisonnante, partiellement et
sporadiquement systématique, mais certainement exceptionnelle par rapport aux autres 'bibliothèques
d'ecrivains' de la même période, souvent plus systématiques mais également beaucoup plus fonctionnelles et
prédéterminées, moins exotiques également. La bibliothèque de Flaubert, ouverte, imprévue, décalée souvent, est
en effet l'espace même d'une exploration par la fiction et l'écriture. Elle est la matière dont s'alimentent
l'énonciation et les épisodes, qui se diffuse dans les aventures et les phrases.” HERCHBERG-PIERROT, Anne;
MOUCHARD; NEEFS. Les bibliothèques de Flaubert. In: FERRER, 2001, p. 125, grifo meu.

177 "Les lectures ne sont pas systématiques, elles témoignent au contraire d’un désir de palper les savoirs, les discours, d'avoir d'emblée affaire aux rumeurs de la bibliothèque, aux hétérogéneités discoursives.” NEEFS, J. Noter, classer, brises, montrer, les dossiers de Bouvard et Pécuchet. In: DIDIER; NEEFS, 1990, p. 75.

178 "Sans doute Flaubert n’a-t-il en fait relevé en fin de carnet que les livres (les "volumes”) qu’il avait intégralement lus.” BIASI. Un grand carnet d'idées: le carnet 15 (1869-1974?). In: FLAUBERT, 1988, p. 463.

179 "Chaque lecture fait courrir le risque de s'écarter de soi et donc de se perdre. Chaque lecture est un danger quand elle n’enrichit pas directement. ” POYET. L'écriture épistolaire et les jugements littéraires chez Flaubert. In: LECLERC, 2001, p. 345.

${ }^{180}$ Cf. o artigo de Charles Shelly. "Pigault-Lebrun: tonner contre!” Les mauvaises lectures de Flaubert. In: Littérature, n.131, p. 18-36. 2003. Masques, intertextes.

${ }^{181}$ Cf. o artigo de Sugaya. La bibliothèque romantique d'Emma condamnée par la bibliothèque médicale de Bouvard et Pécuchet. In: LECLERC, 2001, p. 237-247. 
romances como verdadeiros vilões das mulheres, a pesquisadora mostra como Madame Bovary e Bouvard e Pécuchet podem ser lidos em relação, pois ela conclui que "apesar da cronologia das duas obras, poderíamos dizer que a história de Madame Bovary se apresenta como uma paródia dos discursos médicos sobre a histeria que contém o dossiê de Bouvard ${ }^{182}$.

A biblioteca flaubertiana pode ser considerada espiralar primeiro por seu caráter pessoal e familiar ao mesmo tempo: passa por três gerações da família Flaubert que acrescentam e suprimem volumes do acervo ao longo de suas vidas. Além disso, a espiral também está associada à prática da cópia que Flaubert fazia de trechos dos livros pesquisados, que mais tarde entrariam em sua escrita, além da repetição de referências de livros de determinado assunto em vários livros, por exemplo, notas sobre a Revolução de 1848 utilizadas na composição de L'Éducation sentimentale são novamente utilizadas em Bouvard et Pécuchet. Em terceiro lugar, mais uma volta na espiral da biblioteca flaubertiana é encontrada na ficcionalização desse espaço em suas obras, desde Bibliomanies, passando por Madame Bovary, até o caso mais perturbador de Bouvard e Pécuchet.

De 8 a 80: saímos de uma biblioteca abarrotada, com história e itinerário registrados, e cuja materialidade, pelo menos aparente, pode ser analisada ainda hoje, para visitar uma biblioteca deserta, da qual só restam resquícios de memória.

\section{Da biblioteca perecquiana e outros inventários de fantasmas}

Enquanto Flaubert possui uma vasta biblioteca real e virtual em exploração, que demonstra sua relação compulsiva com a leitura, sobretudo, em busca de uma exatidão estética em sua escritura, as bibliotecas pessoais de alguns escritores permanecem inacessíveis aos olhos ávidos de muitos pesquisadores, seja por questões burocráticas (familiares), seja por questões espaciais (institucionais ou pessoais). Este é o caso da biblioteca pessoal do escritor Georges Perec: dela só resta um catálogo ${ }^{183}$ elaborado um ano após a morte do escritor por Eric Beaumatin, escritor francês, e Catherine Binet, cineasta francesa que viveu com Perec nos últimos anos de vida dele.

Observando esse catálogo de obras que estiveram no apartamento de Perec, que somam 1855 tomos, noto primeiramente a presença de trabalhos do próprio escritor: obras

\footnotetext{
182 “Et, malgré la chronologie des deux oeuvres, on pourrait dire que l’histoire de Madame Bovary se présente comme une parodie des discours médicaux sur l'hystérie que contient le dossier de Bouvard.” SUGAYA. In: LECLERC, 2001, p. 244.

${ }^{183}$ O "Catalogue de la bibliothèque personnelle de Georges Perec" está disponível em PDF no link $<$ http://associationgeorgesperec.fr/IMG/pdf/Catalogue_BGP-email.pdf >.
} 
publicadas, traduções em outros idiomas, tapuscritos, que segundo Paulette Perec foram transferidos e organizados na Biblioteca do Arsenal, em Paris. Em segundo lugar, a quantidade de obras de ficção, sobretudo de escritores contemporâneos do século XX e membros do Oulipo (Roubaud, Queneau, Calvino...). Daniel Riou (2009, p. 461), que também analisou esse catálogo, observa que há na biblioteca real de Perec "uma literatura geral transhistórica, mas que dá mais importância ao moderno, se tomarmos modernos a partir da Renascença, como fazem os historiadores.” ${ }^{\text {184 }}$ Em terceiro lugar, deparo-me com a série de livros presenteados a Perec por amigos, como indicam as dedicatórias listadas no catálogo, sobretudo após 1978, ano da publicação de La Vie mode d'emploi, que, talvez por ter sido premiado no mesmo ano (prêmio Médicis), deu maior visibilidade ao escritor.

Apesar de o catálogo da biblioteca perecquiana trazer algumas informações importantes, como os títulos dos livros de sua biblioteca pessoal, bem como o ano da edição e até o código que indica o local que o tomo ocupava no apartamento da Rua Linné, número 13, essas informações não passam de indícios, memórias de uma biblioteca fantasma. Para tratar da relação de Perec com os livros, recorro também aos ensaios em torno dos temas “classificação/arquivamento”, que o escritor publicou em revistas nos últimos anos de vida (entre 1976 e 1982) e que foram posteriormente reunidos no volume Penser/Classer ${ }^{185}$, de 1985.

Os textos desse livro são interessantes para refletir sobre as práticas de biblioteca de Georges Perec justamente porque neles o escritor resume as principais questões teóricas e formais de toda sua obra, ou seja, discute a criação literária destacando a materialidade de suas práticas de escrita e de leitura (materialidade inexistente em sua biblioteca). Em "Notas breves sobre a arte e a maneira de organizar seus livros”, publicado pela primeira vez em 1978, Perec traz sua definição de biblioteca:

Chamo de biblioteca um conjunto de livros formado por um leitor não profissional para seu prazer e uso cotidianos. Isso exclui as coleções de bibliófilos e as encadernações a metro, e também a maioria das bibliotecas

\footnotetext{
184 "Une littérature générale transhistorique, mais qui accorde nettement plus d’importance au moderne, si on repère moderne à partir de la Renaissance, à la manière des historiens.”

${ }^{185}$ O título e o tema desse livro estimularam, mais tarde, um colóquio sobre manuscritos de escritores de diversos campos (Pascal, Leiris, Flaubert, Perec, Joyce, Guimarães Rosa, Claude Simon...) analisados em torno da questão "Pensar, classificar, escrever". Os trabalhos do colóquio foram publicados no livro Penser, classer, écrire - de Pascal à Perec, organizado por Béatrice Didier e Jacques Neefs, ensaios aos quais já recorremos nesta dissertação.
} 
especializadas (as universitárias, por exemplo) cujos problemas particulares encontram aqueles das bibliotecas públicas. ${ }^{186}$

Apesar de trazer o pronome "seus" no título, ao longo da leitura percebemos que não se trata apenas de bibliotecas particulares dos outros, o que fica claro quando ele comenta o princípio provisional que segue para ordenar sua biblioteca pessoal:

No que me diz respeito, quase três quartos dos meus livros nunca foram realmente classificados. Os que não estão organizados de uma forma definitivamente provisória estão [organizados] de uma forma provisoriamente definitiva, como no Oulipo. ${ }^{187}$

A opção por não submeter muitos de seus livros a um sistema de classificação revela não só a forma como Perec se relacionará com os demais escritores, sem submetê-los ao rigor de datas, períodos literários, gêneros, etc., mas também a quase uma relação experimental, uma desordem significativa que visa à perda do próprio leitor-Perec em outros livros, conforme ele relata: passeando os livros “de um cômodo a outro, de uma prateleira a outra, de uma pilha a outra, [e] chego a passar três horas a procurar um livro, sem encontrá-lo mas tendo às vezes a satisfação de descobrir seis ou sete outros que também podem servir”,188. Além disso, o escritor não descarta a possibilidade de as bibliotecas terem funções mais práticas, como lembrete, aparador de gatos ou lugar onde colocamos qualquer coisa.

Nesse sentido, Perec discorre sobre as duas principais questões das bibliotecas pessoais: espaço e ordem. A discussão toma a forma de um inventário de lugares, coisas e formas de classificação ligadas a bibliotecas particulares: encontramos listas de móveis que podem ocupar o mesmo espaço "sala de estar” que o móvel-biblioteca, mostrando como os livros não ocupam mais um cômodo específico da casa, mas um móvel que faz parte de um todo, ou ainda, que os livros podem se espalhar pelos cômodos da casa (entrada, sala de estar, quarto(s), banheiro) e, mais detalhadamente:

\footnotetext{
186 "J'appelle bibliothèque un ensemble de livres constitué par un lecteur non professionnel pour son plaisir et son usage quotidiens. Cela exclut les collections de bibliophiles et les reliures au mètre, mais aussi la plupart des bibliothèques spécialisées (celles des universitaires par exemple) dont les problèmes particuliers rejoignent ceux des bibliothèques publiques.” (PEREC, 1985, p. 31)

187 “En ce qui me concerne, près des trois quarts de mes livres n’ont jamais été réellement classés. Ceux qui ne sont pas rangés d'une façon définitivement provisoire le sont d'une façon provisoirement définitive, comme à l’Oulipo.” (Ibidem, p. 40)

188 ، “[...] je les promène d'une pièce à l'autre, d'une étagère à l'autre, d'une pile à l'autre, et il m’arrive de passer trois heures à chercher un livre, sans le trouver mais en ayant parfois la satisfaction d'en découvrir six ou sept autres qui font tout aussi bien l'affaire.” (Ibidem, p. 40-1)
} 
Sobre os tampos de lareiras ou radiadores (considerarão, entretanto, que o calor pode, com o tempo, revelar-se um tanto quanto nocivo),

entre duas janelas,

no vão de uma porta condenada,

nos degraus de uma escadinha de biblioteca, tornando-a inútil (muito chique, cf. Renan ${ }^{189}$ ),

sob uma janela,

em um móvel disposto de forma oblíqua e separando o cômodo em duas partes (muito chique, o efeito é ainda melhor com algumas plantas verdes). ${ }^{190}$

Esse trecho traz, além da lista de lugares que os livros podem ocupar num cômodo, algumas recomendações interessantes, como o alerta sobre o perigo de colocá-los perto de radiadores e lugares considerados "muito chiques" na época, uma escadinha ou um móvel oblíquo, lugares-comuns das bibliotecas pessoais. Outros lugares-comuns da época são mencionados na lista de "coisas que não são livros e que encontramos com frequência nas bibliotecas” (flores secas, fotografia em um porta-retrato de latão, cartões-postais, caixas, canetas, pedras, etc.). A lista de coisas que povoam os espaços das bibliotecas demonstra um procedimento de escrita que Perec justifica, em um texto crítico sobre a descrição, como um modo “de descrever os objetos que me rodeiam para não perdê-los. Porque eles se quebram, porque eu não gosto mais deles e os descarto e então, em determinado momento, tenho necessidade de fazer minhas próprias cápsulas do tempo”191.

Se encontramos nesse texto a cápsula do tempo da biblioteca perecquiana, há um outro em que Perec nos oferece a cápsula do tempo de sua escrivaninha, em "Notas concernentes aos objetos que estão sobre minha mesa de trabalho”. Estas notas, publicadas em 1976, trazem

\footnotetext{
${ }^{189}$ Ernest Renan, historiador, filósofo e escritor francês do século XIX.

190 “Sur les tablettes des cheminées ou des radiateurs (l’on considérera toutefois que la chaleur peut, à la longue, se révéler quelque peu nocive),

Entre deux fenêtres,

Dans l'embrasure d'une porte condamnée,

Sur les marches d'un escabeau de bibliothèque,

Rendant celui-ci impracticable (très chic, cf. Renan),

Sous une fenêtre,

Dans un meuble disposé en épi et séparant la pièce en deux parties (très chic, fait encore meilleur effet avec quelques plantes vertes).” (PEREC, 1985, p. 37)

191 “[...] je m'en suis servi pour faire quelque chose que je fais très régulièrement, qui est, essayer de décrire les objets qui m'entourent pour ne pas les perdre. Parce qu'il se cassent, parce que je ne les aime plus et que je les évacue et donc, il y a un certain moment, j'ai envie de faire mes propres bombes de temps.” (PEREC, 1982, p.338). O ensaio "À propos de la description” é resultado de uma apresentação num colóquio em Albé, ocorrido entre 20 e 24 de julho 1981, em que Perec apresenta seu procedimento de escrita descritivo por meio do relato de duas experiências pessoais sobre encomendas de textos dessa natureza, uma do professor Gérard Brassel, para um projeto de arquitetura e outra de um editor americano, para uma revista literária dedicada ao tema da descrição. Retomarei esse texto adiante.
} 
mais indícios das práticas materiais de escrita de Georges Perec, desde a descrição da mesa até suas práticas de limpeza e organização:

Passo muitas horas por dia sentado em minha mesa de trabalho. Talvez eu desejasse que ela fosse o mais vazia possível. Mas com mais frequência, prefiro que ela esteja abarrotada, quase até o excesso; a mesa mesmo é feita de uma placa de vidro longa de um metro e quarenta, de setenta centímetros de largura, colocada sobre cavaletes de metal. Sua estabilidade está longe de ser perfeita então não é ruim, no final das contas, que ela esteja carregada ou mesmo sobrecarregada: o peso dos objetos que ela suporta contribui para mantê-la a prumo.

Arrumo minha mesa de trabalho com bastante frequência. Isso consiste em colocar todos os objetos em outro lugar e recolocá-los no lugar um a um. Limpo a mesa de vidro com um pano (às vezes embebido em um produto especial) e faço o mesmo com cada objeto. O problema é então decidir se tal objeto deve ou não estar sobre a mesa (em seguida, será necessário encontrar um lugar para ele, mas isso geralmente não é difícil).

Esse ordenamento de meu território ocorre raramente por acaso. Ele corresponde mais frequentemente ao início ou fim de um trabalho preciso; ele intervém no coração desses dias flutuantes em que não sei bem se vou colocar a mão na massa ou se me desligo para estas únicas atividades de arrumação: organizar, classificar, colocar em ordem. É nesses instantes que sonho com um plano de trabalho virgem, intacto: cada coisa em seu lugar, nada de supérfluo, nada que ultrapasse, todos os lápis bem apontados (mas por que ter tantos lápis: numa única olhada, vejo seis!), todos os papéis empilhados ou, melhor ainda, nenhum único papel, apenas um caderno aberto sobre uma página branca (mito das mesas impecavelmente lisas de presidentes-diretores gerais: vi uma que era uma pequena fortaleza de aço, cercada de aparelhos eletrônicos ou aparelhos tais que apareciam e desapareciam quando manipulavam as teclas de uma supermesa de bordo...). Mais tarde, enquanto meu trabalho avança ou deixa de avançar, minha mesa de trabalho fica atravancada de objetos, que talvez apenas o acaso junte (secador, fita métrica), ou mesmo de necessidades efêmeras (xícara de café). ${ }^{192}$

\footnotetext{
192 “Je passe plusieurs heures par jour assis à ma table de travail. Parfois je souhaiterais qu'elle soit la plus vide possible. Mais le plus souvent, je préfère qu'elle soit encombrée, presque jusqu’à l'excès; la table elle-même est faite d'une plaque de verre longue d'un mètre quarante, large de soixante-dix centimètres, posée sur des tréteaux de métal. Sa stabilité est loin d'être parfaite et il n'est pas mauvais, en fin de compte, qu'elle soit chargée ou même surchargée: le poids des objets qu'elle supporte contribue à la maintenir d’aplomb.

Je range encore assez souvent ma table de travail. Cela consiste à poser ailleurs tous les objets et à les remettre en place un à un. J'essuie la table de verre avec un chiffon (parfois imbibé d'un produit spécial) et je fais de même avec chaque objet. Le problème est alors de décider si tel objet doit ou non être sur la table (ensuite il faudra lui trouver sa place, mais cela n’est généralement pas difficile).

Cet aménagement de mon territoire se fait rarement au hasard. Il correspond le plus souvent au début ou à la fin d'un travail précis; il intervient au coeur de ces journées flottantes où je ne sais pas très bien si je vais m'y mettre et où je me raccroche à ces seules activités de repli: ranger, classer, mettre de l'ordre. C'est dans ces instants-là que je rêve d'un plan de travail vierge, intact: chaque chose à sa place, rien de superflue, rien qui dépasse, tous les crayons bien taillés (mais pourquoi avoir plusieurs crayons: en un seul regard j'en vois six!), tous les papiers empilés ou, mieux encore, pas de papier du tout, seulement un cahier ouvert sur une page blanche (mythe des tables impeccablement lisses des présidents-directeurs généraux: j'en ai vu une qui était une petite forteresse d'acier, bourrée d'appareils électronique ou prétendus tels qui apparaissaient et disparaissaient quand on manipulait les touches d'un super-tableau de bord...).

Plus tard, quand mon travail avance ou piétine, ma table de travail s'encombre d'objets que parfois le hasard seul rassemble (sécateur, mètre pliant), ou bien des nécessité éphémères (tasse à cafè).” (PEREC, 1985, p.17-9)
} 
A precisão, das dimensões e das características dos materiais, que compõe o móvel, além da escolha do tempo presente para descrevê-lo, nos coloca diante da materialidade não só do objeto descrito como da própria escrita perecquiana. Isso porque Perec oferece características de seu próprio trabalho criativo a partir de seus objetos: as quantidades, as características, a disposição e o lugar que ocupam (se tomam conta da mesa de forma espantosa ou se são domados pelo “dono” que os coloca em outro lugar menos inoportuno) estão intimamente ligados ao momento em que o trabalho de escrita se encontra. $\mathrm{O}$ “ordenamento do território” propicia o ordenamento das ideias para o próximo trabalho, ou seja, para que ele dê início a um novo projeto, ele precisa garantir a limpeza, a ordem, a estabilização dos objetos de sua mesa, algo que é sempre provisório, já que, ao longo do trabalho, eles tornarão a ocupar aquele espaço de criação.

Na sequência, além de listar os objetos que ocupam sua mesa de trabalho, Perec comenta que iniciara um projeto sobre a história desses objetos a fim de escrever "uma certa história de seus gostos”,

Mais precisamente, será, uma vez mais, uma maneira de marcar meu espaço, uma aproximação um pouco oblíqua de minha prática cotidiana, uma forma de falar de meu trabalho, de minha história, de minhas preocupações, um esforço para compreender algo que faz parte de minha experiência, não no nível de suas reflexões longínquas, mas no cerne de sua emergência. 193

É importante destacar que tanto no texto de notas a propósito da arte de organizar livros quanto naquelas a propósito dos objetos sobre a mesa de trabalho, Perec nos coloca diante de listas e palavras, o que seria interessante para pensar sua poética "no cerne de sua emergência”, antes de desenvolvermos as reflexões mais longínquas que podem ser feitas se tomarmos os objetos, livros e lugares propriamente ditos. Ao longo de toda sua obra, Perec apresenta essa questão entre o "nome” e a “coisa”, a palavra como cápsula do tempo. Não é à toa que Les choses (1965) pode ser lido como uma "história dos anos sessenta”, uma espécie de ensaio antropológico ficcional a partir dos objetos de valor dessa época. Je me souviens (1978) é outro bom exemplo de livro em que a palavra é colocada em questão, já que a maior

\footnotetext{
193 "Plus précisément, ce sera, une fois encore, une manière de marquer mon espace, une approche un peu oblique de ma pratique quotidienne, une façon de parler de mon travail, de mon histoire, de mes préoccupations, un effort pour saisir quelque chose qui appartient à mon expérience, non pas au niveau de ses réfléxions lointaines, mais au coeur de son émergence.” (PEREC, 1985, p. 23)
} 
parte das palavras listadas sob o eixo paradigmático do sintagma "Eu me lembro...” não é conhecida hoje $\mathrm{e}^{194}$.

Essa questão da palavra e do nome na poética perecquiana pode ser lida também a partir de sua biblioteca pessoal. Presença importante em qualquer biblioteca, os dicionários também ocupavam um espaço privilegiado no acervo do escritor. Essas “ferramentas mediadoras” ${ }^{195}$ entre a cultura erudita e a cultura popular, como defende Riou (2009, p. 462), reúnem a descrição do conhecimento de diferentes áreas: idiomas, como francês, inglês e alemão (Larrousses, Roberts e Oxfords); geografia e história: por exemplo, Nouveau dictionnaire national (4 volumes, 1887), Dictionnaire de géographie ancienne et moderne (1864), Dictionnaire des châteaux de France (1978), Dictionnaire général de biographie et d'histoire (1873), Dictionnaire historique des rues de Paris (2 volumes e 1 suplemento, 1963); artes e ciência: Dictionnaire général des Lettres, des Beaux-Arts et des Sciences morales et politiques (1882), Dictionnaire universel des sciences et des arts (1854), Dictionnaire des cinéastes (do próprio escritor, publicado no volume Voeux, de 1989); matemática e física: Dictionnaire des mathématiques, organizado por François Le Lionnais, 1979, Dictionnaire de Mathématiques (1978), Dictionnaire de physique (1978); e os mais ligados à cultura popular (jogos, gírias, nomes, etc.): Dictionnaire enciplopédique d'anecdotes (2 tomos, 1929), Dictionnaire des échecs (1974), Dictionnaire des onomatopées (1828), Dictionnaire des noms propres de la Bible (1968), Le Dictionnaire Marabout des mots croisés. 3, Noms propres (1982), Le Dictionnaire des citations du monde entier (1960), Dictionnaire du français argotique et populaire (1977), Dictionnaire des mots d'esprit (1976), Dictionnaire de mots croisés (1963), entre outros.

A presença de dicionários dos mais variados (e por que não insólitos?) assuntos na biblioteca perecquiana revela o interesse do escritor pelo conhecimento catalogado e enciclopédico, o qual será utilizado na composição de seus projetos ou como matéria a ser subvertida de múltiplas formas em sua escrita ficcional e crítica. Os dicionários com certeza foram grandes aliados do escritor na composição de La disparition (1969), por exemplo, em que narrou a história do desaparecimento da letra E sem empregar sequer uma palavra ou conectivo com essa letra, empreitada quase impossível em língua francesa. Já o dicionário das

\footnotetext{
${ }^{194}$ Manlio M. Speranzini (2011. p. 103-117) faz uma leitura interessante de Je me souviens, de Georges Perec, ao lado de I remember (1975), de Joe Brainard, mostrando como o escritor norte-americano compõe as lembranças a partir de sua vida pessoal e de características da cultura e da sociedade da época por meio das restrições formal (uso da anáfora) e semântica e como o escritor francês vai retomar essas contraintes para compor uma biografia coletiva de seus contemporâneos.

195 “De la culture savant à la culture populaire si on veut, le passage de l'une à l'autre étant facilité par ces outils médiateurs que sont les dictionnaires multiples.”
} 
ruas de Paris e o de matemática podem tê-lo auxiliado na escrita de seu projeto Lieux ${ }^{196}$, em que trabalha a descrição de 12 lugares (ruas, praças, cruzamentos, passagens) marcantes em sua vida. Os de xadrez e de matemática podem ter sido consultados no projeto de La Vie mode d'emploi, em que trabalha com os procedimentos da poligrafia do cavalo, movimento dessa peça no tabuleiro de xadrez, e com a pseudoquenina de ordem 10 e o bi-quadrado latino. Suposições ou não, fato é que os verbetes, as listas, os índices, as citações, que são formas constitutivas de dicionários e enciclopédias, sempre foram a obsessão de Perec em sua prática de escrita.

Da biblioteca à escrita, a lista será utilizada por Perec como um dos procedimentos principais na criação de critérios de (des)organização dos componentes da própria escrita, exemplo das regras em forma de lista criadas para compor La Vie mode d'emploi, e da matéria de sua ficção, como a criação de personagens colecionadores ou o recurso da descrição de detalhes de espaços e objetos em seus romances.

\section{Listar, descrever, arquivar}

Os cacos da vida, colados, formam uma estranha xícara.

Sem uso,

Ela nos espia do aparador. Carlos Drummond de Andrade

Destaquei, anteriormente, a presença da lista como um recurso importante para pensar as práticas de leitura e escrita de Flaubert e de Perec. Essa antiga forma de enumeração é utilizada por ambos no sentido de transgredir a ordem hierárquica dos itens que a compõe, como vimos nos exemplos descritivos de seus textos. O trabalho (ou a "brincadeira", se quisermos ser mais lúdicos) com as listas começa desde a composição de suas obras, como vimos nos capítulos anteriores. As listas dos elementos de cada capítulo do Cahier des Charges de La Vie mode d'emploi são prova disso. Em Flaubert, procurei mostrar no primeiro capítulo desta dissertação como os saberes são listados em forma de interrogação num dos primeiros manuscritos do romance. Além disso, ao longo do livro, há uma coleção de saberes

\footnotetext{
${ }^{196}$ Trata-se de um projeto inacabado de Perec, que não foi publicado, mas que se desdobrou em outros projetos. "En 1969, j'ai choisi, dans Paris, 12 lieux (des rues, des places, des carrefours, un passage), ou bien dans lequels j'avais vécu, ou bien auquels me rattachaient des souvenirs particuliers. J'entrepris de faire, chaque mois, la description de deux de ces lieux. (...) Je recommence chaque année ces descriptions en prenant soin, grace à un algorithme auquel j’ai déjà fait allusion (bi-carré latin orthogonal, celui-ci étant d'ordre 12) premièrement, de décrire chacun de ces lieux en un mois different de l'année, deuxièmement, de ne jamais décrire le même mois la même couple de lieux.” PEREC, G. apud LEJEUNE. Les Lieux (Notes sur un travail en cours). In: HAY, 1990, p. 201-202.
} 
que estão relacionados por elementos faltantes que impulsionam novas buscas: a explosão do alambique, por exemplo, leva Pécuchet a culpar a falta de conhecimento de química dele e de seu companheiro, fazendo-os deixar a destilaria e passar ao estudo de química.

O uso da lista para estruturar a descrição revela, tanto em Flaubert quanto em Perec, a preocupação de nomear, armazenar e classificar objetos. Por estar na base da constituição do inventário e da coleção, a lista está intimamente ligada à estrutura enciclopédica.

De fato, as primeiras culturas escritas já utilizavam o recurso da lista tanto com uma função mais administrativa quanto com a finalidade de registro da civilização: desde séries de nomes de pessoas, objetos e animais até registros mais detalhados com informações sobre o clima e sistemas medicinais. Mas a lista não é só um dispositivo protocolar de arquivamento, ela produz outros efeitos quando é inserida no universo ficcional.

Talvez por isso a mobilidade que encontramos no conceito de lista. Umberto Eco, em The Infinity of lists, considera a lista algo finito, que não se pode alterar e, em dado momento, apresenta dois tipos de listas: listas práticas ou pragmáticas, aquelas que possuem função referencial: nossas listas de compras, inventários de objetos, catálogos de biblioteca, por exemplo. O outro tipo são as listas poéticas, por exemplo, o catálogo de barcos presente na Ilíada, a lista de livros imaginários em Pantagruel, ou a própria forma da poesia, entre outros. Outros críticos já veem a lista como uma forma flexível, como Maria Esther Maciel (2004) ${ }^{197}$, que destaca o jogo que a lista encena entre a continuidade, que seria a ordem prevista por sua forma, e a descontinuidade, dada a falta/quebra do fluxo discursivo que esse dispositivo de escrita impõe. Ela segue, portanto, na mesma esteira de Michel Butor (1974, p. 213 - 242), que encontra listas em estruturas frasais. Por exemplo, quando um certo número de palavras possui a mesma função na frase (uma série de adjetivos, de substantivos, de objetos diretos, etc.), ele entende que há uma parada no movimento da linha do texto e, portanto, listas. Ele relaciona a variedade das listas à variedade das frases: abertas ou fechadas, amorfas ou ordenadas, simples ou complexas.

Perec cita Butor como um dos raros escritores de sua época que praticam a "arte de enumerar” e afirma que listar não é uma prática tão simples assim:

(nada parece mais simples do que elaborar uma lista, de fato é muito mais complicado do que parece: esquecemos sempre alguma coisa, somos tentados a escrever etc., mas justamente, um inventário, é quando não escrevemos etc. A escritura contemporânea, com raras exceções (Butor),

\footnotetext{
${ }^{197}$ Cf. os ensaios “A memória das coisas: Arthur Bispo do Rosário, Jorge Luis Borges e Peter Greenaway”.
} (MACIEL, 2004. p. 13-26.); e “Do inclassificável e das classificações”. (MACIEL, 2009, p.14-30). 
esqueceu a arte de enumerar: as listas de Rabelais, a enumeração lineana de peixes em Vinte mil léguas submarinas, a enumeração de geógrafos que exploraram a Austrália em Os filhos do capitão Grant...). ${ }^{198}$

Nesse trecho, o escritor aproxima o dispositivo da lista à forma do inventário, que define como algo finito, no qual o “etc” não cabe. Também aponta o esquecimento como outra questão da lista: perder a palavra é o mesmo que perder o objeto de vista. A lista é, portanto, um dos procedimentos mais característicos da poética perecquiana (já lembrei Lieux, Les choses, Je me souviens) e La Vie mode d'emploi é talvez o maior exemplo disso, já que personagens, objetos e espaços são inventariados exaustivamente ultrapassando o limite do que caracteriza esse dispositivo, dado o trabalho sobre os mínimos detalhes, digressões e diferentes formas de enumeração, listas de listas (a começar pelo título, que impõe a forma “manual de uso”). Não é à toa que Roubaud questiona “La Vie mode d'emploi, alegoria da lista?”"199.

Ensaio de um oulipiano que emula o procedimento da lista, enumerando cada seção do texto como notas do que dizer sobre as listas em Perec, Roubaud parte da constatação de que os textos de Perec são “devorados por listas”, mostrando a cena da morte de Bartlebooth cercado de objetos, em $L V M E$, e o Index de histórias presente no final do mesmo romance. No segundo ponto, traça um breve histórico da forma poética da lista, entre eles, “a lista dos rios no poema de John Ashbery, 'Into the dusk-charged Air’ (que Georges Perec queria traduzir. A lista, e ele reconhecia explicitamente (sou testemunha), era sua ligação mais certa com a poesia),

Outro aspecto da lista mencionado por Roubaud, e que as referências a Júlio Verne trazidas por Perec no último excerto ratificam, é seu caráter didático, já que entramos em contato com a lista logo nos nossos primeiros anos de alfabetização, a começar pelas canções para fixar as vogais, o alfabeto, os números etc. Além disso, não poderíamos esquecer que o primeiro tipo de redação que conhecemos geralmente é a descrição, cuja forma mais simples é a da lista horizontal de nomes e adjetivos. É essa característica escolar da descrição

\footnotetext{
198 “(rien ne semble plus simple que de dresser une liste, en fait c'est beaucoup plus compliqué que ça n’en a l'air: on oublie toujours quelque chose, on est tenté d'écrire etc., mais justement, un inventaire, c'est quand on n'écrit pas etc. L'écriture contemporaine, à de rares exceptions (Butor), a oublié l'art d'énumérer: les listes de Rabelais, l'énumération linnéenne des poisons dans Vingt Mille Lieues sous les mers, l'énumération des géographes ayant exploré l'australie dans Les Enfants du capitaine Grant...).” (PEREC, 1985, p. 22)

199 “la Vie Mode d'Emploi, allégorie de la liste?” ROUBAUD. Notas sobre a poética das listas em Georges Perec. In: NEEFS; DIDIER, 1990, p. 203.

200 “- la liste des fleuves dans le poème de John Ashbery, 'Into the dusk-charged Air' (que Georges Perec voulait traduire. La liste, et il en convenait explicitement, (j’en témoigne) était son lien le plus certain avec la poésie)”. (Ibidem, p. 202.)
} 
perecquiana que Burgelin ${ }^{201}$ retoma para diferenciar do trabalho de descrição flaubertiana, já que entende que Perec não descreve, faz inventários a partir de formas verbais que apenas constatam a presença dos objetos ligados a adjetivos simples (cores, tamanhos, formatos), enquanto Flaubert busca encenar a fugacidade do desejo por meio da descrição:

\begin{abstract}
A descrição flaubertiana e o ato de contar perecquiano nos propõem assim duas encenações diferentes da distância - deles às coisas, deles às palavras, das coisas às palavras que dizem as coisas a nós nos textos deles, uma na oscilação entre um afastamento doloroso e uma proximidade fundível, extática e pertubadora, a outra numa distância que, para ser sempre afirmada e delicadamente mantida, é tão interrogadora quanto o tão-perto e o tãolonge flaubertiano. ${ }^{202}$
\end{abstract}

Essa forma de diferenciar os textos descritivos de Flaubert e de Perec focando a forma de encenação (Flaubert descreve, Perec faz inventários) parece valorizar a descrição como modo de representação da realidade no universo ficcional, tanto que Burgelin coloca em questão as diferentes formas de "olhar” dos dois escritores: para ele, o inventário de Perec aparentemente domestica o mundo e "a distanciação pelo humor impede toda proximidade comprometedora”, enquanto no caso de Flaubert, ao contrário, “a visão pode se tornar cegueira, [...] a contemplação do objeto o devora”203. Apesar de a descrição estar comumente relacionada a essa forma de olhar o mundo, gostaria de mudar o foco para a forma de escrever o mundo, deixando um pouco de lado essa definição mais ligada ao “objeto” da descrição para observar “como” se descreve, a partir da teoria sobre o descritivo, proposta por Philippe Hamon, que seria “o lugar de uma consciência paradigmática no enunciado”204.

Hamon busca teorizar o conceito de descritivo como procedimento retórico que demanda um savoir-faire por parte dos escritores (que ele chama de “descritor” em suas análises), por exemplo, o intenso trabalho em torno do léxico, do saber, da classificação, e

\footnotetext{
201 "Perec vient malicieusement mettre dans ce puzzle-là ses quelques pièces. La Vie mode d'emploi est emploi même pas superlative de la tautologie, la littérature mode d'emploi y est emploi simple de la narration, emploi pré-scolaire de la description, récit sans cesse refait des Habits neufs du roi.” (BURGELIN, 1984, p. 142, grifo meu)

202 "La description flaubertienne et le dénombrement perequien nous proposent ainsi deux mises en scène différentes de la distance - d'eux aux choses, d'eux aux mots, des choses aux mots qui les disent pour nous dans leurs textes, l'une dans une oscillation entre un éloignement douloureux et une proximité fusionnelle, extatique et bouleversante, l'autre dans une distance qui pour être toujours affirmée et affablement maintenue, est tout aussi interrogeante que le trop-près ou le trop-loin flaubertien.” (Ibidem, p. 147)

203 “Apparemment, l’inventaire perecquien tende de déconflictualiser et d'apprivoiser le monde. [...] La distanciation par l'humour y interdit toute proximité compromettante. [Pour Flaubert, au contraire] On sait comment la vision peut devenir chez lui aveuglement [...], la contemplation de l'objet engloutissement en lui [...].” (Ibidem, p. 148)

204 “Le descriptif, ou: le lieu d’une conscience paradigmatique dans l'énoncé.” (HAMON, 1993, p. 5)
} 
competências específicas por parte leitor (que ele chama de “descritário”), a saber, o reconhecimento (do saber que está sendo descrito) e a disposição ao aprendizado (de um novo saber). Dessa forma, ele evita o uso de termos referenciais, como descrição de espaços, de coisas, de objetos, que seriam mais subalternos ao texto narrativo.

A proposta de Hamon é muito interessante para analisar textos essencialmente descritivos, como Bouvard e Pécuchet e La Vie mode d'emploi, e mesmo outras obras de Flaubert e Perec (o próprio Hamon analisa alguns trechos de “Un coeur simple”, L'Éducation sentimentale e Madame Bovary para exemplificar sua teoria). Sem ter a intenção de dar conta de todos os elementos que permeiam a história da descrição, nem de toda a tipologia do descritivo, gostaria de me deter na questão da estética das listas nos trechos descritivos de Flaubert e Perec. Por isso destaquei a presença da lista na biblioteca e nas práticas de leitura desses dois escritores, para agora observar como a questão da lista pode se desdobrar em suas obras.

Se um dos "perigos” da descrição é dar liberdade ao leitor de pular a página, por se tratar de um trecho auxiliar e secundário em relação à história narrada, convido o leitor a se debruçar sobre alguns trechos descritivos de Flaubert e Perec, que trabalham esse procedimento textual em primeiro plano e, por isso, não descartam a atenção do leitor.

$\mathrm{O}$ trecho a seguir é do capítulo $\mathrm{V}$ de $B P$, do episódio em que os personagens desistem de estudar História, que consideram defeituosa (porque não tem a ajuda da imaginação), e partem para os romances históricos e o teatro:

Ils lurent d'abord Walter Scott.

Ce fut comme la surprise d'un monde nouveau.

Les hommes du passé qui n'étaient pour eux que des fantômes ou des noms devinrent des êtres vivants, rois, princes, sorciers, valets, gardeschasse, moines, bohémiens, marchands et soldats, qui délibèrent, combattent, voyagent, trafiquent, mangent et boivent, chantent et prient, dans la salle d'armes des châteaux, sur le banc noir des auberges, par les rues tortueuses des villes, sous l'auvent des échoppes, dans le cloître des monastères. (BP, $201)^{205}$

O mundo novo surge a partir do (re)conhecimento de homens do passado que são apresentados por meio de um resumo de suas profissões (substantivos), ações (verbos) e

205 "Primeiro leram Walter Scott.

Foi como a surpresa de um mundo novo.

Os homens do passado que, para eles não passavam de fantasmas ou nomes tornaram-se seres vivos: reis, príncipes, feiticeiros, criados, couteiros, monges, ciganos, comerciantes e soldados, que deliberam, combatem, viajam, negociam, comem e bebem, cantam e oram nas salas de armas dos castelos, nos bancos escuros dos albergues, nas ruas tortuosas das cidades, no alpendre das tabernas, no claustro dos mosteiros.” (FLAUBERT, 2007, p. 165) 
espaços (locuções adverbiais). A lista presente nesse excerto suscita diversos efeitos de leitura:

1) um efeito de resumo do que existe na poética scottiana, já que não é citado nenhum nome próprio de maior importância nesse contexto;

2) um efeito de modelo de romance histórico, característica da descrição mais próxima da retórica clássica que prevê um "topos articulado segundo as distinções de outros discursos (a lógica, a genealogia) [...]” ${ }^{206}$, um modelo teórico disposto de forma a facilitar inclusive a memorização. Assim, esse trecho apresentaria os “ingredientes” necessários para a criação de um romance (personagens, ações, cenário). O próprio narrador denuncia aqueles elementos da descrição como modelos de um gênero: "Sem conhecer os modelos, achavam as descrições parecidas, e a ilusão era completa." ${ }^{207}$ É importante lembrar que esses ingredientes serão utilizados pelos personagens de Flaubert na empreitada de escrever eles mesmos um texto literário, após o estudo de romances, peças de teatro e gramática;

3) um efeito de exposição/aquisição de conhecimento, que se liga aos dois efeitos propostos anteriormente, enfatizando os papéis de quem descreve e de quem lê a descrição. Para Hamon, aquele que descreve (o descritor) se coloca como um sábio, alguém capaz de comentar tanto as coisas do mundo quanto os textos de outros. Já o leitor da descrição (o descritário) possui uma postura retrospectiva, de quem deve reconhecer (o saber apresentado) e aprender (algo novo que lhe é proposto), diferente da postura do narratário, que deseja compreender a estrutura narrativa e saber o que vem adiante, algo que lhe será revelado no andar dos acontecimentos (postura prospectiva). Nesse sentido, os homens do passado do trecho apresentado tornam à vida porque tanto os personagens Bouvard e Pécuchet quanto nós leitores "aprendemos” quais eram suas profissões, o que faziam e onde ficavam. Ao mesmo tempo, essa "função educativa” é colocada em cheque, pois se trata apenas de um efeito de saber, informação que não é relevante posteriormente para o leitor nem para os personagens.

Exemplos como esse e o da lista de flores (do tópico 3.1.1.) transbordam na poética flaubertiana, sobretudo em Bouvard et Pécuchet, por conta de seu próprio tema. Além disso, eles se apresentam como enunciados taxonômicos, já que retomam outros sistemas de classificação (da botânica, no caso da lista de nomes de flores; da poética e da retórica, no

\footnotetext{
206 "La description, telle que la régentaient notamment les rhétoriques classiques, était toujours une sorte de check-list à parcourir, topos articulé selon les distinctions d'autres discours (la logique, la généalogie), mise en ordre d'un énoncé mais aussi sorte de 'mise en figure', ou 'de mise en espace' d'un programme d'énonciation ainsi organisé à des fins de meilleure mémorisation.” (HAMON, 1993, p. 53)

${ }^{207}$ No original, "Sans connaître les modèles, ils trouvaient ces peintures ressemblantes, et l'illusion était complète.” (BP, p. 201)
} 
caso da lista de elementos que devem compor um romance, exemplificado por Walter Scott), encenando um efeito de leitura mais próximo da função pragmática da consulta, e sendo, por isso, mais descontínuos que a narração, como vemos no exemplo a seguir:

Ils prirent en note dans le Dictionnaire des Sciences médicales, les exemples d'accouchement, de longévité, d'obésité et de constipation extraordinaires. Que n'avaient-ils connu le fameux canadien de Beaumont, le polyphages Tarare et Bijoux, la femme hydropique du département de l’Eure, le Piémontais qui allait à la garde-robe tous les vingt jours, Simorre de Mirepoix mort ossifié, et cet ancien maire d'Angoulême, dont le nez pesait trois livres. ${ }^{208}(B P$, p. 21)

Os casos clínicos consultados pelos personagens num dos livros emprestados da biblioteca do Dr. Vaucorbeil são mais uma vez resumidos primeiramente por substantivos e, mais detalhadamente, na forma de breve índice remissivo: o caso do canadense Beaumont, um caso de polifagia, de hidropsia, de obesidade, entre outros, que só conheceríamos de fato se fizéssemos uma pesquisa, já que a descrição do trecho não repete a descrição dos verbetes do dicionário que os personagens consultaram. A justaposição de palavras e de unidades frasais compõe o estilo característico do século XIX que trabalha com a enumeração de palavras (declinação lexical) e de detalhes (derivação metonímica), de acordo com a análise de Philippe Hamon de trechos dos Goncourt, Proust e Flaubert. Sobre este último, o teórico observa a tendência de um estilo caracterizado por recortes: temporal, onomástico, referencial, textual, e assim a tendência ao gesto inventariante ${ }^{209}$.

Não é à toa, portanto, que Bouvard e Pécuchet consultam um dicionário, já que este é um dos maiores exemplos de texto descritivo, por apresentar justamente uma classificação lexical em que cada elemento é explicado por meio de recursos propriamente descritivos, como a sinonímia e a antonímia, a metonímia, a parataxe (frases justapostas). É interessante observar como Flaubert subverte esse gênero de texto pronto para a consulta, com termos de diversas áreas do saber que jamais poderíamos dominar, quer porque é impossível registrar todos eles em nossa memória (a busca dos personagens e a própria leitura do romance encenam essa dificuldade), quer porque não lemos o romance para fazer pesquisas sobre

\footnotetext{
208 “Anotaram no Dicionário de Ciências médicas os exemplos de parto, longevidade, obesidade e constipação fora do comum. Como não haviam conhecido o famoso canadense de Beaumont, os polífagos Tarare e Bijoux, a mulher hidrópica do departamento de Eure, o piemontês que evacuava a cada vinte dias, Simorre de Mirepoix morta ossificada, e aquele antigo prefeito de Angoulême, cujo nariz pesava três libras.”

209 “D’où la tendance au 'style par seconde', mise en phase d'un découpage temporel, d'un découpage onomastique, d'un découpage réferentiel, et d'un découpage textuel, et la tendace à l'inventaire.” Nota sobre um trecho descritivo de L'Éducation sentimentale, de Flaubert, em HAMON, 1993, p. 59.
} 
botânica, medicina, astronomia, etc., não é essa nossa postura diante do texto (como é a dos personagens diante dos livros que leem).

Mostrei anteriormente que Perec também investe nas listas de forma exaustiva em sua escritura, mas gostaria agora de me deter em LVME como alegoria da lista, como propõe Roubaud. Nesse(s) romance(s), temos índices, receitas, bibliografias, contas de despesas de supermercado, catálogo de materiais de construção, enfim, uma infinidade de listas que compõem a vida comum. O dicionário é uma forma muito explorada por ele também, mas de uma forma diferente da adotada por Flaubert. É o que podemos notar na história do personagem Cinoc, que trabalhou com dicionários Larousse:

O nome Cinoc já apresenta um problema de ordem fonética: como ninguém sabe a pronúncia correta para seu nome, listam-se algumas opções (20 ao todo):

$\begin{array}{lllll}\text { SINOSSE } & \text { SINOK } & \text { SINOTCH } & \text { SINOCH } & \text { SINOTS } \\ \text { TSINOSSE } & \text { TSINOK } & \text { TSINOTCH } & \text { TSINOCH } & \text { TSINOTS } \\ \text { CHINOSSSE } & \text { CHINOK } & \text { CHINOTCH } & \text { CHINOCH } & \text { CHINOTS } \\ \text { TCHINOSSE } & \text { TCHINOK } & \text { TCHINOTCH } & \text { TCHINOCH } & \text { TCHINOTS } \\ \text { (LVME, p. } 346) & & & & \end{array}$

E se para conhecer o personagem precisamos desse minidicionário de pronúncia, também não ficaríamos muito surpresos em saber que os inventários de palavras representam a principal questão desse personagem, que exerceu por muitos anos a profissão de "assassino de palavras”, ou melhor, que foi o responsável por atualizar os dicionários Larousse.

\begin{abstract}
Quand il prit sa retraite, en mille neuf cent soixante-cinq, après cinquantetrois ans de scrupuleux services, il avait fait disparaître des centaines et des milliers d'outils, de techniques, de coutumes, de croyances, de dictions, de plats, de jeux, de sobriquets, de poids et de mesures; il avait rayé de la carte des dizaines d'îles, des centaines de villes et de fleuves, des milliers de chefs-lieux de canton; il avait renvoyé à leur anonymat taxinomique des centaines de sortes de vaches, des espèces d'oiseaux, d'insectes et de serpents, des poissons un peu spéciaux, des variétés de coquillages, des plantes pas tout à fait pareilles, des types particuliers de legumes et de fruits; il avait fait s'évanouir dans la nuit des temps des cohortes de géographes, de missionnaires, d'entomologistes, de Pères de l'Église, d'hommes de lettres, de généraux, de Dieux \& de Démons. ${ }^{210}$ (LVME, p. 347)
\end{abstract}

\footnotetext{
210 "Quando se aposentou, em 1965, após cinquenta e três anos de escrupulosos serviços, fizera desaparecer centenas e milhares de ferramentas, de técnicas, de costumes, de crenças, de ditos, de pratos, de jogos, de apelidos, de pesos, e medidas; riscara do mapa dezenas de ilhas, centenas de cidades e rios, milhares de capitais de cantões; devolvera ao anonimato taxonômico centenas de espécies de vacas, pássaros, insetos e serpentes, de peixes um tanto especiais, variedades de conchas, plantas não de todo semelhantes, tipos particulares de legumes e de frutos; missionários, entomologistas, de Pais da Igreja, homens de letras, generais, Deuses \& Demônios.” (PEREC, 2009, p. 347-8)
} 
Este conjunto de listas horizontais formadas, primeiramente, por estruturas frasais caracterizadas pela sinonímia em torno do núcleo “desaparecer” (“ele fizera desaparecer...”, “ele riscara do mapa”, “ele devolvera ao anonimato taxonômico”, “ele fizera dissipar na noite dos tempos”), e pela série de objetos diretos (substantivos) no plural lembra bastante o trecho das leituras de Walter Scott feitas por Bouvard e Pécuchet. No entanto, no excerto flaubertiano, a lista oferece elementos a serem agregados à busca dos personagens, tanto é que a leitura transformou os "fantasmas" dos livros em seres vivos. Nesse trecho perecquiano, ao contrário, a lista traz a questão da perda, além de uma certa nostalgia diante de uma lista exaustiva de elementos que serão esquecidos “por culpa” de Cinoc.

A questão do nome é aqui fundamental para a existência. O nome fora do dicionário transforma todos esses objetos, lugares, animais e pessoas de La Vie mode d'emploi em coisas indistintas e que não existem mais, ou pior, coisas que nunca desconfiaríamos que um dia existiram... Da mesma forma, um nome que não se sabe pronunciar, como o de $\operatorname{Cinoc}^{211}$, é uma palavra que se dissipa, desaparece.

Essa ideia atroz do desaparecimento também se liga à morte, que parece incomodar o personagem Cinoc, já que depois de aposentado, decide fazer um dicionário de palavras esquecidas, com palavras simples que ainda tinham sentido para ele, com as quais projetou criar uma história:

En dix ans il en rassembla plus de huit mille, au travers desquels vint s'inscrire une histoire aujourd'hui à peine transmissible :

RIVELETTE (s.f.)

Autre nom du myriophylle ou fenouil d'eau.

ARÉA (s.f.)

méd. anc. Alopécie, pelade, maladie qui fait tomber les poids et les cheveux. LOQUIS (s.m.)

Sorte de verroterie dont on se sert pour commencer avec les nègres sur les côtes d'Afrique. Les loquis sont des petits cylindres de verre de couleur. ${ }^{212}$ (LVME, p. 349-50)

\footnotetext{
${ }^{211}$ A variação do nome do personagem também está presente em Quel petit vélo... (1966), segundo livro de Perec. Quem é o mesmo Karamanlis, Karawo, Karawash, Karacouvé, Karaphon...?

${ }^{212}$ Em dez anos, arrecadou mais de oito mil delas, por meio das quais veio inscrever-se uma história hoje quase inapreensível:

RIVELETTE (s.f.)

Outro nome do miriófilo ou funcho-d'água.

AREA (s.f.)

Med. Ant. Alopecia, pelada, doença que faz cair os pelos e cabelos.

LOQUIS (s.m.)

Espécie de miçanga usada para comerciar com os negros nas costas da África. Os loquis são pequenos cilindros de vidro colorido.

[...]. (PEREC, 2009, p. 350)
} 
A tentativa de trazer à vida e de registrar as palavras que ainda reverberavam na memória de Cinoc, faz o dicionário de palavras esquecidas deixar de ser um inventário de palavras para se tornar uma verdadeira coleção de palavras, coleção que tenta controlar a incontrolável morte dos nomes das coisas e do personagem. Não há como não lembrar, neste ponto, do Dictionnaire des idées reçues, formulado por Flaubert para compor o segundo volume de Bouvard et Pécuchet. Diferente do dicionário de Cinoc, projeto ligado à subjetividade do personagem, o dicionário flaubertiano sobre lugares-comuns talvez não possa ser considerado uma coleção de seu criador. Por se tratar de uma montagem de citações organizadas em ordem alfabética e por seu caráter histórico e de crítica à sociedade da época, esse gesto inventariante talvez forme um arquivo. Isso porque o clichê é semelhante aos objetos (fetiches) de consumo de determinada época, que se repetem exaustivamente até uma próxima geração se tornar indiferente a eles ${ }^{213}$. Nesse sentido, no Dicionário de Flaubert o efeito é diferente do dicionário de palavras esquecidas, já que cada verbete é escolhido a partir de um recorte crítico (à sociedade, à Literatura, à religião, à política...) que causa o riso irônico, como no verbete “ANJO: funciona bem no amor e na Literatura”, em que o escritor critica a representação idealizante do amor na criação literária. Já no caso do dicionário de Cinoc, o que para o personagem é uma coleção de palavras esquecidas, para os leitores, é um dicionário de fato, já que ao final do capítulo, o leitor é colocado diante da materialidade de parte do texto: os verbetes e suas descrições dispostos nas páginas sem a presença de explicação alguma da relação das palavras com Cinoc.

Das listas de palavras passo às listas de coisas que tanto Flaubert como Perec trabalharam em suas obras. Enquanto as listas de palavras formam dicionários, enciclopédias e coleções mais próximas da atividade intelectual, as de coisas costumam formar inventários, coleções, acumulações, acervos, arquivos, museus... Mais na esfera literária do que no dia a dia, esses termos se mesclam e formam gêneros híbridos. No caso de Flaubert, essa característica do hibridismo, talvez mais perceptível no conjunto de BP (já que o próprio escritor pensou o romance como uma “enciclopédia crítica em farsa”), logo aponta para o trabalho em torno dessa forma, sobretudo com a montagem de citações. Já no caso de Perec, o hibridismo é pressuposto em seu trabalho, que praticamente nasceu experimental (pelo menos a partir de 1967, quando entrou no Oulipo).

\footnotetext{
${ }^{213}$ Nesse sentido, o primeiro romance de Perec, Les Choses (1965), que narra a história de um casal de jovens dos anos 1960 pela perspectiva dos objetos de consumo, está mais próximo (esteticamente) da frase de Flaubert, já que inventaria objetos-clichês que são o motor do desejo dos personagens.
} 
Mas não é só como estrutura que o romance-enciclopédia e o romance-manual de instruções podem ser considerados híbridos: o trabalho descritivo na composição de espaços de ambos os romances também produzem o efeito de entrelaçamento de termos ligados à organização e arquivamento da vida. Para investigar essa característica, primeiramente, entremos no apartamento do falecido personagem Winckler, de $L V M E$ :

\begin{abstract}
Maintenant, dans le petit salon, il reste ce qui reste quand il ne reste rien, des mouches par exemple, ou bien des prospectus que des étudiants ont glissés sous toutes les portes de l'immeuble et qui vantent un nouveau dentifrice ou offrent une réduction de vingt-cinq centimes à tout acheteur de trois paquets de lessive ou bien des vieux numéros du Jouet français, la revue qu'il a reçue toute sa vie et dont l'abonnement a continué à courir quelques mois après sa mort, ou bien de ces choses insignifiantes qui traînent sur les parquets ou dans des coins de placard et dont on ne sait pas comment elles sont venues là ni pourquoi elles y sont restées: trois fleurs des champs fanées, des tiges molles à l'extrémité desquelles s'étiolent des filaments qu'on dirait calcinés, une bouteille vide de coca-cola, un carton à gâteaux, ouvert, encore accompagné de sa ficelle de faux raphia et sur lequel les mots "aux délices de Louis XV, Pâtissiers-Confiseurs depuis 1742" dessinent un bel ovale entouré d'une guirlande flanquée de quatre petits amours joufflus, ou derrière la porte palière, une sorte de porte-manteau en fer forgé avec un miroir fêlé en trois portions de surfaces inégales esquissant vaguement la forme d'un Y dans l'encadrement duquel est encore glissé une carte postale représentant une jeune athlète manifestement japonaise tenant à bout de bras une torche enflammée. ${ }^{214}$ (LVME, p. 51)
\end{abstract}

A aparente imobilidade do apartamento em que não há nada transforma-se num longo parágrafo que descreve o que resta: as coisas insignificantes deixadas pelo falecido ou pelos outros. Como numa cena muda, a descrição enfoca cada detalhe dos objetos que permanecem apesar da ausência da pessoa que vivia com eles.

Forma-se aqui um inventário de quinquilharias que ultrapassam o tempo da vida do personagem Winckler e que preenchem o vazio do apartamento. Coisas que questionam a própria ideia de inventário, no sentido jurídico do termo, já que não há nada valioso, útil, que faça desse conjunto um patrimônio relevante. A forma dessa lista compõe uma acumulação de coisas cuja relação "não põe em destaque o seu valor funcional ou utilitário, a sua serventia,

\footnotetext{
214 “Agora, na pequena sala, resta o que resta quando não resta nada: moscas, por exemplo; ou prospectos que os estudantes enfiam por baixo de todas as portas do prédio, alardeando as qualidades de um novo dentifrício ou oferecendo redução de vinte e cinco cêntimos a quem comprar três pacotes de detergente; ou, ainda, velhos números do Jouet Français, a revista que recebeu durante toda a sua vida e cuja assinatura continuou a vigorar alguns meses ainda depois de sua morte; ou, então, essas coisas bem insignificantes que ficam largadas pelo chão ou pelos cantos dos armários e que não sabemos como foram ali parar ou lá permaneceram: três flores-do-campo fanadas; talos moles, na extremidade dos quais estiolam filamentos que se diriam calcinados; uma garrafa vazia de coca-cola; uma embalagem de bolo, aberta, ainda acompanhada da fita de ráfia sintética na qual as palavras "Às delícias de Luís XV, pasteleiros-confeiteiros desde 1742" desenham belo oval rodeado de guirlanda flanqueada por quatro pequenos cupidos bochechudos; [...]” (PEREC, 2009, p. 44)
} 
mas que [o artista] as estuda e as ama como o palco, como o cenário de seu destino" (BENJAMIN, 1987, p. 228). Relação que Walter Benjamin descreve para definir a figura do colecionador, em seu texto sobre a coleção de livros (biblioteca) especificamente, mas que poderia remeter aos artistas que praticaram enumerações, acumulações, colocando a matéria e objetos em destaque.

Para estudar as coisas como o cenário de seu destino, uma forma possível é aprender a "ver e ver como os míopes vêem, até o poro das coisas, porque eles enfiam o nariz em cima [delas]”215. Essa relação com coisas que Flaubert relata numa carta à Louise Colet, no momento em que ela lia e enviava seus comentários sobre L'Éducation sentimentale ao escritor, aponta para a importância do detalhe em seu trabalho descritivo, motivo de crítica de muitos teóricos, como Luckács, que defende a posição subalterna da descrição, além de A. Baron e Brunetière, críticos do século XIX que eram contra a insignificância do detalhe nos textos descritivos. Jean-Pierre Mourey, professor de estética que se dedicou à discussão sobre as práticas do detalhe, em seu Philosophies et pratiques du détail, faz uma afirmação que parece interessante para justificar essa crítica do detalhe:

O detalhe é, de fato, uma realidade imprecisa, ambígua para uma filosofia que sonha ou exige o simples, o elementar, o principiante. Não terminamos nunca quando entramos nos detalhes. Eles se empurram e não são todos da mesma importância. De uma parte detalhada de um todo (de uma paisagem, de um corpo de um rosto), podemos ainda detalhar muitas subpartes. E assim talvez ao infinito ou, ao menos, de forma indefinida. O levantamento de detalhes é apenas lista. E essa enumeração empírica é mais ou menos longa de acordo com cada um, segundo sua atenção subjetiva aos aspectos das coisas. ${ }^{216}$

Mesmo que esteja no campo da filosofia e, nesse trecho, particularmente se reportando à Estética de Hegel, que critica o valor negativo do detalhe em favor da beleza ideal (isto é, nada da crueza do mundo real no campo filosófico), Mourey levanta dois aspectos importantes do detalhe também destacados, e negativamente considerados por críticos do século XIX quando liam um Zola ou um Flaubert: a descrição pela descrição, já que os

\footnotetext{
215 "Pas si rêveur encore que l'on pense, je sais voir et voir comme voient les myopes, jusque dans les pores des choses, parce qu'ils se fourrent le nez dessus.” Flaubert à Louise Colet, 16 janvier 1852.

216 "Le détail est, en effet, une réalité floue, ambiguë pour une philosophie qui rêe ou exige le simple, l'élémentaire, le principiel. On n'en finit jamais quand on entre dans les details. Ils se bousculent et ne sont pas tous de meme importance. D'une partie détaillée d'un tout (d'un paysage, d'un corps, d'un visage), on peut encore detailer plusieurs sous-parties. Le relevé des details n'est que liste. Et cette enumeration empirique est plus ou moins longue selon chacun, selon son attention toute subjective aux aspects des choses." (MOUREY, 1996, p. 11-12)
} 
detalhes não são todos da mesma importância ${ }^{217}$; e a enumeração de detalhes considerados desimportantes, que tornam a leitura cansativa ${ }^{218}$ e ofendem a homogeneidade da narrativa. $\mathrm{O}$ romance, porém, passa a ir na contramão desse tipo de crítica e, pouco a pouco, vai acumulando cada vez mais objetos, cada vez mais elementos e detalhes do dia a dia sobem ao palco das Artes.

No campo da literatura, essa presença cada vez mais frequente do objeto é justificada pelo menos de duas formas diferentes: uma delas é a impossibilidade de narrar ${ }^{219}$ e de representar algo do mundo real, ou seja, uma irrealização do mundo ${ }^{220}$ que leva, portanto, à ideia de vazio presente também na discussão sobre a citação (não há nada a contar, só nos resta reproduzir o que já foi feito); a outra é guiada pela revisão/(re)questionamento dos "fundamentos da visão e da escritura, da representação e do jogo do significante"221, perspectiva que permite refletir sobre as práticas descritivas como questionamento da função do objeto não só na ficção como na própria vida, e sobre o trabalho de escrita em torno dos diversos modos de arquivamento e classificação que procurei mostrar nos exemplos anteriores e que gostaria de reforçar com mais dois excertos.

O primeiro deles é de Bouvard et Pécuchet, no episódio em que os personagens decidem se tornar arqueólogos e, para isso, acumulam objetos velhos em sua própria casa:

Six mois plus tard, ils étaient devenus des archéologues; et leur maison ressemblait à un musée.

Une vieille poutre de bois se dressait dans le vestibule. Les spécimens de géologie encombraient l'escalier; et une chaîne énorme s'étendait par terre tout le long du corridor.

\footnotetext{
217 “La première loi à observer, c’est de ne jamais décrire pour décrire, mais pour ajouter soit à l’intérêt du récit, soit à la puissance des poèmes. N'oubliez pas que la description est un moyen et non un but, un detail de l'ensemble et non une des parties constitutive de l'ensemble.” BARON. De la rhétorique ou de la composition oratoire et littéraire (1849) apud HAMON, 1993, p. 20.

218 “On demandera pourquoi cette continuité du détail fatigue et pourquoi cette nécessité de choisir s’impose? [...]. C'est parce que dans la vie les choses ne se passent pas comme elles devraient se passer. Nous avons besoin d'un peu d'idéal.” BRUNETIÈRE apud HAMON, 1993, p. 20.

${ }^{219}$ Genette analisa em Bouvard et Pécuchet essa impossibilidade de narrar: “Ici, donc, la littérature, après s’être émancipée de tout ce qui la nourrissait jusque-là, découvre son essence ultime, qui est de ne plus rien raconter, de ne plus rien 'représenter', mais de se livrer indéfiniment à ce mouvement circulaire qui figure à la fois son impossibilité, et l'impossibilité d’y renoncer.” GENETTE, G. Présentation. In: DEBRAY-GENETTE, R. et al. Travail de Flaubert. Paris: Seuil, 1983, p. 9.

220 A acumulação de objetos que os transformam em coisas é vista como um movimento em direção à irrealização do mundo por Claude Duchet: "Le trajet de l'objet à la chose, que l'écriture imite, conduit tragiquement à la destruction, à la déréalisation du monde.” Roman et objets: l'exemple de Mme Bovary. In: DEBRAY-GENETTE, 1983, p. 41.
}

221 "Et les différentes positions rencontrées nous conduisent, au-delà de la taxinomie, vers d'autres questions qui mettent en jeu les fondements de la vision et de l'écriture, de la représentation et du jeu du significant.” (MOUREY, 1996, p. 14) 
Ils avaient décroché la porte entre les deux chambres où ils ne couchaient pas et condamné l'entrée extérieure de la seconde, pour ne faire de ces deux pièces qu'un même appartement.

Quand on avait franchi le seuil, on se heurtait à une auge de pierre (un sarcophage gallo-romain), puis les yeux étaient frappés par de la quincaillerie.

Contre le mur en face, une bassinoire dominait deux chenets et une plaque de foyer qui représentait un moine caressant une bergère. Sur des planchettes tout autour, on voyait des flambeaux, des serrures, des boulons, des écrous. Le sol disparaissait sous des tessons de tuiles rouges. Une table au milieu exhibait les curiosités les plus rares: la carcasse d'un bonnet de Cauchoise, deux urnes d'argile, des médailles, une fiole de verre opalin. Un fauteuil en tapisserie avait sur son dossier un triangle de guipure. [...] $]^{222}$ (BP, p. 131-2)

Logo no primeiro parágrafo do capítulo, o narrador (ou descritor, se preferir) oferece a ideia condensada de um modo de arquivamento: o museu, que pode ser considerado tanto uma instituição que conserva e expõe objetos de valor histórico e/ou raros quanto, por analogia, uma coleção, que é regida por princípios espaciais e subjetivos. Ao longo da descrição, notamos que há uma problematização do espaço que os objetos ocupam, com a acumulação de objetos, geralmente no plural (amostras de geologia, archotes, fechaduras, cavilhas, parafusos, cacos, medalhas). Cabe observar que sobre tais objetos não há muitas definições quanto ao valor histórico, artístico, pessoal; além do trabalho já conhecido com os verbos no pretérito imperfeito (erguia-se, entulhavam, estendia-se, apoiava-se, desaparecia...) que prolongam a existência e a ação desses objetos. Além disso, os personagens tiveram que remover uma porta que dividia dois quartos para que os objetos pudessem ocupar os dois cômodos.

Mas o que há de especial numa velha viga de madeira, numa enorme corrente, em parafusos e cacos de telhas vermelhas? Um museu no mínimo insólito de conhecer, já que o acervo não passa de uma “coleção de cacos”, apesar de algumas “iguarias” como a carcaça de um gorro feminino de Caux, uma placa de lareira com a imagem de um monge e de uma pastora e, se seguirmos o trecho descritivo no livro, dois cocos que Pécuchet conservava

\footnotetext{
222 "Seis meses depois, haviam se tornado arqueólogos; e a casa parecia um museu.

Uma velha viga de madeira erguia-se no vestíbulo. Amostras de geologia entulhavam a escadaria e uma enorme corrente estendia-se no chão, ao longo de todo o corredor.

Haviam arrancado a porta de comunicação entre os dois quartos onde não dormiam e fechado o acesso à entrada externa do segundo quarto, para fazer dos dois cômodos um único quarto.

Ao transpor a entrada, tropeçava-se em uma gamela de pedra (um sarcófago galo-romano); em seguida os olhos eram atingidos pelas quinquilharias.

Na parede da frente, um caldeirão apoiava-se em dois cães de chaminé e uma placa de lareira, representando um monge a acariciar uma pastora. Sobre pequenas prateleiras penduradas ao redor, viam-se archotes, fechaduras, cavilhas, parafusos. O assoalho desaparecia sob os cacos de telhas vermelhas. Uma mesa no centro exibia as curiosidades mais raras: a carcaça de um gorro de mulher de Caux, duas urnas de argila, medalhas, um frasco de vidro opalino. Uma poltrona em tapeçaria apresentava, no espaldar, um triângulo de guipira.”
} 
desde a juventude e, o objeto mais belo de todos para Pécuchet, uma estátua de São Pedro. "Pécuchet, de sua cama, notava tudo aquilo enfileirado - e às vezes ia até o quarto de Bouvard para estender a perspectiva”223.

A coleção de Bouvard e Pécuchet assemelha-se aqui, mais uma vez, ao exercício enciclopédico, já que não está ligada somente à subjetividade, mas à atividade intelectual: as quinquilharias ofereceriam materialmente o conhecimento da arqueologia que eles desejavam naquele episódio. Ela pode lembrar os armários de curiosidade ${ }^{224}$ do Renascimento, formados por objetos heteróclitos e insólitos (medalhas, animais empalhados, conchas, borboletas e outros insetos secos...) que são, talvez, precursores dos museus modernos.

Entremos agora na loja de antiguidades de Mme. Marcia, de LVME:

L'arrière-boutique du magasin d'antiquités de Madame Marcia.

Madame Marcia habite, avec son mari et son fils, un appartement de trois pièces au rez-de-chaussée droite. Son magasin est au rez-de-chaussée également, mais à gauche, entre la loge de la concierge et l'entrée de service.

Madame Marcia n'a jamais établi de distinction réelle entre les meubles qu'elle vend et ceux dans lesquels elle vit, ce qui fait qu'une part importante de ses activités consiste à transporter meubles, lustres, lampes, pièces de vaisselle et objets divers entre son appartement, son magasin, son arrière-boutique et sa cave. Ces échanges, qui sont suscités aussi bien par des occasions propices de vente ou d'achat (il s'agit alors de faire de la place) que par des inspirations subites, des lubies, des caprices ou des dégoûts, ne se font pas au hasard, et n'épuisent pas les douze possibilités de permutations qui pourraient se faire entre ces quatre lieux et que la figure 1 met bien en évidence; ils obéissent strictement au schéma de la figure 2: quand Madame Marcia achète quelque chose, elle le met chez elle, dans son appartement, ou dans sa cave; de là, ledit objet peut passer dans l'arrièreboutique, et de l'arrière-boutique dans le magasin; du magasin enfin il peut revenir - ou parvenir, s'il venait de la cave - dans l'appartement. Cela qui est exclu, c'est qu'un objet revienne dans la cave, ou arrive au magasin sans être passé par l'arrière-boutique, ou repasse du magasin dans l'arrièreboutique, ou de l'arrière-boutique dans l'appartement, ou enfin passe directement de la cave à l'appartement.

\footnotetext{
223 "Pécuchet, de son lit, apercevait tout cela en enfilade - et parfois même il allait jusque dans la chambre de Bouvard, pour allonger la perspective.” (BP, P. 165)

${ }^{224}$ Ainda sobre esses armários de curiosidade: "Tendo se associado, nos séculos anteriores, ao exercício enciclopédico, vide o 'surto colecionador' renascentista que resultou na proliferação dos heteróclitos 'armários de curiosidade', ele esteve ainda atrelado, enquanto repositório de raridade e objetos de arte, à ideia de prestígio social e econômico, o que propiciou, inclusive, o surgimento dos museus no mundo moderno." (MACIEL, 2009, p. 27)
} 


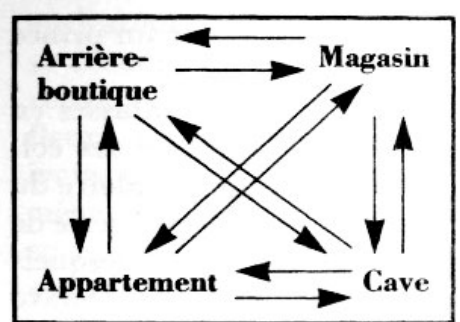

Figure 1

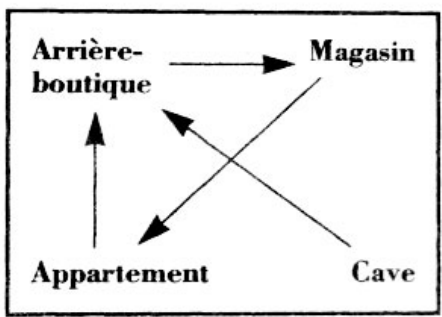

Figure 2

L'arrière-boutique est une pièce étroite et sombre, au sol recouvert de linoléum, encombrée, à la limite de l'inextricable, d'objets de toutes dimensions. Le fouillis est tel qu'on ne saurait dresser un inventaire exhaustif de ce qu'elle contient et qu'il faut se contenter de décrire ce qui émerge un peu plus précisément de cet amoncellement hétéroclite.

Contre le mur de gauche, à côté de la porte faisant communiquer l'arrièreboutique et le magasin, porte dont le battant ménage le seul espace à peu près libre de la pièce, se trouve un grand bureau Luis XVI à cylindre, de facture plutôt épaisse ; le cylindre est relevé laissant voir un plan de travail gainé de cuir vert sur lequel est posé, en partie déroulé, un emaki (rouleau peint) représentant une scène célèbre de la littérature japonaise [...].

Plus loin, le long du mur, six chaises en bois peint, couleur vert béladon, sur lesquelles sont posés des rouleaux de toiles de Jouy. ${ }^{225}$ (LVME, p. 136-137, grifo meu)

Este capítulo do romance perecquiano é totalmente descritivo, por isso foi preciso trazer um longo trecho que pudesse de alguma forma resumi-lo. O espaço aqui é mais uma

\footnotetext{
225 "A sala dos fundos da casa de antiguidades da senhora Marcia.

A senhora Marcia mora, com o marido e o filho, num apartamento de três peças do andar térreo à direita. A loja também está situada no andar térreo, mas à esquerda, entre o aposento da porteira e a entrada de serviço. A senhora Marcia nunca chegou a estabelecer diferença real entre os móveis que vende e aqueles que usa, o que faz com que uma parte importante de suas atividades consista em transportar móveis, lustres, abajures, peças de louça e objetos vários entre seu apartamento, a loja, a sala dos fundos desta e o subsolo. Essas trocas, suscitadas tanto por ocasiões propícias de vendas ou de aquisições (trata-se então de fazer praça) quanto por inspirações súbitas, manias extravagantes, caprichos ou desgostos, não se produzem por acaso nem esgotam as doze possibilidades de permutações que se poderiam fazer entre esses quatro lugares que a figura 1 demonstra com clareza; obedecem com rigor ao esquema da figura 2: quando a senhora Marcia compra alguma coisa, guarda-a em sua casa, no apartamento ou no depósito do subsolo; dali, o objeto pode passar à sala dos fundos da loja e, desta, à loja propriamente dita; da loja pode, por fim, retornar - ou chegar, se provinha do depósito - ao apartamento. O que está fora de questão é um objeto voltar ao depósito ou chegar à loja sem ter passado antes pela sala dos fundos, ou passar da loja para a sala dos fundos, ou desta para o apartamento, ou, enfim, passar direto do depósito para o apartamento. [Diagramas indicados como Figura 1 e Figura 2] A sala dos fundos da loja é uma peça estreita e sombria, de piso recoberto de linóleo, atulhada, até os limites do inextricável, com objetos de todas as dimensões. A barafunda é tal que seria impossível levantar um inventário exaustivo do que aí se contém, e teríamos de nos contentar com a descrição do que emerge um pouco mais claramente desse amontoado heteróclito.

Contra a parede da esquerda, ao lado da porta que serve de comunicação entre os fundos da loja e a loja, porta cujo batente encerra o único espaço mais ou menos livre de toda a peça, encontra-se uma escrivaninha Luís XVII com porta de enrolar, de feitura menos esmerada; a esteira está enrolada, deixando ver o tampo de escrever recoberto de couro verde, sobre o qual está pousado, em parte desdobrado, um emaki (rolo pintado) que representa uma cena célebre da literatura japonesa [...]. Mais à frente, encostadas à parede, seis cadeiras de madeira pintada, cor verde-chorão, sobre as quais estão colocados rolos de tecidos de cretone para forração de interiores". (PEREC, 2009, p.134.)
} 
vez o princípio organizador do capítulo: Mme Marcia não sabe a diferença entre seus objetos e os objetos da loja, prontos para serem de outros, fato que a faz transitá-los pelos cômodos de forma esquemática, como mostram os diagramas presentes nas figuras 1 e 2. Enquanto no trecho flaubertiano foi possível traçar algumas aproximações do surto cumulativo dos personagens com o gesto colecionador e a atividade intelectual, o capítulo de Mme. Marcia permite observar algum modo de arquivamento?

Ele poderia ser aproximado da lista, que é o princípio constitutivo de todas as outras formas de catalogação, pois há nesse capítulo uma lista de objetos (móveis, lustres, abajures, peças de louças, uma escrivaninha Luís XVII com porta de enrolar, um emaki [rolo pintado], seis cadeiras de madeira pintada, rolos de tecidos de cretone), e também uma outra lista de procedimentos para o movimento dessas peças pelos cômodos: sala dos fundos da loja, loja, apartamento e depósito, o que torna essa segunda lista mais próxima do manual de instruções $^{226}$ (um manual sobre os mesmos movimentos que repetimos em nossas formas de organização do espaço, dos livros, da vida, que indica inclusive o que está fora de cogitação, o que subverteria a “ordem normal das coisas”).

A partir da descrição de cada um dos cômodos, talvez pudesse trazer o conceito de inventário para justificar o levantamento detalhado dos objetos que ocupam (temporariamente) cada espaço, mas o próprio narrador atenta para a inadequação desse termo por conta da desordem geral que rege aqueles lugares (“A barafunda é tal que seria impossível levantar um inventário exaustivo do que aí se contém, e teríamos de nos contentar com a descrição do que emerge um pouco mais claramente desse amontoado heteróclito”).

Perec brinca, portanto, com a ordem taxonômica, já que nenhum dos modos de arquivamento e, ao mesmo tempo, todos eles servem para justificar seu trabalho descritivo. Se seguíssemos até o final do capítulo XXIV, notaríamos uma biblioteca ("in-fólios vermelhoescuros; coleções encadernadas da Semaine Théâtrale; um belo exemplar do Dictionnaire de Trévoux em dois volumes, [...]”), um catálogo de pequenos objetos, ou melhor, de quinquilharias (“conjuntos de toalete, caixinhas de pílulas, estojos de pintura, bandejas de metal prateado, castiçais, [...]”), como aquelas que ocupavam a mesa de trabalho do escritor; e

\footnotetext{
${ }^{226}$ Os diagramas lembram também o organograma trabalhado por Perec em L'art et la manière d'aborder son chef de service pour lui demander une augmentation, em que são elencadas várias possibilidades de acontecimentos e ações que podem ocorrer quando se quer pedir um aumento de salário ao chefe, além de um texto descritivo sem pontuação que traça todos os caminhos possíveis do organograma. Veja um trecho lido por Valérie Bonneton no teatro Rond-Point no natal de 2011. Disponível em: $<$ http://www.youtube.com/watch?v=r7PKC8xTY-8\&noredirect=1>. Acesso em 25 jan. 2012.
} 
finalmente uma coleção, ou museu, de quadros, como a que vemos em Un cabinet d'amateur ${ }^{227}$.

A quantidade de detalhes presente nesse trecho descritivo demonstra uma tentativa de esgotamento característica da poética perecquiana. O prazer em acumular pequenos detalhes revela um escritor que deseja arquivar tudo que está a sua volta, engarrafar detalhes e criar verdadeiras cápsulas do tempo, que são

objetos que enterramos muito, muito profundamente sob a terra para que, daqui a milhões de anos os astronautas, os astronautas não, os extraterrestres os descubram, e percebam que amávamos Elvis Presley, coca-cola, e Jane Mansfield. ${ }^{228}$ (PEREC, 1982, p. 338)

O prazer de colecionar esses pequenos objetos em La Vie mode d'emploi não é exatamente o mesmo da pesquisa compulsiva de Bouvard et Pécuchet, mas ambos os gestos possuem elementos em comum: o prazer do reencontro de objetos, de palavras, de ideias, talvez até o prazer do esquecimento, mas com certeza o prazer da perda de si mesmo nos detalhes desses livros-bibliotecas que mesclam diversos modos de arquivamento “de caráter móvel e intercambiável, [que] indiciam a diversidade com que buscamos organizar a ordem desordenada da vida.” (MACIEL, 2009, p. 30)

\footnotetext{
${ }^{227}$ Un Cabinet d'amateur - l'histoire d'un tableau foi publicado um ano depois de La Vie mode d' emploi, em 1979, e conta a história de Humbert Raffke. Começando sua coleção particular de pinturas, o personagem faz uma encomenda ao pintor Heinrich Kürz. O resultado é uma tela com um detalhe que perturba e que possui uma função fundamental na narrativa. Essa obra foi traduzida em português em 2005, pela Cosac Naify, com o título A coleção particular - história de um quadro.

228 “[...] ce sont ces objets que l'on enfouit très, très profondément sous terre pour que dans des millions d'années des cosmonauts, non pas des cosmonauts, les extra-terrestres les découvrent, et s'aperçoivent qu'on aimait Elvis Presley, le coca-cola, et Jane Mansfield.”
} 


\section{Mais uma volta na espiral}

Quantas coisas não retornam à memória uma vez nos tenhamos aproximado das montanhas de caixas para delas extrair os livros para a luz do dia, ou melhor, da noite. Nada poderia realçar mais a operação de desempacotar do que a dificuldade de concluí-la.

Walter Benjamin

Só nos resta inventar para cada um de nós uma biblioteca ideal de nossos clássicos; e diria que ela deveria incluir uma metade de livros que já lemos e que contaram para nós, e outra de livros que pretendemos ler e pressupomos possam vir a contar. Separando uma seção a ser preenchida pelas surpresas, as descobertas ocasionais.

Ítalo Calvino

No início da dissertação, mencionei a angústia diante da multiplicidade de livros que mereciam subir à estante da página. Esse sentimento era agravado, em primeiro lugar, pelo fato ter escolhido livros que falam de livros, que ficcionalizam o espaço e a dinâmica das bibliotecas a partir da citação ou da inclusão do discurso de outros escritores e de outros saberes, além da presença de personagens leitores. Em segundo lugar, a escolha da forma de ler esses livros-bibliotecas a partir do tema da biblioteca implicava em um espraiamento dessas obras e em conduzir a leitura relacionando os romances $L V M E$ e $B P$ a outros dos mesmos e de outros escritores. Essa escolha parte, sobretudo, de um convite das próprias obras lidas, já que a biblioteca não é um tema exclusivo de $L V M E$ e $B P$ e do meu modo de ler, mas refletem a dinâmica dos projetos estéticos desses escritores.

Nesse sentido, o tema da biblioteca formou, em três capítulos, uma rede de caminhos entrecruzados entre a biblioteca virtual, a biblioteca imaginária e a biblioteca real. Isso porque, como procurei mostrar no primeiro capítulo "Assombros da biblioteca”, esse tema é suscitado tanto pelas práticas de leitura quanto de escrita de Flaubert, que possui uma certa compulsão pela aquisição de conhecimento a partir dos livros. Em sua correspondência, o escritor relata a loucura de escrever um romance como $B P$, já que assim como os personagens, leu uma extensa bibliografia sobre diversas áreas do conhecimento para trabalhar com os discursos alheios e estabelecer uma crítica do cientificismo e das ideias prontas que circulavam em sua época. Já Perec programou diversas citações e alusões a outros livros em seus romances, além de ter o que Bénabou (1990) chamou de "sonho enciclopédico”, perpetuando a necessidade de estudo e pesquisa para compor e fazer experimentações de linguagem em seus escritos.

Também procurei tratar a biblioteca como uma metáfora de leitura, já que, como leitora, estou frequentando esses livros-bibliotecas, ou seja, esses livros que foram escritos 
com base na reflexão sobre outros livros, sobre o discurso alheio. Nesse trajeto, recorri à biblioteca fantástica de Foucault para justificar esse modo de ler livros em relação que não reconhece um texto como base para outro, mas privilegia a reescrita, a repetição, o prolongamento desses livros dentro do sistema literário. Por esse motivo, ainda no primeiro capítulo, trouxe a discussão sobre os conceitos já estabelecidos pela crítica para relacionar textos, como intertextualidade e reescritura, não só para mostrar suas características e entraves, mas porque foi a partir deles que compreendi o fenômeno de biblioteca como modo de ler em relação.

Esse conceito de biblioteca, apesar de fluido e ambíguo, apresentou-se como um modo mais proveitoso para abordar as obras desses escritores de forma mais abrangente e, ao mesmo tempo, mais subjetiva. Isso porque esse tema me permitiu não só falar do meu papel como leitora que estabelece a relação entre os livros, mas também de práticas de leitura dos escritores, ao resgatar relatos de suas bibliotecas virtuais e, com isso, tratar de suas práticas de escrita. É por esse motivo que, apesar de tratar da biblioteca inicialmente como um fenômeno de leitura, não recorro a teóricos da leitura, como Jauss, Iser, etc. Esse aprofundamento talvez seja um dos caminhos que esta pesquisa pode percorrer no futuro.

O segundo desdobramento do tema da biblioteca está ligado à imaginação. No capítulo “Os livros-bibliotecas de Flaubert e Perec”, procurei mostrar a ficcionalização da biblioteca nos romances $B P$ e $L V M E$, por meio da caracterização dos personagens (autodidatas, pesquisadores, colecionadores); da hibridização de gêneros, impressa em ambos os romances; e da incorporação na ficção de saberes que questionam o estatuto de Verdade, da representação da realidade e da composição do discurso romanesco e ficcional. Como forma de refletir sobre a própria escrita da pesquisa do tema da biblioteca em Flaubert e em Perec, procurei mimetizar alguns recursos dos escritores, utilizando, por exemplo, uma citação do conto “Jardim de veredas que se bifurcam”, de Jorge Luis Borges, no tópico em que analiso um capítulo de BP; uma citação do ensaio “Crítica e invenção”, de Michel Butor, na parte da análise sobre LVME; e, finalmente, na tentativa de relembrar o Dictionnaire des idées reçues (Dicionário de ideias aceitas), de Flaubert, compus a parte final do capítulo com a síntese dos "lugares-comuns dos livros-bibliotecas", isto é, com características que são comumente encontradas em livros que ficcionalizam o fenômeno de biblioteca.

Já no terceiro capítulo, “Da relação com os livros à coleção de quinquilharias”, refleti sobre a formação de bibliotecas reais dos escritores e sobre a questão do “viver entre livros”. O propósito era relacionar as formas de arquivamento reais com procedimentos de escritas ficcionais como o trabalho com listas e descrições que revelam o gesto colecionador e 
inventariante dos personagens e dos escritores e nos permitem pensar sobre nossa própria forma de nos relacionar com os objetos e as coisas.

Nesta pesquisa, não procurei investigar os acervos dos escritores, nem me deter profundamente em suas bibliotecas virtuais e pessoais, o que talvez me permitisse sustentar uma leitura genética de suas obras - outra possibilidade para a continuidade deste trabalho no futuro. Apesar de ter algumas leituras dessa área em meus bastidores e de dialogar com questões que tocam as margens da crítica genética, como fiz ao observar os vestígios das práticas de leitura e escrita dos escritores em suas correspondências, no caso de Flaubert ${ }^{229}$, e em entrevistas e no Cahier des Charges, no caso de Perec ${ }^{230}$, e nos catálogos das bibliotecas pessoais de ambos os escritores ${ }^{231}$, não aprofundei, nem discuti questões específicas dessa metodologia de pesquisa, pois optei por um recorte temático que me permitisse ensaiar um movimento entre: $L V M E$ e $B P$, as práticas de escrita e leitura de Flaubert e Perec, outras obras desses e de outros artistas cujos signos também me seduziram. Essa característica me aproximou mais de uma prática de leitura temática do que genética, pois, de acordo com Starobinski (2001b, p. 39), a leitura de temas consiste em objetivar o modo como as obras seduzem o leitor:

Será necessário para isso não renegar minha “impressão”, mas colocá-la entre parênteses, e tratar decididamente como objeto esses sistema de signos cuja potência experimentei. Esses signos me seduziram, eles são portadores do movimento que se realizou em mim. Longe de recusar sua sedução, ou o choque sofrido, longe de esquecer o primeiro encontro, procurei satisfazer a esse sentimento, iluminá-lo em meu próprio pensamento, e não poderia fazer isso com qualquer chance de sucesso a menos que ligasse estreitamente $o$ primeiro atrativo (o que tomei por sentido) a seu substrato verbal, à sua base formal. ${ }^{232}$

\footnotetext{
${ }^{229}$ A correspondência de Flaubert foi utilizada ao longo de toda a dissertação para discutir as práticas de leitura e escrita do escritor. No entanto, no tópico 1.3., do Capítulo 1, apresentei questões mais específicas sobre o processo de composição de $B P$, inclusive, trouxe um trecho de um roteiro de Flaubert para comentar a configuração enciclopédica tabular desse romance.

${ }^{230}$ Trechos de entrevistas e conferências de Perec foram trazidos à discussão ao longo de todo este trabalho, porém, no tópico 1.2., do Capítulo 1, concentrei-me na apresentação dos vestígios do processo de composição de LVME a partir do Cahier des charges de La Vie mode d'emploi (1993), conjunto de manuscritos facsimilados de Georges Perec da fase preparatória do romance.

${ }^{231}$ Reflexões a partir do catálogo das bibliotecas pessoais de Flaubert e Perec podem ser conferidas no Capítulo 3 desta dissertação, especificamente nos tópicos 3.1.1. e 3.1.2.

232 'Il faudra pour cela non pas renier mon 'impression', mais la mettre entre parenthèses, et traiter résolument en objet ce système de signes dont j'ai éprouvé la puissance. Ces signes m’ont séduit, ils sont porteurs du mouvement qui s'est réalisé en moi. Loin de récuser leur séduction, ou le choc subi, loin d’oublier la première rencontre, je cherche à leur faire droit, à les mettre en lumière dans ma propre pensée, et je ne puis le faire avec quelque chance de réussite qu'à la condition de lier étroitement le premier attrait (ce que j'ai pris pour le sens) à son substrat verbal, à sa source formelle.”
} 
Ao propor uma releitura de Flaubert e Perec a partir do desdobramento do tema da biblioteca, desejei, de alguma forma, imprimir também o movimento de minha pequena biblioteca pessoal, seguindo a sugestão da epígrafe de Calvino. Para corroborar essa proposta, incorporei à discussão a Biblioteca Imaginária de João Alexandre Barbosa (1996), que relê Eça de Queirós, Machado de Assis, Paul Valéry, entre outros, no final do último século, para criar sua "biblioteca imaginária, metáfora para o cânone daquele tempo que virá" (BARBOSA, 1996, p. 58). Outra biblioteca, desta vez um pouco menos acadêmica e mais inventiva, que está presente neste trabalho é a de Alberto Manguel (2006). A biblioteca à noite apresenta ensaios sobre a biblioteca, que foram reunidos não com o intuito de contar a história das bibliotecas, mas de relatar seu espanto pelas múltiplas formas da biblioteca na cultura humana a partir de sua experiência pessoal de colecionador, de alguém que ama viver entre livros. Ao lado desses dois exemplos, outros escritores também desempacotaram suas bibliotecas ideais em seus textos, revelando seu caráter colecionador. De acordo com Benjamin (1987, p. 228), a existência do colecionador está sujeita “a uma relação com as coisas que não põe em destaque o seu valor funcional ou utilitário, a sua serventia, mas que as estuda e as ama como o palco, como o cenário de seu destino”, como já lembrei no Capítulo 3. Dessa forma, procurei conduzir o tema da biblioteca como palco da dissertação, encenando LVME e BP, Perec e Flaubert e diversos outros coadjuvantes.

Por sua vez, procurei também mostrar que Perec e Flaubert também são escritores que possuem uma relação especial com os livros, com os saberes e com as coisas, pela forma como essa relação é revelada em suas práticas de leitura e escrita. Sem valorizar a funcionalidade dos objetos e a vinculação de um saber a uma aplicação específica, ambos compõem seus livros para que os leitores sejam, por um lado, espectadores do que acontecerá no palco das páginas, sobretudo em seus trechos descritivos.

No caso de Flaubert, a forma como fabrica imagens em suas descrições apontam para um aspecto novo no romance em sua época. De acordo com Gisèle Séginger (2000, p. 209), a representação flaubertiana "pinta, representa o mundo, mas para valorizar uma escrita, a virtuosidade de uma organização narrativa e um estilo”233. Na mesma esteira, Joëlle Gleize (1992) explica que à diferença dos narradores tradicionais, como os de Stendhal e Balzac, que guiam o leitor por meio de comentários e descrições, o narrador flaubertiano faz o possível

\footnotetext{
233 “L’oeuvre sera avant tout une présentation d’écriture, un livre fait de phrase, de mots, de sons. Dans la Correspondance le double registre de métaphores picturales et musicales témoigne du paradoxe de la représentation flaubertienne: elle peint, elle représente le monde mais pour mettre en valeur une écriture, la virtuosité d'une organisation narrative et d'un style."
} 
para se ausentar e constrói imagens que nem sempre apresentam um referencial palpável ao leitor. Além disso, em Flaubert, os livros e os discursos são somados, usados por todos, citados por todos e em diversas ocasiões. Quanto mais o narrador representa, soma, mostra, mais o objeto e o saber desaparecem, pois “o essencial não é o que é visto, nem aquele que vê, mas a forma de ver, o olhar" ${ }^{234}$. Por isso, apesar de o narrador flaubertiano não ensinar nada sobre o mundo, ele "prepara” ou anuncia um novo leitor, que precisa ter um outro olhar sobre esse "caleidoscópico de conhecimentos rudimentares”235, no caso de BP. Esse apagamento da figura do narrador por meio dessas práticas de escrita ligadas ao acúmulo de discursos alheios sem a possibilidade de síntese demonstra que o livro não é exclusivo daquele que assina a capa, “mas [é] de toda uma cadeia de instâncias e de instituições em que o leitor encontra, conquista seu lugar"236.

A questão do olhar também é muito presente em Perec. Basta lembrar a epígrafe de Júlio Verne presente em LVME: “Olhe bem com seus olhos, olhe”237. Ao longo do(s) romance(s), o narrador perecquiano nos convida, a princípio, a olhar o que há nos apartamentos, propondo que nós mesmos também olhemos as coisas com um outro olhar, talvez nos perguntando de forma semelhante ao escritor: "Parece-me que me coloco uma questão muito simples: como olhar? Como parar começar a ver nas coisas outra coisa que o que me habituaram a ver. [...] As coisas sendo o que elas são, dizemos, mas as coisas nunca são assim, resta uma margem” ${ }^{238}$. Assim, olhamos, não sem alguma estranheza, o apartamento vazio de Winckler e a loja de antiguidades de Mme. Marcia. Mais uma vez, em LVME, o narrador se distancia para dar espaço, desta vez, não apenas ao cientificismo, ao questionamento da erudição, mas às coisas banais, às reproduções de livros, cartazes, bulas, receitas, e também às citações, às armadilhas dos livros dentro de livros das quais não conseguimos nos desvencilhar por completo. Em Perec, estamos diante de algo semelhante ao que Gleize (1992, p. 250) sintetiza na ficção de Ítalo Calvino:

\footnotetext{
234 “L'essentiel n’est pas ce qui est vu, ni celui qui voit, mais la façon de voir, le regard, ce que Flaubert appelle aussi 'la conception', ou encore la pensée - qu'il ne faut pas confondre avec les opinions” (SÉGINGER, 2000, p. 209)

235 “Ce kaléidoscope de connaissances rudimentaires [...]”. Expressão utilizada por Nathalie Sarraute (1986, p. 85), no ensaio "Flaubert le précurseur".

236 “Le livre n'est plus seulement l'oeuvre de son auteur, mais de toute une chaine d'instances et d'institutions où le lecteur trouve, conquiert sa place.” (GLEIZE, 1992, p. 256)

237 "Regarde de tous tes yeux, regarde (Jules Verne, Michel Strogoff)" (LVME, p. 15)

238 "Il me semble que je me pose une questin très simple: comment regarder ? Comment cesser commencer de voir dans les choses autre chose que ce que l'on m'a habitué à voir. [...] Les choses étant ce qu'elles sont, dit-on, mais les choses ne sont jamais ainsi, il reste une marge." (tap. $\mathrm{f}^{0}$ 119,21,28,5 daté du "8 avril 1962" apud HARTJE, 1995, p. 40)
} 
À construção dessa armadilha contribui fortemente a reflexividade generalizada que transforma o universo fictício do romance em um caleidoscópio, em uma "máquina catóptrica" ou nesse "teatro polidíptico" cujo narrador de Em uma rede de linha entrecruzadas projeta reconstituir "a sessentena de pequenos espelhos que forram o interior". ${ }^{239}$

Assim como o romance, vimos que a biblioteca como modo de ler em relação também possui uma qualidade caleidoscópica, ou seja, oferece, àquele que olha fixamente o mesmo objeto e apenas empreende um movimento que altera o ângulo e a disposição dos elementos desse artefato óptico, a reflexão de diversas imagens, as quais podem refletir inclusive alguns dos aspectos mais secretos do próprio observador.

No entanto, é preciso dizer neste último passo suspenso, o artefato óptico utilizado em minha releitura de $L V M E$ e $B P$ não depende exclusivamente do reflexo da luz exterior, já que está sendo empregado no "escuro do presente" e procura refazer, de outros modos, a pergunta que já foi feita por Flaubert e Perec em seus respectivos contextos: por que olhar esses livrosbibliotecas hoje? Como olhar as coisas, as informações e a literatura após desempacotar esses livros no escuro deste tempo? É como escuro que Agamben (2009, p. 72) define o contemporâneo:

\begin{abstract}
[...] o contemporâneo não é apenas aquele que, percebendo o escuro do presente, nele apreende a resoluta luz; é também aquele que, dividindo e interpolando o tempo, está à altura de transformá-lo e de colocá-lo em relação com os outros tempos, de nele ler de modo inédito a história, de "citá-la" segundo uma necessidade que não provém de maneira nenhuma do seu arbítrio, mas de uma exigência à qual ele não pode responder.
\end{abstract}

Mantendo o olhar fixo na escuridão de seu tempo, Ítalo Calvino (1990) partiu do questionamento sobre o destino da literatura numa era tecnológica pós-industrial e propôs, em 1985, seis lições para o milênio em que estamos, a saber: leveza, rapidez, exatidão, visibilidade, multiplicidade e consistência. Para interpelar a literatura "na perspectiva do novo milênio”240, Calvino compõe ensaios que apresentam uma releitura da literatura a partir de temas, passeia pelos tempos e comenta escritores clássicos, românticos, modernos,

\footnotetext{
239 “À la construction de ce piège contribue fortement la réflexivité géneralisée qui transforme l’univers fictif du roman en un kaléidoscope, en une 'machine catoptrique' ou en ce 'théatre polydistyque' dont le narrateur de Dans un réseau de lignes entrecroisées projette de reconstituer 'la soixantaine de petits miroirs qui tapissent l'intérieur'."

${ }^{240}$ Calvino (1990, p.11) apresenta o objetivo de suas lições americanas: "Minha confiança no futuro da literatura consiste em saber que há coisas que só a literatura com seus meios específicos nos pode dar. Quero pois dedicar estas conferências a alguns valores ou qualidades ou especificidades da literatura que me são particularmente caros, buscando situá-los na perspectiva do novo milênio.”
} 
contemporâneos, etc., mostrando como sua relação com seu tempo ${ }^{241}$ é permeada pela literatura. Dessa forma, ele se revela um contemporâneo, conforme a definição de Agamben (2010, p. 59), pois: “A contemporaneidade, portanto, é uma singular relação com o próprio tempo, que adere a este e, ao mesmo tempo, dele toma distâncias; mais precisamente, essa é $a$ relação com o tempo que a este adere através de uma dissociação e um anacronismo.”

$O$ romance inacabado de Flaubert, $B P$, aparece como o paradigma dos romances que reúnem o aspecto da Multiplicidade em vários pontos. Relembro novamente essa lição, pois Calvino (1990, p. 121) inicia essa conferência sobre a multiplicidade tratando do "romance contemporâneo como enciclopédia, como método de conhecimento, e principalmente como rede de conexões entre os fatos, entre as pessoas, entre as coisas do mundo”. Acredito que seja por esse aspecto que Flaubert e Perec permaneçam tão atuais e sejam continuamente relidos; assim como a enciclopédia, o romance sofreu o impacto da revolução da informação, abandonando a ambição de dar conta da totalidade de saberes e coisas do mundo em um único tomo, além de renunciar à totalidade da existência de uma vida para assumir, ao longo do século XX, a mobilidade de espaços e tempos, a multiplicidade de personagens e de saberes e, com isso, aumentar as possibilidades de leitura. Finalmente, a multiplicidade é a característica que define não só esses livros-bibliotecas e o modo de ler aqui proposto, mas a própria vida na contemporaneidade, afinal “[...] que somos nós, quem é cada um de nós senão uma combinatória de experiências, de informações, de leituras, de imaginações? Cada vida é uma enciclopédia, uma biblioteca, um inventário de objetos, uma amostragem de estilos, onde tudo pode ser continuamente remexido e reordenado de todas as maneiras possíveis.”? (CALVINO, 1990, p. 138)

${ }^{241}$ Não é à toa que inicia a apresentação das Lições com a frase "Estamos em 1985 [...]” (CALVINO, 1990, p. 11) 


\section{Bibliografia}

AGAMBEN, G. O que é o contemporâneo? e outros ensaios. trad. Vinícius Nicastro Honesko. $2^{\mathrm{a}}$ reimp. Chapecó, SC: Argos, 2010.

ALTER, R. Flaubert: The demise of the spectator; Flaubert: Urban Poetics. In: Imagined Cities - urban experience and the language of the novel. Londres: Yale Univ. Press, 2005. p.1-42.

ARAUJO, R. L. André Gide e Georges Perec: os diálogos potenciais. 2008. Dissertação (Mestrado em Língua e Literatura Francesa) - Faculdade de Filosofia, Letras e Ciências Humanas, Universidade de São Paulo, São Paulo, 2008.

ASSOCIATION GEORGES PEREC. CATALOGUE de la bibliothèque personnelle de Georges Perec. Disponível em: < http://associationgeorgesperec.fr/IMG/pdf/Catalogue_BGPemail.pdf $>$. Acesso em 04 jan. 2012.

AUERBACH, E. Na Mansão de la Mole. In: Mimesis - a Representação da Realidade na Literatura Ocidental. São Paulo: Perspectiva, 2007, p. 405-441.

BACHELARD, G. Introduction. In: La poétique de l'espace. 5a. ed. Paris: Presses Universitaires de France, 1992, p. 1-21.

BARBOSA, J. A. A Biblioteca Imaginária. São Paulo: Ateliê, 1996.

BARTHES, R. Arcimboldo ou retórico e mágico. In: O óbvio e o obtuso. Trad. Léa Novaes. Rio de Janeiro: Nova Fronteira, 1990.

Crítica e Verdade. São Paulo: Perspectiva, 2003.

La préparation du roman - Cours et séminaires au Collège de France. Tome 2 (1979-1980). Paris: Seuil, 2003.

1972.

Le Degré zéro de l'écriture - suivi de Nouveaux Essais Critiques. Paris: Seuil, . L'effet de réel. In: Oeuvres Complètes III - 1968-1971. Paris: Seuil, 2002, p.2532. 
Mythologies. Paris: Seuil, 1957.

O grau zero da escritura. São Paulo: Cultrix, 1953.

O prazer do texto. São Paulo: Perspectiva, 1993.

BÉLANGER, D. Les modalités de réécriture chez Madeleine Ferron. 2002. Dissertação (mestrado) - Departamento de Língua e Literatura Francesa, Univ. McGill, Montréal, 2002.

BELLOS, D. Georges Perec: une vie dans les mots. Paris: Seuil, 1994.

BENJAMIN, W. Desempacotando minha biblioteca. In: Obras escolhidas II - Rua de mão única. São Paulo: Brasiliense, 1987. p. 227-235.

BERTHOMIER, M. Bibliothèques idéales. Paris, s.d. Não paginado. Compte rendu. Disponível em: <http://www.fabula.org/revue/cr/300.php>. Acesso em 20 jul. 2011.

BLOOM, H. A Angústia da Influência: uma teoria da poesia. Trad. A. Nestrovski. Rio de Janeiro: Imago, 1991.

BORGES, J. L. Ficções. Trad. Carlos Nejar. 3. ed. São Paulo: Globo, 2001.

2007.

Outras inquisições. Trad. Davi Arrigucci Jr. São Paulo: Companhia das Letras,

. Vindicación de Bouvard e Pécuchet. In: Obras completas 1923-1945. Buenos Aires: Emecé, 1989, p. 259-266.

BURGELIN, C. Perec lecteur de Flaubert. In: La Revue des Lettres Modernes - Gustave Flaubert. Paris, 1984, p. 135-171

BUTOR, M. Repertório. Trad. Leyla Perrone-Moisés. São Paulo: Perspectiva, 1974.

Cahier Georges Perec 6 - L’oeil, d’abord. Evreux: Seuil, 1996. 
CALVINO, I. Por que ler os clássicos? In: Por que ler os clássicos?. Trad. Nilson Moulin, São Paulo: Cia. das Letras, 2007.

Seis Propostas para o próximo milênio: lições americanas. Trad. Ivo Barroso. São Paulo: Companhia das Letras, 1990.

CNRS-LIRE. Les dossiers de Bouvard et Pécuchet. Projeto de edição e transcrição dos dossiês de Bouvard e Pécuchet sob a direção de Stéphanie Dord-Crouslé (CNRS, UMR 5611 LIRE - équipe ENS Lyon XIX ${ }^{\mathrm{e}}$ ). Disponível em: <http://dossiers-flaubert.ish-lyon.cnrs.fr/>. Acesso em julho. 2010.

COMPAGNON, A. O trabalho da citação. Trad. Cleonice P. B. Mourão. Belo Horizonte: UFMG, 2007.

CONSTANTIN, D. La Vie mode d'emploi de Georges Perec: le vestibule du 11, rue SimonCrubellier. In: Masques et mirages - Genèse du roman chez Cortázar, Perec et Villemaire. New York: Peter Lang, 2008, p.81-120.

D’Alembert, J. le R. Discours Préliminaire de l'Encyclopédie. Édition Wieleitner, 1911. Disponível em: <http://art-bin.com/art/oalembert.html>. Acesso em 03 jul. 2010.

DEBRAY-GENETTE, R. et al. Travail de Flaubert. Paris: Seuil, 1983.

DELAUNE, B. Un cas précis de "plagiat par anticipation": Antonin Artaud accuse Lewis Carroll. In: Acta Fabula, Dossier critique autour du Plagiat par anticipation. Disponível em: <http://www.fabula.org/revue/document4990.php>. Acesso em: 22 fev. 2012.

DRUMMOND DE ANDRADE, C. Lição de coisas. Rio de Janeiro: José Olympio, 1965.

ECO, U. A poética da obra aberta. In: Obra aberta. São Paulo: Perspectiva, 2005, p. 37-89.

Sobre a literatura. Trad. Eliana Aguiar. Rio de Janeiro: Record, 2003.

The infinity of lists. New York: Rizzoli, 2009.

ELIOT, T. S. A tradição e o talento individual. In: Ensaios de Doutrina Crítica. Lisboa: Guimarães Editores, p. 21-32. 
FERRER, D.; D’IORIO, P. (dirs.). Bibliothèques d'écrivains. Paris: CNRS Editions, 2001.

FLAUBert, G. Bouvard et Pécuchet. Édition d’Alberto Cento précédée des scénarios inédits. Napoli ; Istituto Universitario Orientale ; Paris; A-G. Nizet, 1964. [Consulta aos roteiros inéditos]

. (1881) Bouvard et Pécuchet. Édition de Claudine Gothot-Mersch. Paris: Gallimard: Folio Classique, 2009. [Todos os trechos citados neste trabalho são desta edição]

Bouvard et Pécuchet. Édition de Pierre-Marc de Biasi. Paris: Librairie Générale de la France; Le Livre de Poche. 1999. [Consulta ao prefácio "La Galaxie Bouvard et Pécuchet" (p. 7-26) e ao Dossiê, sobretudo, ao Article de Guy de Maupassant paru dans Le Gaulois du 6 avril 1881 (p. 469-474)]

2007.

Bouvard e Pécuchet. Trad. Marina Appenzeller. São Paulo: Estação Liberdade,

. Correspondance - Cinquième Série. Paris: Louis Conard, 1930.

Correspondance (1869 - 1972),vol 6. Paris: Louis Conard, 1930.

L’Éducation sentimentale. Paris: Pocket Classiques, 1998a.

Lettres
Édition électronique par Danielle Girard et Yvan Leclerc (Université de Rouen). Disponível em: <http://flaubert.univ-rouen.fr/index.php>. Acesso em julho de 2010. [Todos os trechos citados neste trabalho são desta edição]

Madame Bovary. Paris: Pocket Classiques, 1998b.

Un grand carnet d'idées: le carnet 15 (1869-1974?). In: Carnets de travail. Éd. Pierre-Marc de Biasi. Paris: Balland, 1988, p. 460-530.

FOUCAULT, M. Posfácio a Flaubert (A tentação de Santo Antão). In: MOTTA, Manoel B. da. (org.) Ditos e escritos. vol. III. Trad. Inês A. D. Barbosa. Rio Grande do Sul: Forense Universitária, 2006, p. 75-101. 
FUX, J. A matemática em Georges Perec e Jorge Luis Borges: um estudo comparativo. 2010. 249 p. Tese (Doutorado em Literatura Comparada) - Universidade Federal de Minas Gerais, Belo Horizonte, 2010.2 Disponível em: <http://www.bibliotecadigital.ufmg.br/dspace/bitstream/1843/ECAP-8BQF7G/1/tesefinal201 0revisada.pdf>. Acesso em 11 nov. 2011.

GALÍNDEZ-JORGE, V. Fogos de artifício - Flaubert e a escritura. São Paulo: Ateliê Editorial, 2009.

GAMA, M. R. Sobre o que não deveu caber - repetição e diferença na produção e recepção de Tutaméia. 2008. 187 p. Dissertação (Mestrado em Língua e Literatura Francesa) - Faculdade de Filosofia, Letras e Ciências Humanas, Universidade de São Paulo, São Paulo, 2008.

GENETTE, G. Discours du récit. In: Figures III. Paris: Seuil, 1972, p.67-268.

Gérard Genette devant ses machines à vertige: interview with Patrick Redelberg. In:

Art Press, Paris, v. 68, p. 30-33, mars 1983.

. Palimpsestes - La Littérature au Second Degré. Paris: Seuil, 1982.

Silences de Flaubert. In: Figures I. Paris: Seuil, 1966, p.223-43.

GENGEMBRE, G. Les grands courants de la critique littéraire. Paris : Seuil, 1996.

GIGNOUX, Anne-Claire. De l'intertextualité à la récriture. In: Cahiers de Narratologie. Paris, n.13, Não Paginado, 2006. Disponível em: <http://revel.unice.fr/cnarra/index.html?id=329> Acesso em: 02. Out. 2006.

La récriture: formes, enjeux, valeurs. Paris: Presses de l'Université de ParisSorbonne, 2003.

GLEIZE, J. Le Double miroir - le livre dans les livres de Stendhal à Proust. Paris: Hachette Supérieur, 1992.

HAMON, P. Du descriptif. Paris: Hachette Supérieur, 1993. 
HARTJE, H. Georges Perec écrivant. Tese sob a orientação de Jacques Neefs. Université Paris VII, 1995.

HAY, L. (org.) Carnets d'écrivains - Hugo, Flaubert, Proust, Valéry, Gide, du Bouchet, Pérec. Paris: Éditions du CNRS, 1990. p. 7-56 e 202-253.

HUTCHEON, L. Poética do Pós-Modernismo: história, teoria, ficção. Trad. Ricardo Cruz, Rio de Janeiro: Imago Ed., 1991.

IELPO, R. S. Perec e o esgotamento da história. 2010. Tese (Doutorado em Estudos Literários Neolatinos) - Université Paris Diderot (Paris 7) e Universidade Federal do Rio de Janeiro, Rio de Janeiro, 2010.

KRISTEVA, J. Séméiotikè - Recherches pour une sémanalyse. Paris: Éditions du Seuil, 1969, p.82-112.

LANDOW, G. Hypertext: The Convergence of Contemporary Critical Theory and Technology. Baltimore e London: The John Hopkins University Press, 1992.

LANSON, G. La méthode de l'Histoire Littéraire; La fonction des influences étrangères dans le développement de la littérature française; Sur la notion d'influence. In: Essais de méthode de critique et d'histoire littéraire. Edited by Henri Peyre. Paris: Hachette, 1965, p. 31-56.

LECLERC, Y. (dir.) La Bibliothèque de Flaubert: inventaires et critiques. Rouen: Publications de L'Université de Rouen, 2001.

LÉVI-STRAUSS, C. The savage mind. Chicago: The Univ. of Chicago Press, 1966.

LOPEZ, T. A. A criação literária na biblioteca do escritor. Ciência e Cultura, São Paulo, vol. 59, n.1. p. 33-37, jan./mar. 2007.

MACIEL, M. E. A memória das coisas. Rio de Janeiro: Lamparina Editora, 2004.

As ironias da ordem - Coleções, inventários e enciclopédias ficcionais. Belo Horizonte: Editora UFMG, 2009. jun. 2007.

Poéticas do Inclassificável. Revista Aletria, Belo Horizonte, v. 15, p. 155-162, jan- 
Magazine Littéraire. L'univers des bibliothèques - d'Alexandrie à Internet. N. 349. Paris: Presses Universitaires de France, p. 16-66, déc. 1996.

MANGUEL, A. A biblioteca à noite. Trad. Samuel Titan Jr. São Paulo: Cia. das Letras, 2006.

MAUREL-INDART, H. Le précurseur dépossédé. 2009. In: Acta Fabula - Dossier critique autour du Plagiat par anticipation. Disponível em: <http://www.fabula.org/revue/document4889.php>. Acesso em 23 fev. 2012.

MIGUET, M. Sentiments filiaux d'un prétendu parricide. In : Poétique, n.o. 54, Paris: Seuil, 1983.p.135-47.

MINDLIN, J. Loucura Mansa. In: A paixão pelos livros. 2. reimp. Rio de Janeiro: Casa da Palavra, 2004, p.15-16

MOUREY, J-P. Philosophies et pratiques du détail. Seussel: Champ Vallon, 1996.

MURAD, S. A peça flaubertiana no Les choses de Georges Perec. Trabalho apresentado na disciplina “A ficção de Gustave Flaubert”, ministrada pelo Prof. Dr. Samuel Titan Jr. em agosto de 2008.

Le voyage d'hiver de Georges Perec ou a máquina de contar histórias: leitura e potencialidade, leitura como potencialidade. 2007. 146p. Dissertação (Mestrado em Língua e Literatura Francesa) - Faculdade de Filosofia, Letras e Ciências Humanas, Universidade de São Paulo, São Paulo, 2007. Disponível em: <http://www.teses.usp.br/teses/disponiveis/8/8146/tde-06112007-115044/>. Acesso em: 24 fev. 2012.

Sobre a leitura de À la recherche du temps perdu. 2012. Tese (Doutorado em estudos Linguísticos, Literários e Tradutológicos em Francês). Faculdade de Filosofia, Letras e Ciências Humanas, Universidade de São Paulo, São Paulo, 2012.

NEEFS, J.; DIDIER, B. Penser, Classer, Écrire - de Pascal à Perec. Saint-Dennis: Presse Universitaire de Vincennes, 1990.

OULIPO, La littérature Potentielle (Créations, Re-Créations, Récréations). Paris: Gallimard, 2003. 
La bibliothèque Oulipienne. Paris: Le Castor Astral, 1997. vol. 4.

PEREC, G. A coleção particular. Trad. Ivo Barroso. São Paulo: Cosac Naify, 2005.

À propos de la description. In: RENIER, A. Espace \& Représentation. Paris: Les éditions de la Villete, 1982, p. 325-346.

A vida modo de usar. Trad. Ivo Barroso. São Paulo: Companhia das Letras, 2009.

Cahiers de charges de La Vie mode d'emploi. Paris: Zulma-CNRS, 1993.

Entretiens et conférences (1965-1978). Édition critique établie par Dominique Bertelli et Mireille Ribière. Paris: Joseph K, 2003a. v. 1.

Entretiens et conférences (1979-1981). Édition critique établie par Dominique Bertelli et Mireille Ribière. Paris: Joseph K, 2003b. v. 2.

Espèces d'espaces. Paris: Galilée, 1974.

. La Vie mode d'emploi. Paris: Hachette, 1994.

Les Choses - une histoire des années soixante. Paris: Denoël, 2005.

Le voyage d'hiver. Paris: Seuil, 1993.

. L. G. - une aventure des années soixante. Paris: Seuil, 1992.

. Penser/Classer. Paris: Hachette, 1985.

Quel petit vélo nomé au fond de la cour? Paris: Gallimard, 1966.

. Un cabinet d'amateur. Paris: Balland, 1988.

. Un homme qui dort. Paris: Denoël, 1969. 
PERRONE-MOISÉS, L. Texto, crítica, escritura. São Paulo: Ática, 1978.

PINO, C. C. A. A ficção da escrita. Cotia, SP: Ateliê Editorial, 2004.

.(org.) Criação em debate. São Paulo: Humanitas, 2007.

Flaubert e a escritura. 2002. p. 1-7. Ensaio disponível em:

<http://br.geocities.com/camigopino/Flaubert.doc> Acesso em 03 jun. 2009.

; ZULAR, R. Escrever sobre escrever: uma introdução à crítica genética. São

Paulo: WMF Martins Fontes, 2007.

POULET, G. La Conscience Critique. Paris: Librairie José Corti, 1971.

PROUST, M. A propos du 'style' de Flaubert. Disponível em: $<$ http://perso.wanadoo.fr/jb.guinot/pages/Proust.html>. Acesso em 30 nov. 2005.

QUENEAU, R. Bouvard et Pécuchet de Gustave Flaubert. In: Bâtons, chiffres et lettres. Paris: Gallimard, 1985. p.97-124

RABELAIS, F. Gargantua. Paris: Pocket Classiques, 1998.

Pantagruel. Paris: Gallimard, 1964.

Revista Criação \& Crítica (Revista on-line). N. 6.Disponível em: $<$ http://www.fflch.usp.br/dlm/criacaoecritica/index.php?option=com_content\&view=article\&i d=152\&Itemid=99> 100p. Acesso em: $12 \mathrm{dez} .2011$.

Revue Arts et Savoirs. N. 1, 2012. Bouvard et Pécuchet: la fiction des savoir. Revista lançada pelo grupo LISAA (Littératures, Savoirs et Arts) sob coordenação de Gisèle Séginger. Disponível em: <http://lisaa.univ-mlv.fr/arts-et-savoirs/parution-du-numero-1-bouvard-etpecuchet-la-fiction-des-savoirs/> Acesso em 11 abr. 2012.

(Revue) Flaubert. N. 1, jan. 2009. Nouvelles recherches critiques et génétiques. Sous la direction de Anne Herschberg-Pierrot. Revista on-line. Número lançado em 19 de janeiro de 2009. Disponível em: <http://flaubert.revues.org/index389.html>. Acesso em: 24 jun. 2009. 
Revue Flaubert. N. 4, 2004, Flaubert et les sciences. Numéro dirigé par Florence Vatan. Disponível em: <http://flaubert.univ-rouen.fr/revue/revue4/>. Acesso em: 06 abr. 2012.

Revue Flaubert. N. 11, 2011. Fictions du savoir, savoirs de la fiction dans Bouvard et Pécuchet. Numéro dirigé par Yvan Leclerc. Disponível em: <http://flaubert.univrouen.fr/revue/sommaire.php?id=12>. Acesso em: 06 abr. 2012. Não paginada.

RIBIÈRE, M. (org). Parcours Perec - Colloque de Londres (mars 1988). Lyon: Presses Universitaires de Lyon, 1990.

RICARDOU, J. La littérature comme critique. In: Pour une théorie du nouveau roman. Paris: Seuil, 1971, p.9-32.

Problèmes du nouveau roman. Paris: Seuil, 1967.

RICHARDS, I. A. Princípios de Crítica Literária. Porto Alegre: Globo, 1971.

RICOEUR, P. La configuration du temps dans le récit de fiction. Paris: Seuil, 1984. (Temps et Récit II)

RIFFATERRE, M. L'intertexte inconnu. In: Littérature, n. 41, p. 4-7, 1981. Intertextualité et roman en France, au Moyen Âge. Disponível em: <http://www.persee.fr/web/revues/home/prescript/article/litt_0047-4800_1981_num_41_1_ 1330> Acesso em 16 fev. 2012.

RIOU, D. Les bibliothèques de Georges Perec ou le mal d'archive. In: NEDELEC, C. (dir.) Les bibliothèques entre imaginaires et réalités. Arras: Artois Presses Université, 2009, p. 461-472.

SAMOYAULT, T. A intertextualidade. Trad. Sandra Nitrini. São Paulo: Aderaldo \& Rothschild, 2008.

SÁNCHEZ, Pablo Martín. Hypertextualité et pseudo-hypertextualité dans l'oeuvre de Georges Perec. In: Le Cabinet d'amateur. Revue d'études perecquiennes. (juillet 2011). p.1-12. Disponível em: <http://associationgeorgesperec.fr/IMG/pdf/PMartin.pdf> Acesso em 27 fev. 2012.

SARRAUTE, N. Flaubert le précurseur. In: Paul Valéry et l'Enfant d'Éléphant et Flaubert le précurseur. Paris: Gallimard, 1996, p. 59-89 
L'ère du soupçon. Folio Essais. Paris: Gallimard, 1956.

SCHOEPS, Luciana A. A ficcionalização do literário nas bibliotecas fantásticas de Gustave Flaubert e Machado de Assis. In: Revista Manuscrítica. São Paulo, no. 20, p. 143-167, 2011.

Bibliotecas fantásticas em chamas: Machado de Assis e Gustave Flaubert. 2012. Dissertação (Mestrado em Estudos Linguísticos, Literários e Tradutológicos em Francês). Faculdade de Filosofia, Letras e Ciências Humanas, Universidade de São Paulo, São Paulo, 2012. (Em andamento)

SCHUEREWEGEN, F. Joëlle Gleize, Le Double Miroir: le livre dans le livre, de Stendhal à Proust. In: Romantisme, n. 85, p. 125, 1994. Disponível. em: $<$ http://www.persee.fr/web/revues/home/prescript/article/roman_0048-8593_1994_num_ 24_85_6256>. Acesso em 06 abr. 2012.

SÉGINGER, G. Flaubert: une éthique de l'art pur. Paris: Sedes, 2000.

SHELLY, C. Pigault-Lebrun: tonner contre! Les mauvaises lectures de Flaubert. In: Littérature, n. 131, p. 18-36, 2003. Masques, intertextes. Disponível em: <http://www.persee.fr/web/revues/home/prescript/article/litt_0047-4800_2003_num _131_3_1806>. Acesso em 13 jan. 2012

SPERANZINI, M. M. A pesquisa infinita das coisas. 206p. Tese (Doutorado). - Faculdade de Filosofia, Letras e Ciências Humanas, Universidade de São Paulo. São Paulo, 2011.

STAROBINSKI, J. As máscaras da civilização: ensaios. Trad. Maria Lúcia Machado. São Paulo: Cia das Letras, 2001a. 2001b.

La relation critique: l'œil vivant II. Édition revue et augmentée. Paris: Gallimard,

SUGAYA, N. Le roman comme mode d'interrogation critique. In: Flaubert épistemologue. Amsterdan e New York: Rodopi, 2010. p.7-17.

TADIÉ, J-Y. La critique littéraire au $\mathbf{X X}^{\mathbf{e}}$ siècle. Paris: Belfond, 1987.

TASSEL, A. (org.) Cahiers de Narratologie, n. 13, sep. 2006. Nouvelles Approches de l'intertextualité. Disponível em: <http://revel.unice.fr/cnarra/> . Acesso em 04 out. 2006. 
TODOROV, T. Mikhaïl Bakhtine: le principe dialogique suivi de Écrits du Cercle de Bakhtine. Paris: Éditions du Seuil, 1981. p.95-115.

La Littérature en péril. Paris: Flammarion, 2006.

VARGAS LLOSA, M. A orgia perpétua - Flaubert e Madame Bovary. Rio de Janeiro: Francisco Alves, 1979. 